\title{
بنية قصيدة الإبيجرام في لافتات أحمد مطر
}

\author{
إعداد \\ د. أسماء محمود شمس الدين \\ قسم اللغة العربية و آدابها و اللغات الثرقية و آدابها \\ كلية الآداب ـ جامعة دمنهور
}

مجلة الدراسات التربوية والانسانية ــكلية التربية ـ جامعة دمنهور

المجلد السادس - العدد (3)- لسنة 2014 
بنية قصيدة الإبيجرام في لافتات أحمد مطرد. أسماء محمود شمس الدين 


\section{بنية قصيدة الإبيجرام في لافتات أحمد مطر}

د. أسماء محمود شمس الاين

\section{ملخص:}

أحمد مطر شاعر عراقي الموطن عربي الهوى، وحيد الغرض؛ إذ قصر

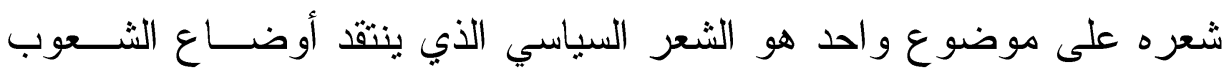

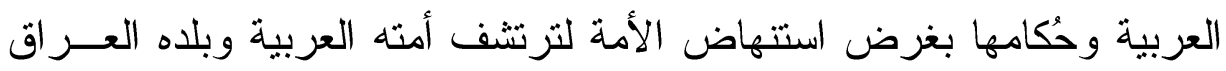

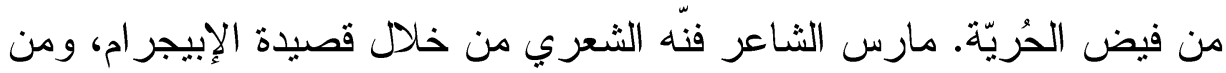

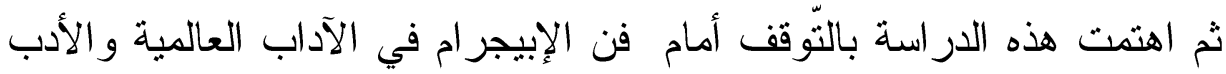
العربي قديمها وحديثها بصفة عامة.

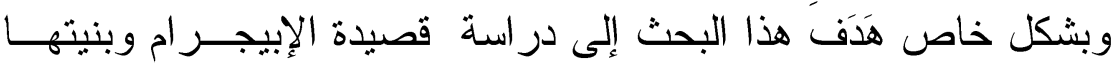

الفنبة عند الثاعر، وتوسل البحث إلى ذلك من خلال تتبع البنى المختلفة؛ بنية المفردات، و بنية التركيب،و بنية الدلالة،وبنية الإيقاع.

وتبيّن من و اقع در اسة فن الإبيجر ام في شعر أحمد مطر و لاففتاته أنه كانـــ

ثمة علامات مميزة عنده في هذا الجانب؛ منها:

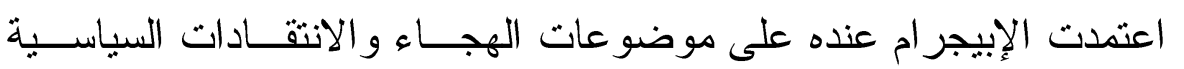

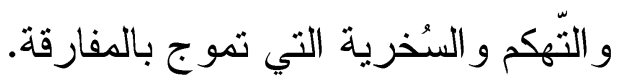

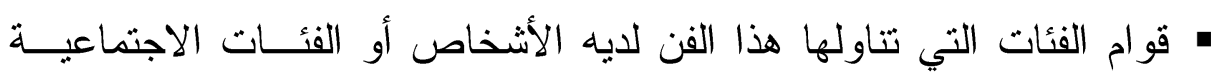

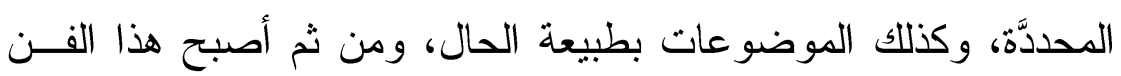

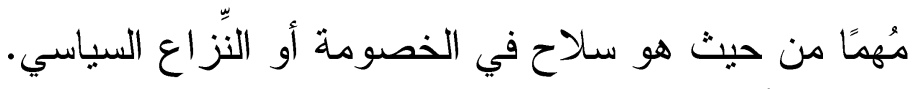

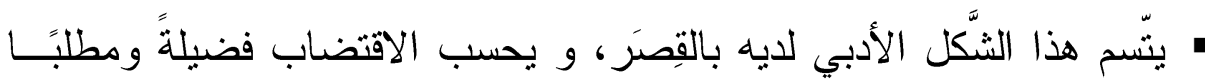

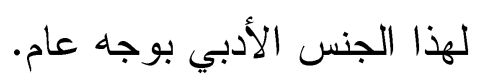

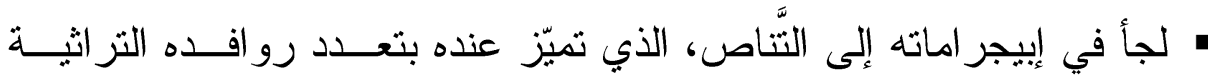

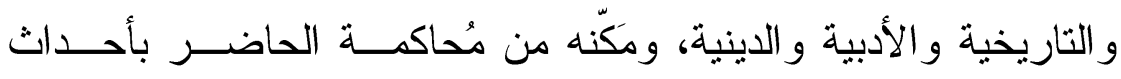

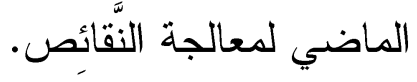


وقد تُضاف إلى الخصائص السابقة خصائص أخرى منها؛ أنه لا يتعين

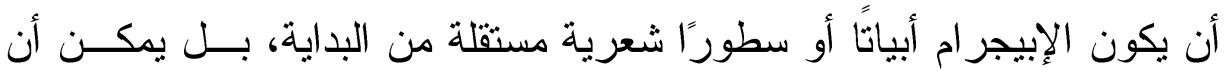

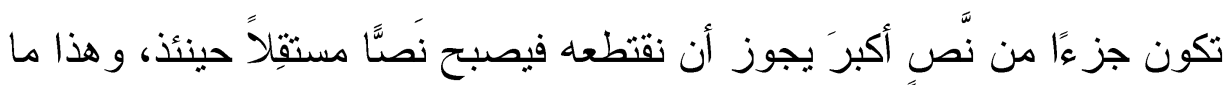
استدعى الحديث عن القصيدة القصيرة جدًا أو قصيدة الومضة. •احتلت المفارقة بأنو اعها لدى الشاعر بوصفها وحدة أسلوبية مكانة مهمة في إيبجر امه الشعري؛ فقدم النّص باعتباره"مفارقة موقف" تتجلّى من خلالها كافـــة

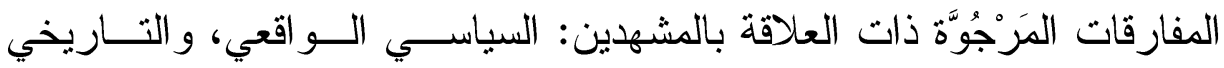

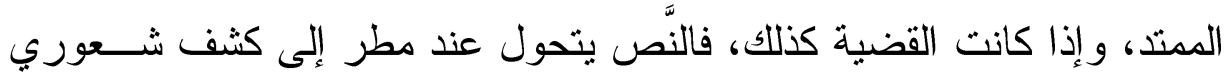

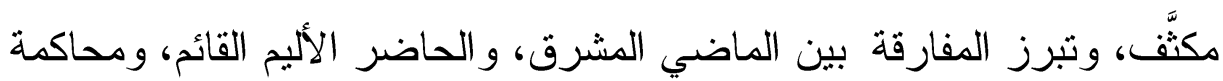
الو اقع العربي المُتردّي و التَّريض على التّنَّرد عليه و الدّفع إلى تغييره.

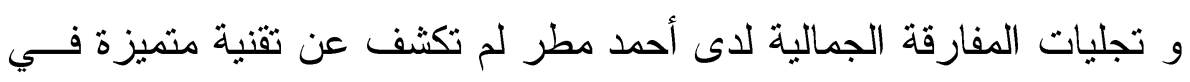

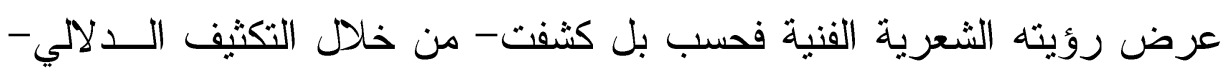

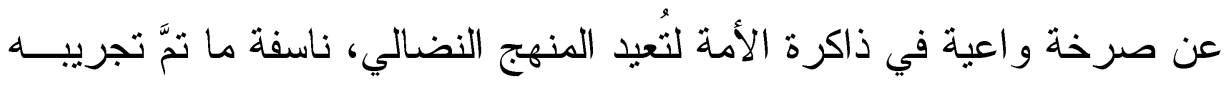
من زيف شعار اتي مهيض ومنكسر تلوكه الأمة منذ زمن دون جدوى.

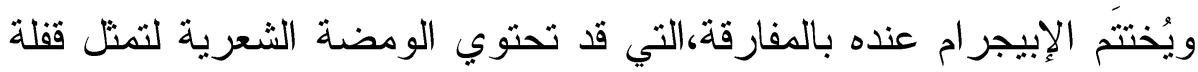

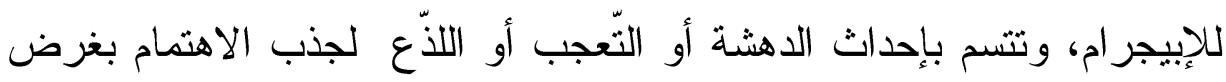

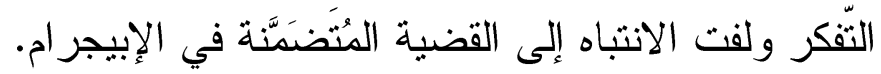

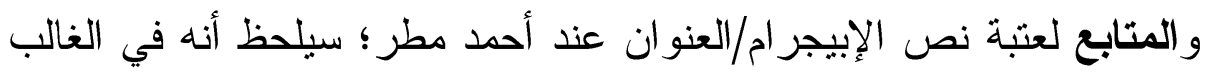

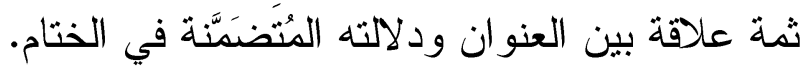

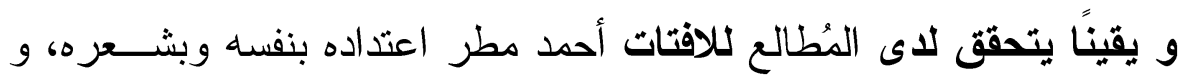

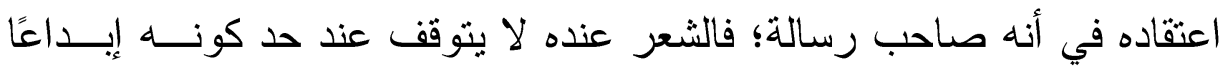
جماليًا بل الثعر رسالة إنسانية. 


\section{Abstract \\ The Artistic structure of Epigram in Ahmad Matar's "Lafitat"}

Ahmad Matar is an Iraqi poet who loves his Arabness and whose poetry centers around criticizing the conditions of the Arab peoples and Arab regimes in order to prompt the nation to seek freedom. Matar practised his poetic talent through the epigram. This study focuses on the epigram in world literature as well as in ancient and modern Arabic poetry.

The present research aims in particular to study the poetic epigram and its linguistic structure by examining the lexical, syntactic, semantic, and rhythmic structures in Ahmad Matar's poetry.

By examining Matar's poetic epigrams, a number of distinctive features can be discerned:

-Matar's epigrams are based on satire, political criticism, sarcasm, and paradoxical irony.

-Matar's poetic epigrams center around specific people or social groups and specific topics, making this art form a tool for political contention.

-This poetic form is characterized by shortness which is a requirement of such a literary genre.

- Matar resorts to intersexuality in his poetic epigrams by drawing upon historical, literary, and religious heritage in a way that allows him to judge the present in terms of the past and deal with the present shortcomings. In addition to the aforementioned features, it may be added that an epigram may not be an independent poetic unit but may rather be part of a larger text.

-Paradox as a stylistic element plays a significant role in Matar's poetic epigrams. The poetic text thus becomes a paradoxical situation through which all the paradox related to the political and historical scenes are revealed. Hence, Matar's poems become an intensely conscious revelation, the thing which highlights the discrepancy between a glorious past and a distressing present and allows the poet to judge the deteriorating status quo as well as incite people to change it.

Matar's epigrams conclude with a paradoxical statement that invites the reader to think about the issues raised by the epigrams. It can also be noticed that there usually exists a relation between the titles of Matar's epigrams and the meanings included in their conclusions. 


\section{مقدمة}

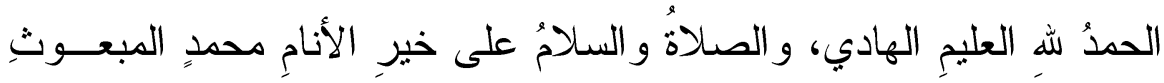

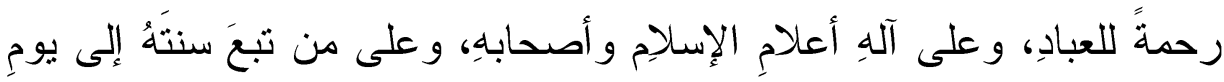
الدين، وبعد،

\section{الثاعر أحمد مطر:}

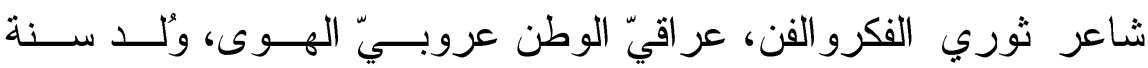

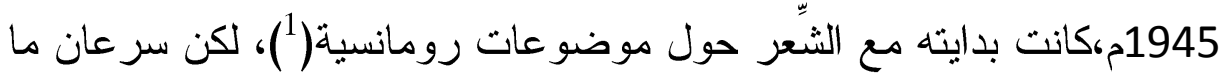

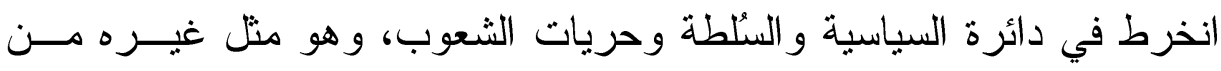

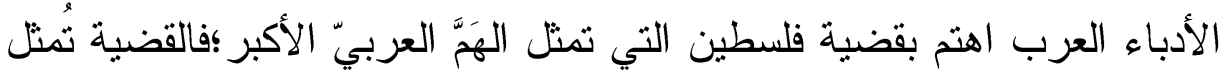
ـ على حد تعبيره _ازمن الدم الفلسطيني النازف)(2)، فشغلت الجانب الأكبر

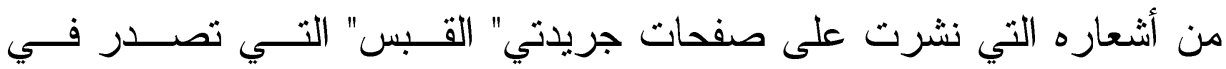

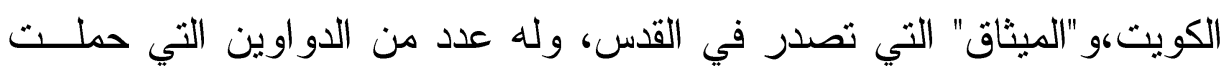
عنو ان" "لافتات"( ) (3)، و غير ها.

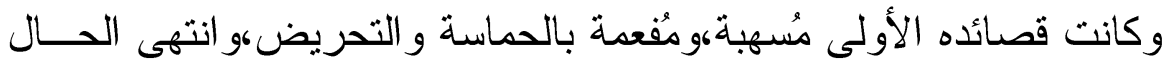

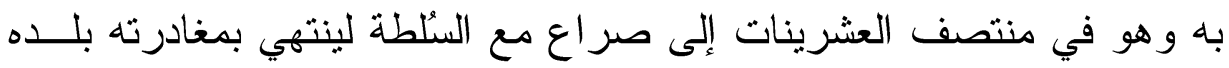
العراق إلى الكويت إثر مطاردة سلطات بلاده له، ولكن لم بطل المقام بالكويت

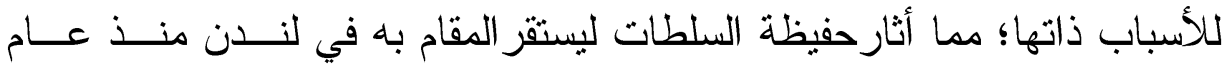

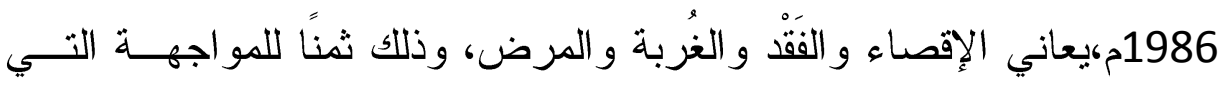

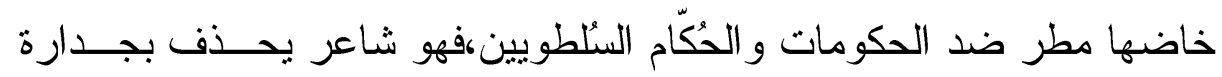
الفو اصل بين شعره وشخصيته، التي يلتقي فيها الثاعر و الإنسان في آن و احد

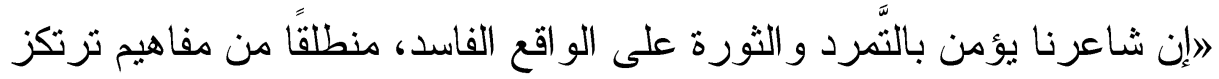

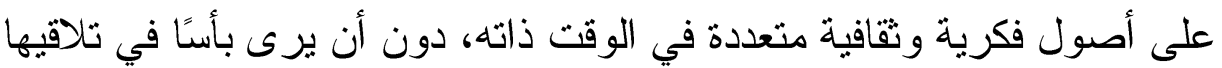

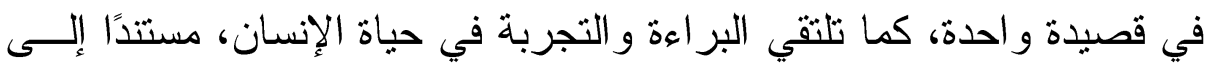

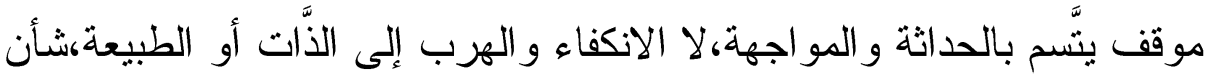


الشعر اء الآخرين.. وقد تأثر الثاعر بشكل واضح بالقرآن الكريم، حيث أكثر من التَّاهي مع نصوصهاه.(4) ،ومن إيبجر اماته في هذا السياق قوله:

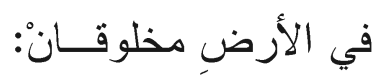

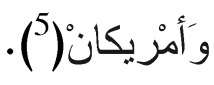

وقوله:خُّق المو اطن مُجرمًا حتى يُدان

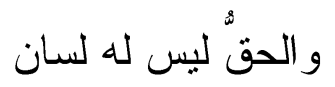

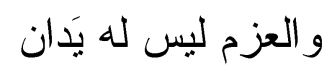

و السيف يُمسكه جبان لئن

وبدمعنا ودمائنا سقط الكيان

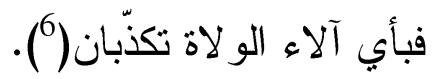

فأحمد مطر صوت شعريّ متميز على السيّاحتين العر اقية و العَربية، وله أثز

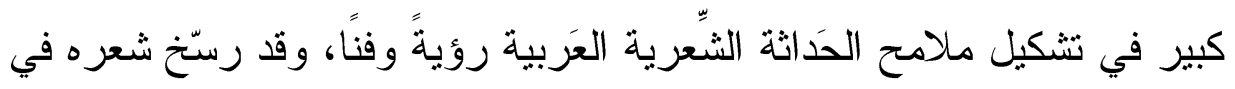

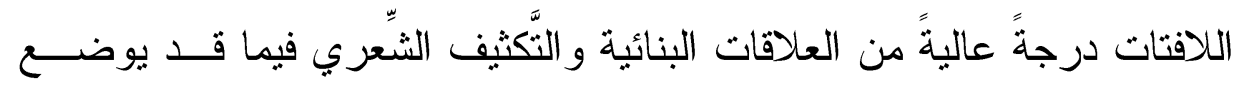

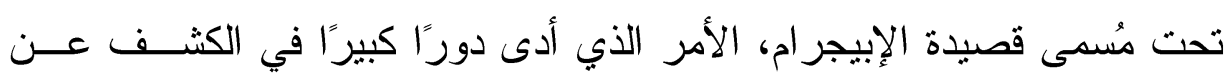

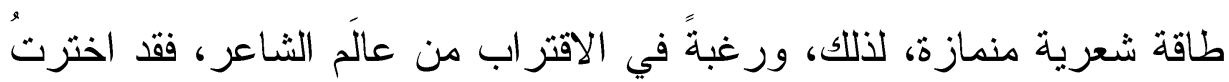

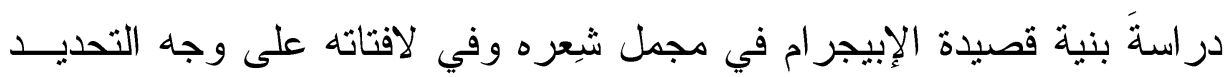
موضوعًا للار اسة،وسبب هذا الاختيار أمور منها:

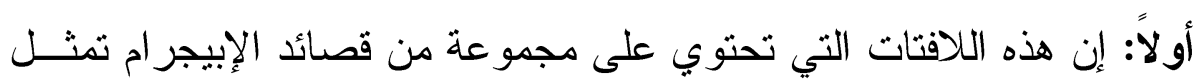

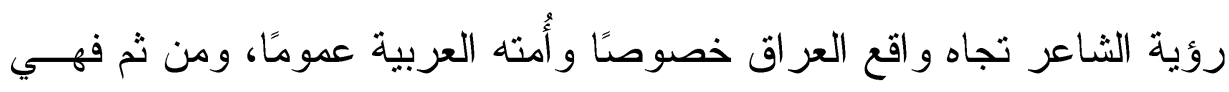

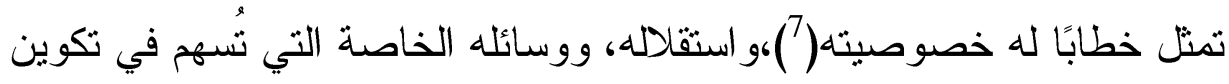

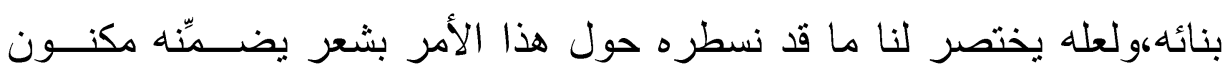

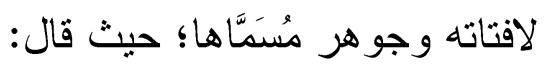
أنا لستُ إلا شاعرًا 


$$
\begin{aligned}
& \text { أبصرت نارَ العارِ } \\
& \text { ناشبةً بأرْديةِ الغُفاةْ } \\
& \text { فصرخت: هُبّو اللنّجاة. } \\
& \text { فإذا أَفاقو اللحياةِ } \\
& \text { ستَحْتَفِي بهم الحياةْ } \\
& \text { شِيعري عُصـارة عَصرِنا } \\
& \text { هَذي بذورُ حياتِنا }
\end{aligned}
$$

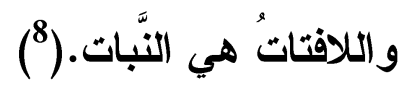

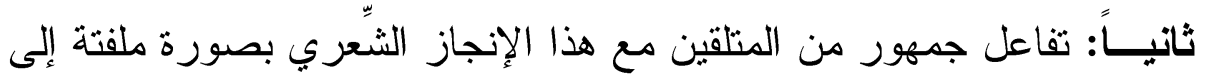

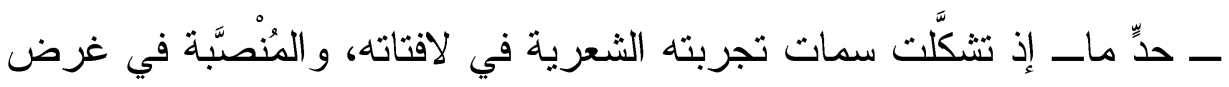
واحد، لهو أمر قد يُخري بالدر اسة. ثالثا: للثاعر العديد من اللافتات الثعرية(سبع لافتات)،ودر اسة بنية قصــيدة

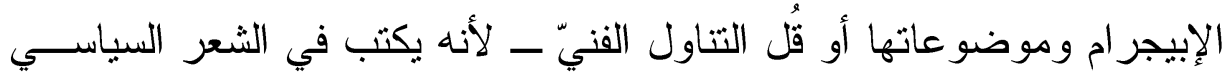

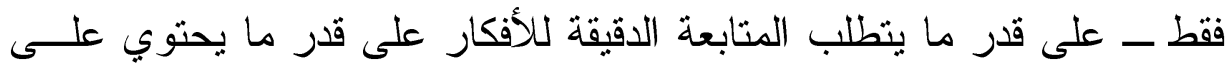

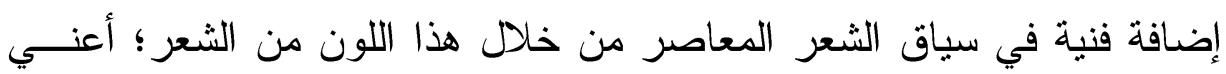

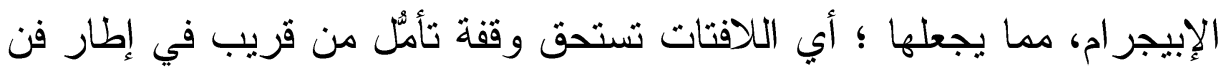

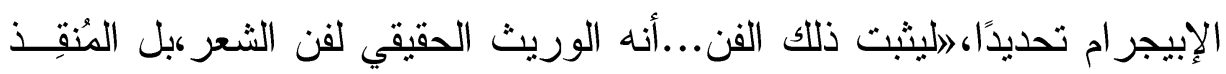

$$
\text { المطورّر له في قابل الأيامه( (َ). }
$$

وقد اعتمدت" المنهج الفني منهجًا لدراسة قصيدة الإبيجرام الم وملامحها الفنية في اللافتات، كما استعنت بأدوات من منهج البنيوية؛كونه يتيح المتابعة الدقيقة

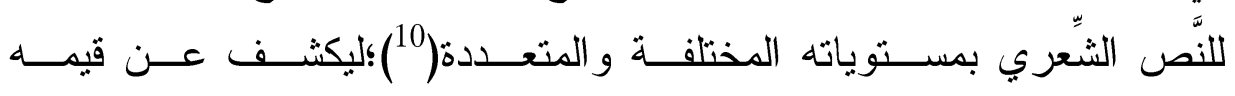

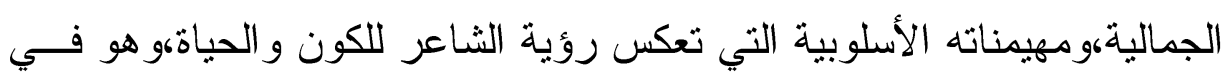

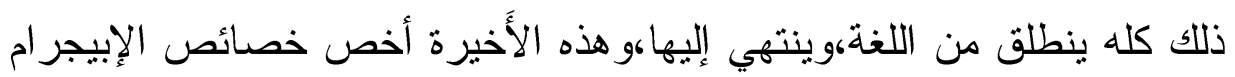


كما اقتضت طبيعة البحث الاستعانة بالمنهج التاريخي فـي تتبــع نشــأة فــن الإبيجز ام وتطوره.

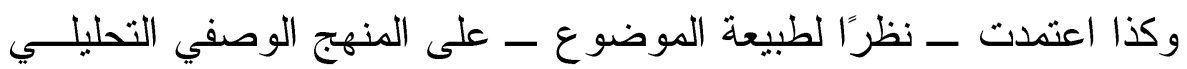

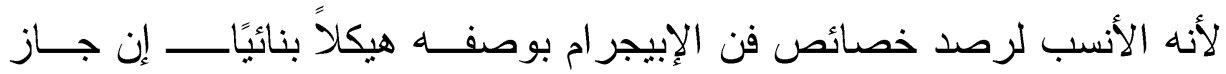

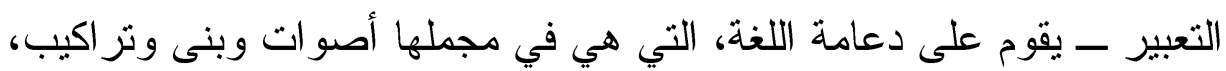

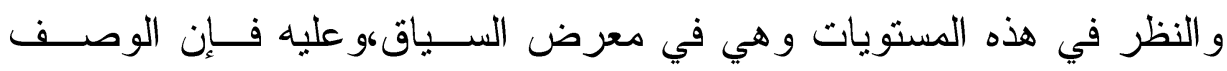

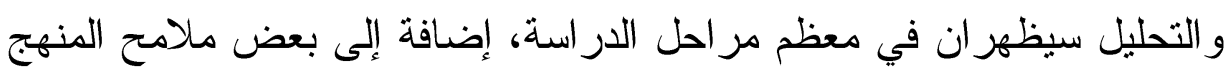

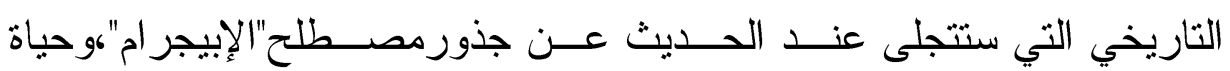

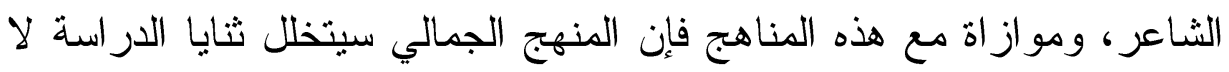

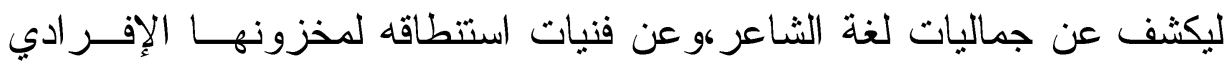

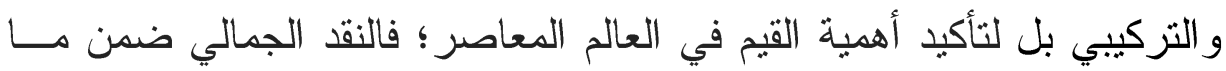

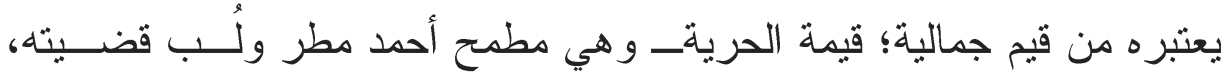
وكذا جميع القيم الأخلاقية و السياسية و الاجتماعية؛ فالجمال يمثل في المادة وفي وهي

$$
\text { الفكرة أو المضدون أيضًا (11). }
$$

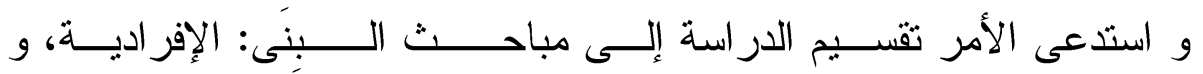
التركيبية، و الدلالة، و الإيقاع. . . و أخيرًا عرض و لنتائج الدراسة، ولإعاع. وثبت المصادر و المر اجع. 


\section{أولاً: إطلالة على فن الإبيحر ام في الآداب العالمبة قدبمها وحدبثها:}

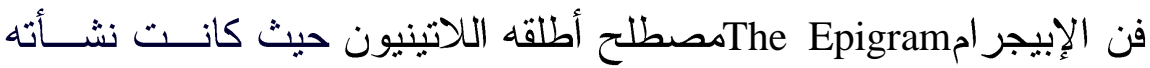
الأولى و عنو ا به النقش(12)؛ فقد كان القدماء ينقشون على قبور الموتى تخليــدًا

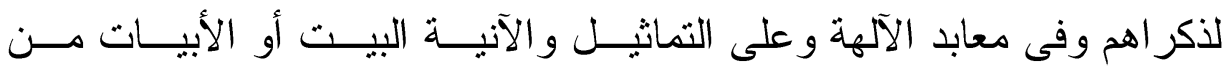

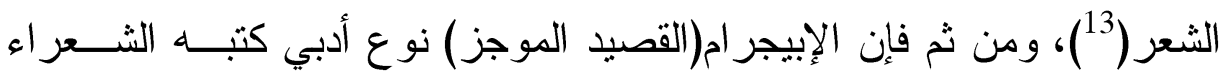

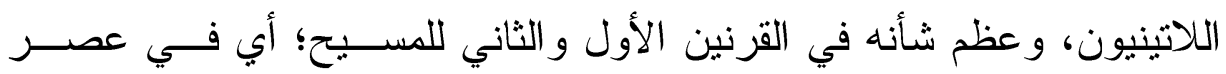

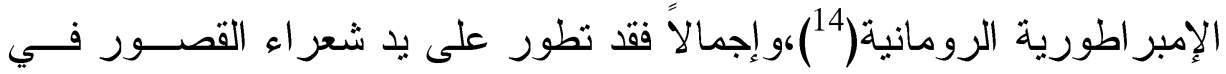

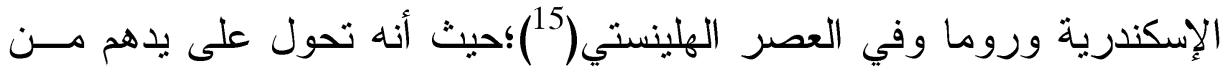

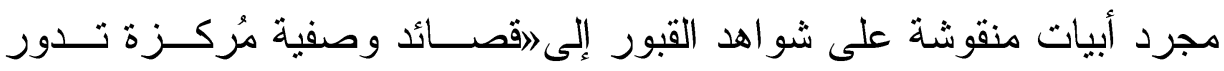

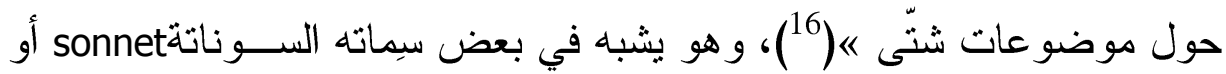
الهايكو الياباني(17). قد أسهم الأوربيوون في تطور هذا الفن منذ نهاية القرن الثامن عشر وبداية

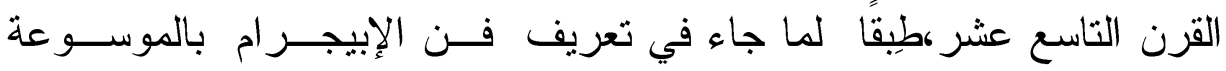
البريطانية و اأنه كتابة تصلح للنحت على أي أثر أو تمثال... وقد أصبح الاسم الإبه

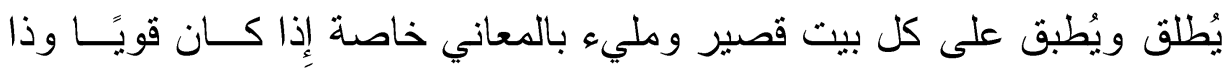

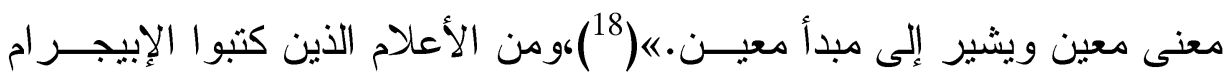

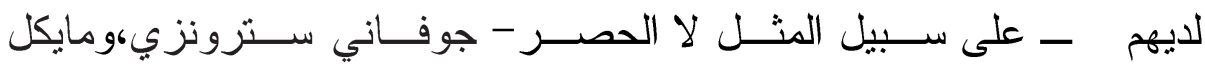

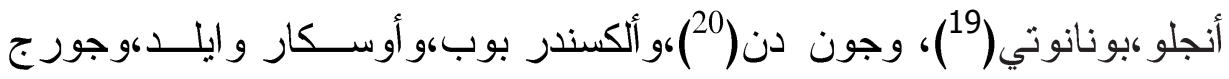

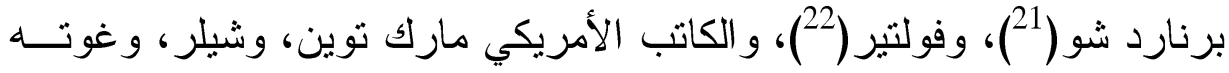
وبريخت الأدباء الألمان(

ولقد كتب الألماني(Otto Kno"rrich)عن فن الإبيجر ام أنه من أقدم الأجنــاس

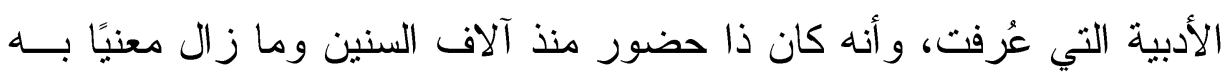
و أنه يخص الأشكال القصصية القصيرة التي عُرفت من قبل القرن الثران الثامن قبل

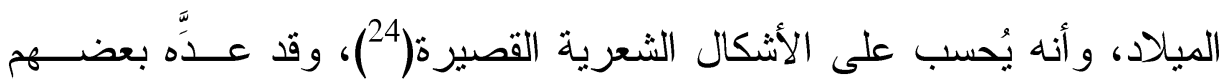


مقطوعة قصيرة ساخرة كانت تُكتب على شو اهد القبور ،و على هــــايا أعيـاد

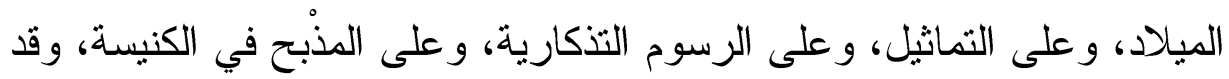

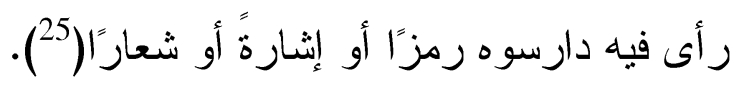

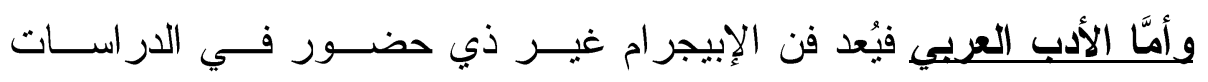

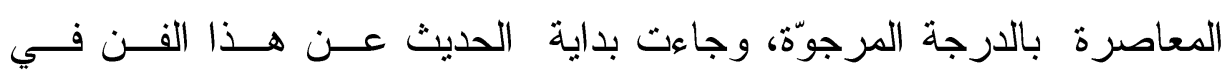

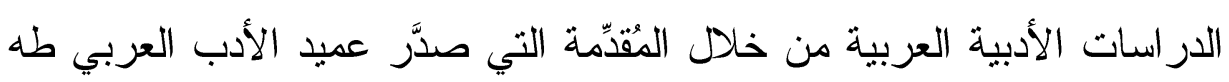

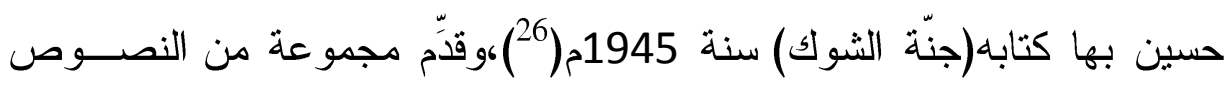

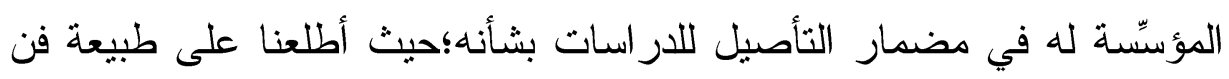

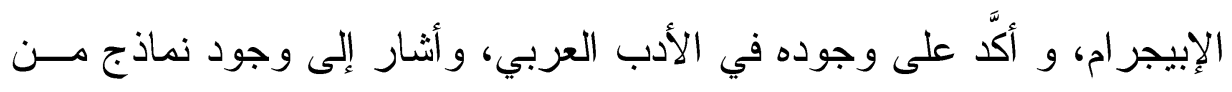

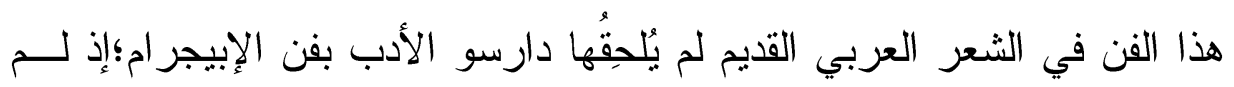

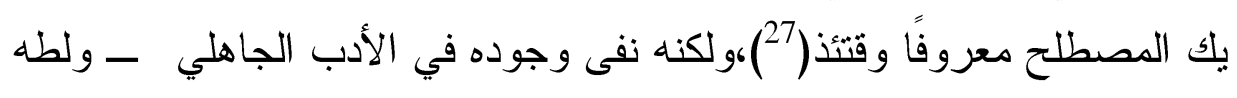

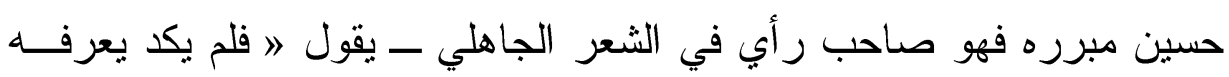

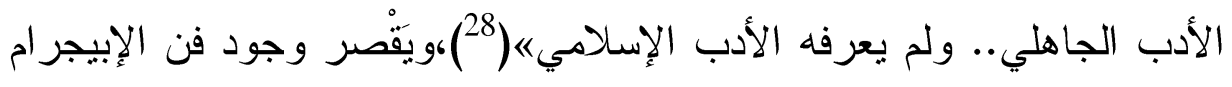

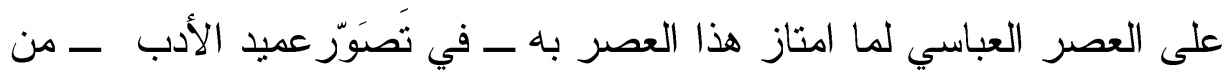

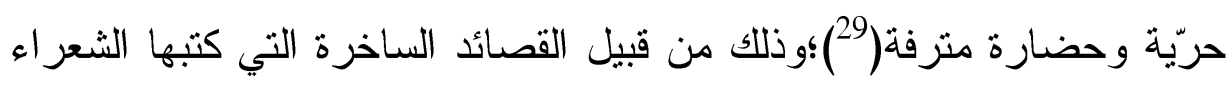
من أمثال؛ بشار بن برد،وحماد عجرد،ومطيع بن إياس، و أضر ابهم في البصرة

$$
\text { و الكوفة وبغداد (30). }
$$

ولم يقف عطاء طه حسين في هذا المضمار عند حدِّ التَّأصيل لهذا الفــن

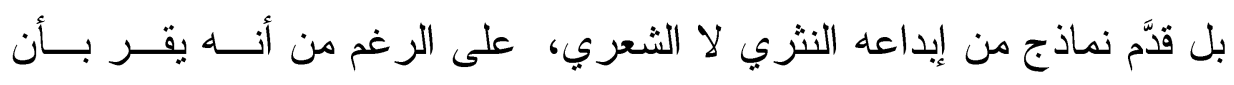

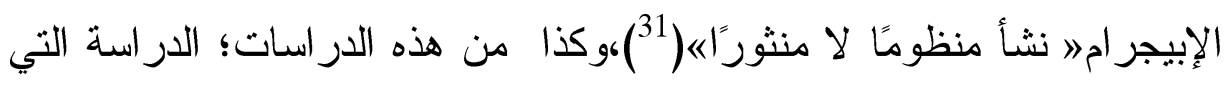

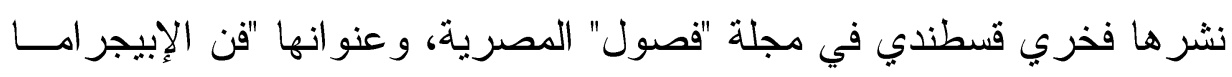

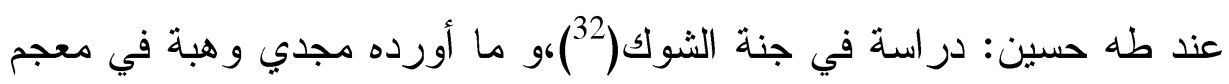
المصطلحات الأدبية(33)، ومن الثعر اء العرب في فئة العصر الحديث الذين كتبوا

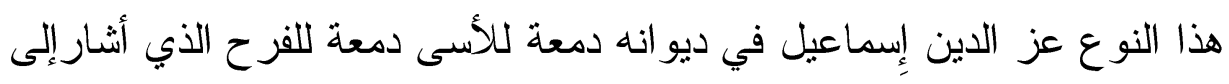




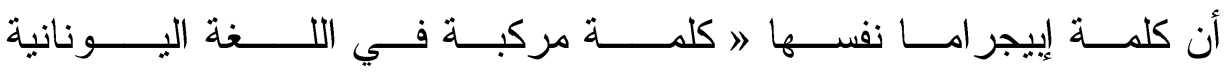

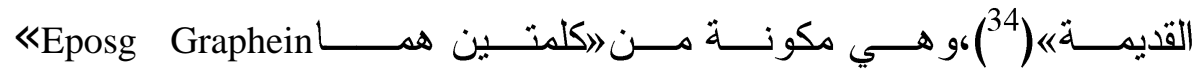

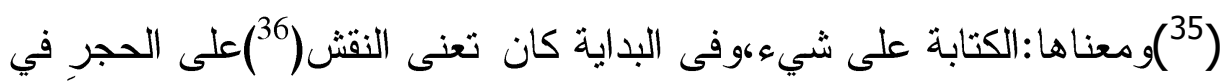

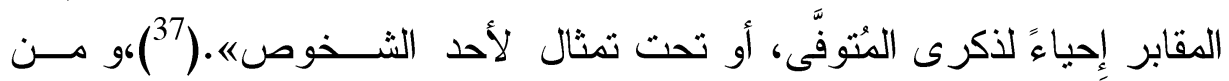

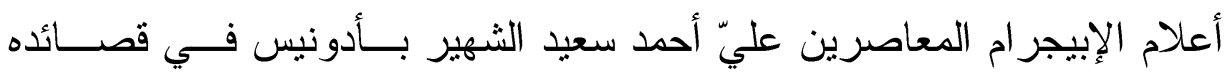

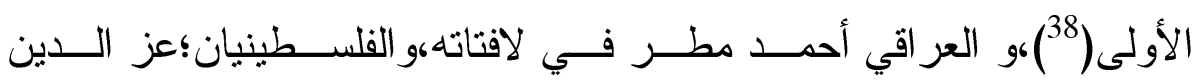

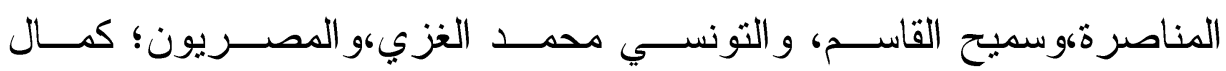
نشأت،و عز الدين إسماعيل، وحسن فتح الباب،و عبد المنعم عوَّاد يوسف ( و غير هم كثيرون الذين كتبوا هذا الفن وقد سبقهم العقاد في كتابه (آخر كلمات

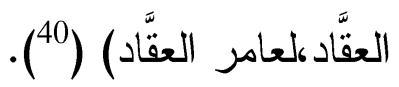

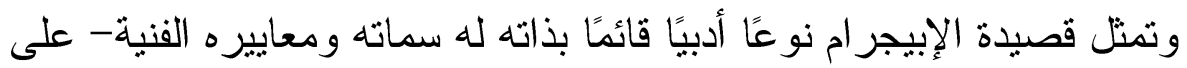

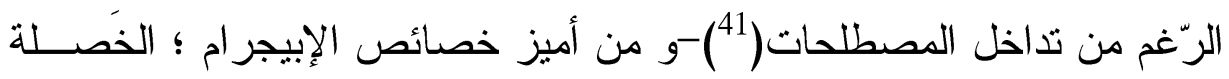

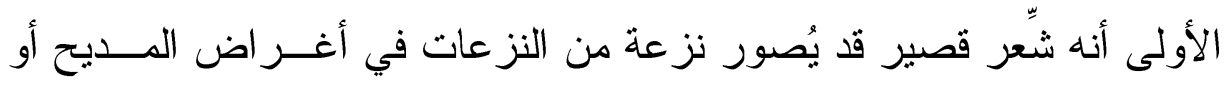

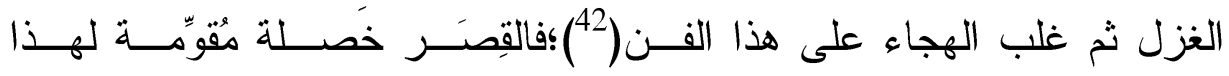
الفن(33)،الذي يتَّم »ابلتأنق الثديد في اختيار ألفاظه بحيث يرتفع عن الألفاظ المبتذلة دون أن تبلغ رصانة اللفظ الذي يقصد إليه الشعر اء الفحول في القصائد

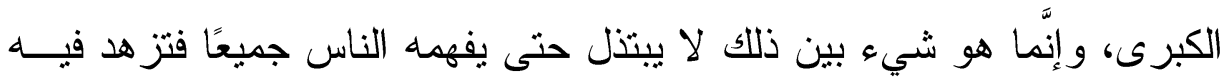

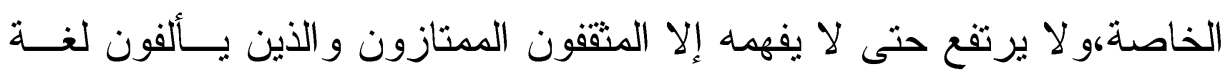

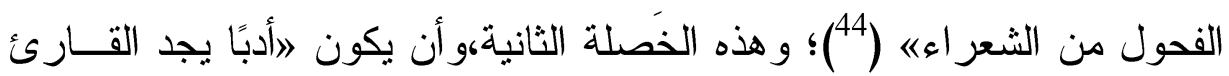
فيه ما يحب أن يجد في الأدب من لذَّة العقل، و الذّوق، و القلب، و الأذن، و اللسان

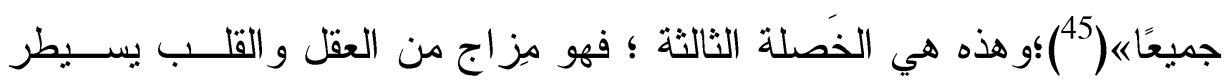

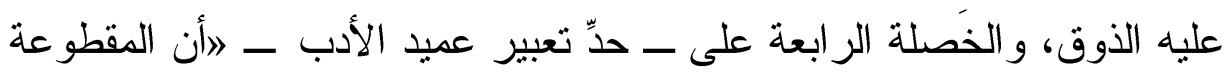

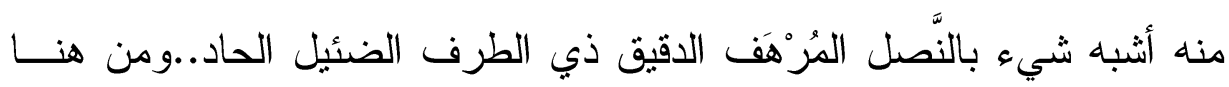
امتاز هذا الفن بالبيت الأخير أو البيتين الأخيرين من المقطوعة ؛ فهما يقومان

doi: $10.12816 / 0010463$ 
منها مقام الطرف الضئيل النحيل الرقيق الرشيق من نصل السهم؛ فإذا كانــــ المقطوعة بطيئة الحركة ثقيلة الوزن فليست من هذا الفن في شيءه(

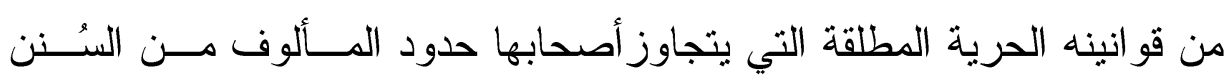

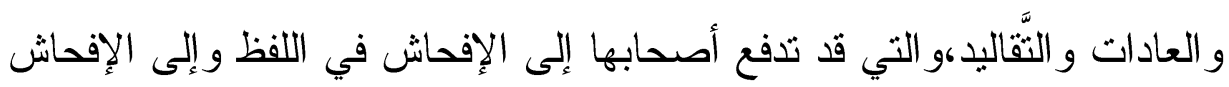

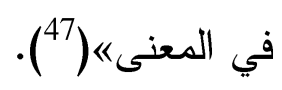

ويوضّح طه حسين أن مزيّة القِصر والإيجاز التي يمتاز فن الإبيجرام بهــا

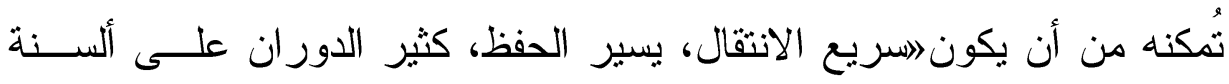

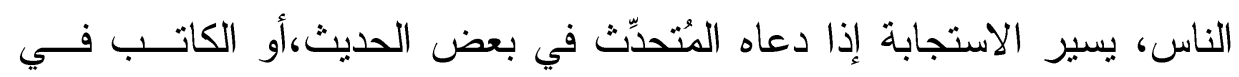

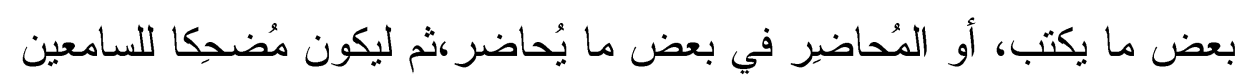

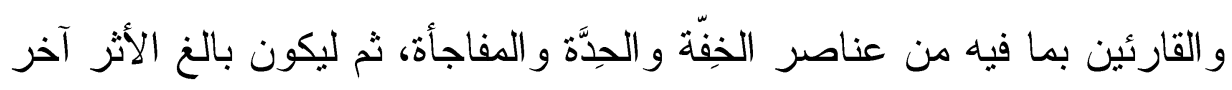

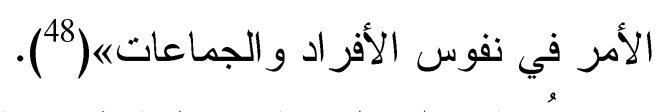

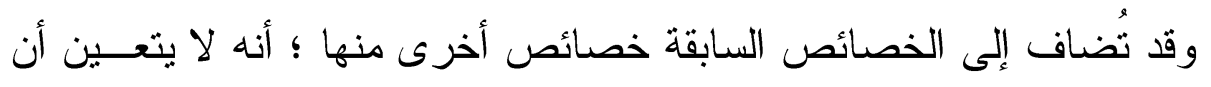

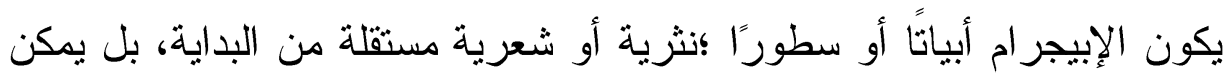

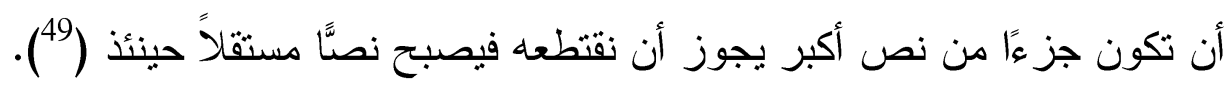
وجدير بالذكر أن فن الكاريكاتير من الفنون التي تتلاقى مع فن الإبيجر اما

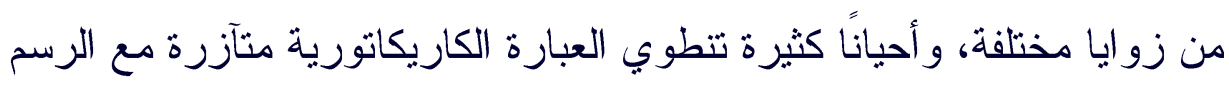

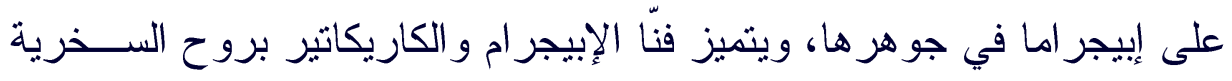

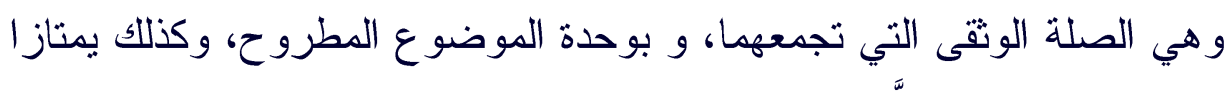

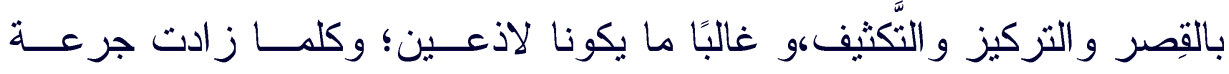

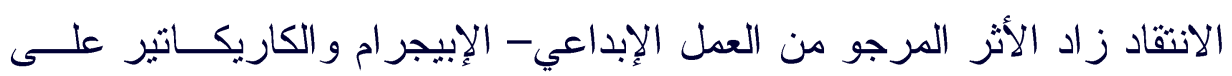

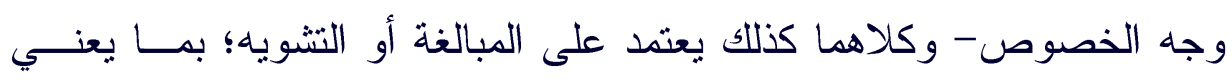
إظهار نسب الصورة و أبعادها على غير حقبقتها بقصد أن يلفت الانتباه ويستثير

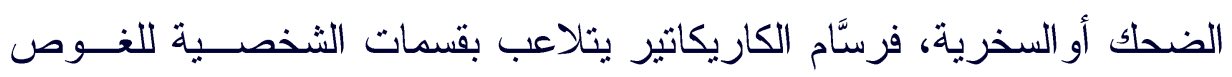

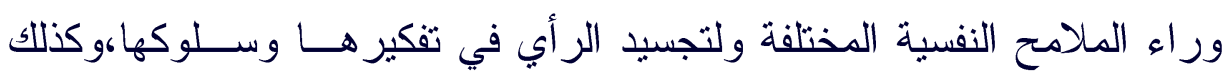


مُبدع الإبيجر ام يلجأ إلى المبالغة معتمدًا في عرض أفكاره على تشكيل اللغة في

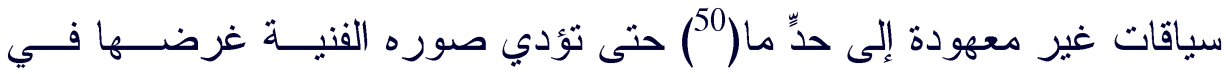
الإمتاع و الإقناع، و التأثير في المتلفي.

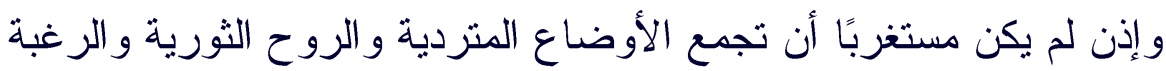

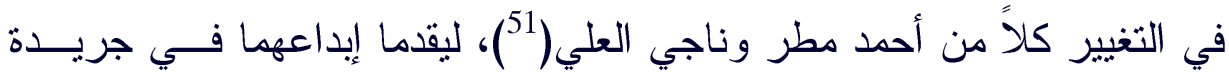

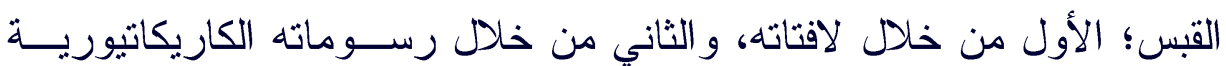

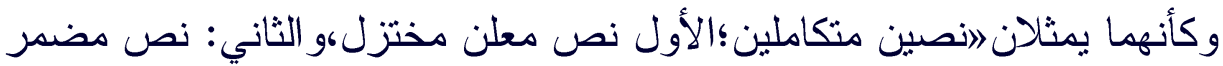

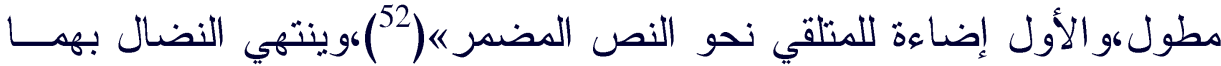

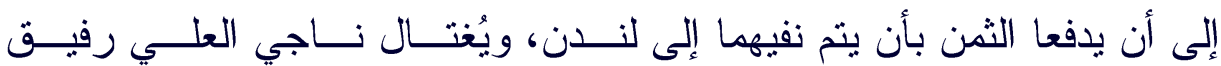

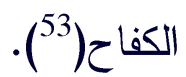
ولعل هذه الصورة النضالية لهما تتطبق مع ما أشار طه حسين إليــهـ عـنـ

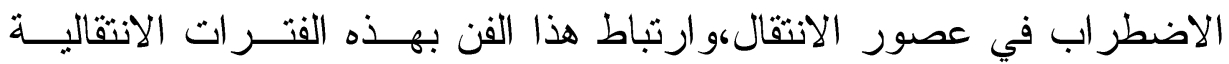

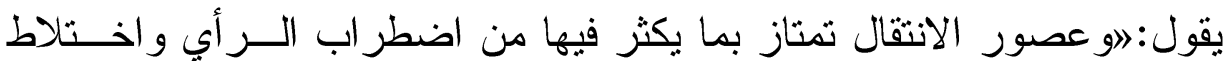
الأمر و انحر اف السيرة الفردية و الاجتماعية عن المألوف من مناهج الحيــاةهـ (54)، وفي ذللك النمط تتخذ الخصومة طابع الهجاء( (55). وثمة خلط كبير بين مصطلحي قصبدة الومضـــة القصــيرة جدًا والقصــيدة

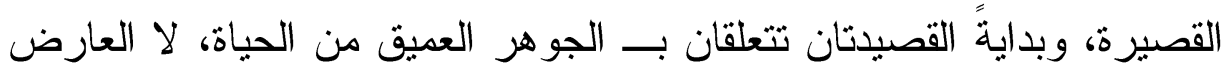
السهل؛ و القصبدة الومضة/القصيدة قصيرة جدًا لا تتجاوز في العادة عدة كلمات

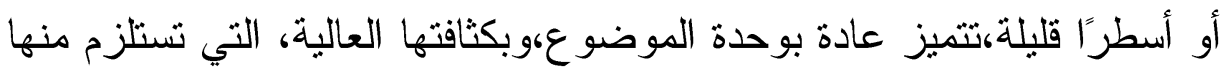
الاقتصاد الثديد في استعمال حروف العطف، و المفردات الكمالية التي لا تخدم

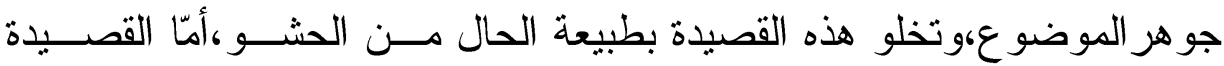

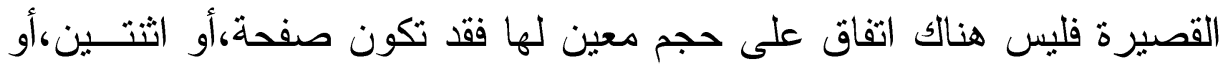

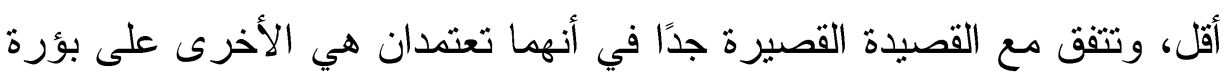

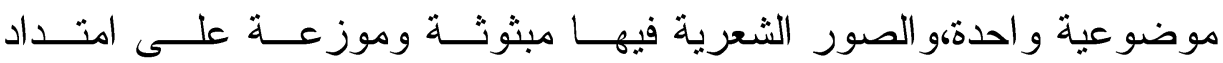


النص،ويمكن القول إنه كلما اتجهت القصيدة أكثــر فــأكثر باتجــــاه الكلمــات

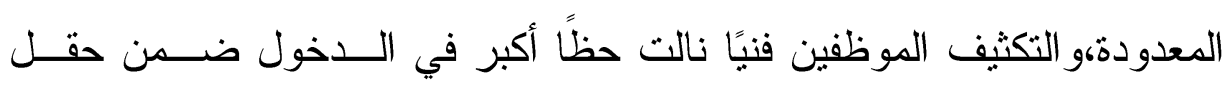

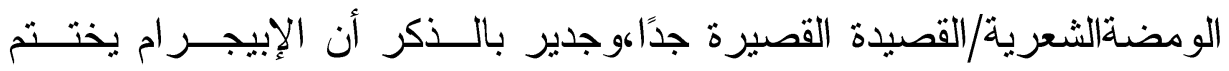

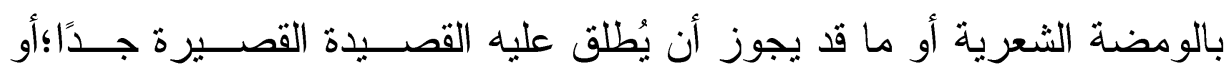

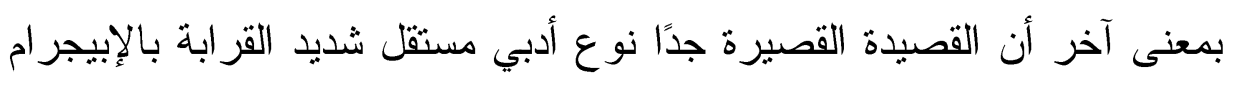

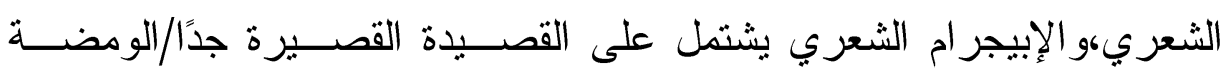

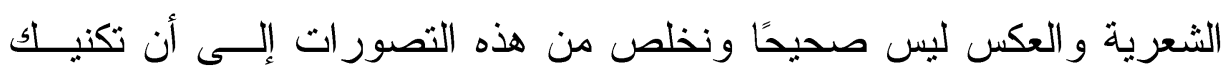

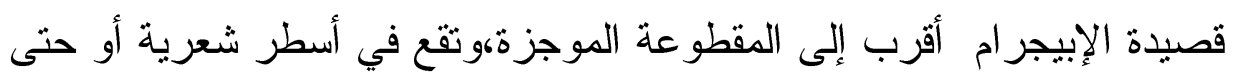

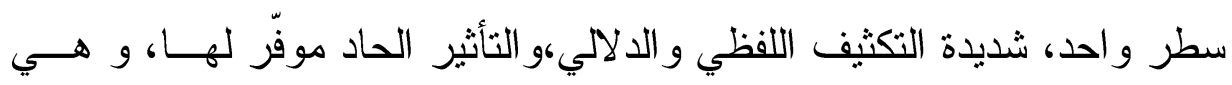
تحمل المفارقة حيال قضية ماكو يصوغها المبدع كما رشقة نصل نافذة تجري على لسان المتلقي مجرى الحِكمة التي يعيها اللب و القلب، وتبقى في الــذاكرة وتدور على الألسُن. و تُعد قصيدة الإبيجر ام واحدة من أنماط الشعر العربي المعاصــر ؛ فهـي

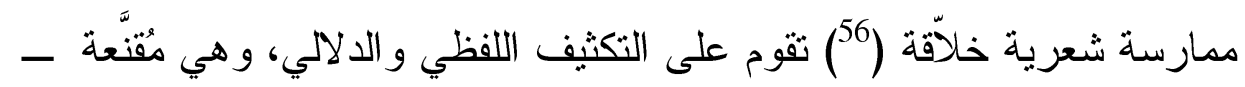

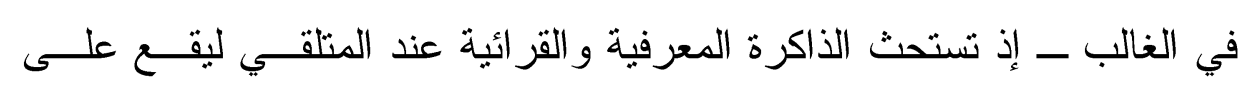

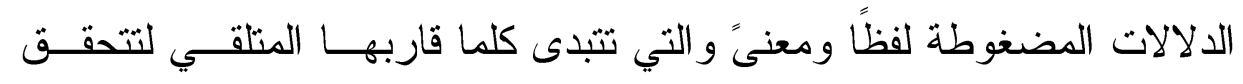

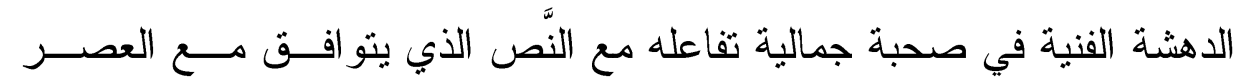

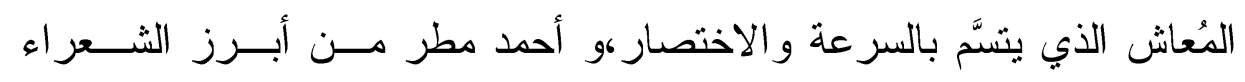

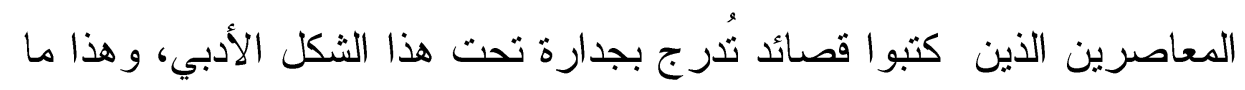
ستحاول هذه الدر اسة بحثة.

\section{ثنانبًا: بنبة قصبدة الإبيحر ام في النلافتات:}

الو اقع إن تحليل النصوص بوصفها نسيجًا لغويًا ينمو ويتطور هو في جوهره

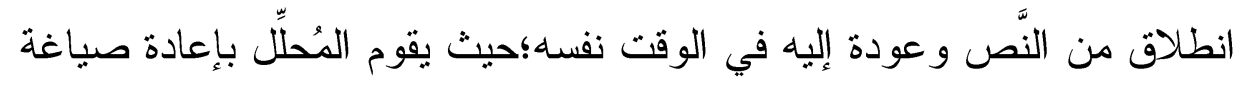

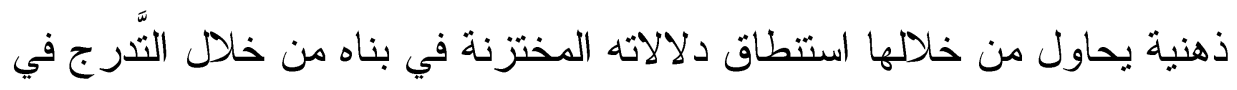


عملية التحليل عبر البنَى/المعمارية(77)التي يتشكل النص منها،بدءًا من اللفظة

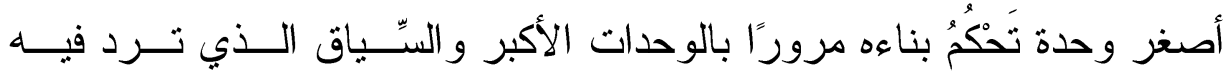

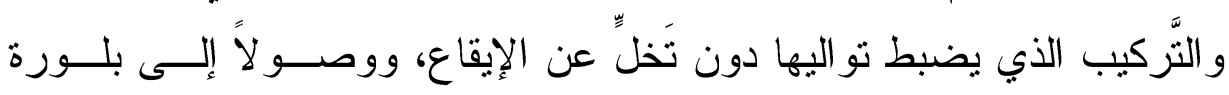

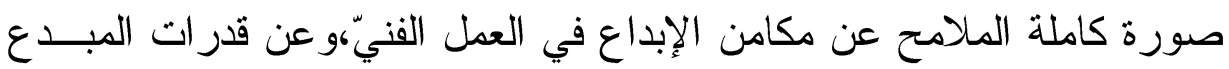
في توظيف لغته بما يترجم خو اطره ويكثف عن صدق تجربتــه الثــعورية

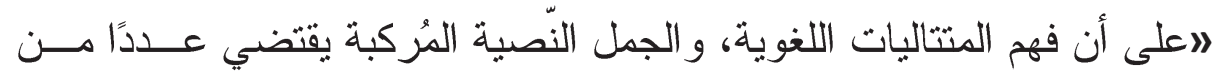
الملامح البارزة، ويأتي في مقدمتها طبقًا لآراء علماء النص المحدث النهاء أن عمليات التكوين تتجه بصفة خاصة إلى الجانب الدلالي؛أي أن المتحدث يريد أن يسجل في ذاكرته قبل كل شيء المعلومات المتصلة بالمضدون المأخوذ مــن الجمــلـل

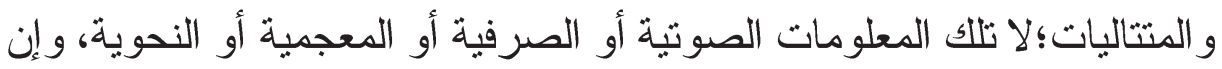
كانت هذه الأخيرة بطبيعة الحال أدوات يتم عن طريقها تكوين البيانات الدلالية

$$
\text { و التعبيز عنهاه.(1) }
$$

إن المزاوجة بين الدرسين اللساني والأدبي ضرورة تفرضها الصلة بينهما ومن أكثر المعايير أهمية في تحليل النصوص الأدبية هو هدى تحقـق رســالة

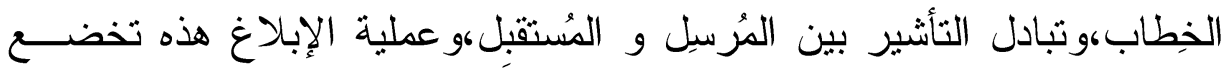

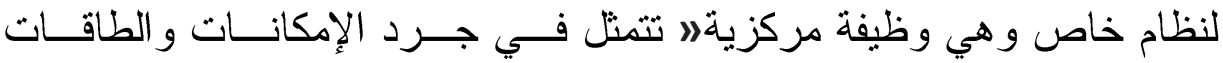

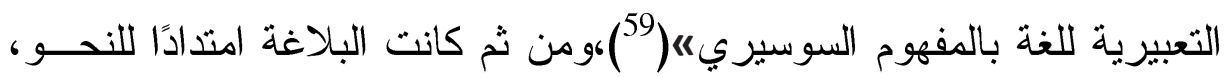

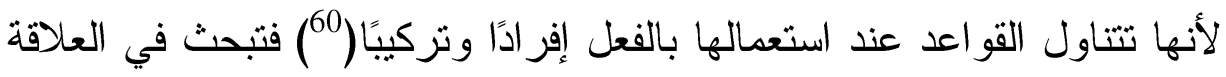

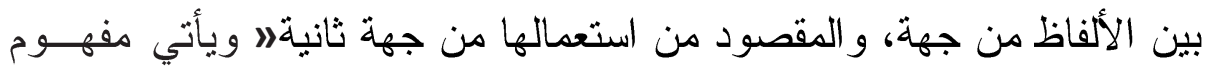
التداولية ليغطي بطريقة منهجية منظمة المساحة التي كان يشار إليها في البلاغة

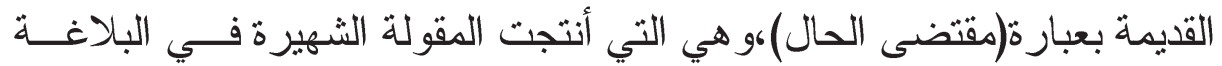
العربية(لكل مقام دقال)( (1).

قامت مبادئ الشعرية عند ا جاكوبسون هافي أحد أبعادها علــى تقريــبـ نظرية الوظيفة الشعرية من استر اتيجيات الخطاب الخاصة بالأدب و إذا كــان 
"جاكوبسون "لغويًا وصاحب نظرية في الشعرية في الآن ذاته، فإن ذلك لم يكن

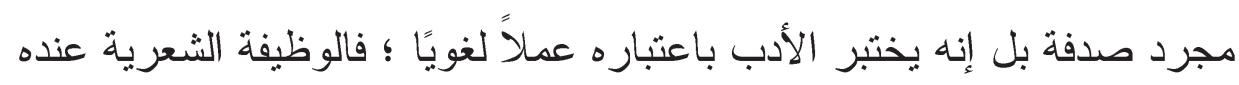

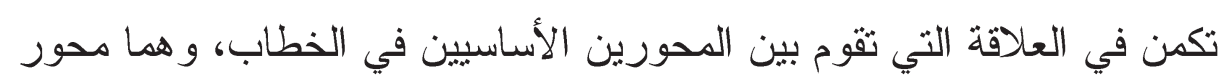

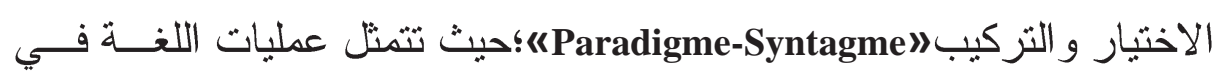

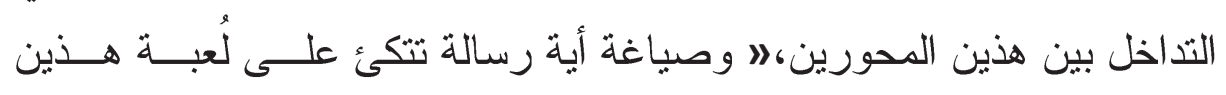

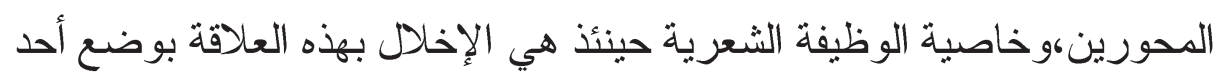

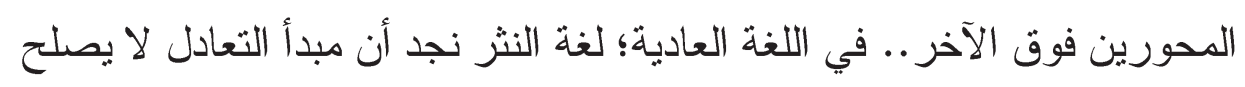

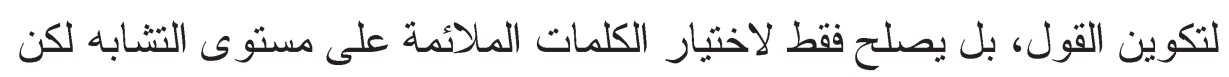

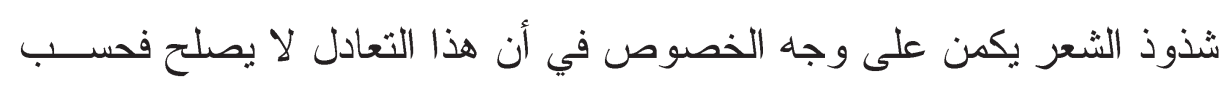

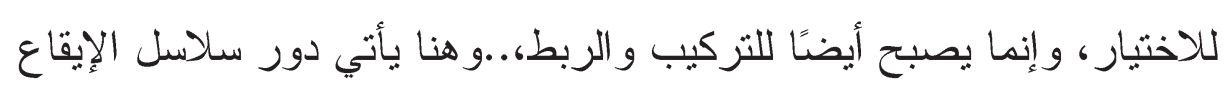

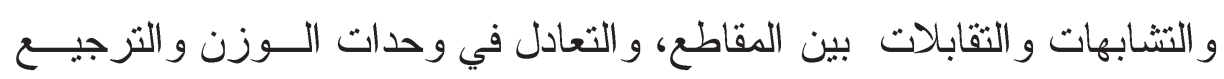
الدوري للقو افي في الثعر المقفّى"(26).

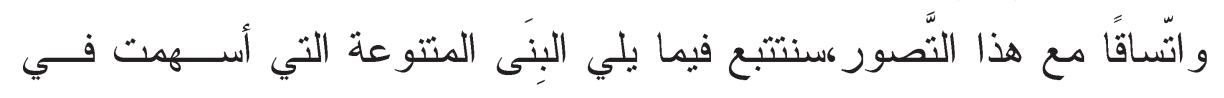

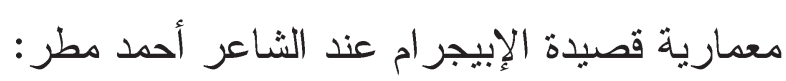
[أ] - البنية الإفر ادبية و المعمم الثبعري في الإبيجر ام عند أحمد مطر:

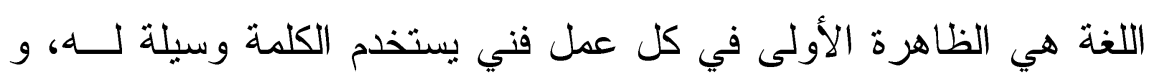

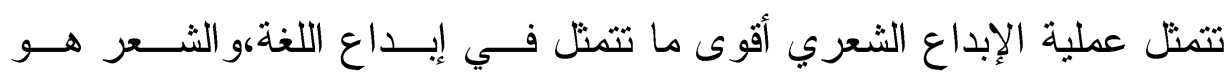
استكشاف دائم لعالم الكلمة و الوجوداومن ثم كان الثـــعر هو الوســـيلة الوحيدة

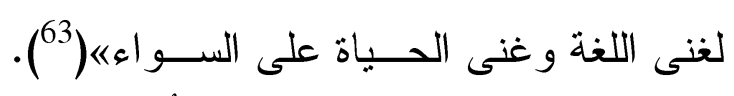

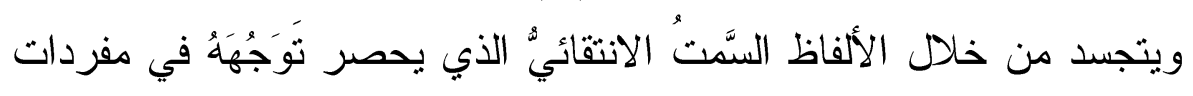

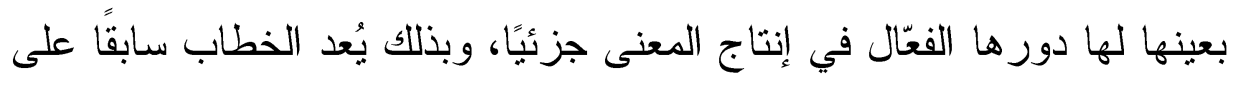

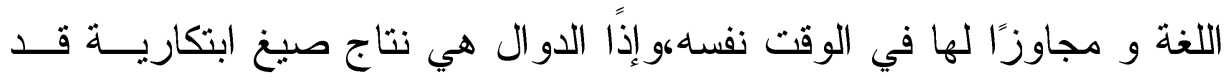
يَحدث أن تتحاز في مرحلة بعدية إلى اللغة( 


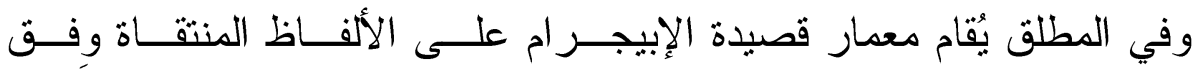

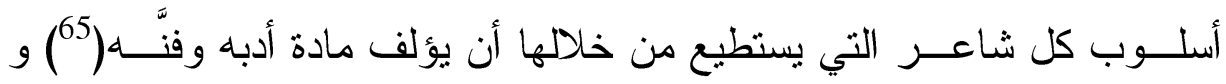

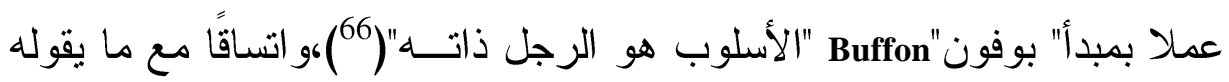

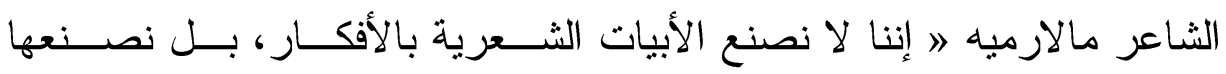

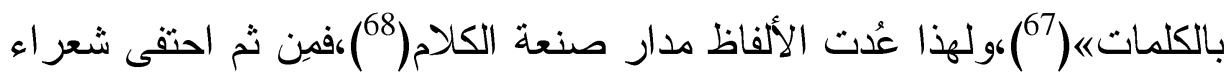

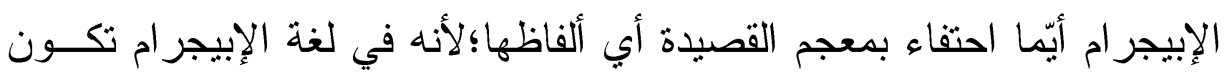

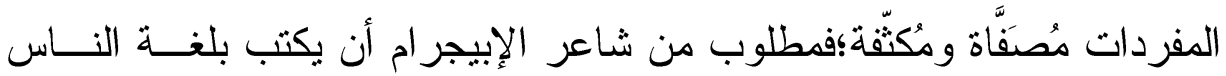

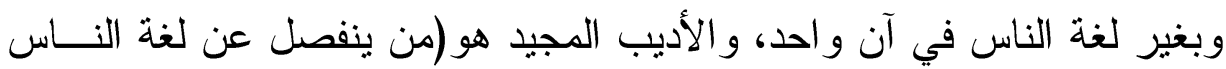

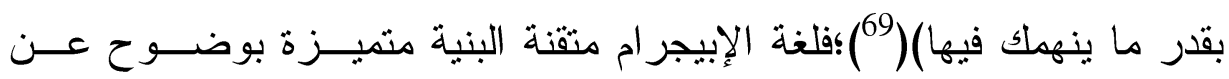

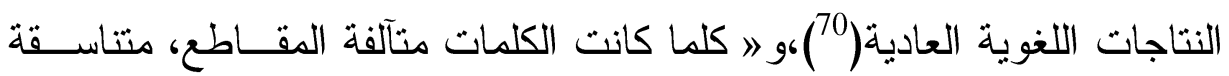

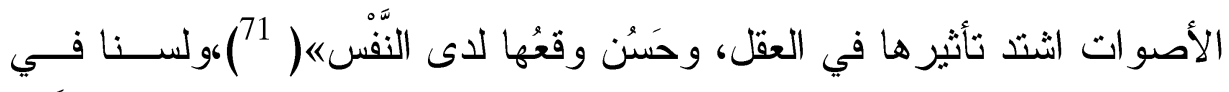
حاجة إلى الإشارة إلى وجوب اقتران تخيّر اللفظ بمر اعاة المعنى على الــنَّهج

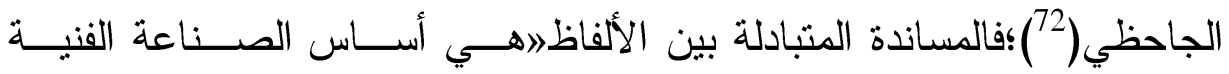

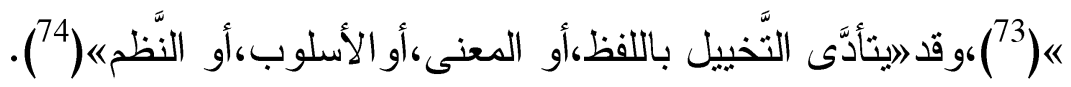
ومن هذا النمط لدى الثاعر أحمد مطر قوله: أنا أقول كلمة

\section{وهو يقول كلمة} و وإنه من بعد أن يقولها. يسير وإنني من بعد أن أقولها..

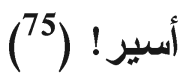

وبعد فسنتبع الألفاظ الثائعة في لافتات أحمد مطر و التي سيطرت وكان لها

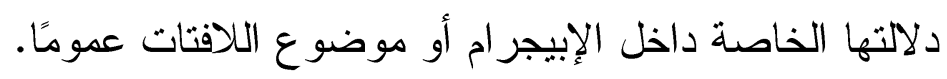




\section{1 - مفردات السباسة، و الرَّفضض، و الثجن:}

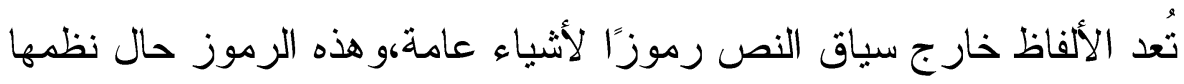

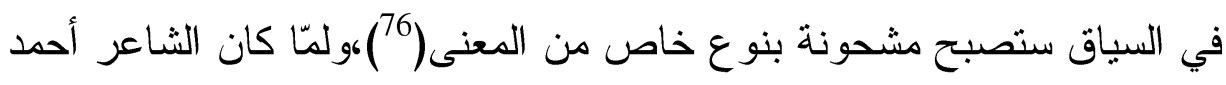

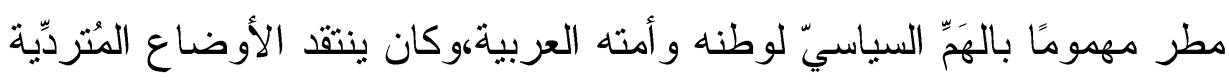

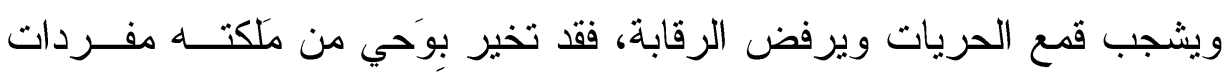

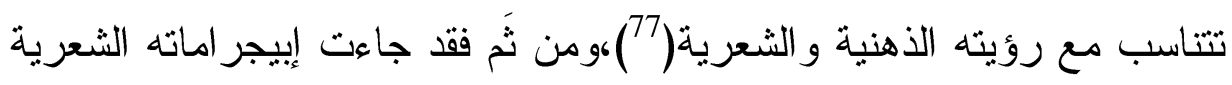

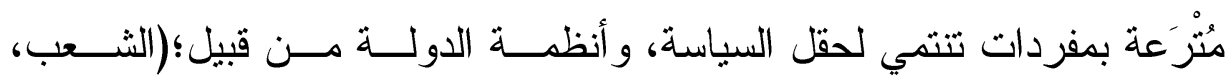
a

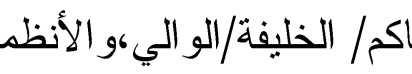

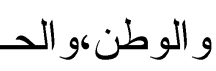

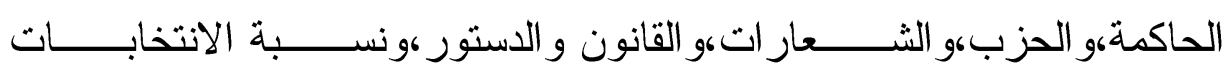

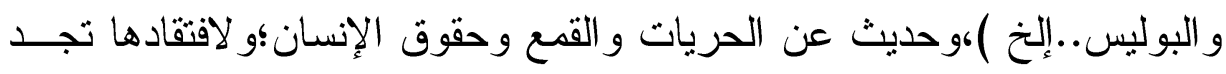

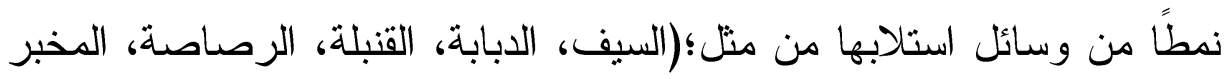

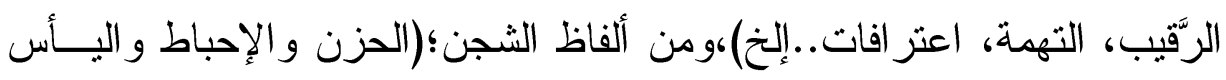

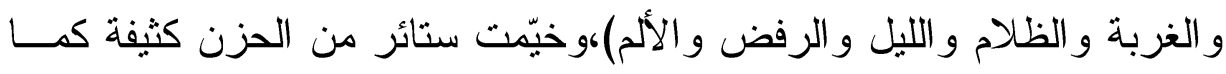

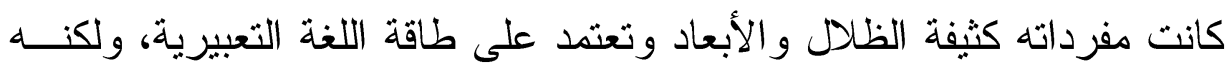

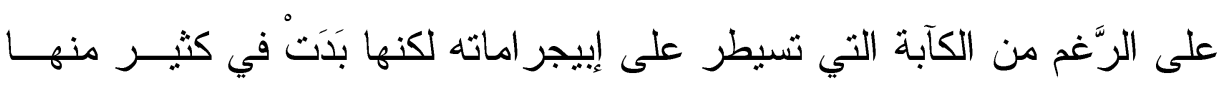

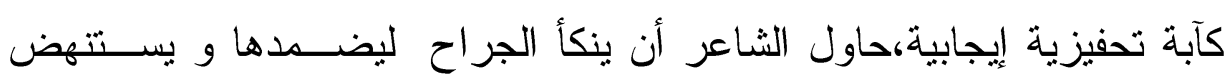

$$
\text { الشعوب العربية. }
$$

وفي الإبيجرام الآتي يكشف أحمد مطر عن أسباب الحزن الذي يلُف حياتــهـ

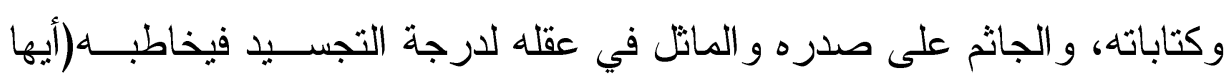

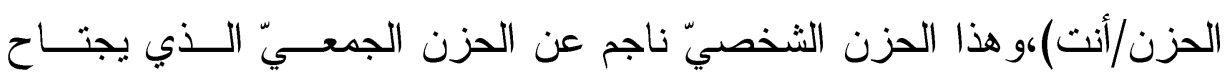

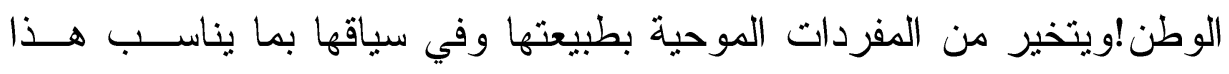

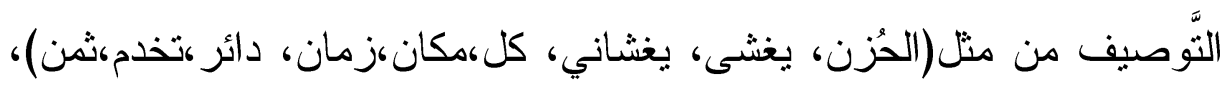
يقول: أيها الحزن الذي يغشى بلادي 


$$
\begin{aligned}
& \text { أنت في كل مكان } \\
& \text { أنت في كل زمن. } \\
& \text { دائر تخدم كل الناس } \\
& \text { من غير ثن..(18) }
\end{aligned}
$$

وفي إبيجرام آخر يُحذر الثشاعر من غضبة الثُعوب اليائسة التي لا تشــر

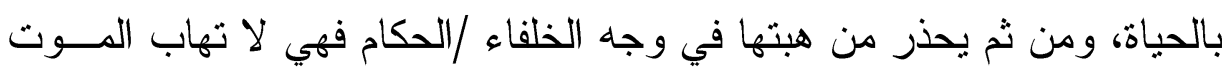

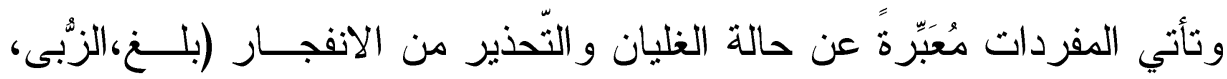
نحن، الموت، سو اء، فاحذروا، لا يخاف، المنايا، الشعب، لغمًا، شظايا)، يقول:

$$
\begin{aligned}
& \text { بلغ السيل الزُبْى } \\
& \text { ها نحن و الموت سو اءٔ. } \\
& \text { فاحذرو ا يا خلفاء }
\end{aligned}
$$

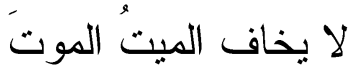

$$
\begin{aligned}
& \text { فإذا ما أصبح العيش } \\
& \text { قرينا للمنايا } \\
& \text { فسيغدو الشعب لَغًْا } \\
& \text {.. وستغدون شظايا(19). }
\end{aligned}
$$

و يسخر الثشاعر من الثعوب العربية المستسلمة لما يَنْبه ساستهم إليهم من

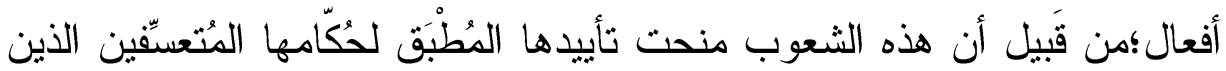

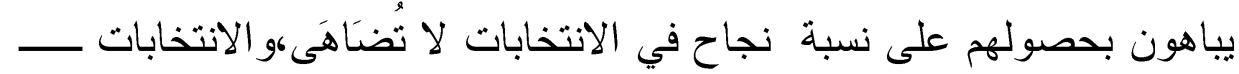

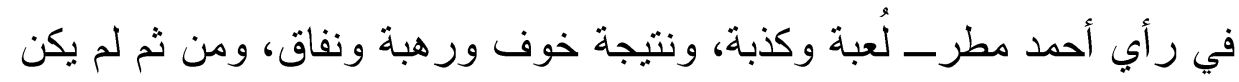

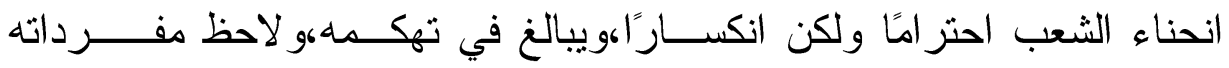

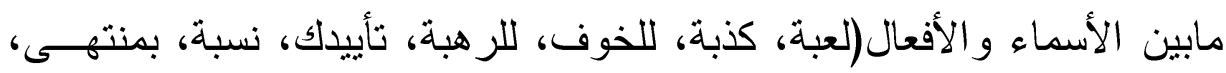

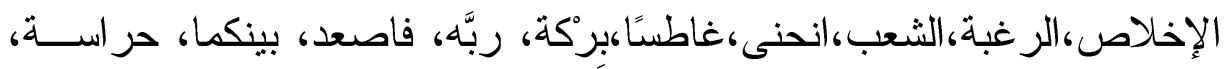

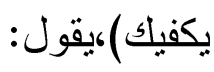




$$
\begin{aligned}
& \text { لا.. لم تكن لعبة } \\
& \text { ولم تكن كذبة } \\
& \text { ولم تكن خلاصة للخوف و الرهبة } \\
& \text { نسبة تأيبدك جاءت كلها } \\
& \text { بمنتهى الإخلاص و الرّغبة. } \\
& \text { الشعب كله انحنى الثن } \\
& \text { يا غاطسًا في بركة الحُبِّ إلى الرُّكبة } \\
& \text { فاصعد إلى الشعب إذن } \\
& \text { مرتديًا حبَّه. } \\
& \text { ولا تضـع بينكما حر اسةٍ } \\
& \text { يكفيك أن تحرسك (النسِبة)( }
\end{aligned}
$$

وينفث الشاعر معاناته بسبب نفيه(18)،و الرقابة الصـارمة عليـهـه وكتاباتــهـ

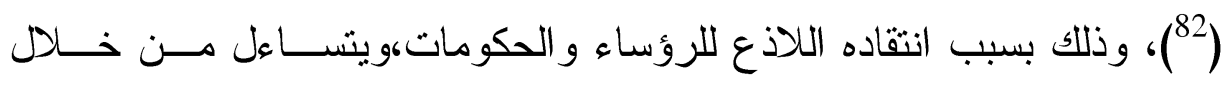

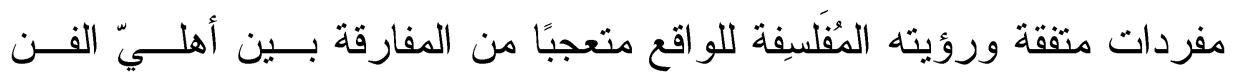
و السياسة حيث يوضـع الرجالات في غير أماكنهم المُستحَّةَ! مثل (بدمي،شقائي، الفن، السياسة، ساسة،عبد،قداسة )،فيقول:

$$
\text { فأنا الفن...و أهل الفن لوحات شقائي }
$$

فلماذا أنا عبد و السياسيون أصحاب قداسة ؟!((83).

عن الأسى ومفرداته التي تضجهُ لافتاته بها نتيجة محنة الأوطان و النّفي الذي

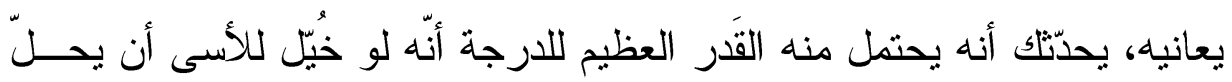

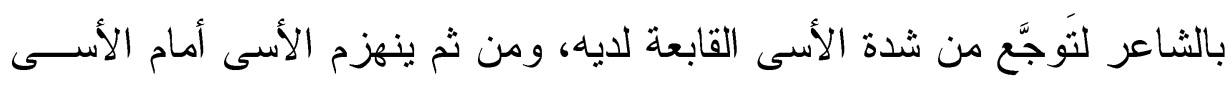
الر اسخ بنفس الشاعر، و عليه يعود القهقرى!،و لاحظ دلالة الفعل(يغشى) وما فيه 
من تغطية وتطويق و انتشار فإطباق، ومن ثم تشيع مفردات الحزن التي تشــع

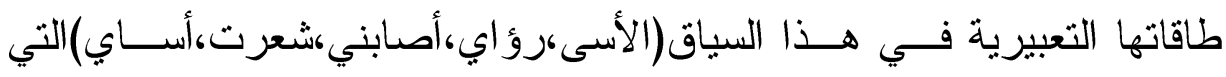
جاءت جميعها مناسيبة وبليغة في نطاق رؤية الثاعر ، يقول:

$$
\text { ليغشى الأسى رؤاي }
$$

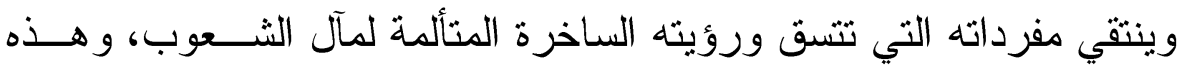

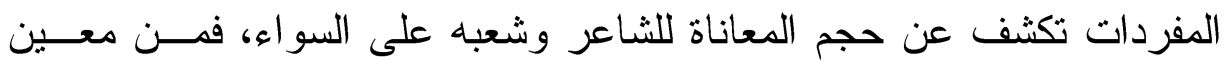

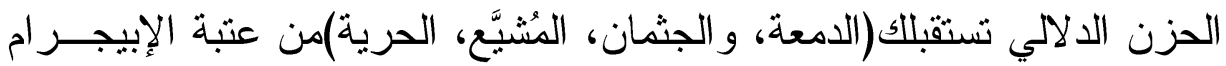

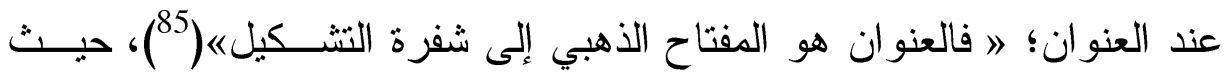

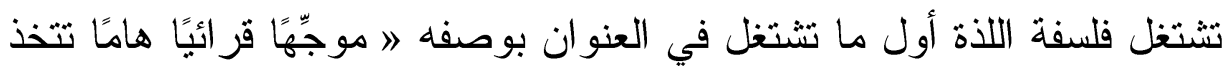

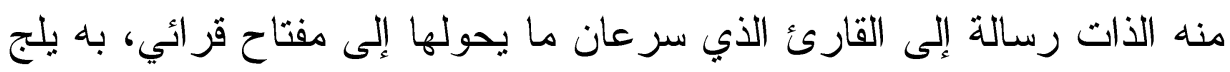

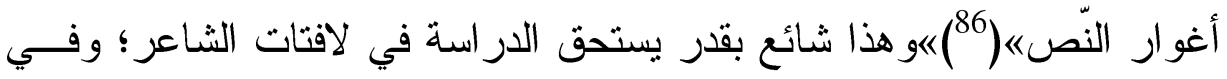

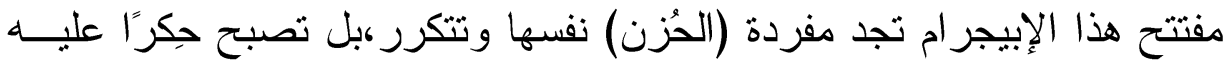

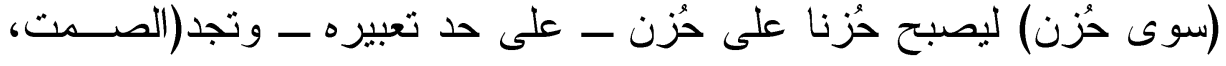

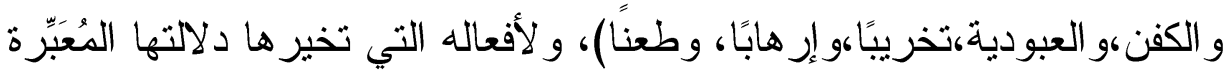

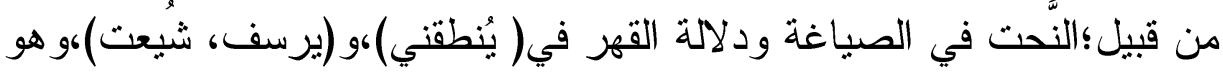

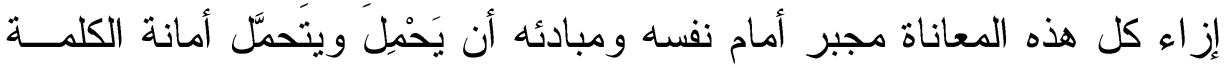

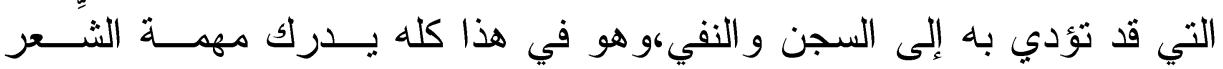

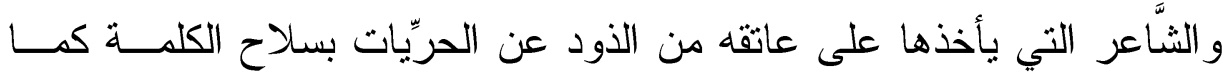

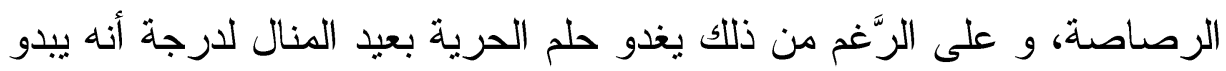

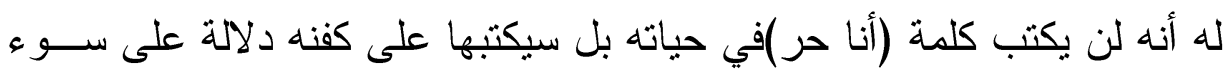


الأوضاع السياسية وترديها - في وجهة نظره ــ يقول في إبيجــر ام يتضــمن

$$
\begin{aligned}
& \text { سلسلة إبيجر امات(187): } \\
& \text { ] (أنا لا أكتبُ الأشعار ] } \\
& \text { فالأشعار تَكْتُنيني) } \\
& \text { (أريد الصمت كي أحيا (لأنيان) } \\
& \text { ولكن الذي ألقاه يُنطقني) } \\
& \text { (و لا ألقى سوى حزن }
\end{aligned}
$$

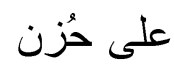

$$
\begin{aligned}
& \text { على حُزن) } \\
& \text { (أأكتب" أنني حي" على كَفتِي ؟ } \\
& \text { أأكتب" إنني حُر ") } \\
& \text { وحتى الحرف يَرسف بالعبودية ؟ } \\
& \text { (لقد شيعت فاتتة } \\
& \text { تُمى في بلاد العرب تخريبًا } \\
& \text { و إر هابًا } \\
& \text { وطعنًا في القوانين الإلهيهُ... } \\
& \text { لكن اسمها في الأصل }
\end{aligned}
$$

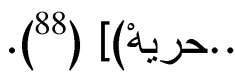

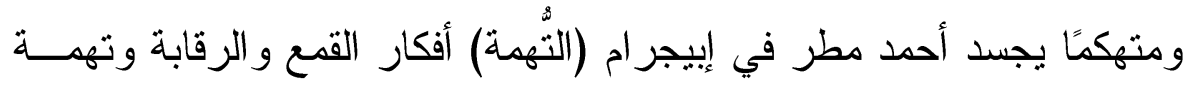

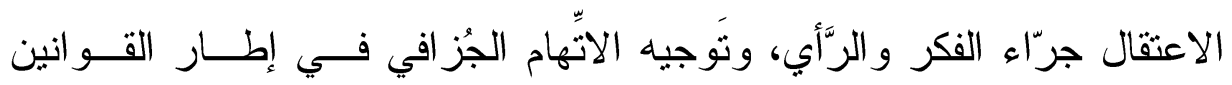

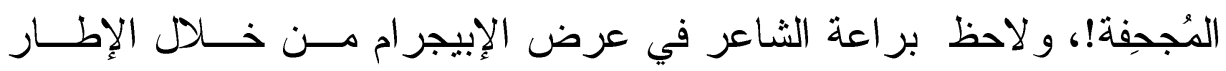

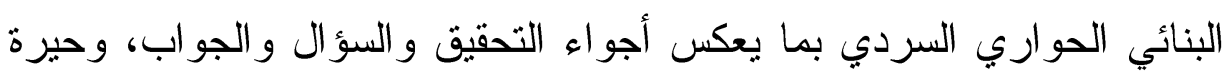

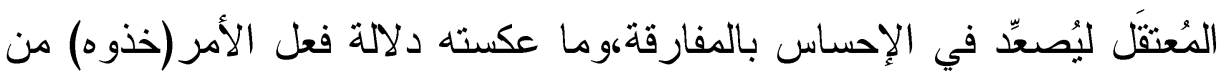


الاقتضاب والامتهان،ودلالة الفعل المبني للمجهول(قيل لي)على فكـرة عــدم الاكتراث لأمره إمعانًا في احتقاره، يقول:

كنت أسير مفردًا

أحمل أفكاري معي مني

$$
\text { ومنطقي ومسمعي }
$$

فازدحمت من حولي الوجوه ومني

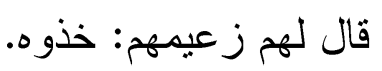

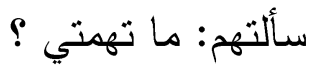
فقيل لي:

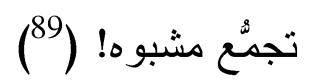

و عن رسالة الثاعر في كل زمن التي يتحمل عبئها بأمانة وشرف مما يجعله

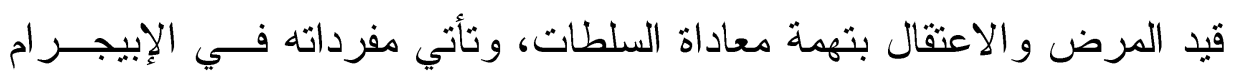

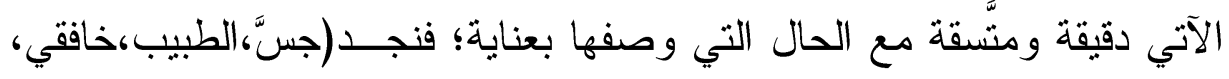

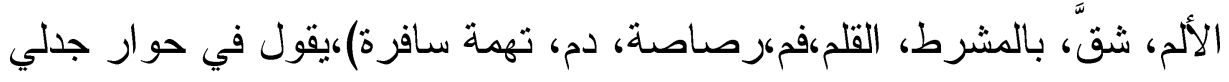

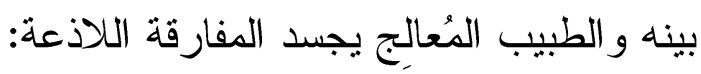
جسَّ الطبيب خافقي وقال لي: - منا:

هل هنا الألم ؟ كل:

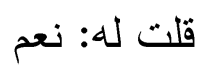

فشق بالمشرط جيب معطفي و أخرج القلمْ هزَّ الطبيب ر أسهـ..ومال و ابتسم قال لي: ليس سوى قلم 


$$
\begin{aligned}
& \text { فقلت: لا يا سيدي } \\
& \text { هذا بدُ.. وفمْ } \\
& \text { رصاصةٌ.. ودمْ } \\
& \text { وتهمةٌ سافرة" رصنّة } \\
& \text {. . تمشي بلا قدم (90) }
\end{aligned}
$$

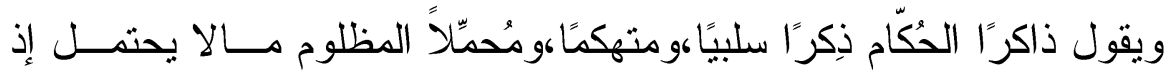
ينزع عنه الرجاء و الدعاء على من ظلَّهه بل بطلب منه شكر الله على أن مكّن

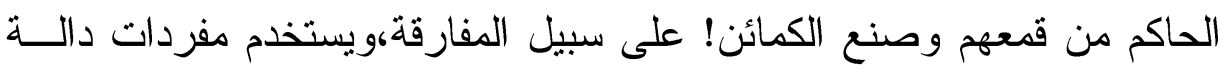

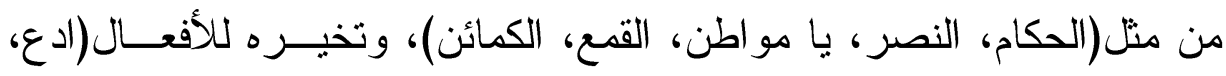

$$
\text { أشكر)، يقول: }
$$

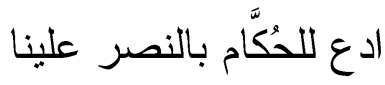

$$
\text { يا مو اطن }
$$

و اشكر اله الذي ألهمهم مو هبة القمع

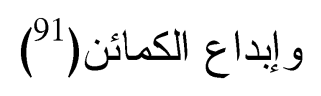

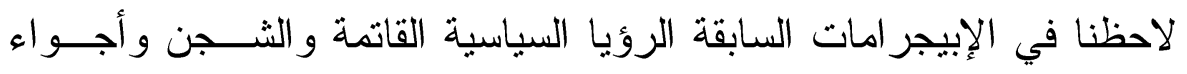

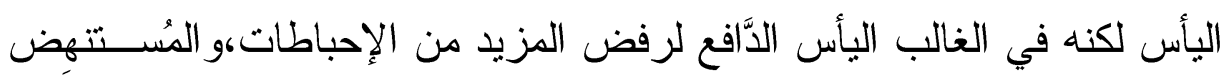

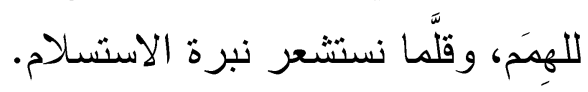

\section{2 ـ مفردات الزمان:}

عامةً فإنه يمكن القول:لا توجد مثالية للزمن،وسيمة الزمن ليست في استمر اره

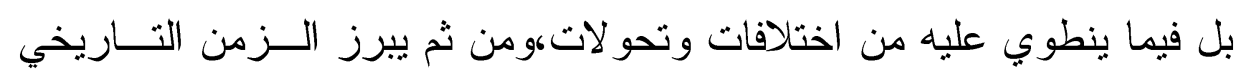

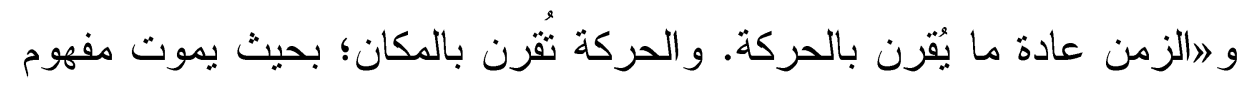

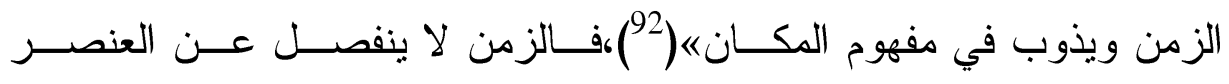

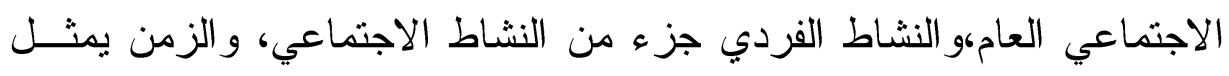

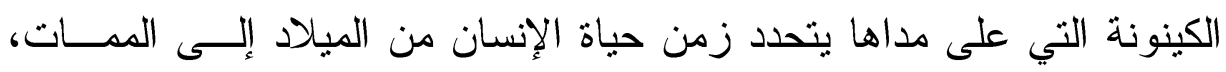




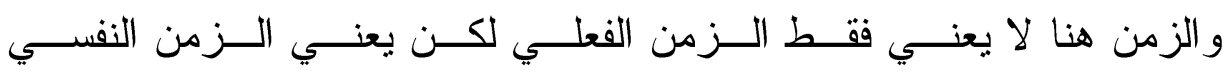

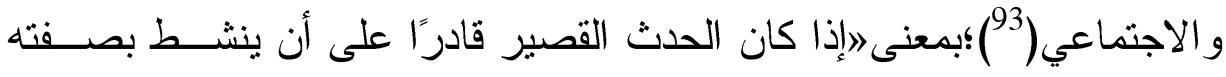

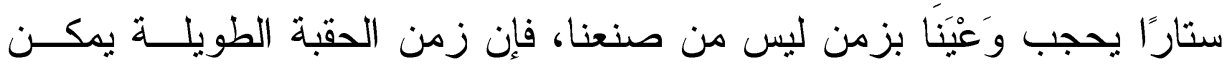

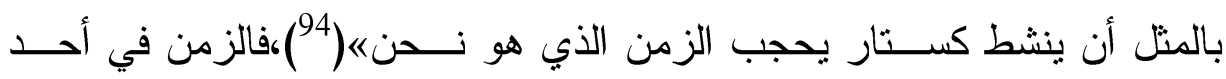

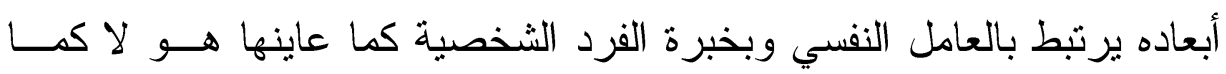
يسجلها المؤرخ. وتبدّى الاحتفاء بالزمن في شعر الإبيجر ام ؛ ربما استتادًا في العموم إلى أن

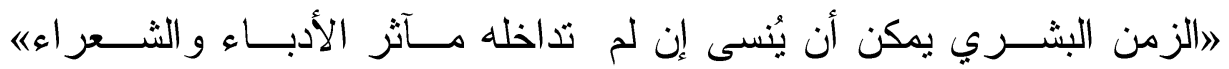

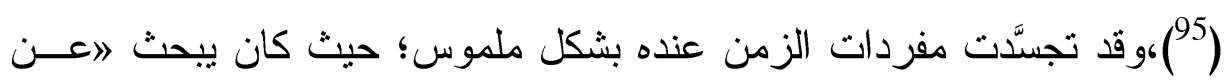

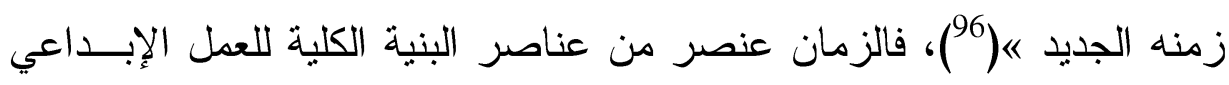

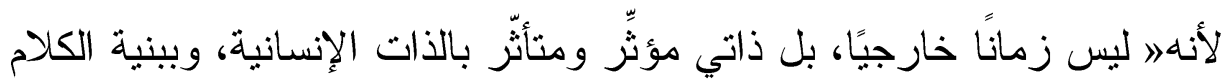

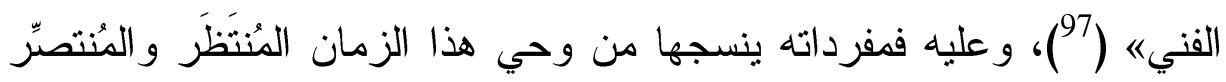
و الذي له ثمن (الصبح، أسفر، طهر، ضحايانا، سنريكم)، يقول:

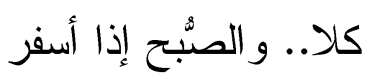
سنريكم سود لياليكم

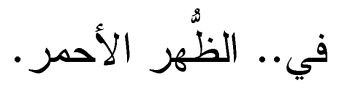

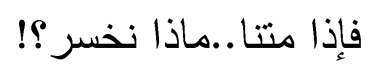
كل فتى منا قنبلةٌ فانتظرو ا..حتى نتفجَّرْ! (98)

يتو عد الثشاعر اليهود بسحقة تُصبِّهم فتقتص لفلسطين وما تبعها من هــز ائم

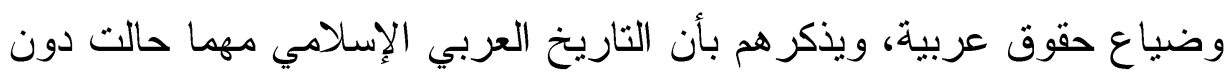

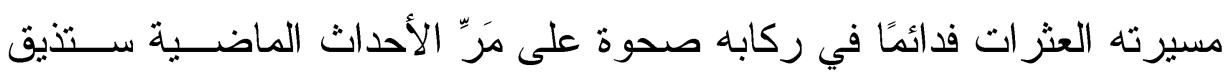

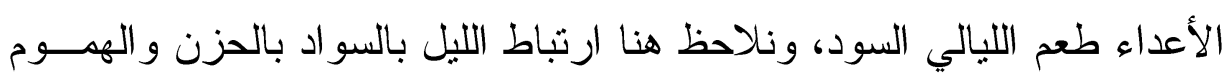

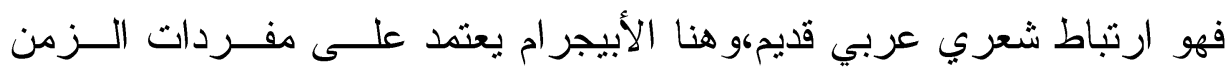


وخصائصه و ألو انه (الصبح،أسفر،ليالي،الظهر،الأحمر)،و يحدد من خلال هذه

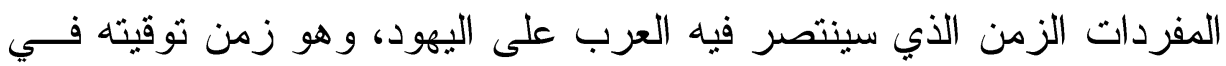

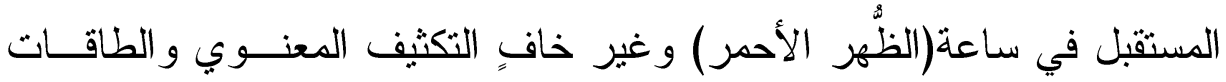

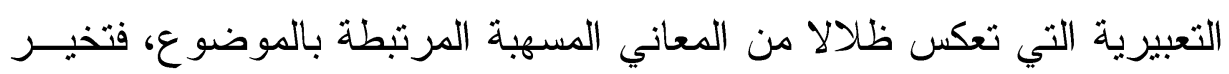

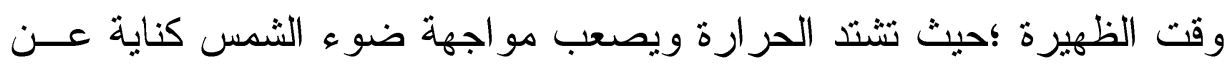
عجز مواجهة اليهود للعرب،ووصف الظهر بأنه أحمر(99) وما يحمل هذا اللون

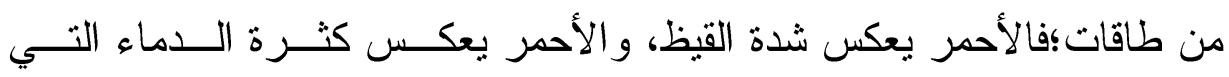

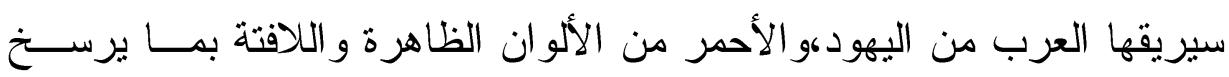

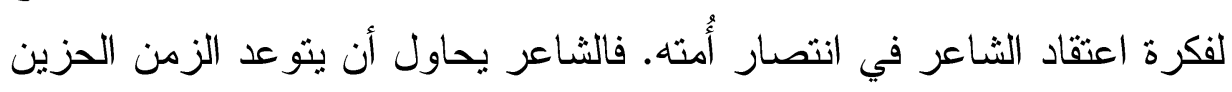

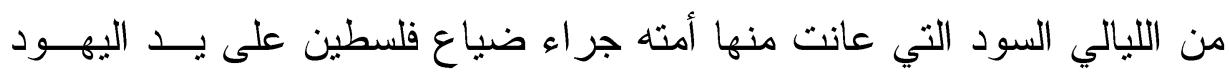
ويو اجه هذا الزمن الحزين بزمن وضّاح مستقبلي يأمل معه في انتصار أُمته.

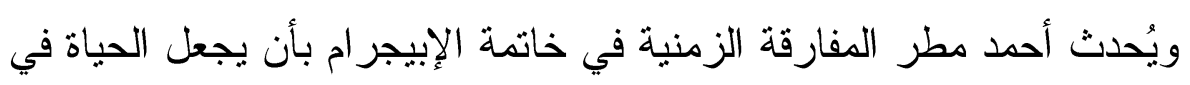

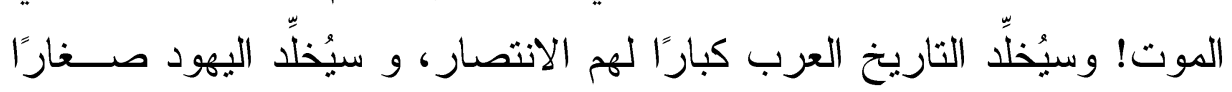
عليهم الصنَّار ! و إذا تشبث الثاعر بزمن القَصَاصِ أحيانًا فقد تنتابه لحظات مــن الإحبـاط

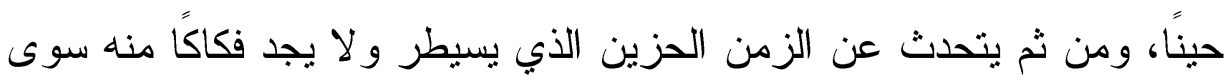

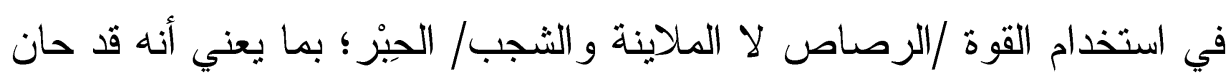

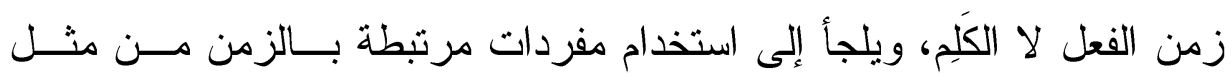

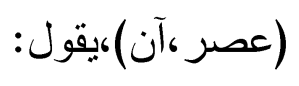

آه با عصر القصاصن

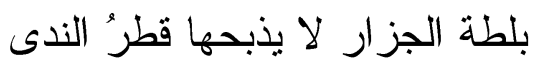
لا مناصن آل آنز

$$
\text { آن لي أن أترك الحبر }
$$

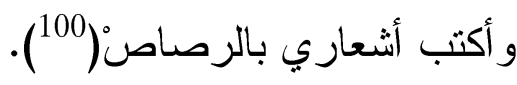


وقريب من هذا المعنى السابق قوله في هذا الإبيجر ام الآتي، وما يداخلــهـ

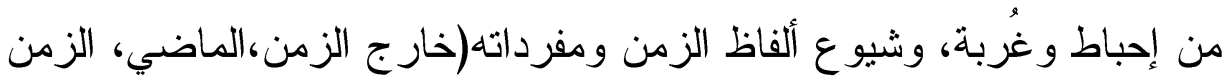

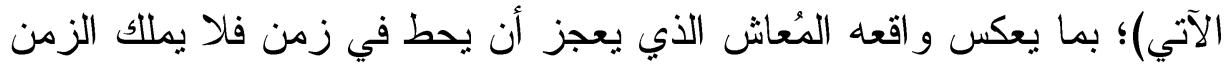

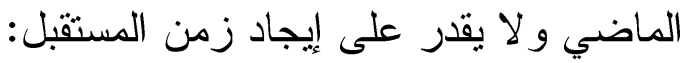
-

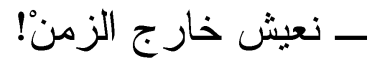

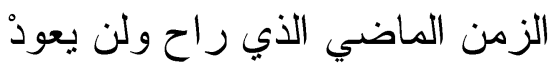

$$
\text { و ليس لله وجود الآتي الذي (101). }
$$

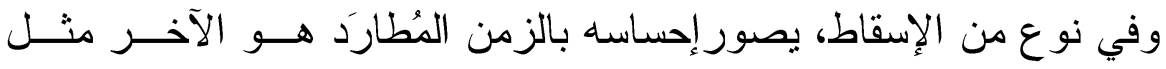

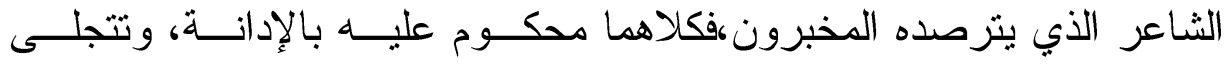

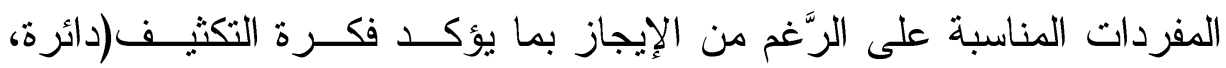

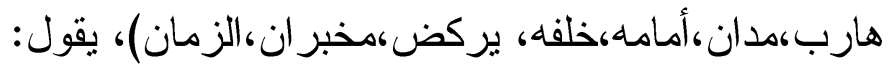

$$
\begin{aligned}
& \text { دائرة ضيقهُ } \\
& \text { و هارب مدان } \\
& \text { أمامه وخلفه } \\
& \text { يركض مخبر ان } \\
& \text { هذا هو الزمان (102). }
\end{aligned}
$$

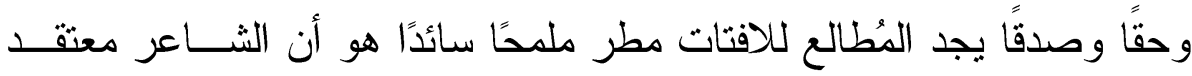

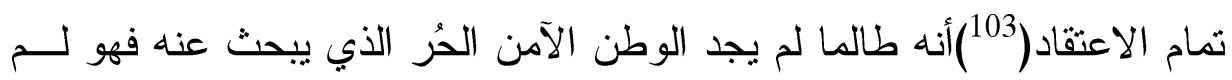

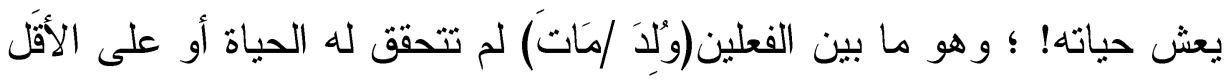

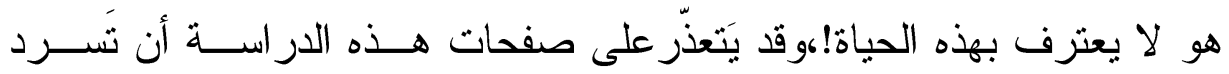

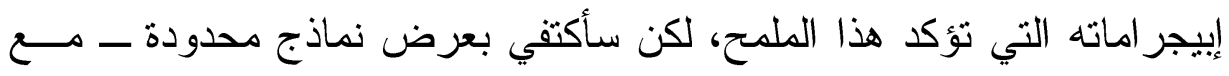




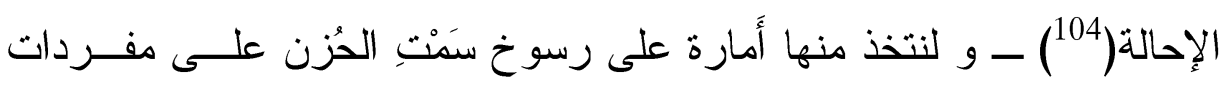
الزمن لديه للارجة التي استغرقت عُمره كله ــ على حد تعبيره ــ يقول: وفي أوطاننا

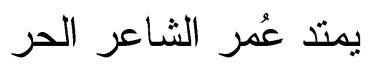
إلى أقصاه بين الرَّحم و القبر على بيت من الثَّعر !(105).

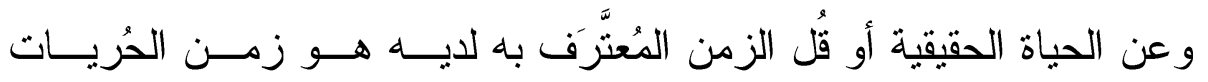

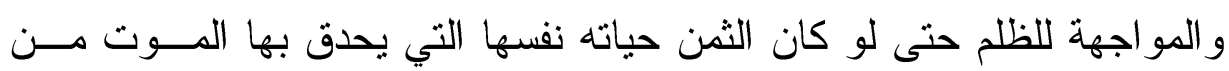

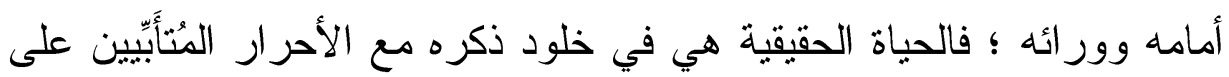

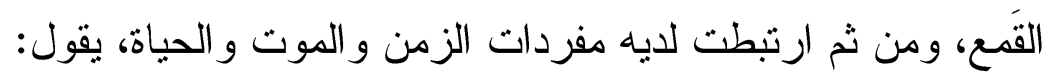

$$
\begin{aligned}
& \text { مشى الموت أمامي } \\
& \text { ومشى الموت ور ائي } \\
& \text { لكن قامت } \\
& \text { بين الموت وبين الموت } \\
& \text { حياة إبائي.( (106). }
\end{aligned}
$$

و في الإبيجر ام الآتي يلهث بك كما تلهث الحال به للارجة التي لا يحـدد

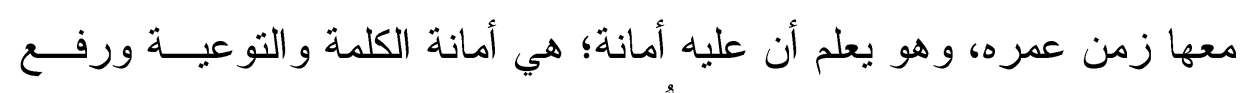

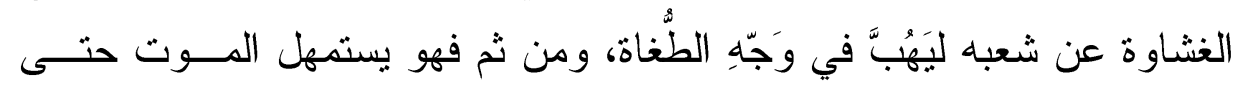

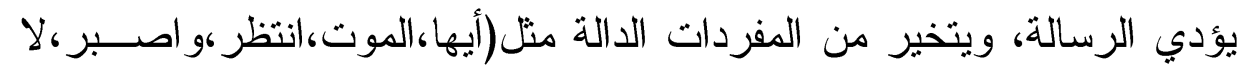

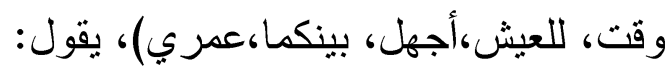
أيها الموت انتظر

$$
\text { فأنا لا وقت للمبر علي. }
$$

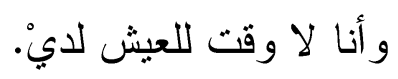




$$
\text { إنني بينكما أجهل عمري.(107). }
$$

وفي الإبيجر ام الآتي يجسد إحساسه بالأسى على هذه الحياة التي يحياها في

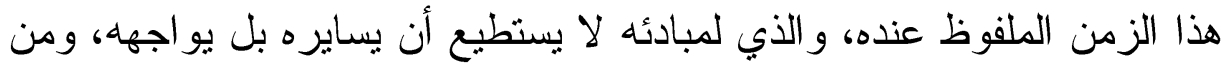

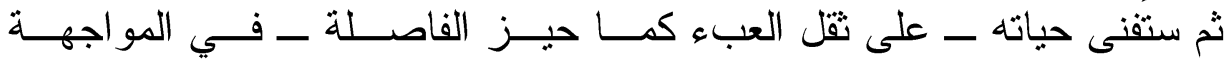
و الملاحقة ولن يعيش الحياة الو ادعة الناعمة، و مجمل إيبجر اماته تنطلق مـن

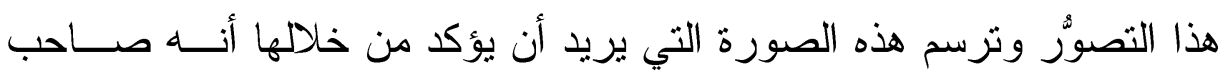

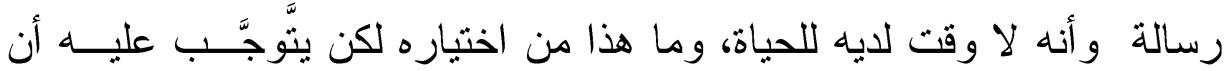

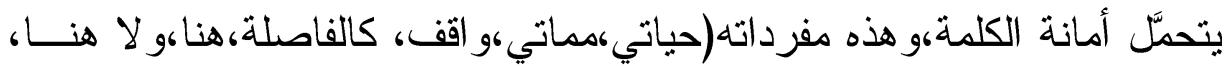
أضيع، ما بيني،وبيني)، يقول:

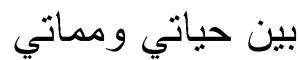
و اقف كالفاصلهُ. لست هنا... و لا هنا أضيع ما بيني وما بيني أنا! (108 (10).

\section{3 ـ مفردة الموت ومر ادفاتها:}

الموت هو الحقيقة الأكيدة المتكررة منذ بدء الخليقة حتى منتهاهــا، وعلـى الرغم من حتمية الموت فبعض الناس في الغالب لم يتقبل بسلاسة فكرة الانتهاء

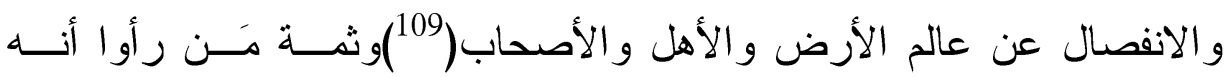

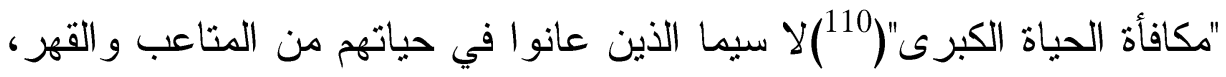

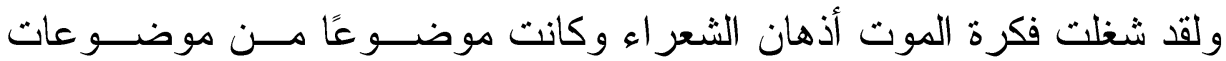

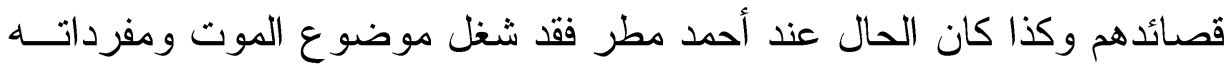

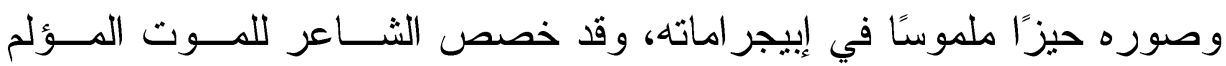

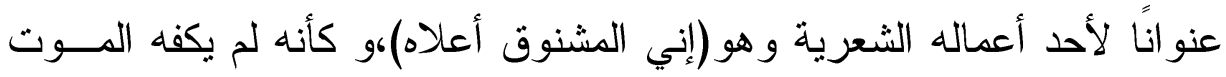

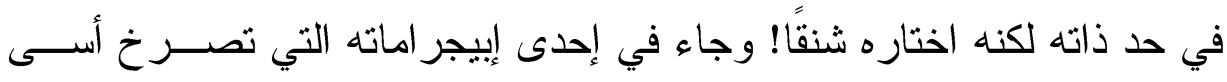

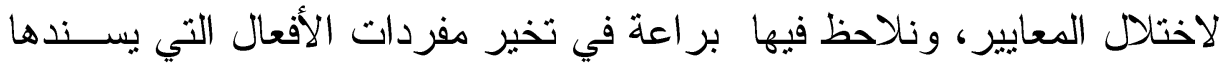




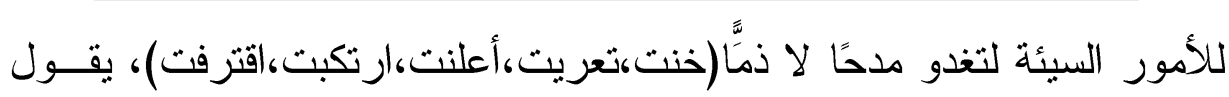

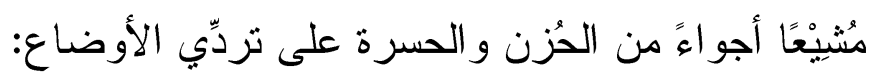

$$
\begin{aligned}
& \text { إنني المشنوق أعلاه } \\
& \text { على حبل القو افي } \\
& \text { خنت خوفي وارتجافي } \\
& \text { وتعريت من الزيف } \\
& \text { وأعلنت عن العهر انحر افي التي }
\end{aligned}
$$

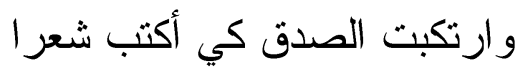

$$
\begin{aligned}
& \text { و اقترفت الشعر كي أكتب فجرا (111) }
\end{aligned}
$$

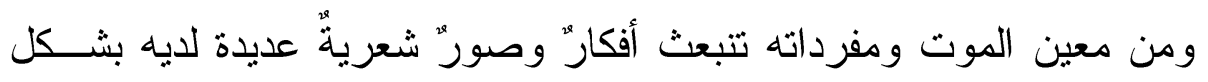
مُلفِت ــ قد يستدعي در اسة فنية تقوم على تتبع هذا الملمح ودو اله في أثـــعاره

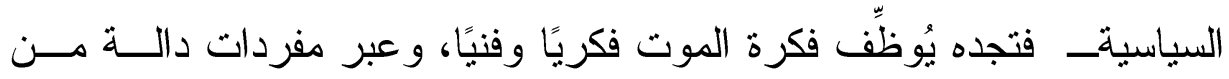

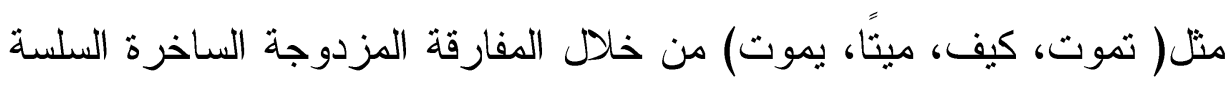

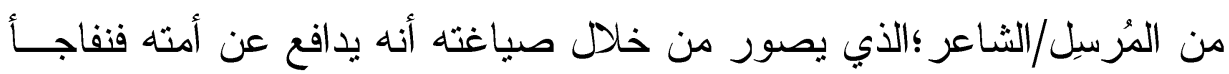

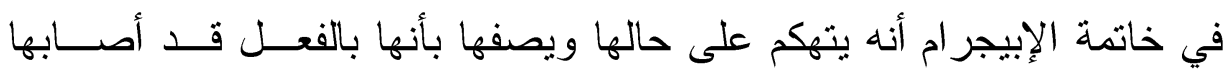

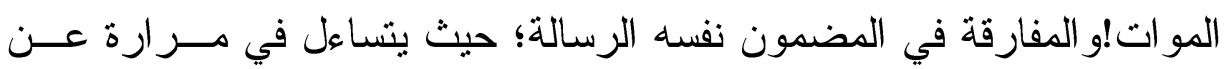

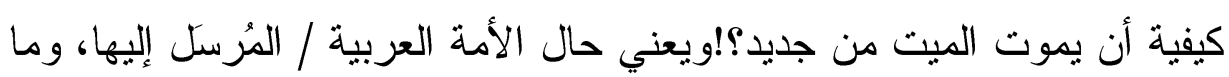

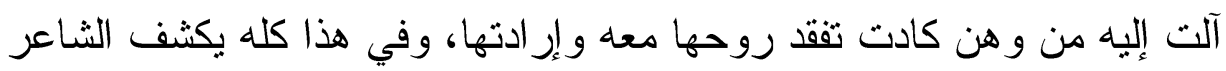

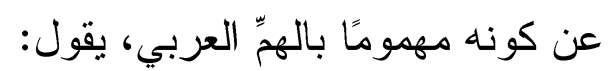

$$
\begin{aligned}
& \text { لا.. لن تموت أمتي } \\
& \text { كيف تموت؟ } \\
& \text { من رأى من قبل هذا ميتًا } \\
& \text { يموت من جديد.(112). }
\end{aligned}
$$




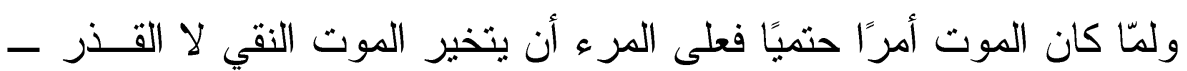

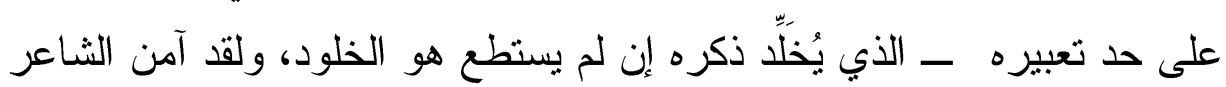

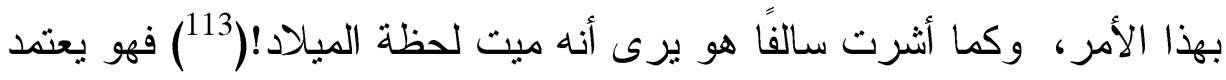

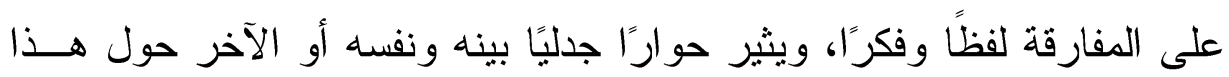

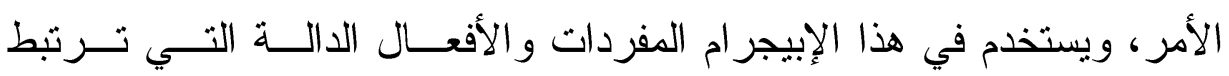

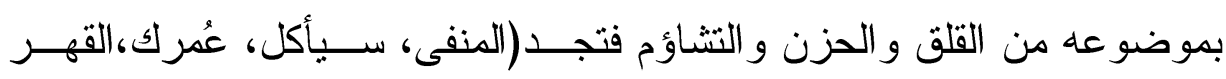

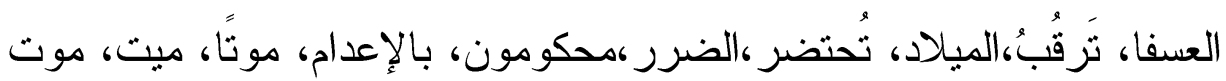

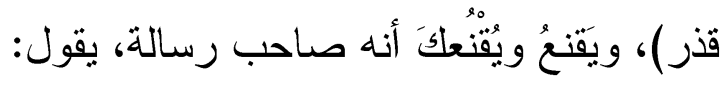

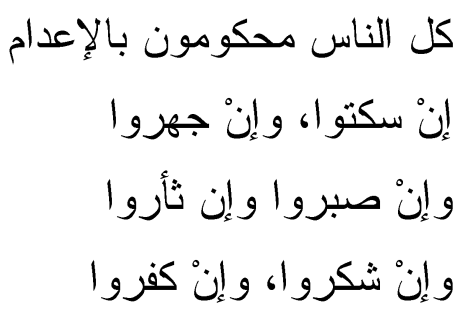
إنتقي موتًا نقيًا

$$
\text { و الذي بالكنب يحيا }
$$$$
\text { ميت أيضًا }
$$

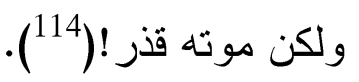

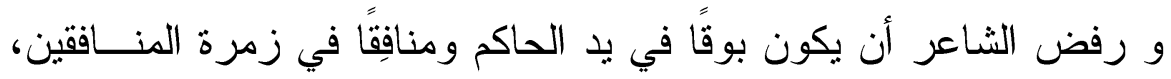

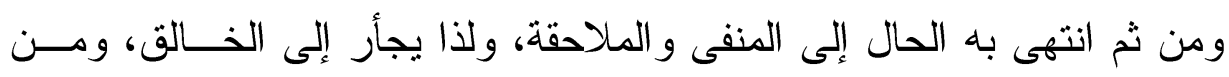

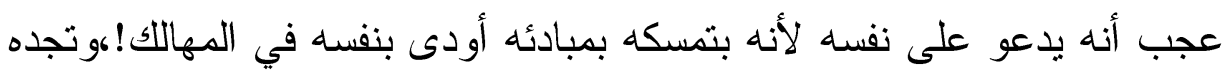

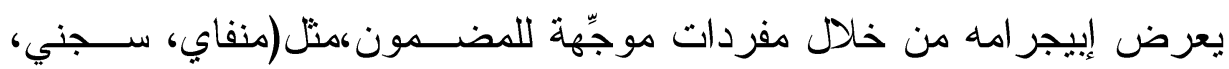
أنقذني، خلصني، طبل، يحبا،الأموات)، يقول:

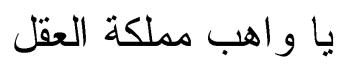
مملكتي منفاي وسجني. أنقذني.. خَلِّني مني. 


$$
\begin{aligned}
& \text { فأنا لست بطبل }
\end{aligned}
$$

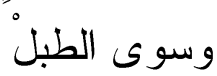

$$
\begin{aligned}
& \text { لا يحيا إلا الأموات! (115). }
\end{aligned}
$$

ويصنِّف في إبيجر امه الآتي الموتى في الوطن العربي ؛ وجميعهم ينــدرج تحت صينف الموت السياسي، وتأني مفرداته محددة ومعبره عن رؤيته السياسية

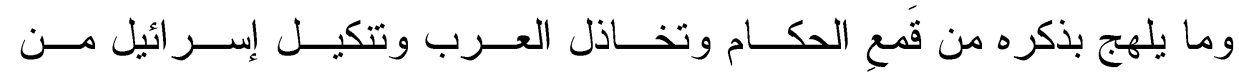
مثل(أموات، في أوطاني،أصحاب الفيل، إسر ائيل، عربائيل، تتكيل،الكعبة، النيل، ونيل،

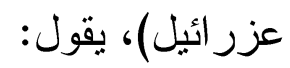

النّاس ثلاثة أمو ات

$$
\text { في أوطاني }
$$

و الميت معناه قتنيل

قسم يقتله" أصحاب الفيل" ولناه

و الثاني تقتله" إسر ائيل"

و الثالث تقتله " عربائيل"

$$
\text { وهي بلاد }
$$

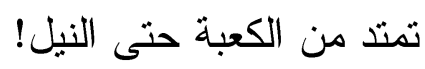

و الله اشتقنا للموت بلا تتكيل و الله اشتقنا...

أنقذنا با عزر ائيل(116)

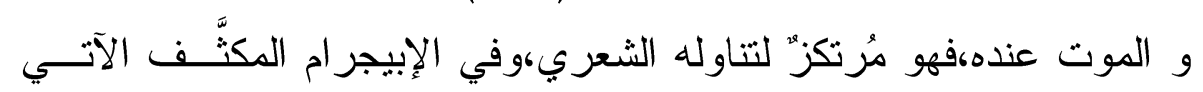

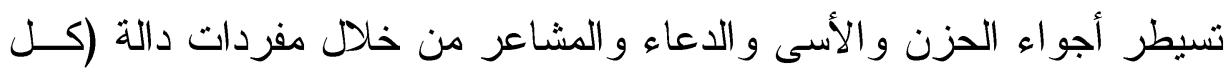
مَن، مَا، نهو اه، ماتهساعدنا، إحساسنا، أمت) يقول متهكمًا كدأبه: كل كَن نهو اه مات، نهو نهو اه مات. 
ربِّ ساعدنا بإحدى المعجز اتْ

$$
\text { و أمت إحساسنا يومًا }
$$

لكي نقدر أن نهوى الو لاه! (117)

من و اقع الإبيجر امات المخصوصة بمر ادفة الموت حاول الثـاعر أن يبــرز

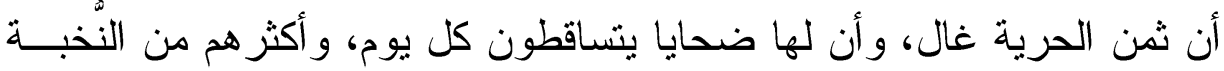

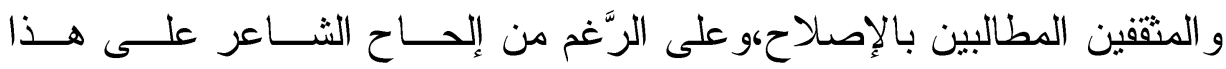

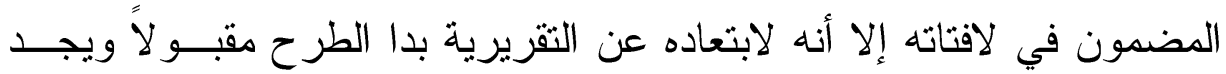
المتلقي نفسه متفاعلاً مع خِطابه. 4ـ مفردات المكان:

يُعد المكان مكوِّنًا رئيسًا من مكونات النَّص الأدبي(118)،و يبــرز المكـــان

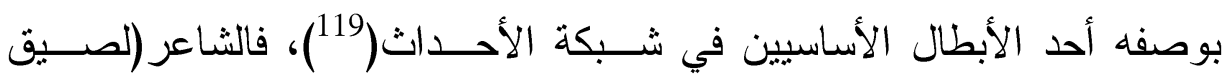

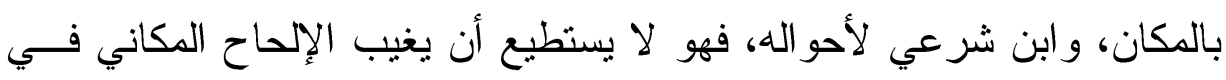

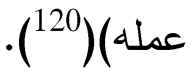

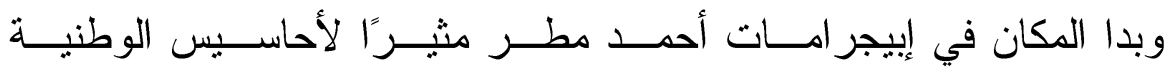

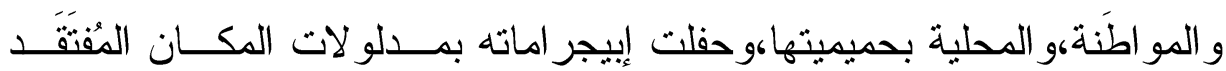

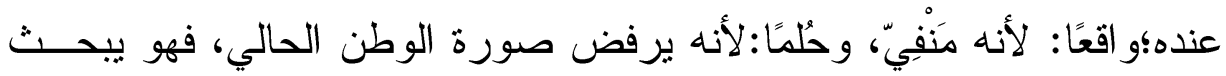

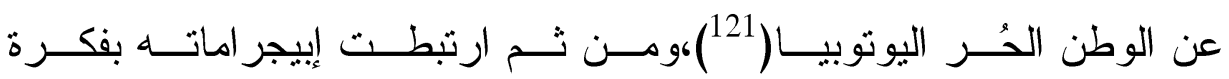
المكان/الذكريات الذي يرثى له لفقدهأو المكان/الملفوظ بأحو اله المتردية فيتهكم

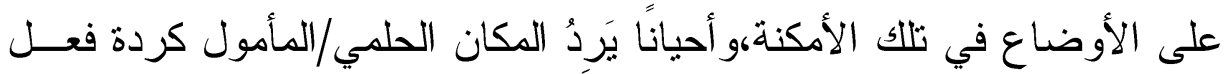
ضــــــ الو اقع المرفوض" هذه الأمكنة التي تتمظهر في الثعر العربي المعاصر

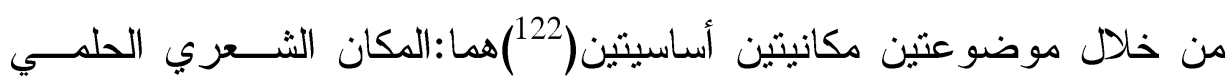

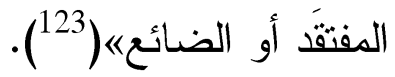
و أكثر الثاعر من ذكر كلمات الوطن،و البلد،والبلاد،وكذا ذكر أسماء البلدان

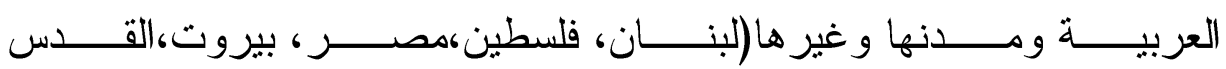




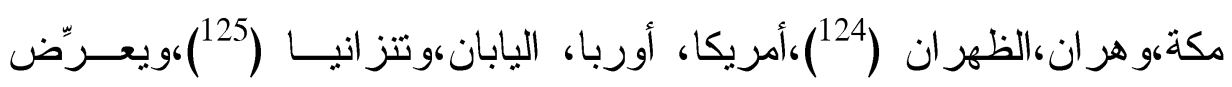

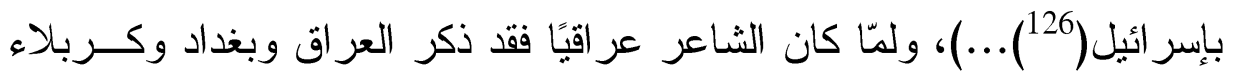

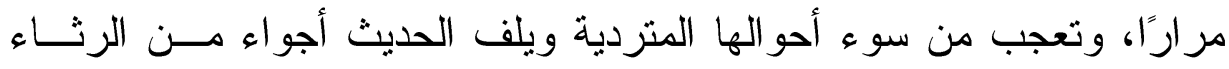

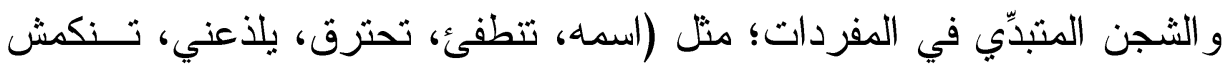

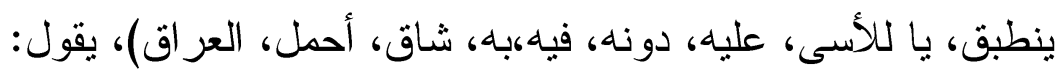
حين أطالع اسمه... تنطفئ الأحداق

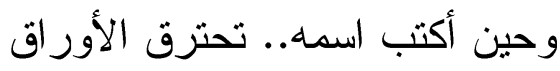

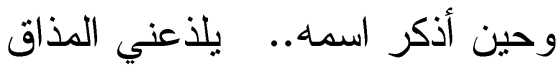

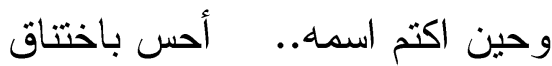

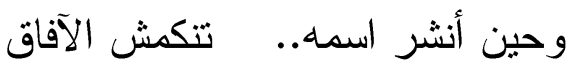
وحين أُطبق اسمه... بنطبق الإطباق

يا للأسى منه، عليه، دونه، فيه، بها

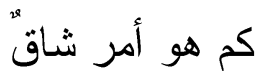

$$
\begin{aligned}
& \text { أن أحمل العر اق!!(127) }
\end{aligned}
$$

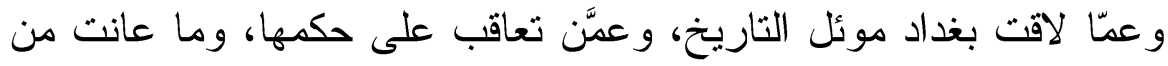
جور حتى آلت إلى ما آلت إليه من موات ودمار، يأخذك إلى المفارقة في أنها

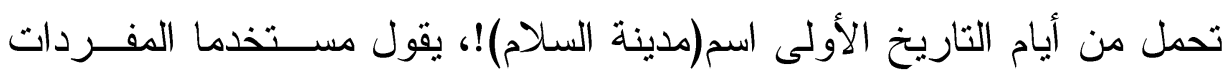

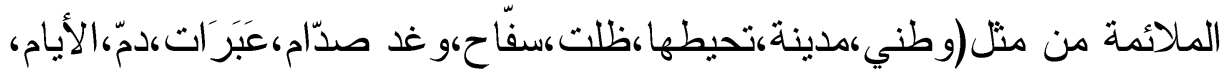
عظيمة،عظام، سلام): في وطني مدينة.. ظلَّت لألف عامْ

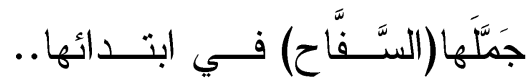
وز انها في المنتهـــ(صــدَّام)! و استو عب القوســان ما بينـــــا

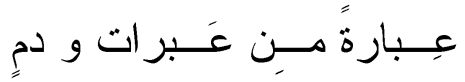




$$
\begin{aligned}
& \text { يدعــــهـا: الأيكــــــامْ! ... } \\
& \text { مدينة عظبمةُ }
\end{aligned}
$$

من فرط ما تحمل من هياكل العِظام.

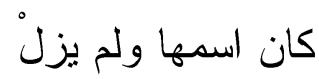

(مدينة السَّلام)( $)$

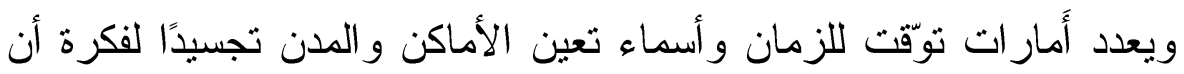

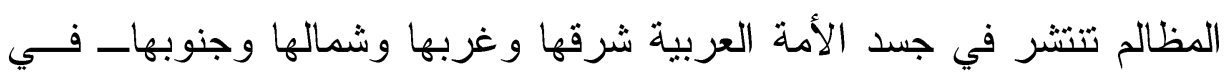

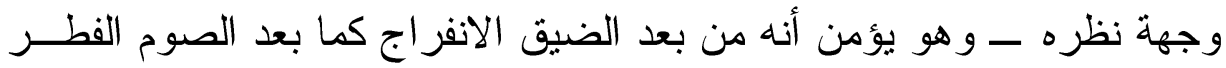

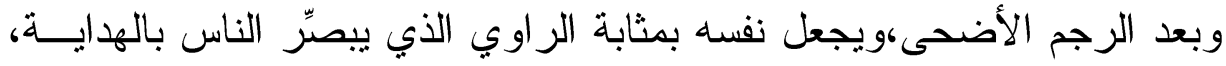

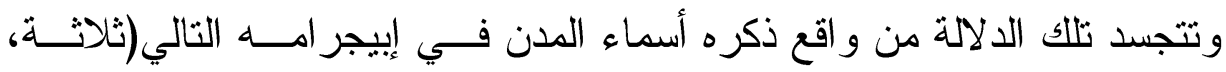

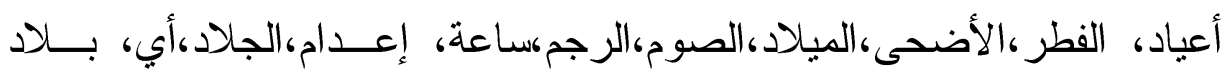
تونس، تطوان، صنعاء، عمّان، مكة، صنعاء، بغداد)، يقول:

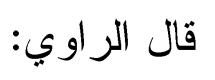

للناس ثلاثة أعيادُ

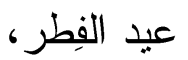

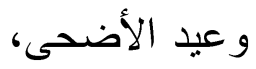
و الثالث عيد الميلاد.

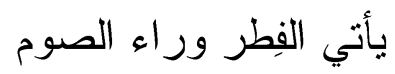
ويأني الأضحى بعد الرَّجمٍ ولكن الميلاد سيأتي

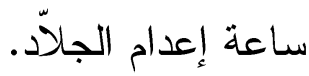

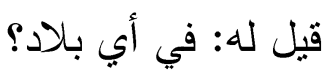

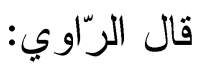
من تونس حتى تطوان 


$$
\begin{aligned}
& \text {.. } \\
& \text { قُتل الرّّاوي. } \\
& \text { لكنَّ الر اوي يا موتى لري } \\
& \text { علّمكم سرَّ الميلاد. (129) }
\end{aligned}
$$

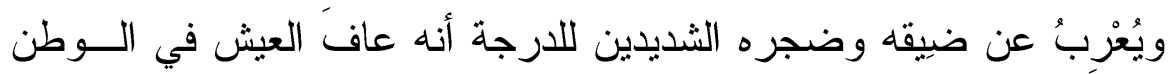

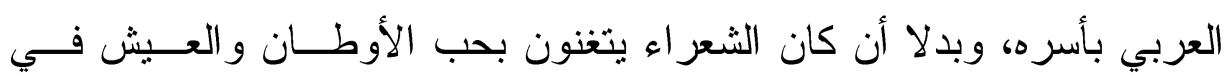

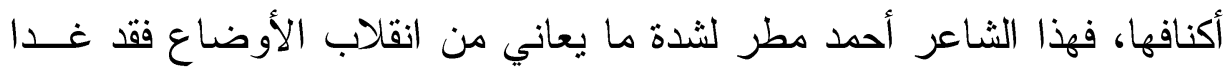

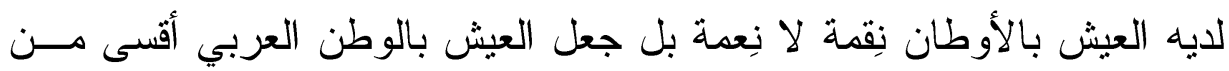

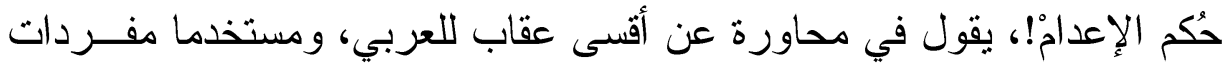
معبرة من منل (الإعدام، أخف،الفرد، العربي، أهنالك، أقسىى): ـ الإعدام أخف عقابٍ

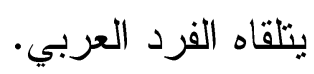
- ـ أهناللك أقسى مين هذا؟

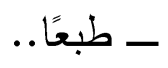

فالأقسى مِن هذا

$$
\text { أن يحيا في الوطن العربي! (130). }
$$

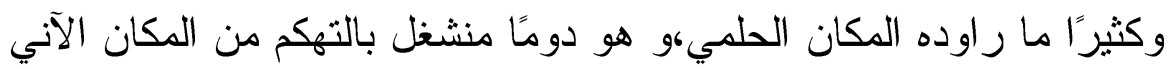

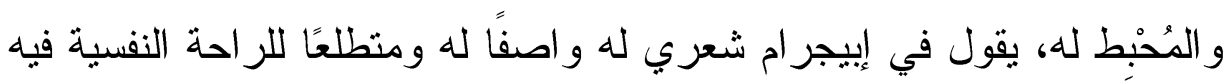

$$
\begin{aligned}
& \text { - حتى لو كان صريفة(131) - يقول: } \\
& \text { لأني وميض" يُّ" } \\
& \text { و ؤني مطرْ. } \\
& \text { غدًا حين تُطوى سطور الصحيفة } \\
& \text { ويقضي الخليفةٌ }
\end{aligned}
$$$$
\text { وينسى الأثيرُ مكان الأثَرْ }
$$ 


$$
\begin{aligned}
& \text { ستروي السبّرُ": } \\
& \text { هنا شاعر قائم في صريفهُ } \\
& \text { نظيف مقيم بدنيا نظيفهُ! (132). }
\end{aligned}
$$

ويؤكد على الوجود الافتراضي للوطن أو المكان الحلمي الذي فيه مبادئ

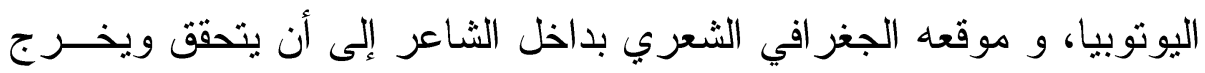

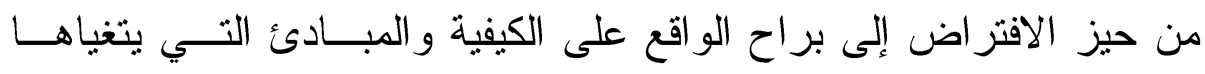

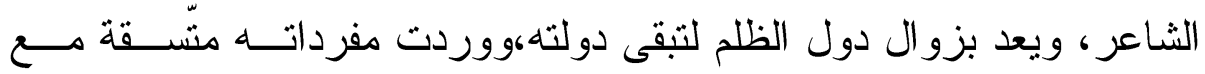

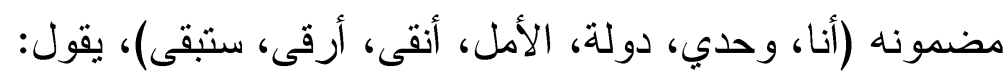

$$
\text { أنا وحدي دولة ودي، دوله، }
$$

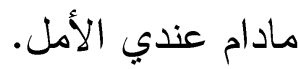

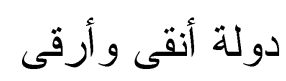

$$
\text { حين تفنى الدولى (133) }
$$

ومن ألفاظ الأمكنة التي تكررت بشكل و اضح هي( القبور)، و استخدمها على لهار معناها الحقبقي و المجازي، من مثل قوله:

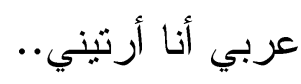

$$
\begin{aligned}
& \text { شقي لي قبرًا... و واخفيني } \\
& \text { ملَّت من جُبني أوردتي... (134). }
\end{aligned}
$$

\section{5ـ المفردات العامبة والأجنيبة:}

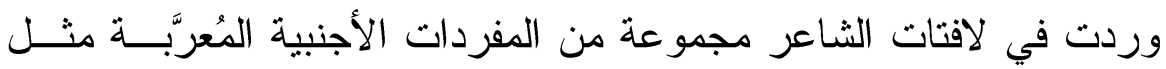

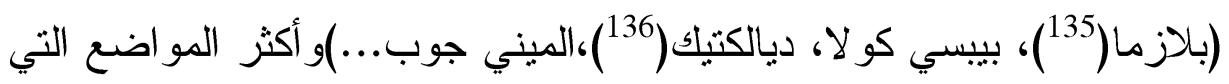
وردت فيها مثل هذه المفردات العامية كانت في سياق تهكم الثاعر من الحكام وكانت وسيلة دعائية ضدهم، وسخرية من الذين يعيبون عليه دفاعه عن حقوق 
الشعوب، ويسخرون من نضاله، ويطالبونه بالانشغال بالقضايا التافهة النـي لا تفيد الثعوب و لا الأجيال ؛ يقول:

$$
\begin{aligned}
& \text { ر بنا. .هل نحن من ماء مهين }
\end{aligned}
$$

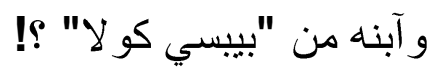

$$
\begin{aligned}
& \text { ربّنا. ـهل نحن من وحل وطين من لين }
\end{aligned}
$$

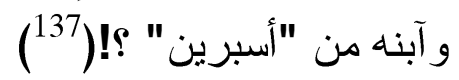

وثمة إبيجر امات أخرى حملت مفردات أجنبية مكتوبة بالحروف الإنجليزية،

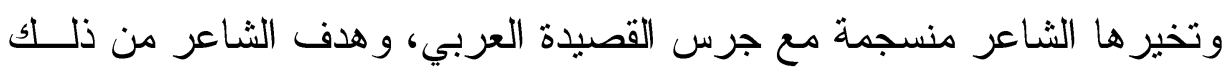

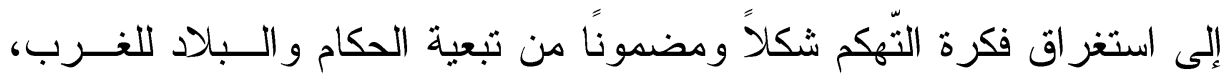
يقول: وشعوب مثل الأشباح تقتات بقايا الأرواح

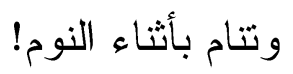

Who are they?-

\section{Don't mention them}

$$
\text { قومك هم أولى بالذّم }
$$

وبذلك يؤكد مبحث بنية المفردة ما هو راسخ من كون المفردة » لا تحمـلـل

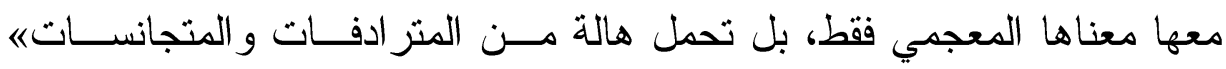
(139) هوبذا تظل اللغة في تطور متجدد(140)، وتصبح أداة التعبير الرئيسة في يد المبدع.

\section{[ب] بلاغة التر اكيب في الإبيجر ام عند أحمد مطر:}

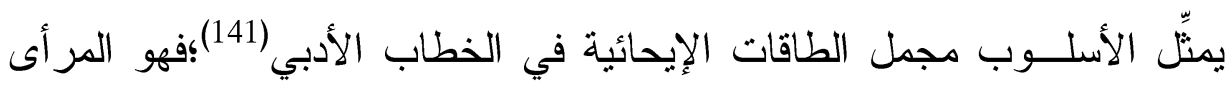
الظاهري لإبداع الأديب، وهو وسيلته إلى المتلقي عن طريق صوغه في جمل 
و عبار ات، يُر اعي فيها تحقيق ما ينبغي من نسج الصور الجزئية(142)،وتتبـاين

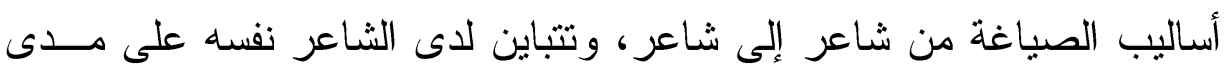

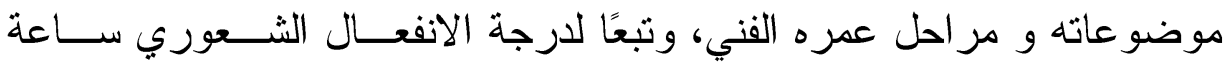
الإبداع.

ومعلوم أنَّ الشاعر لا بستخدم اللغة لأنه يريد التوصيل الاعتبادي لكن لأنــهـ

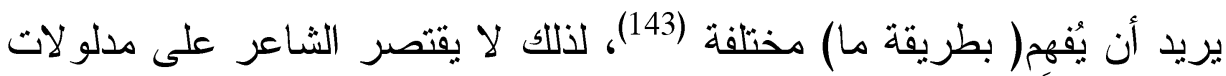

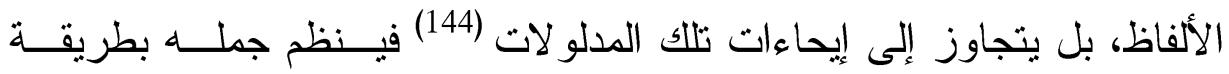

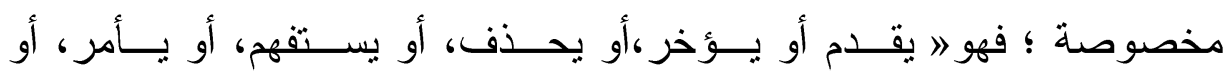

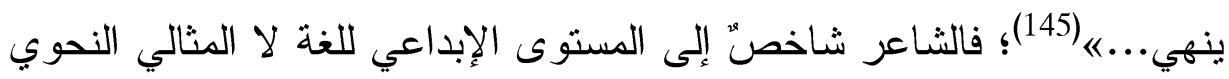

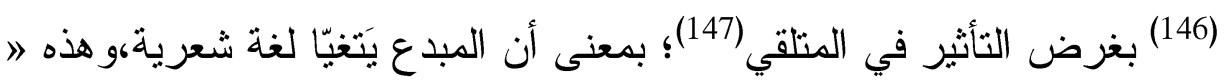
اللغة الشعرية الجديدة هي التي تجتهد لتكون لغة خلق جديدة ليست مجرد وسيلة

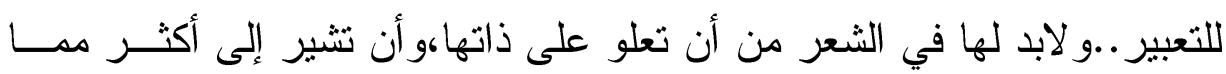
تشير إليه ؛ فهي إذاً لغة الإشارة «(

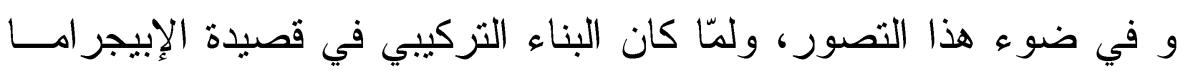
يمثل قو امًا رئيسًا، فقد انعكس هذا الملمح بجلاء في لافتات الثاعر ، و و سأحاول

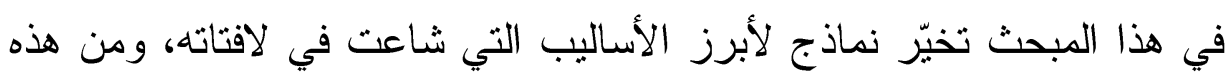

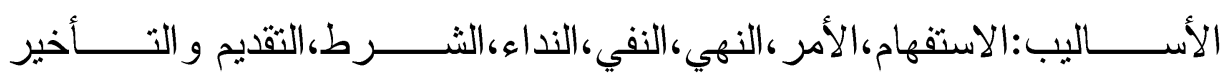
و الحذف..إلخ.

\section{1- الاستضفهام:}

والاستفهام أحد الأساليب اللغوية، و البنَى التركيبية التي قد يستعمها ليرقـى

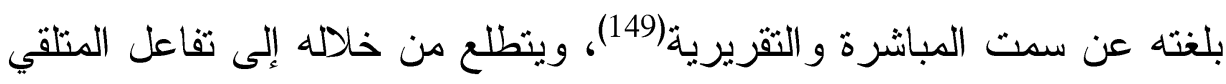

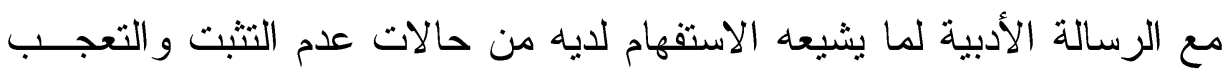

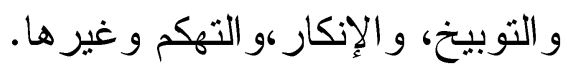


و أسلوب الاستفهام شائع بصورة ملفتة في لافتات الشاعر عمومًا وفي خاتمة الإبيجرام على وجه الخصوص؛ لأنه أراد أن لا يُغلق القضية/الرسالة بل يفتح

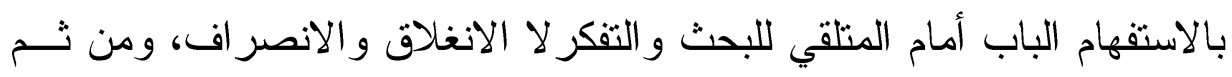

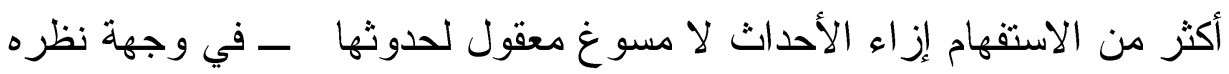

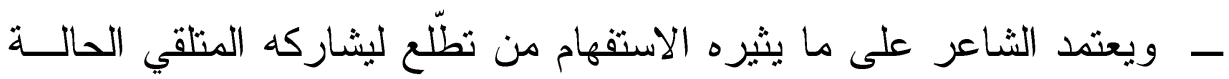

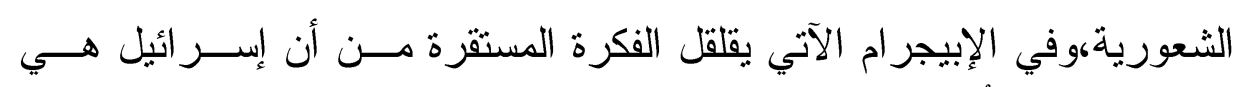

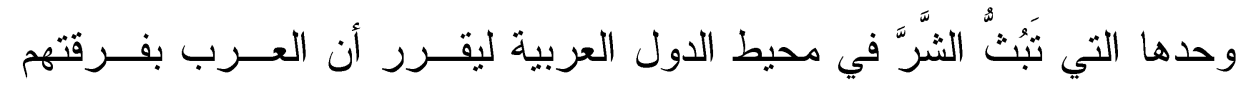

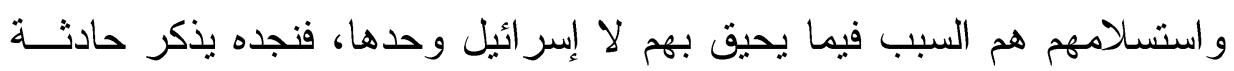

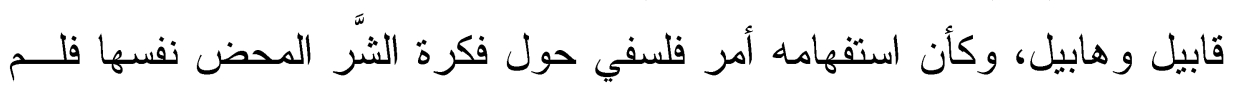
يكن اليهود قد خُقو ا وقتها، وفي ذلك يقول:

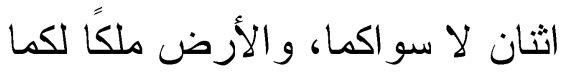
لو سار كل منكما بخطوه الطويل

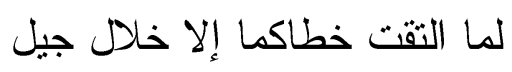
فكيف ضاقت بكما فكنتما القاتل و القتيل قابيل... يا قابيل لو لم يجئ ذكركما في محكم التنزيل لقلت: مستحيل!

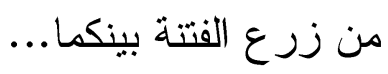
ولم تكن في الأرض إسر ائيل ؟!(150).

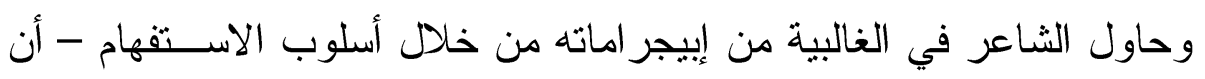

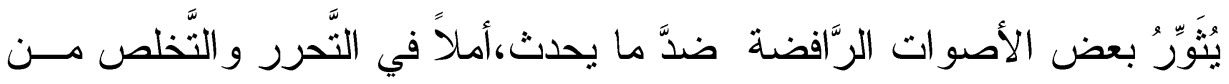

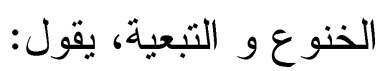
نحن من أين؟ إلى أين؟ 


$$
\begin{aligned}
& \text { وماذا؟ ولماذا؟ } \\
& \text { نظم محتلة حتى قفاها } \\
& \text { وشعوب عن دماها مستقله! }
\end{aligned}
$$

نحن لغز معجز لا تستطيع الجن حله.((151)

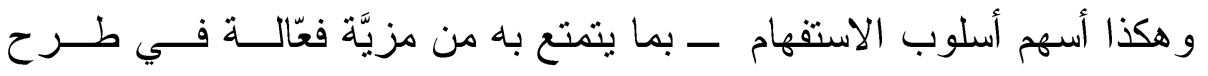

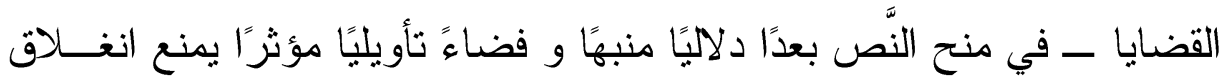

$$
\text { النص على الرغم من انتهائه(152). }
$$

وقد يخرج أسلوب الاستفهام - عند الثاعر - إلى أغراض مجازية أخــرى منها؛ النفي والازدراء، كقوله:

كيف يصطاد الفتى عصفوره

في الغابة المشتعلهُ ؟ كئ

$$
\text { كيف يرعى ورده }
$$$$
\text { وسط ركام المزبله ؟ ونه }
$$

كيف تصحو بين كفّبه الإجابات

وفي كفيه تغفو الأسئلة ؟!

$$
\text { الأسىى لا حدّ له }
$$$$
\text { و الفتى لا حول له له له له له }
$$$$
\text { إنه يرسف بالويل }
$$

فلا تستكثرو إسر افه في الولوله

$$
\text { ليس هذا شِيعره }
$$

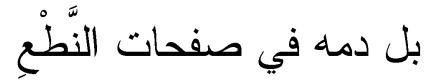

مكتوب بحدِّ المِقْصَهة (153).

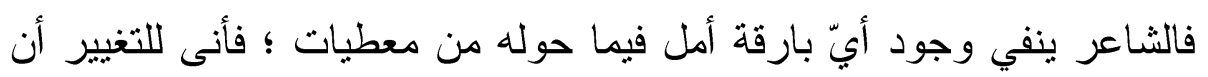

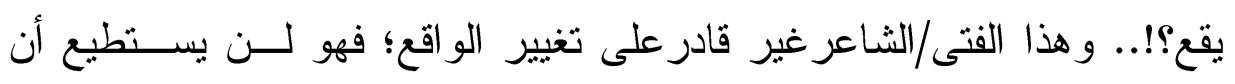


يصطاد عصفورًا، وهل هنالك عصافير في غابة مشتعلة؟!اولن تُخْرِجَ أجــواء

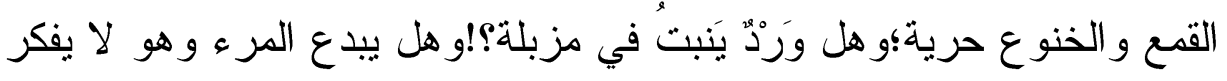

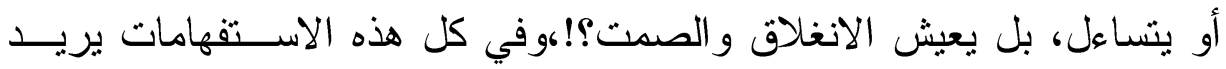

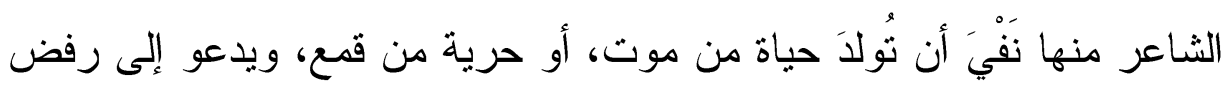
هذا الو اقع المُزْري.

ومن الاستفهام ما ينصرف إلى التوبيخ، ومثال ذلك قوله:

$$
\begin{aligned}
& \text { إن كان الغرب هو الحامي } \\
& \text { فلماذا نبتاع سلاحه؟ } \\
& \text { و إن كان عدوًا شرسًا } \\
& \text { فلماذا ندخله السّّاحةٌ؟! (154) }
\end{aligned}
$$

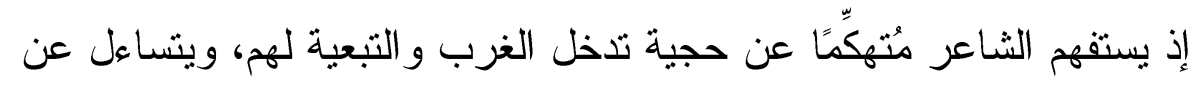

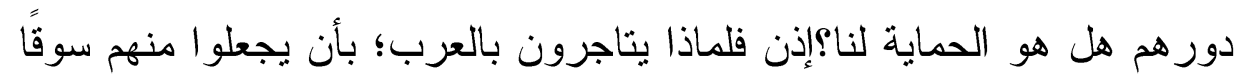

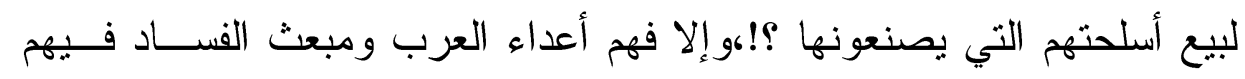

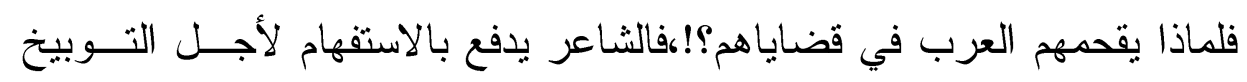

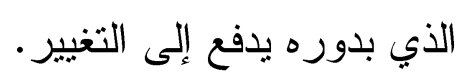

ومن الاستفهام ما ينصرف إلى التحقير،ومنه هذا الإبيجر ام و يقول فيه:

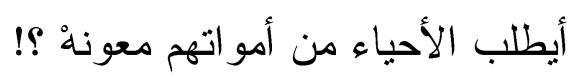

$$
\begin{aligned}
& \text { دعو ا صلاح الدين في تر ابه } \\
& \text { و احترمو ا سكونه } \\
& \text { لأنه لو قام حقًا بينكم } \\
& \text { فسوف تقتلونه (155). }
\end{aligned}
$$

فالثاعر يُحقِّر مين شأن مَن يطالب (صلاح الدين الأيوبي) بالنهوض من قبره

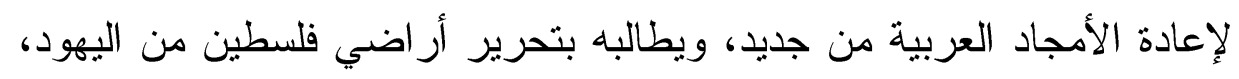

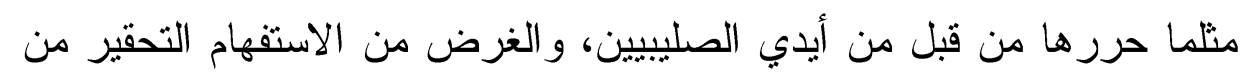




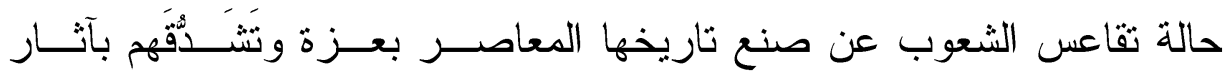

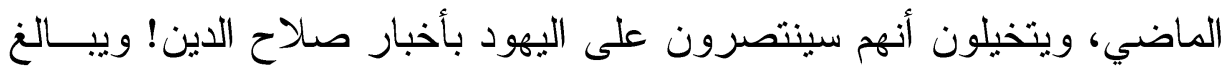
أنه لو قام فيهم صلاح الدين لما سلم منهم ولقتلوه!

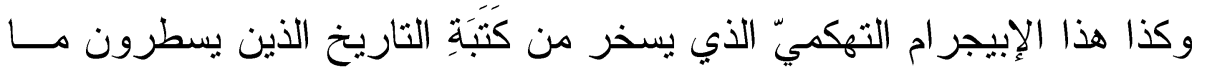

يُملَى عليهم من السلطات وتبعًا للعطايا، يقول فيه:

$$
\text { اسأل التاريخ }
$$

هل أقلامه إلا السكاكين؟

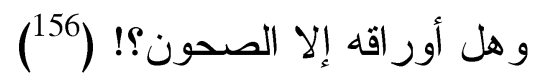

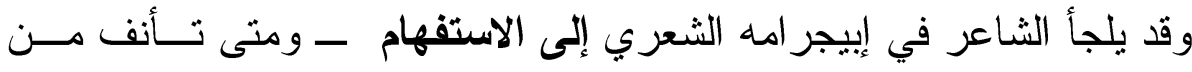

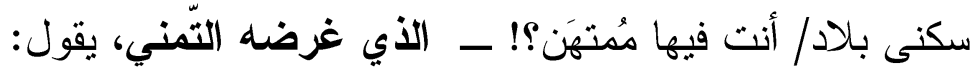
ـ أيها الحزن الذي يغشى بلادي

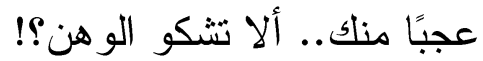

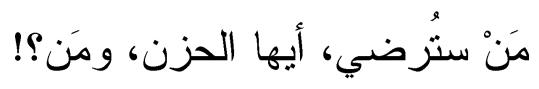

ومتى تأنف من سكنى بلاد

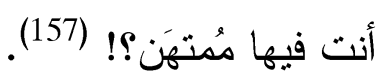

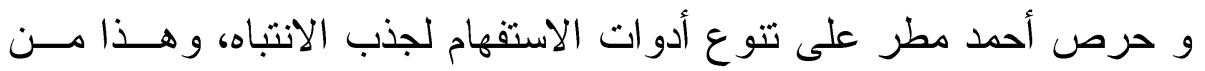

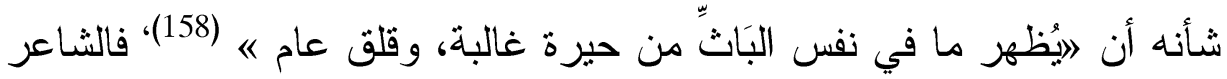

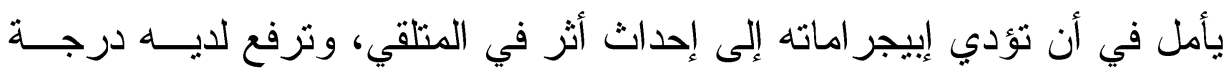
الانفعال و الوعي ليتخلص من قيوده.

$$
\text { : } 2
$$

لجأ الثاعر إلى هذا الأسلوب ليظهر اعتداده بنفسه بما يُمكنهاه من إصـــدار

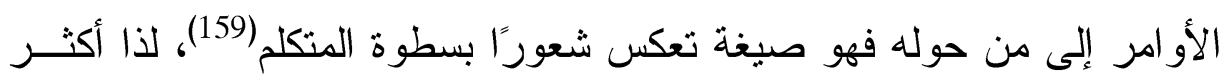
من استعماله بمعناه الحقيقي كقوله: أنا سلطان السلاطين 


$$
\text { و وأنتم خدم للخدم }
$$

فيفتخر الثاعر بنفسه لدرجة أن نَصَّب نفسه سلطان السلاطين - ير اهم خدم

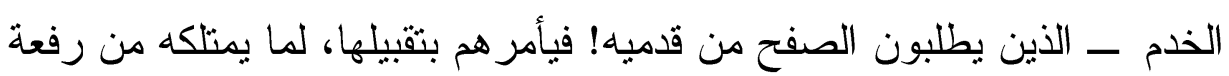
في مقابل انحطاط هؤ لاء الحكام في نظره! ومن و اقع هذا الإحساس بارتفاع المكانة - الاستعلاء - أخذ الثاعر يصــدر

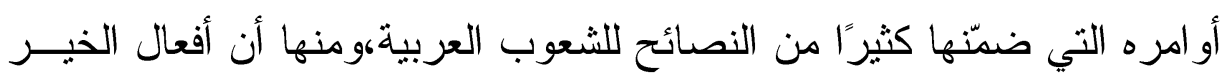

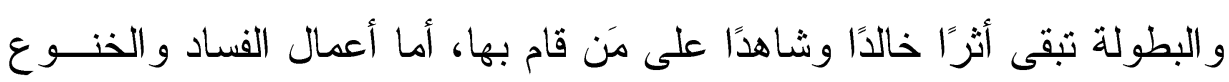

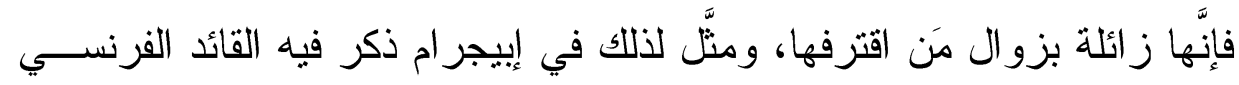

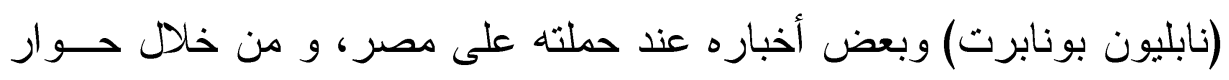

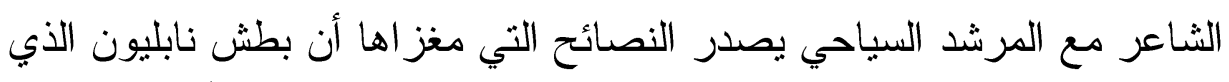

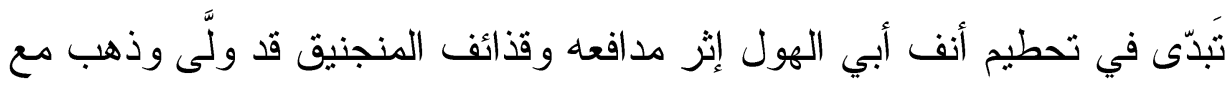

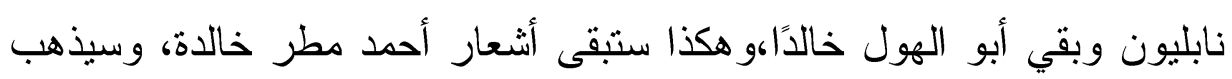

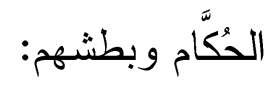

قال الاليل في حذر:

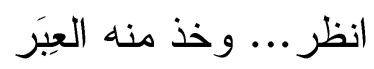

انظر ... فهذا أسد

له ملامح البشر

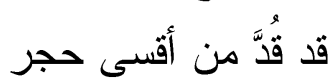

لكنَّه لم يعتبر

كان يدسٌ أنفه في كلّ شيء

فانكسر 


$$
\begin{aligned}
& \text { هل أنت أقوى با مطر ؟ } \\
& \text { كان (أبو الهول) أمامي } \\
& \text { أثرًا منتصبًا } \\
& \text { سألت }
\end{aligned}
$$

هل ظلَّل لمن كَسر أَنَفه... أثر ؟!|(161).

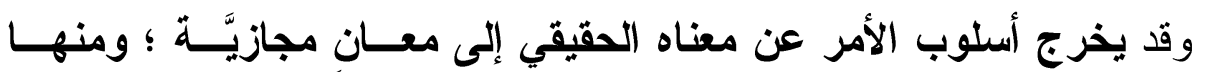

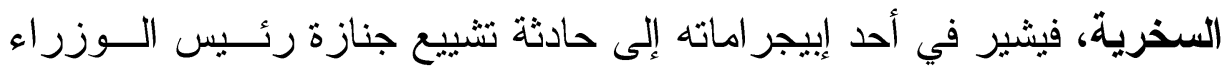
الإسر ائيلي (إسحق رابين)، وقيام بعض القادة العرب بالمشاركة فيها! ويرى في هذا التصرّرف تهاونًا ومذلَّة، يقول في محاورة وفئ إبيجر امية: ـ كيف أو اسي المرزوئين

بوفاة أخيهح (رابين) ؟

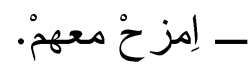
إمسحْ بالنكتة أدمعهم معنم

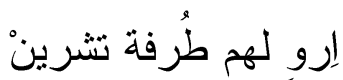
دَغْدِغهم بصلاح الدين

$$
\text { - }
$$

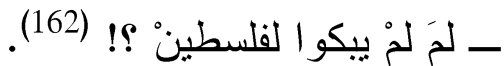

وقد يخرج الأمر في الإبيجرام إلى وجهة التهايد والمواجهة ؛حيث يتو عد كلَّ

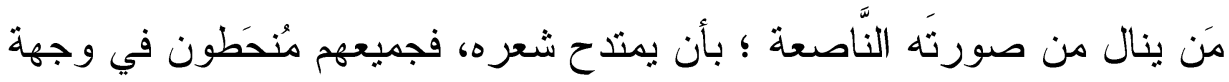

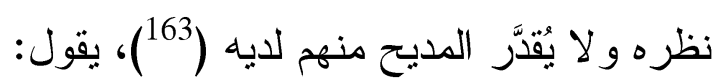

$$
\text { و و واشتنموني }
$$




$$
\begin{aligned}
& \text { فاحذروا أن تمدحوني } \\
& \text { احذروا أن تلطخوني }
\end{aligned}
$$

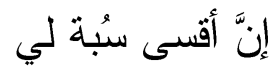

$$
\begin{aligned}
& \text { هي أن بمدحني } \\
& \text { نذل وقو اد ودوني! (164) }
\end{aligned}
$$

وقد يفيد الطلب لايه معنى الاعاء: ومنه قوله مخاطيًا وطنه:

$$
\begin{aligned}
& \text { سامحك الله على صلبي } \\
& \text { يا قاتلي } \\
& \text { كفاك أن تقتلني } \\
& \text { من شدة الحب (165) }
\end{aligned}
$$

فنجد الثاعر يدعو الله أن يسامح وطنه على سبيل العتاب لهذا الوطن الــذي على - حد تعبيره ـ قتل الثاعر لأنه يحبه ويصره" على إيقاظه!.

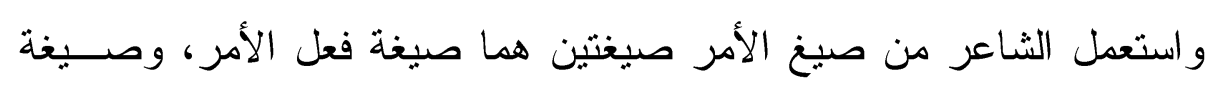

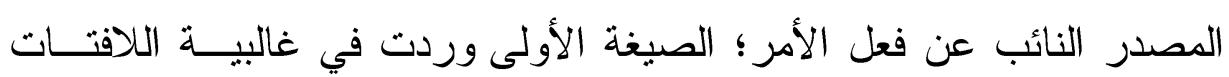

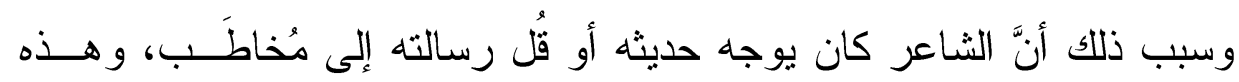
الصيغة مرنة في دفع هذا المخاطب إلى الاستجابة.

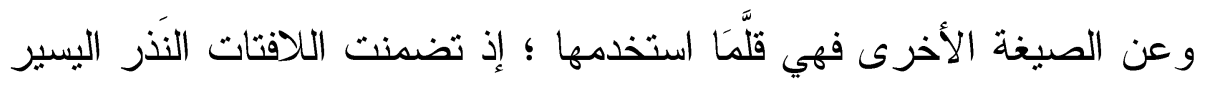
منها؛ مثل ما قاله في قصيدة يشير فيها إلى قرار الزَّعيم الراحل(أنور السادات)

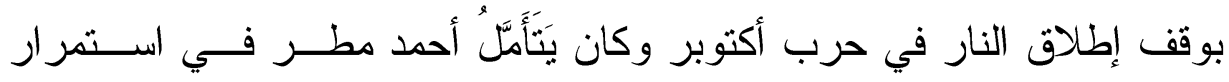

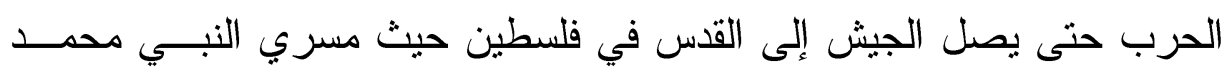

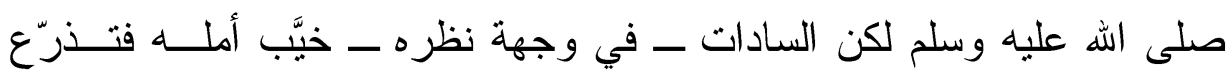

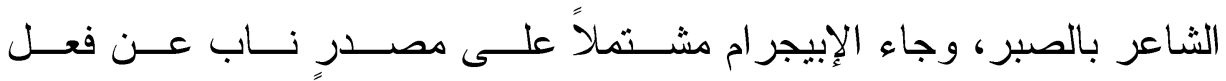

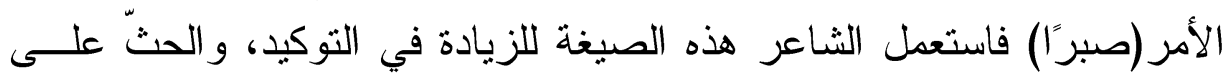


الفعل، و الإغر اء به(166) من لان القائد، ليُهِّأ من نشوة النصر ليقبــل الجــيش

$$
\text { بالهدنة - في وجهة نظر الثاعر - يقول: }
$$

بنينا من ضحايا أمسنا جسرًا

$$
\begin{aligned}
& \text { وقدَّمنا ضحايا يومنا نذرًا } \\
& \text { لنلقي في غد نصرًا } \\
& \text { ويمََّنا إلى المسرى عي عيد } \\
& \text { وكدنا نبلغ المسرى } \\
& \text { ولكن قام عبد الذات } \\
& \text { يدعو قائلاً: صبر أمبات } \\
& \text { فألقينا بباب الصبر قتنالنا } \\
& \text { وقلنا:أنَّه أدرى(167). }
\end{aligned}
$$

لقد كان لاعتداد الثاعر بنفسه الأثر الكبير في إكثاره من هذا الأسلوب، إذ أنَّه

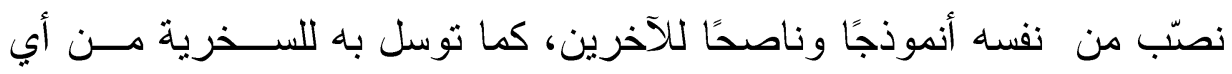

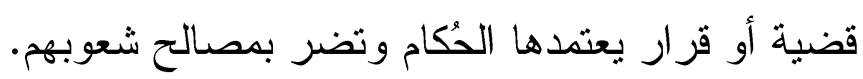

$$
\text { 3- النه: }
$$

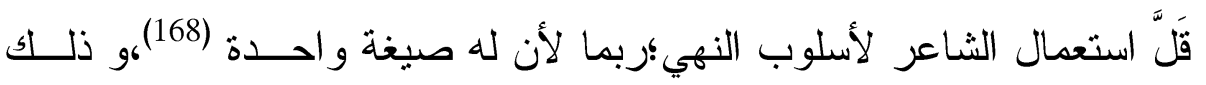

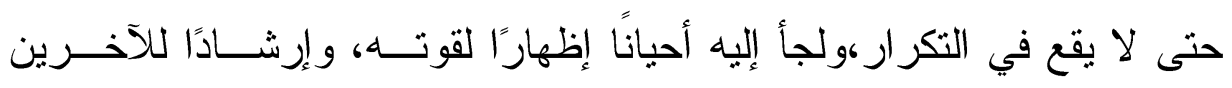

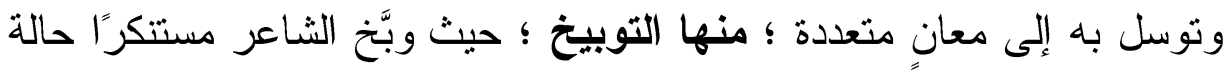
القمع و أجو اء الملاحقة في بلاده، يقول:

$$
\begin{aligned}
& \text { لا تسخروا مني فحتى القُبلهُ } \\
& \text { حادثةً في أوطانتا } \\
& \text { تمس أمن الدولهُ!(169) }
\end{aligned}
$$


وقد يكون أسلوب النهي لغرض النصح والإرشاد، يقول الثاعر الخبير فـي

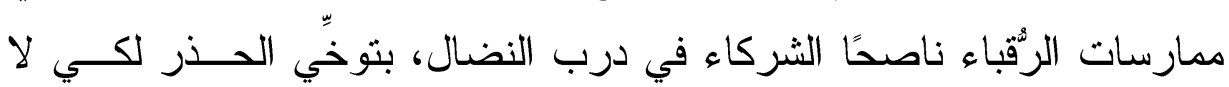

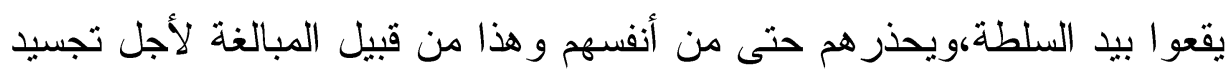
معاناة الشاعر في الواقع من الرقابة، يقول: لا تهاجر كل مَن حوللك غادر

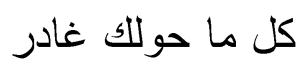
لا تدع نفسك تدري بنو اياك الدّقينة و على نفسك من نفسك حاذر (170).

معلوم أن أسلوب النفي يفيد النقض و الإنكار (171)، ويفيد في دفع المـلــلـ(172)

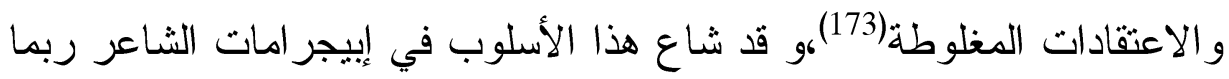

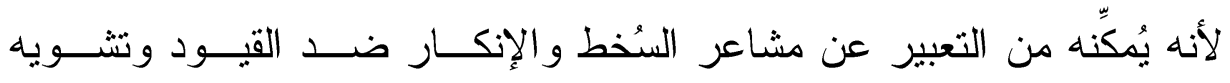

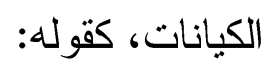

$$
\begin{aligned}
& \text { شعبي مجهول معلوم! } \\
& \text { ليس لله معنى مفهوم } \\
& \text { يتبنّى أغنية البلبل } \\
& \text { لكن... يتغنى بالبُوم } \\
& \text { يحيا موتًا }
\end{aligned}
$$

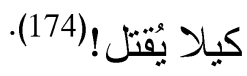

ويستتكر الشاعر على أبناء أمته التناقض ؛ فهم يشدون بأغنيات الحرية، لكنهم يخضعون لنسلّط الحاكم الظالم دون إباء؛. 
و اشتغل الشاعر على هذا الأسلوب كثيرًا لنفي المثالب ولفظهاهو إثبات المحاسن وتثبيتها،وكذا استخدمه لتثوير الثعوب ضد هد الطغاة، ويدعو من خلال التزميـز

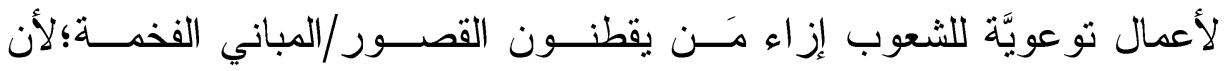

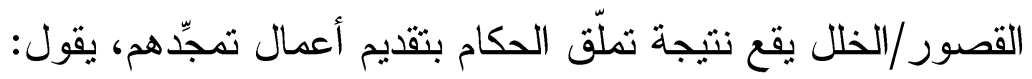

$$
\text { في المسرح المهور }
$$

ويسقط الممثل المشهور

ويسقط الجمهورْ.

لا عرض بعد اليوم بالمره

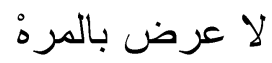

فغاية القُصور في الثورن بالثره

أن تُعرض الثورةٌ في القصور !(175)

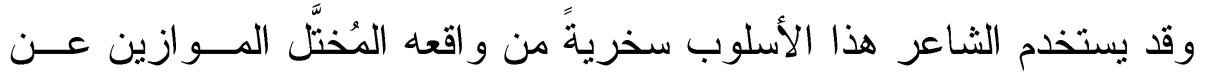

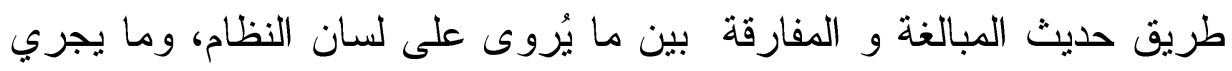

على أرض الواقع، كقوله:

وسلاطين بلادي

يتسلون بتضييع الملايين

وتجويع المساكين

وتقطيع الأيادي

ويفوزون

إذا ما أخطأو إنون

في الحكم

بأجر الاجتهاد،

عجبًا،

كيف اكتشفتم آية القطع 


$$
\text { ولم تكتشفوا، رغم العو ادي مدة من كل آيات الجهاد! (176) }
$$

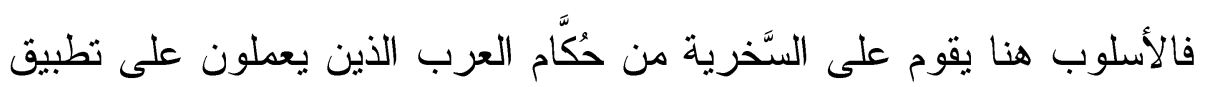

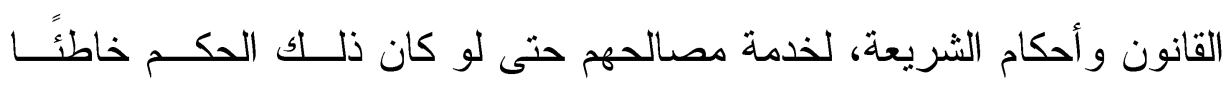

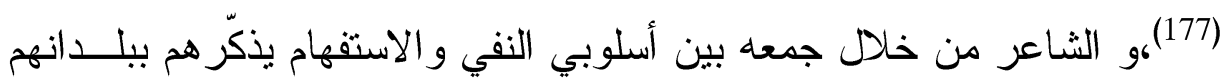

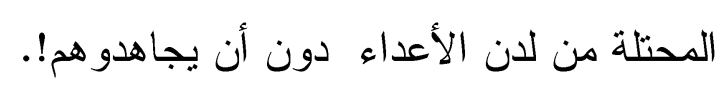

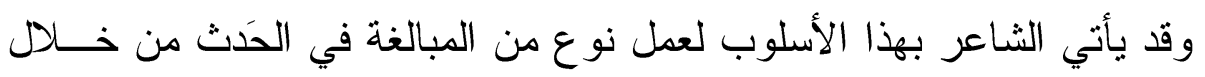
تكر اره غير مرة ليعكس فداحة المعاناة، كقوله:

$$
\begin{aligned}
& \text { بعد شهر } \\
& \text { لم نعد نخرج للشار ع ليلاً } \\
& \text { لم نعد نحمل ظلاً }
\end{aligned}
$$

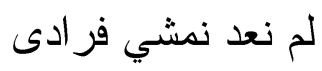

$$
\begin{aligned}
& \text { لم نعد نملك ز ادا } \\
& \text { لم نعد نفر ح بالضيف } \\
& \text { إذا ما دقّ عند الفجر باب } \\
& \text { لم يعد للفجر باب! (178) }
\end{aligned}
$$

فأحدث الثاعر من خلا أسلوب النفي الذي كرره غير مرَّة نوعًا من المبالغة

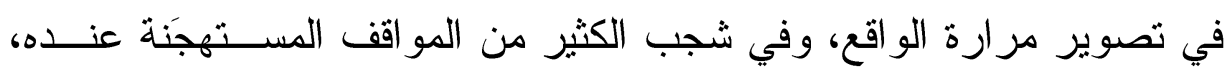

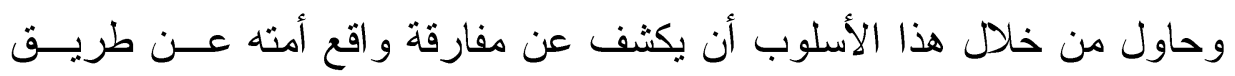
إثبات الثيء ونفيه ليخالف التَّقفع لدى المتلقي.

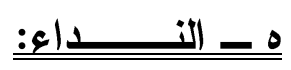

ثمة رسالة مُوجَّهَة من الثـاعر إلى شعبه العر اقيّ خصوصـًا ولشعوب الأمـــة

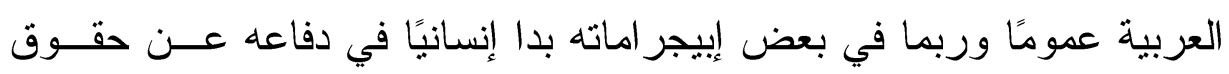
الإنسان و الشعوب ـ أيًا كانت جنسياتهر ـ في العدالة و الحريات، وحتى للفئات 
المجتمعية كانت هناك رسائل تدور حول الإطار نفسه، ومن ثم سيكون للنــــاء

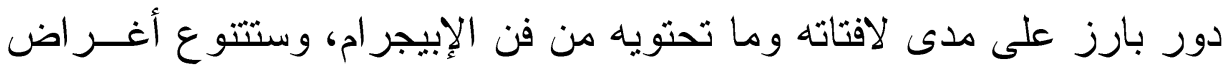

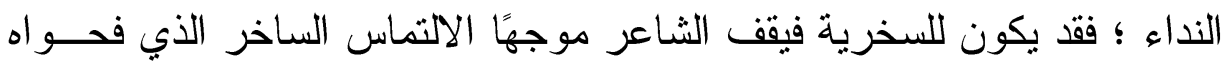
الدعاء على الحُكام بالهلاك مثلاً، يقول: أيها الحُكام بالله عليكم

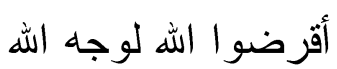
قرضًا حسنًا

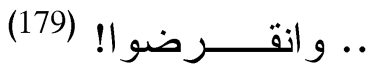
وقد يكون الغرض من النداء في الإبيجر ام الاستغاثة، فالشاعر يطلب المــدد

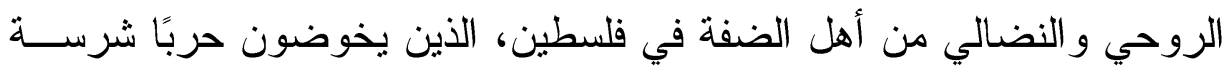

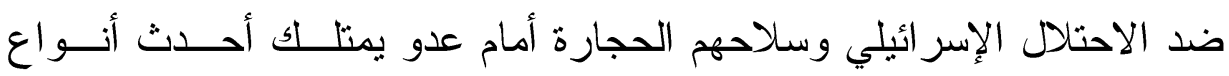

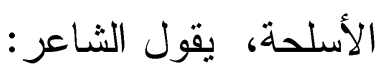

$$
\begin{aligned}
& \text { يا أبناء الضفة يا أحرار } \\
& \text { يا أهل الجنة } \\
& \text { إنا في النار } \\
& \text { نحن شعوب ديكور ات } \\
& \text { أعطونا صورنتا الأولى } \\
& \text { و أعيدونا } \\
& \text { من منفى هذه الأوطان } \\
& \text { و إذ أنتم } \\
& \text { حجر يكسر نافذة النسيان } \\
& \text { ليذكرنا }
\end{aligned}
$$




$$
\text { وذكَرَنا صورتنا الأولى }
$$

ونجد الشـاعر في مواضع كثيرة يقوم بتجريد كثير مــن الرمــوز و المعـــي

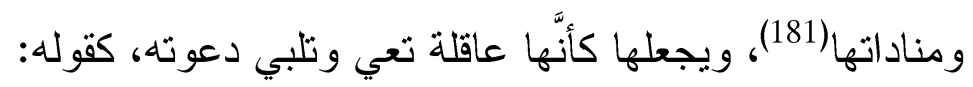

با قدس يا سيدتي.. معذرة

$$
\begin{aligned}
& \text { فليس لي يدان } \\
& \text { وليس لي أسلحة } \\
& \text { وليس لي مبدان } \\
& \text { كل الذي أملكه لسان } \\
& \text { و النطق با سيدتي أسعاره باهظةٌ } \\
& \text { و الموت بالمجان (182) }
\end{aligned}
$$

يرثى الثـاعر القضية العربية التي باتت أزلية ــ عنده وعنــد غيـره مــن

الشعر اء ـ و هي قضية القدس العربية و احتلالها من لدن إسرائيل وينعي تخاذل

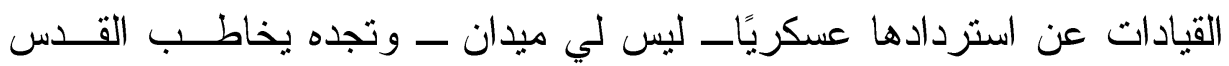

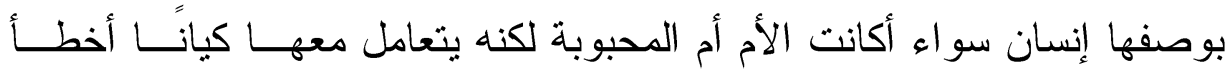
الجميع بحقه، ويُوجب الشاعر على نفسه الاعتذار لها على الرّغم أنه لم يقصِّر ـ على حد تعبيره - فقد وهب شعره للأمة على الرّغم من أنه سيكلفه حياته، وبحديثه عن القدس تجده أضفى عليها خو اص العقلاء،وناداها و اعتــذر إلبهـــا كأنَّا تعي ما يقوله. من خلال هذا الأسلوب وجه الشاعر الدعوة إلى الشعوب لاقتشــام أحــلام الحرية و العدل ورفض و اقعهم الخلو منهماكوتعددث فئات المنادى سواءً أكــان

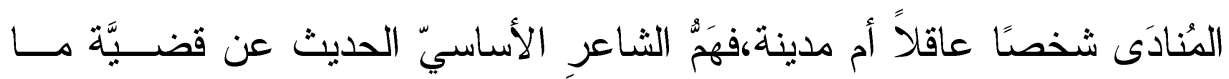
وجعل المتلقي يتهاعل معهاهويفكر في حلها. 


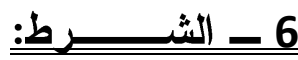

أحد أساليب صياغة الجملة قوامه هو جملتان" كثيرًا ما تكون الأولى ســبًا

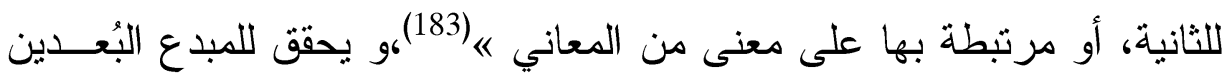

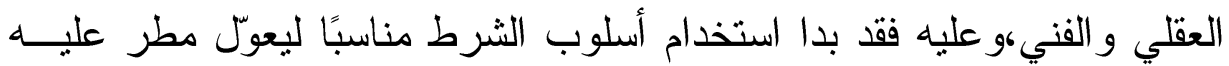

في لافتاته، يقول مستخدمًا الأداة(لو):

ومقالتي: أنا لن أنافق

حتى ولو وضعو ا بكفيَّ

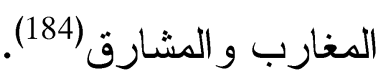

وقد ترد عنده على معناها الاصـــلاحي،وهو ا(امتتــاع الثـــيء لامتتـــاع

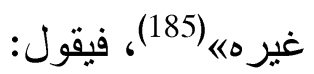

آه لو لم يحفظ اله كتابه

لتولته الرقابة

ومحت كل كلام

بُغضب الو الي الرجيز

و لأمسى مجمل الذكر الحكيم

خمس كلمات

كما يسمح قانون الكتابة

$$
\text { "قي: }
$$

.... صدق الله العظيم"! (186)

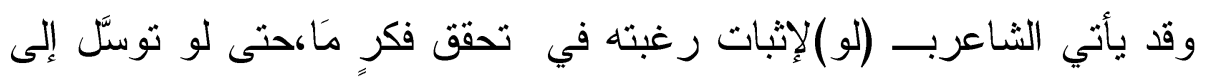

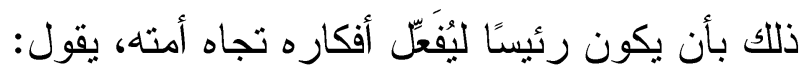

$$
\text { أنا لو كنت رئيسًا عربيًا }
$$

لحلت المشكلة 


$$
\begin{aligned}
& \text { وأرحت الشعب مما أثقله } \\
& \text { أنا لو كنت رئيسًا } \\
& \text { لاعوت الرؤساء } \\
& \text { و لألقبت خطابًا موجزًا } \\
& \text { عمّا بعاني شعبنا منه } \\
& \text { وعن سر العناء } \\
& \text { ولقاطعت جميع الأسئله(187) }
\end{aligned}
$$

7

أحد الأساليب الحاضرة بقوة في الشعر؛ لما له من تأثنر، ومع هذالالم يظفر بتسمية اصطلاحية في البلاغة العربيةه(188)،يتخلص الشاعر بواســـته مــن بعض قيود اللغة المألوفة(189)،و عن طريقه قد 》 تــتم عمليــة التو اصــل فــي مستو اها العادي المألوفه(190)، \سو اء كان الأمر يتعلق بالمنظور البلاغــي أو النحوي فإن ثزتيب الكلمات هو المظهر الرئيسي للتركيب وما ينجم عنه من مسائل التقديم و التأخير (191)، وقد يُحسب الانزياح عن هذه التراتب مروقًا عن الوظيفة النفعية للغة إلى الوظيفة الشعريَّة، وبسبب أهميته فقد كان موضـــوعًا

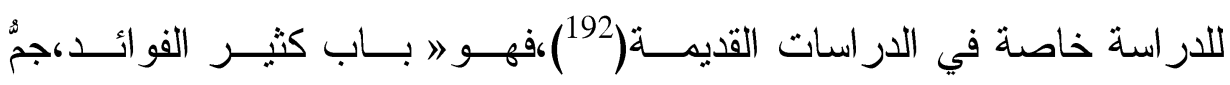
المحاسن،و اسع التصرف، بعيد الغاية) (193). وقد يلجأ البعض إلبه رغبةً في تسليط الضوء أو التأكيد علـى أمسـر بعينـــهـ

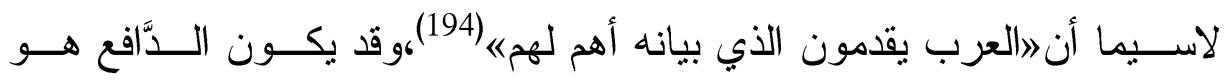
ترتيب عناصر الجملة، وإخضاعها لنظام موسيقي مُحكَم.وللتقديم صور عديدة.

و عن فن الإبيجر ام فقد احتفى بأسلوب التقديم و التأخير في أثـــاله المتباينــة لتحريك الدلالة و التأكيد عليها؛ خاصة أنها شديدة التَّثثيف لتمنح المنلقي مجــالاً 
من الرؤى و الدلالات، يقول في إبيجر ام قد ينقسم إلى إبيجر امين فــي الوقـــ ذاته:

$$
\text { [ قلمي وسط دواة الحبر غاص غاصر }
$$

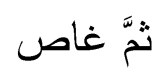

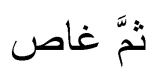

قلمي في لجَّة الحبر اختتق

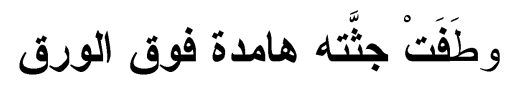

روحه في زبد الأحرف ضاعت في المدى)(1)

$$
\text { (آلاص (ل) }
$$

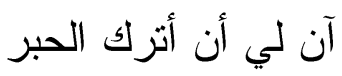

وأن أكتب شعري بالرصاص!)(2)] (196).

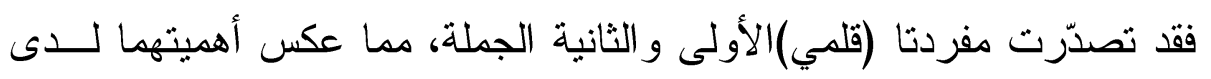

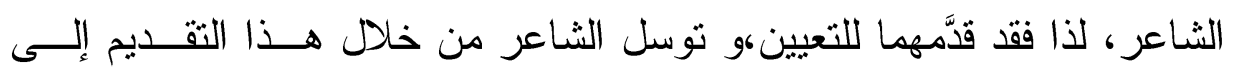
توضيح قناعته الخاصة؛و هي أنَّ هذه الأداة ليست كافية وحدها لتَجلب الحرية وتُشط الطغاة، بل إنها بحاجة إلى القوة لتحقيق الأحلام.

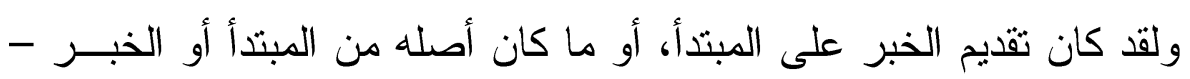

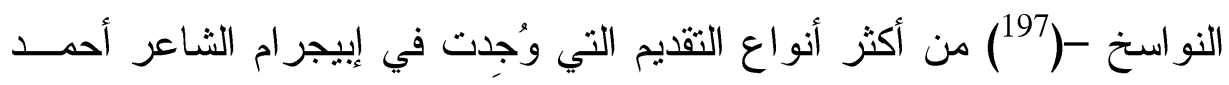

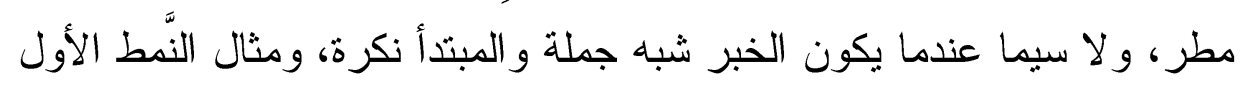
قوله: مطر،

$$
\begin{aligned}
& \text { فحيث سرت 'مخبر" } \\
& \text { يلقي عليّ ظله } \\
& \text { يسبح في محبرتي لي لي لئي } \\
& \text { يطلع لي في الحلم كل ليله؛(198) }
\end{aligned}
$$




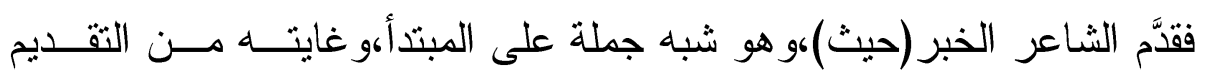

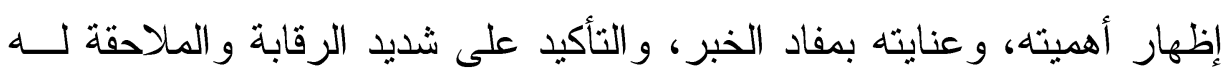

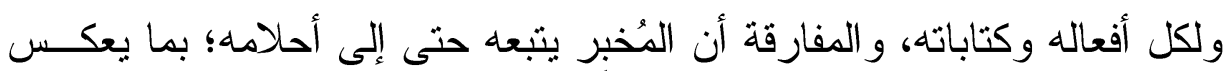

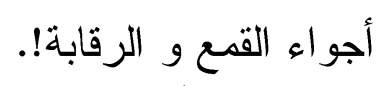
ومثال النَّمط الثاني ما نجده في الإبيجر ام الآتي؛ حيث قدَّم الثاعر خبــري

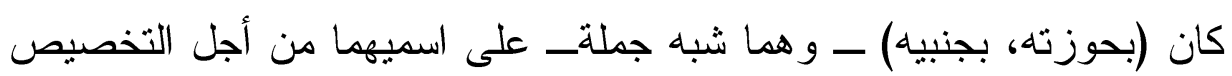
تخصيص القتل بكل شخص شريف، وبكل شخص يمنالك ضميرًا حيًا، ويُعلــي وني

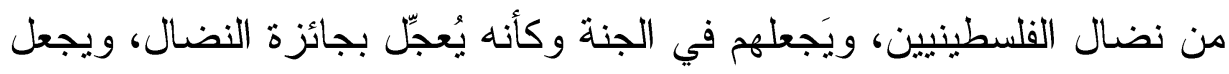

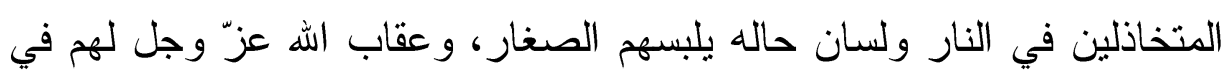
الآخرة على تقاعسهم في نصرة الأرض المُحتلَّة، ويقول:

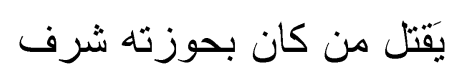

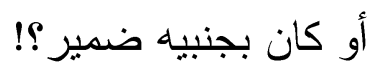

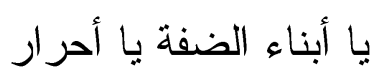

$$
\text { إنّا في أهل الجنة النار (199) }
$$

ومن أمتلة تقدم الجار و المجرور على الفعل و الفاعل و المفعول به مـــا ورد في الإبيجر ام الآتي؛ ويؤكد من خلاله فكرة امتهان كرامة الموان اطن العن العربي في

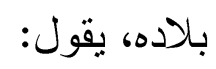
في مقلب القمامه رأيت جثة لها ملامح الأعراب.... تقول: هذه جيفه

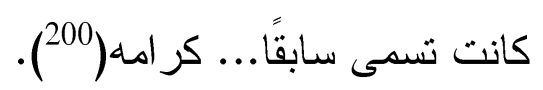

وقد يأتي بشِيه الجملة في مقدمة الجملة للتخصيص منل ما فعل في الإبيجرام التالي؛ حيث أراد أن يبرز المفارقة لدرجة المبالغة بين حقوق المواطن في بلاد 
الغرب/المشركين - على حد تعبيره ـ وبلاد العرب/ اليمـين ـ علــى حـــ تعبيره أيضًا ــ وقد وُفِّق الشاعر في تقديم الجار و المجرور في مفتتح الإبيجرام فجذب المتلقي لرسالة المفارقة، يقول: في بلاد المشركين يبصق المرء بوجه الحاكمين فيجازى بالغر امة! ولدينا نحن أصحاب اليمين

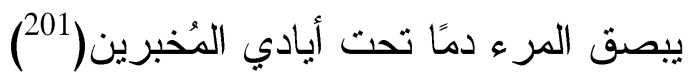
و أحيانًا يقصد إلى تقديم جو اب الشرط على فعله للهدف نفسه من إبراز الفكرة

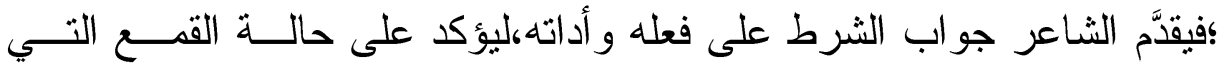
يلاقيها من الحكام المستبدين،وليشير إلى أجو اء الرقابة، فيقول:

$$
\begin{aligned}
& \text { بتر الو الي يدي ليّا رآني } \\
& \text { في كتاباتي أرسلت أغاني } \\
& \text { إلى كل مكان }
\end{aligned}
$$

وضع الو الي على رجلي قبدًا

$$
\text { بين كل الذ رآني }
$$$$
\text { دون كفي ولساني }
$$$$
\text { صامتًا أشكو هو اني (202) مكاني }
$$

و هكذا بدا أسلوب التقديم و التأخير موظفَّا لدى الثـــاعر لينــأى بإبيجر اماتــهـ

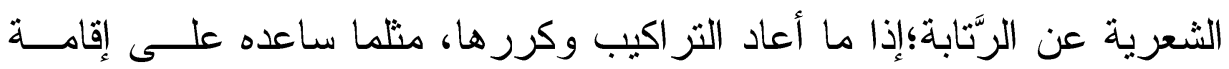

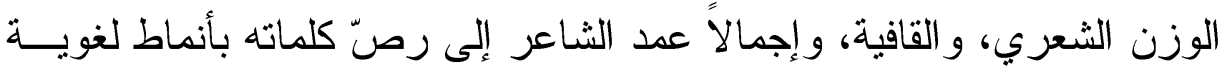
متعددة، بما أتاح للغته الشعرية أن تغدو ثرَّة في سياقاتها،ومؤثرة في دلالاتها. 


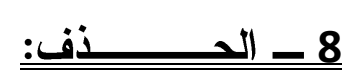

الحذف أحد فصول الفصاحة و البلاغة(203)، قال الجرجاني اإنَّك ترى تــرك

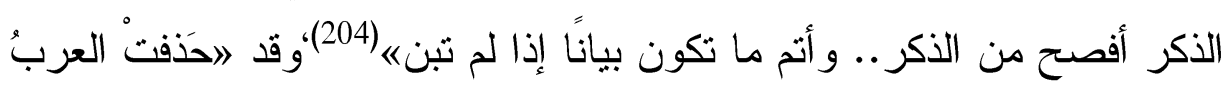

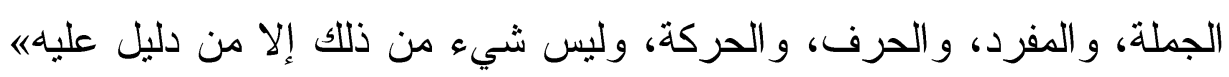

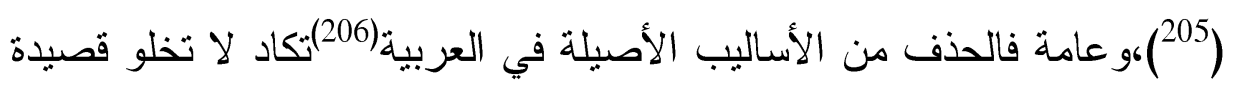

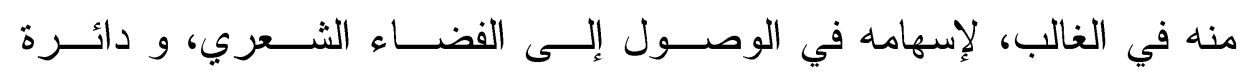

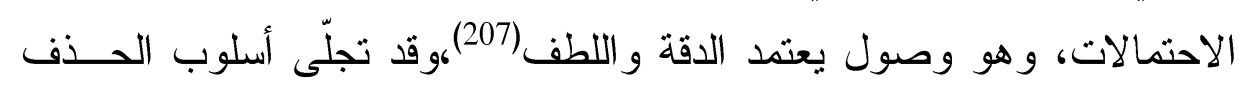

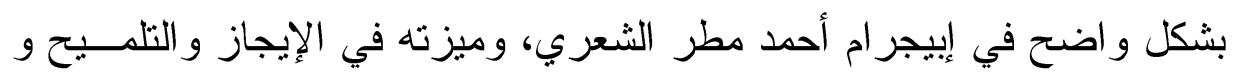

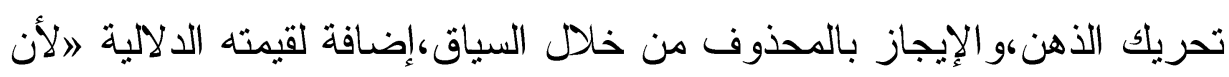

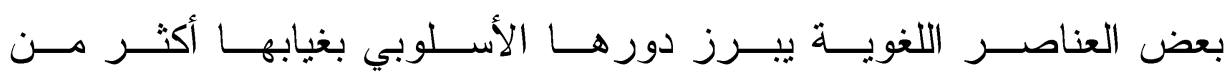
حضور ها《(208)،ومن صور الحذف لديه قوله:

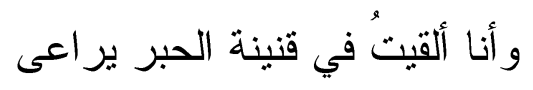
وتناولت التياعي فوق صحن الورقة شاعر السلطة حلى بالنياشين ... وحليت بحبل المشنقة! (209)

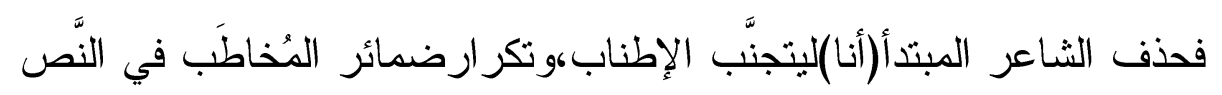
غير مرَّة. وكذا يلجأ إلى حذف المبتدأ المسند إليه وتقديره(هذه) في إبيجر امــه الآتـي

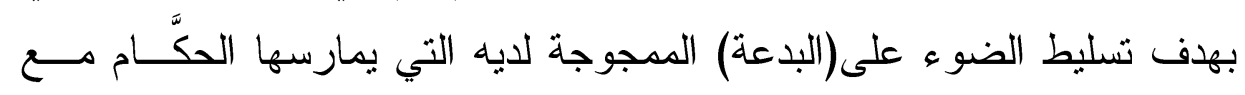

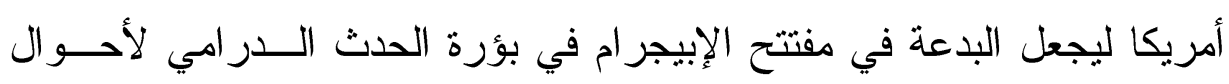
أمته، فقادة أمته لا يملكون سوى الثجب و التتديد، وعن أمريكا فهي إمّا ساكنة

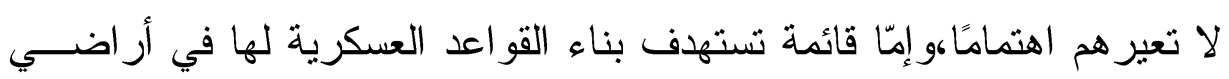


العرب!، وفي هذا قمة المفارقة بين العرب الذين لا يملكــون سـوى الكــلام

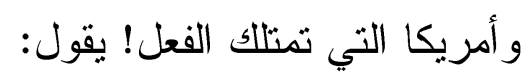
بدعهُ عند و لاة الأمر كلهم يشتم أمريكا

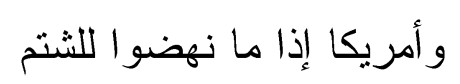
تبقى قاعده:

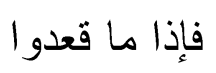
تتهض أمريكا لتبني

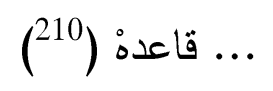

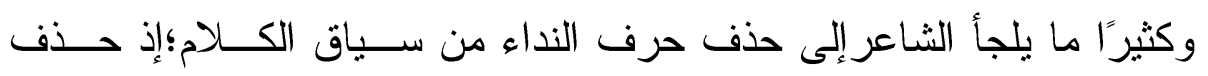
الثاعر حرف النداء(يا)،و التقدير (يا ربّي) لدلالة السياق عليه،و لأنه يؤطر الكلام

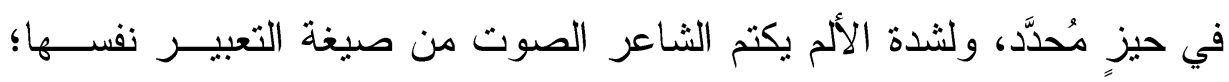

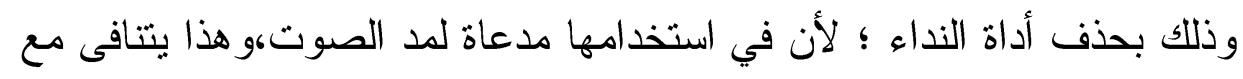
زمن الكتمان و الرَّهب الذي أراد أن يعبر عنه معنى ومبنى، يقول:

$$
\begin{aligned}
& \text { ربّّ إنَّ الصوت موت } \\
& \text { ربِّّ إنَّ الصمت موت إن } \\
& \text { كيف أحيا في بلاد } \\
& \text { تكتم الصوت بإطلاقة إسكاتٍ } \\
& \text { وحتى كاتم الصوت بها } \\
& \text { في فمه... "كاتم صوت"! (211) }
\end{aligned}
$$

و قد يحذف الثاعر جملة جو اب الثرط في بعض نصوص إبيجر اماته مــن

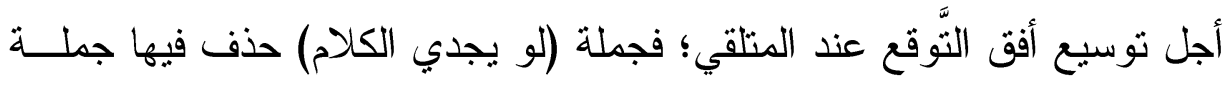


جواب الشرط من جانب،ويكررها من جانب آخر،وكأنه بطهح أن يوجد مَـنـ

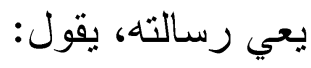

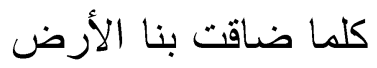
أفادونا بتوسيع الكلام

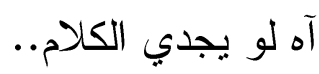

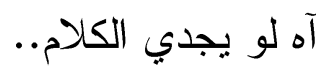

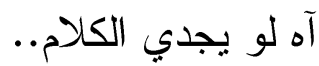

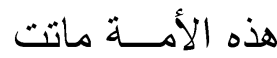

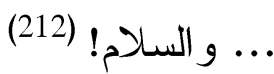

وأحيانا قد يستغنى الثاعر أحمد مطر عن الجملة بأكملها ما دلَّ عليها السياق،

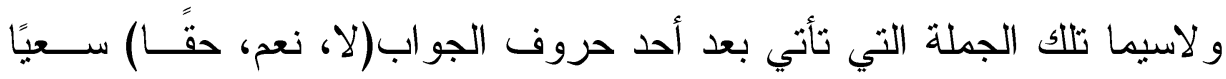

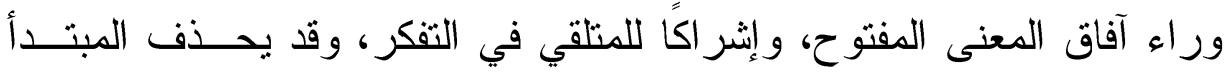

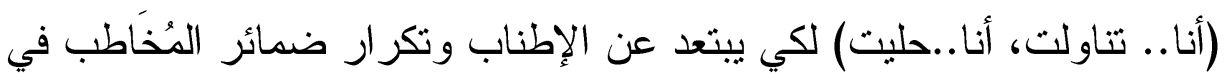

$$
\begin{aligned}
& \text { النص، يقول: } \\
& \text { أغباء أم غرور } \\
& \text { أم حنين للجذور اغبء } \\
& \text {... }
\end{aligned}
$$

بل الحرية العذبة تجري في دماها

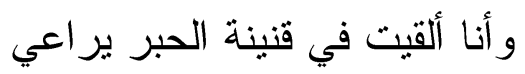

$$
\text { وتتاولت النياعي }
$$$$
\text { فوق صحن الورقهُ }
$$

شاعر السلطة حلى بالنياشين

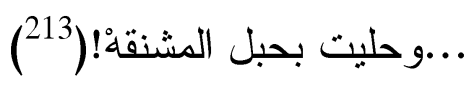


ومن أنماط الحذف في إيبجر امات أحمد مطر؛ حذف بعض الحــروف مــن الكلمة، أو حذف الكلمة، أو حذف الجملة، ويضع مكان ذلك بعض النقاط للالالة

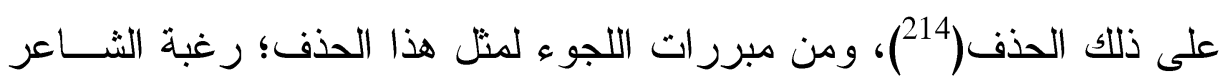
عن ذكر بعض الكلمات البذيئة؛ حيث يقول:

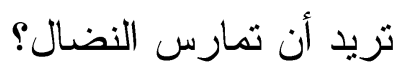
تعال اجمع شعار ات جميع الأنظمة و امسح بها... وبُلْ على كل ثقارير مصير الأمم المتهمة! و ابصق بوجه قادة الجريمة المنظمة ذوي الكروش المتخمة من دمنا المسال(215)

وقد يرغب من خلا أسلوب الحذف في إحداث دلالة على الفجوة الزمنية بين الأحداث التي تقع ؛ حيث ״إن الفراغ (بياض البيت الشعري) يفعل فعله هنا

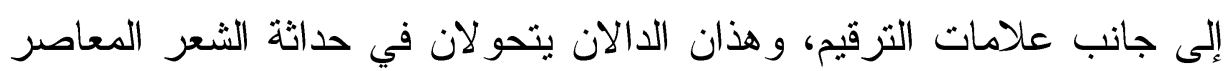

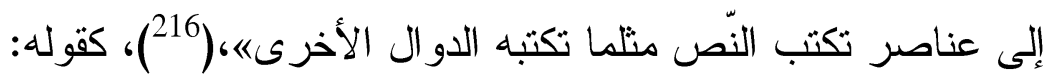

$$
\begin{aligned}
& \text { أيّها الموت... عزيزي } \\
& \text { للك شكري } \\
& \text { انتظر } \\
& \text { أنني سأدعوك إليَّ } \\
& \text { قسمًا إني سأدعوك إليَّ سنّادي } \\
& \text { عندما أشعر يومًا } \\
& \text { إنني يا موت... حي!) }
\end{aligned}
$$


ففي هذا الإبيجز ام؛ مابين الفعل انتظر وما بعده من بياض في السطر و الفعل

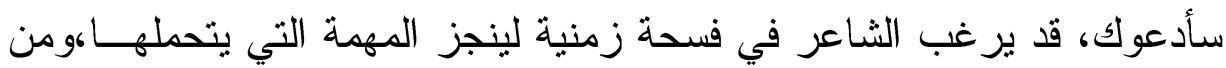

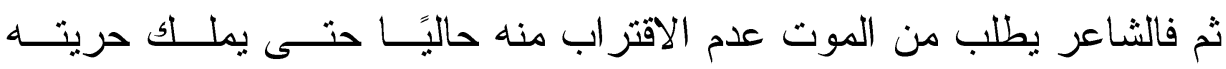
المفقودة، و عند ذلك يستطيع دعوة الموت.

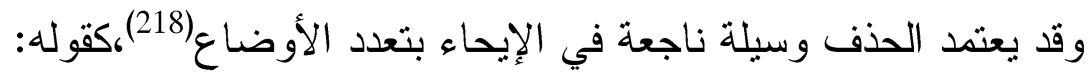
أنا......

حرب دائره ثورة شعبية في القاهره عبوة ناسفه

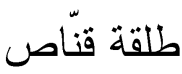
كمين طعنة في الظهر ثأر هزة أرضية في أنقره أنا........ si...... تلك الـ........... أ.... كرة الملاك اهتز مذهو لاً و ألقى دفتره(219).

في هذا الإبيجر ام يجسد أحمد مطر مأساة الإنسان في الأرض،ويشـير إلــى

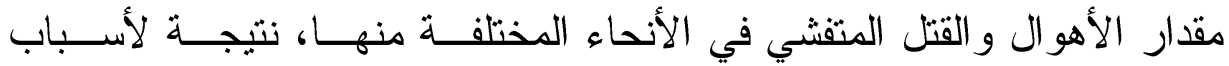
متتوعة؛ منها ما هو من فعل الطبيعة ومنها ما هو من صنع الإنسان.

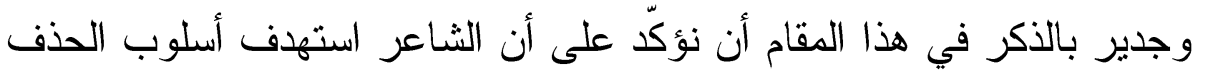

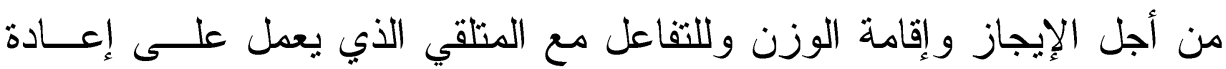




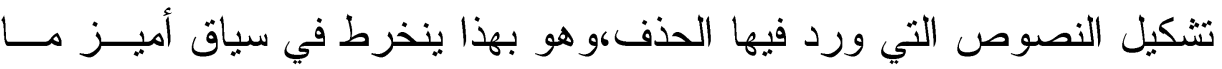
يميز فن الإبيجر ام الشعري من التكثيف والإيحاء و الإشارة.

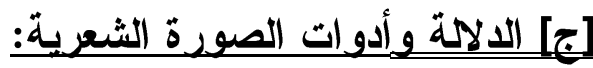

الدلالة(220)تثبدى من خلال تَشَابَّك المفردة مع المفردات الأخرى فيتحقق البُعد

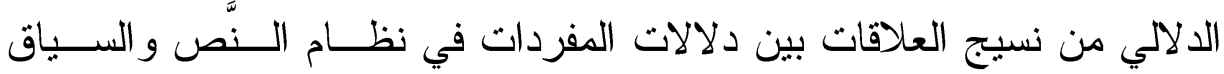

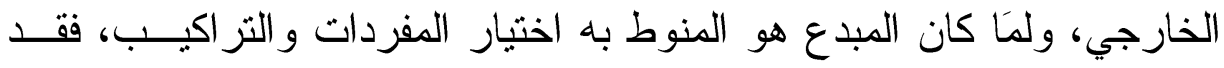
يمكن قياس مقدار إبداعه الفني عن طريق النظر إلى الأبعاد الجديدة التي توسّل إليها بذلك الاختيار و التركيب. (221) وقد يكون الخروج باللفظ من الحقيقة إلى المجاز هو أحد البدائل المتاحة التي

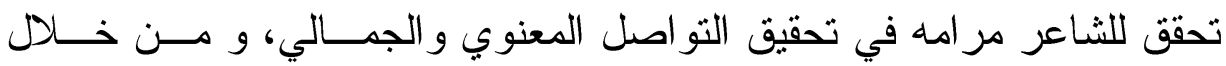
الصورة الثعرية التي يخلقها المبدع من استعمال ؛التشبيه والاستعارة و الكناية

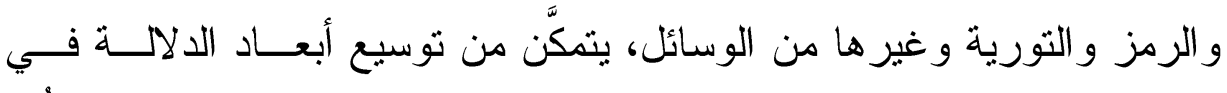

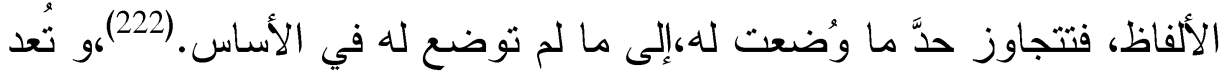

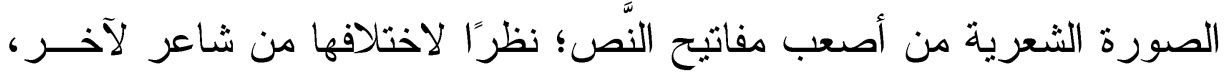

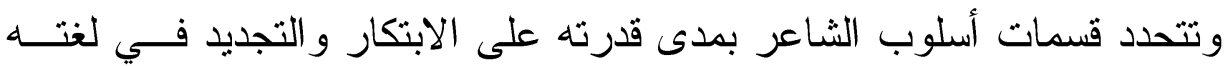
الشعرية؛(فالصورة هي وسيلة الشاعر للتجديد الشعري و التّرده( (223)،

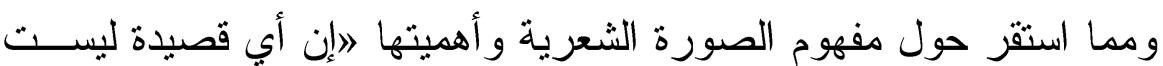
مجرد صور، إنها على أحسن الفروض صور في سباق..لها علاقـــة بســائر مكونات القصبدة)( (224). و الصورة الشعرية كانت حاضرة بقوة في قصيدة الإبيجـــر ام؛ لأن قــــوام

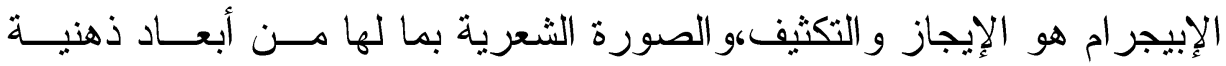

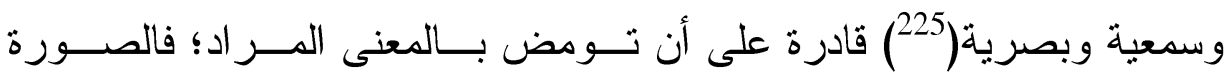
الشعرية تتمتع بطاقات تعبيرية تفوق غير ها من صور الفنون المختلفة(226). 
وسيتتاول هذا المبحث من هذه الدراسة أبرز الأدوات التي توسل الثــاعر

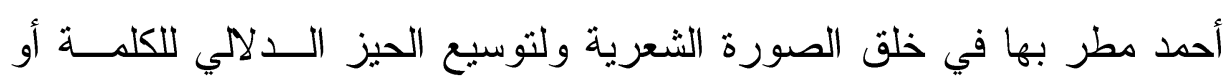
العبارة، داخل سياق الإبيجر ام الشعري، ومن هذه الأدوات (التشبيه،الاســتعارة

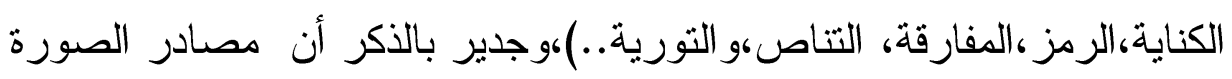

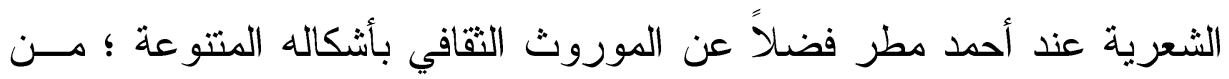

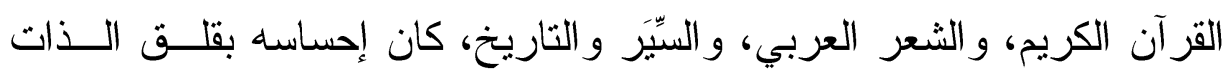

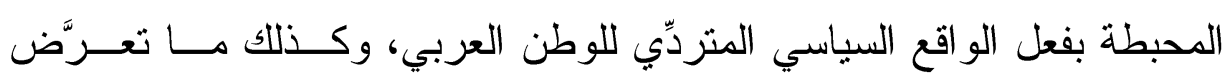

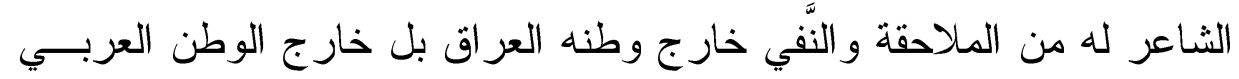

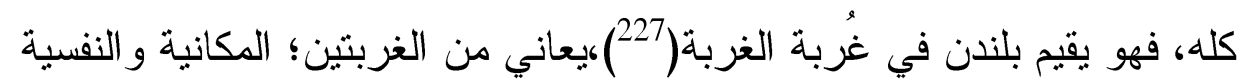

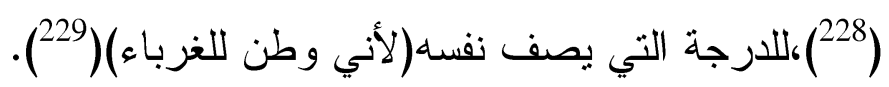

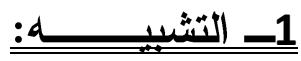

التشبيه وسيلة رئيسة في بناء الصورة الشعرية، وأساس لكثير مــن الألـــوان

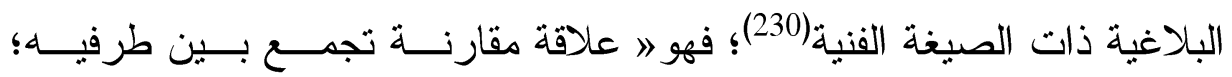

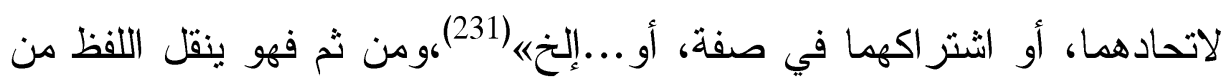

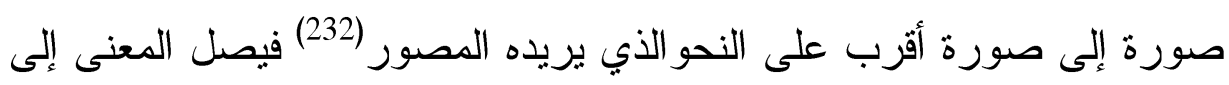

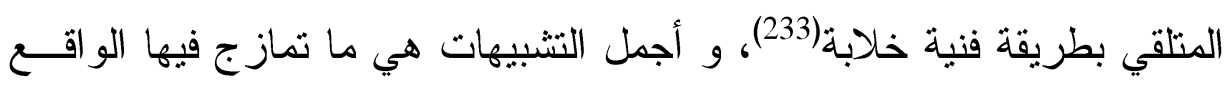

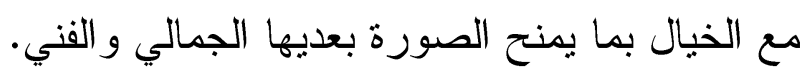

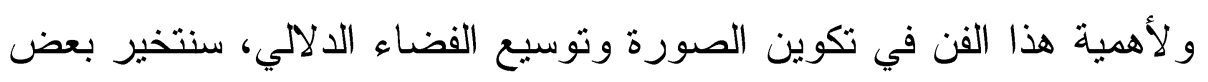

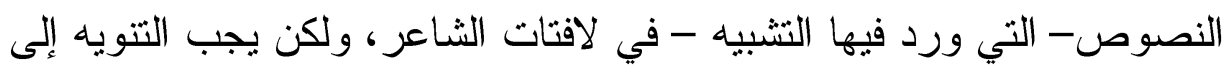

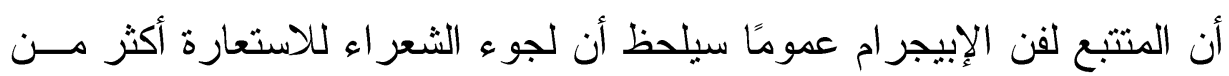

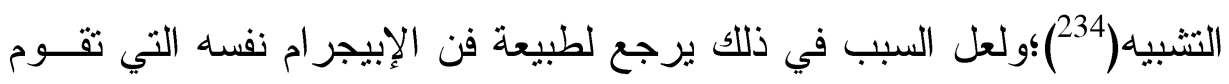

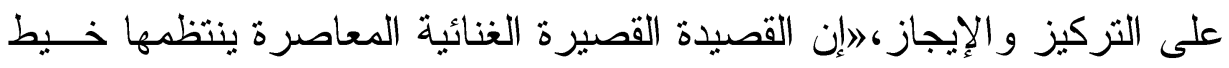

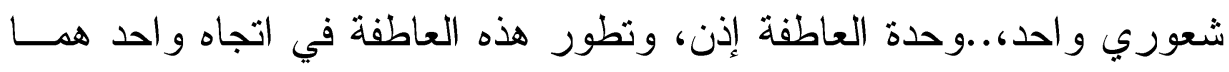

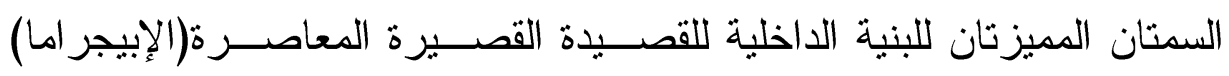


الثعريةها (235) ومن ثم فسوف تسعف الاستعارة الثشاعر فــي القـبض على

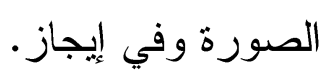

و أول الأسباب التي دفعت الثاعر إلى توظيف التشبيه محاولته إعطاء صورة عن نفسه و اضحة أمام متلقيه، و التشبيه يسعف كثيرًا،يقول:

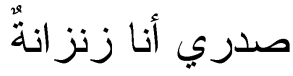

$$
\text { قضبانها ضلوعي }
$$

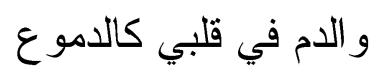

$$
\text { يلومني }
$$

لأنني مبذر في نعمة الخضوع! (236).

فالثاعر لجأ للتشبيه البليغ أو المؤكد الذي حُذفت أداته في الجزء الأول؛ فثبّه صدره بـــ (زنز انة)،وكذا ضلو عه بــ(القضبان)، وفي الجزء الثناني؛ حيث شبَّهَ

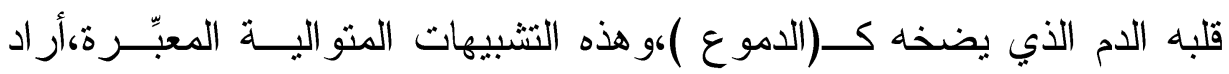
الشاعر من خلالها أن يؤكد معاناته حيال وطنه،ويأمل في تحرره.

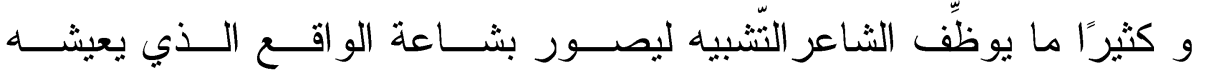

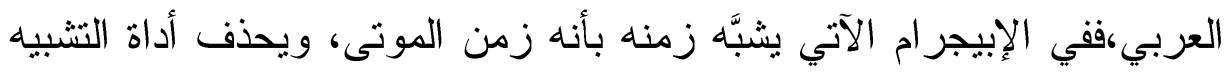

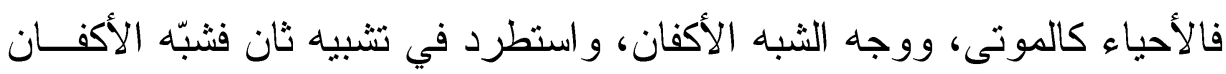

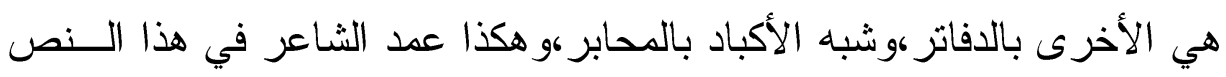

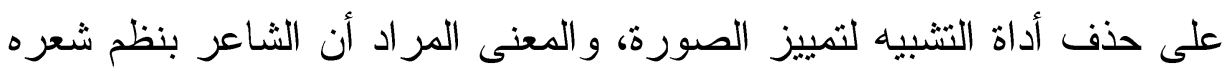

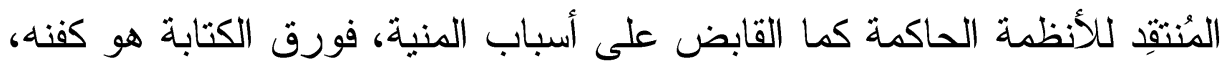

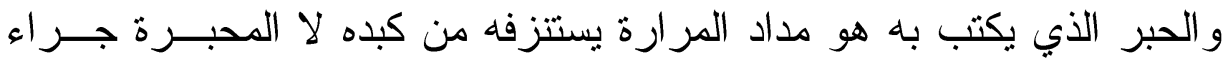

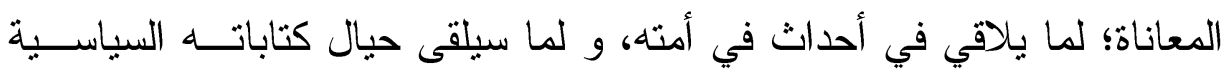

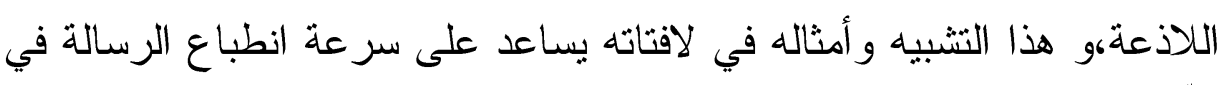

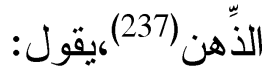




$$
\begin{aligned}
& \text { في زمن الأحياء الموتى } \\
& \text { تتقلب الأكفان دفاتر } \\
& \text { و الأكباد محابر } \\
& \text { و الشعر يسد الأبوابَ } \\
& \text { فلا شعر اء سوى الثهداء (238) }
\end{aligned}
$$

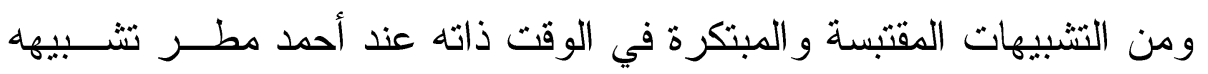

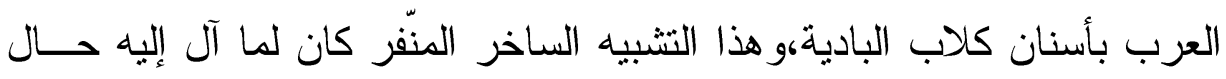

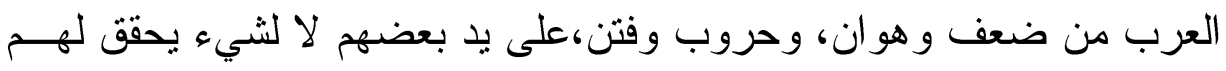

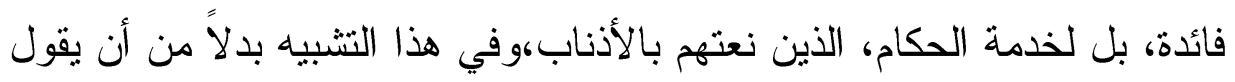

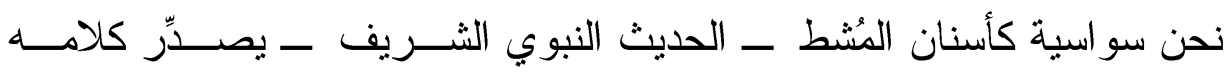
بصدمة قمة في التهكم! وذلك في تشبيهه الساخر المكتمل الأركان ؛ من ذكـــر

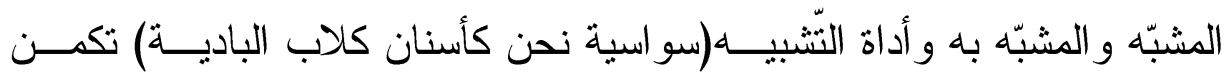

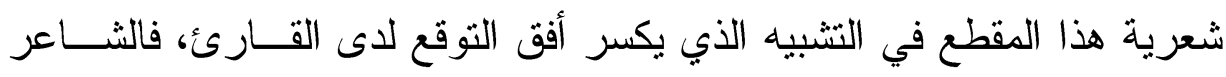

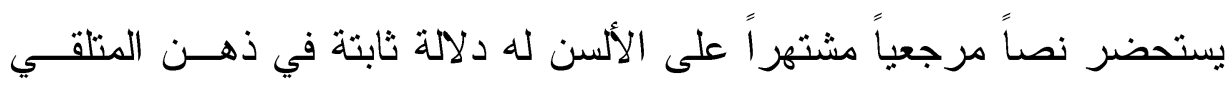

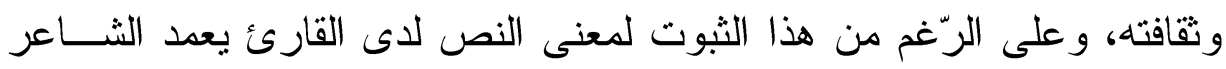

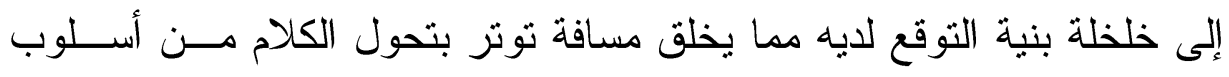

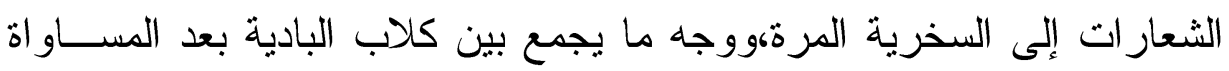

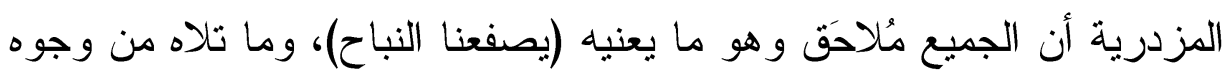

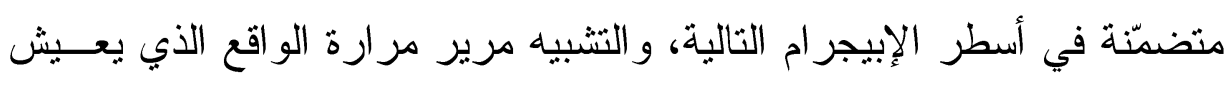

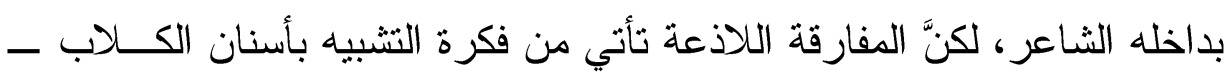

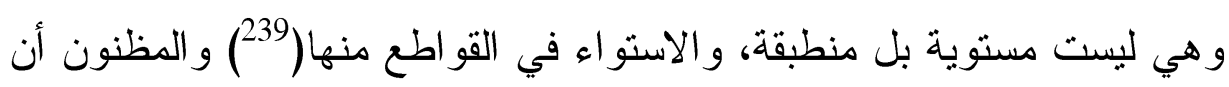
الثاعر أراد الإمعان في الازدر اءهوكا المفارقة في المقطع الأخير عندما يقول

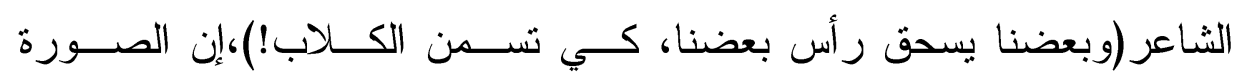




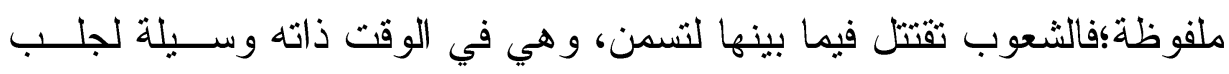

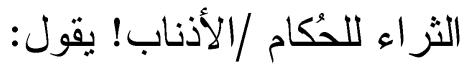
سو اسية نحن كأسنان كلاب البادية يصفعنا النباح في الذّهاب و الإياب يصفعنا التراب رؤوسنا في كل حرب بادية و الزهو للأذناب

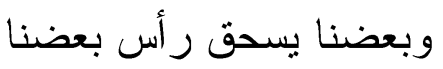

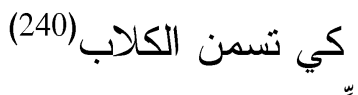
وِّيندد الثاعر في إبيجر امه الآتي باستكانة الشعوب، ويشبهـا ــ وهي عاجزة

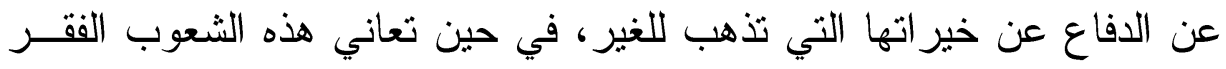

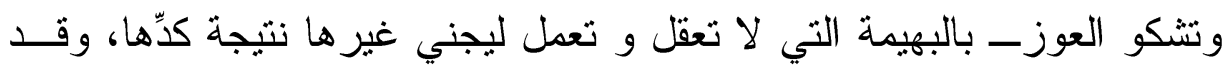

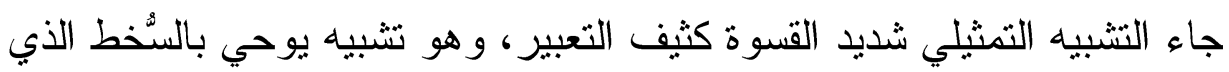
سيطر على الشاعر السياسي المنفي عن وطنه(العراق)، ثم يشير إلى الذل الذي

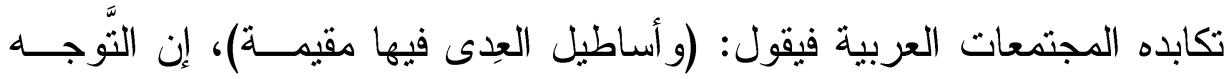

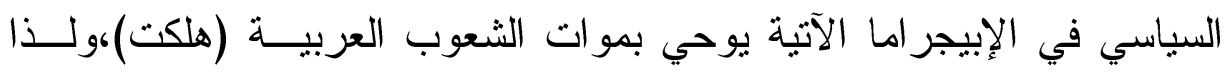

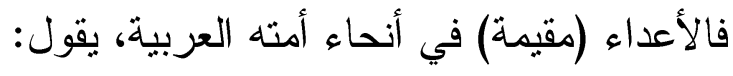

$$
\text { "أي قيمة }
$$

للشعوب المستقيمة

وسجاياها الكريمة

في بلاد هلكت

من طول ما دارت على آبار ها 


\section{مثل البهيمة و استقلت \\ و ؤساطيل العدى فيها مقيمة ؟!". (241)}

و الخلاصة أنه تجلّت مساحة من التشبيه في قصيدة الإبيجر اما إلى حدِّ ما لكن

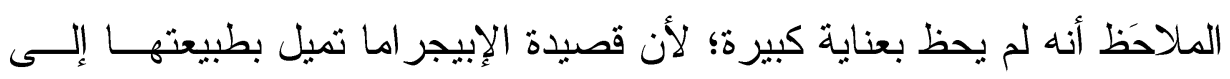

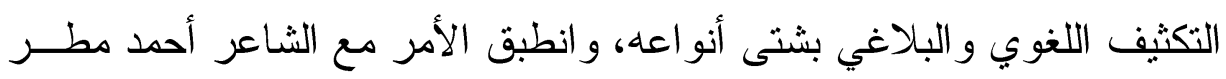

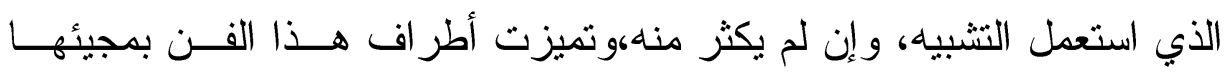
مجسَّة لا مجردة - في الأكثر - ولعل سبب ذلك، رغبة الشاعر في الاستحو اذ على أكبر قدر من التأثير في المتلقي وجذبه الآلى إبيجر امه. 2 2

جوهر إبداعي رئيس وداعم للصورة الثعرية، وتمنح القارئ مِيـــة مــن

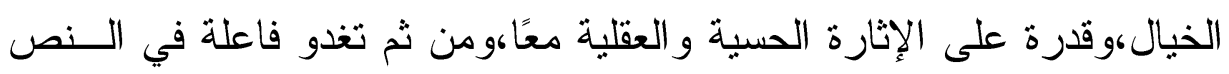

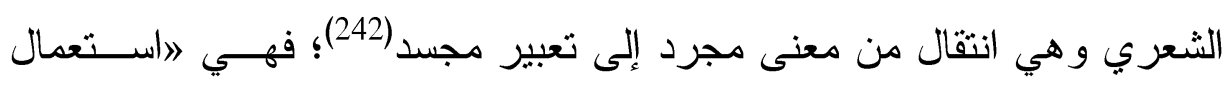

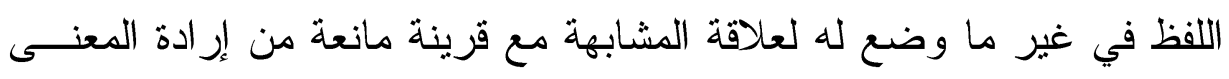

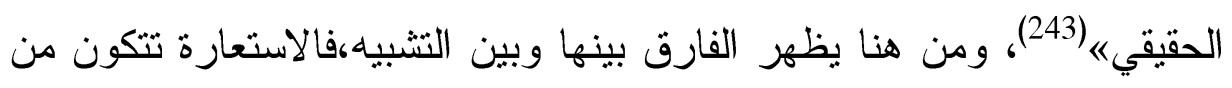

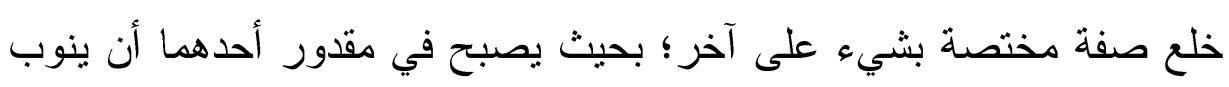

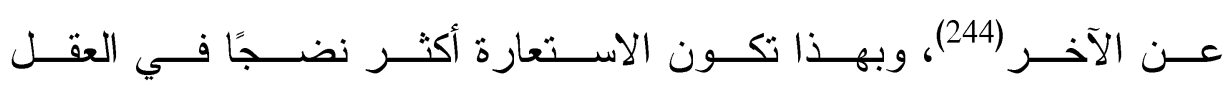

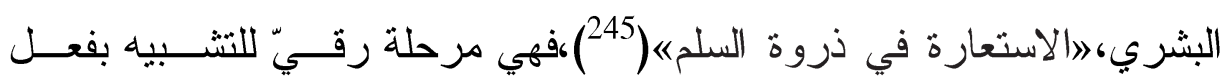
الحضارة وارتقاء الفكر الإنساني(246).

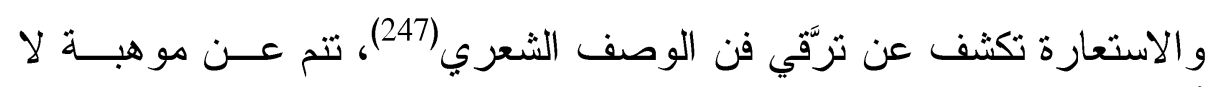

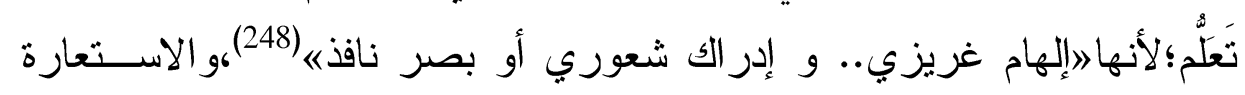

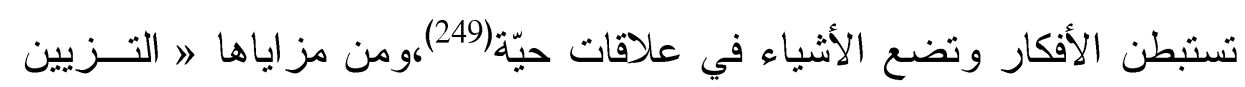
و التجميل و الاختصار و الإيجاز 《(250). 
ولمّا كان الإيجاز من خصائص الاستعارة، ولمّا كانت السِّة المميـزة

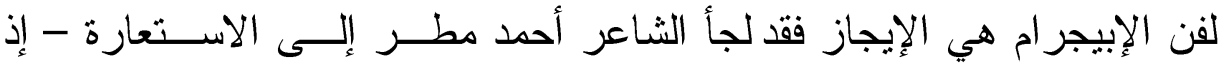

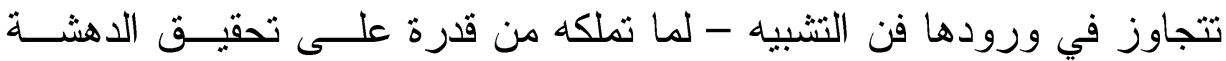
و التأثير الذي يدوم؛و لما لها من توسيع دلالة العبارة،و من استعار اته الطيبة ما ها ورد في هذا الإبيجر ام التالي، يقول: (251) يخفق" الرَّقاص" صبحًا ومساء. ويظن البسطاء أنَّه يرقص! لا يا هؤ لاء. هو مشنوق

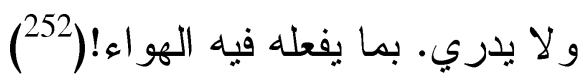

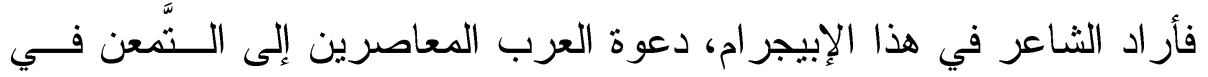

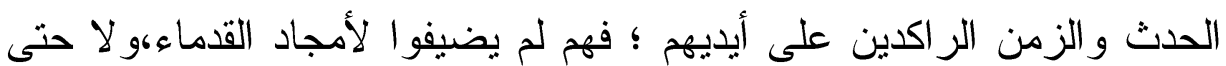

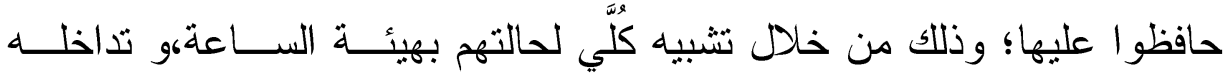

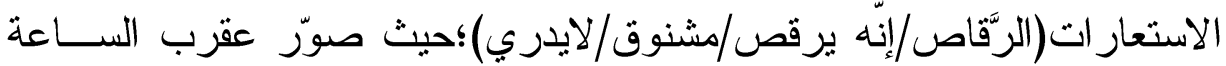
بالإنسان المشنوق و المقيد من رقبته، ويفتقد للتمييز و الإدر الك، وهو يلف بانتظام

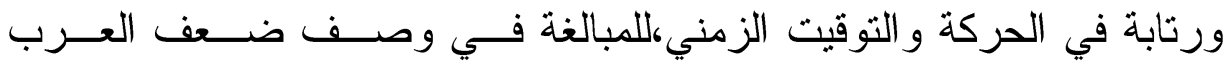
و استسلامهم وفقده لتقدير الزمن وعجزهم هن الإتيان بفعل يرفع عنهم المذلّة

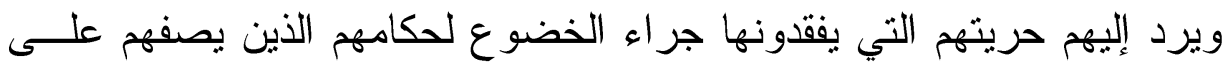
سبيل المفارقة من أن العرب يسنسلمون لحكام مناهم مثل الهو اء!. ويكثر الثشاعر من الاستعارة التي يضفي فيها من صفات الكائن الحي علــى

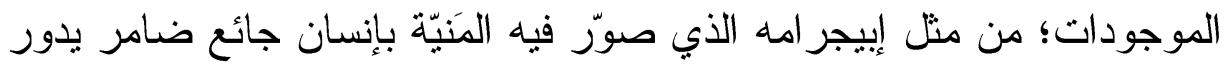
في البلاد بحثًا عن روح و عن دم عربي لكن لا تجد فتضجّ وتخرج في مظاهرة 


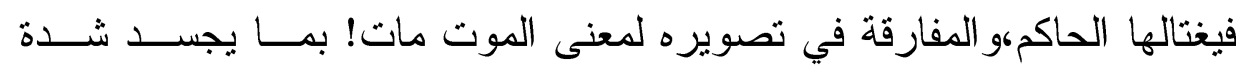
المعاناة، يقول: إن المنايا في بلادي دائره جائعة وضامره تبحث عن كسرة روح عن دم، عن أدمع تبحث عن شعور عندما تفشل في العثور على حياة حيه تخرج في مظاهره فيأمر الحاكم باغتيالها

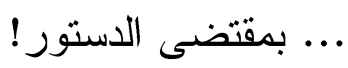

حتى الردى يقتل عندنا إذا حاول أن يثور !(253)

وفي إيبجر ام معبّر عن رفضه خضوع الحكام العرب للغرب وتبعيتهر - في

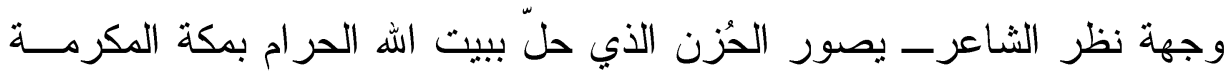
بعد دخول السعودية في علاقات مع أمريكا في العقدين الماضيين، وخلال هذا لهاب

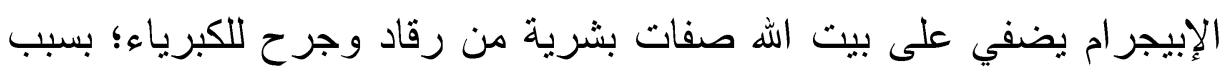

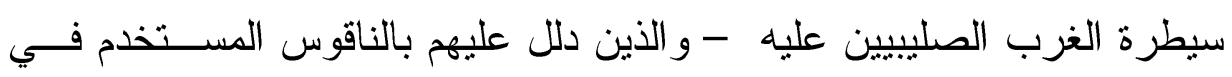
الكنيسة ومن لوازمها - وتَسلُّطهم علي المقيمين حوله، ويتصور أيضًا أن الحُلَّة السوداء التي تكسو جدرانه هي علامة على حالة الحداد على مَن قُتِل من أبناء

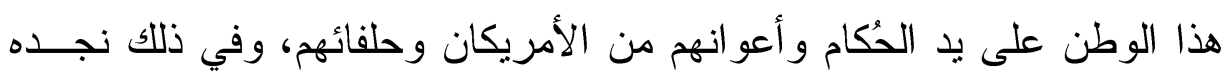




$$
\begin{aligned}
& \text { فوق آبار الشقاء } \\
& \text { لم يزل يرقد بيت الله } \\
& \text { محزونًا.... جريح الكبرياء ليرّاء } \\
& \text { لم يزل مرتديًا ثوب حداد } \\
& \text { لم تزل تغسله منّا دموع ودماء (254) } \\
& \text { ويقول في إبيجر اما تمثل الومضة معنىً وبناءً وتصويرًا: } \\
& \text { "حينما اقتيد أسيرًا كئس } \\
& \text { قفزت دمعته } \\
& \text { ضاحكةً: } \\
& \text { ها قد تحررث أخيرًا!". (255) }
\end{aligned}
$$

في الإبيجر ام السابق من خلال سمت السرد،وأسلوب السخرية في آن واحـــ يستخدم الثاعر الاستعارة التي تعتمد على تز اسل الحواس بشكل متميــز فـــي قوله: قفزت دمعته ضاحكة؛ فمن خلال مفردات ثلاث (قفزت،دمعة،ضاحكة) لا تلتقي في الو اقع؛ فأنى للادعة أن تكـــون ضـــاحكة ؟!، فالضــــك للشــفاه لا

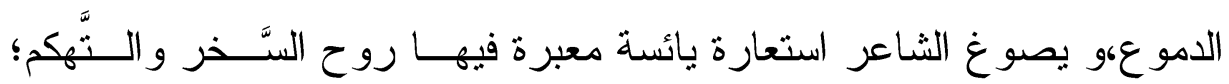

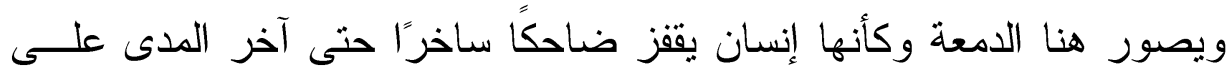
الرّغم من أنه أُقتيد أسيرًا ؛فيقول:ها قد تحررث أخيرًا! وتتجلى المفارقة القوية

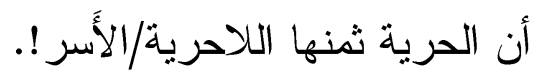

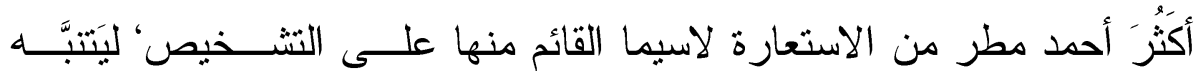

المتلقي و يبحث عن الدلالة وما وراء العبارة المطروحة عليه من خلال صورة غير مباشرة تتوسل بموجودات أضفى الثاعر عليها بعض صفات الأحياء.

$$
\text { 3 }
$$

الكناية أحد أدوات الصورة الشعرية التي من شأنها منح النصوص الثــعرية ثر اءً دلاليًا لما تحتويه من تكثيف للمعنى في طباتها،فهي لأن يريد المتكلم إثبات 


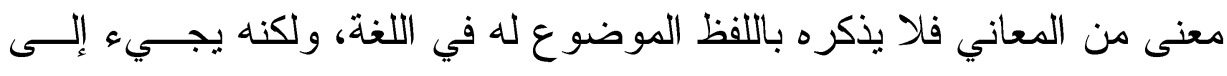

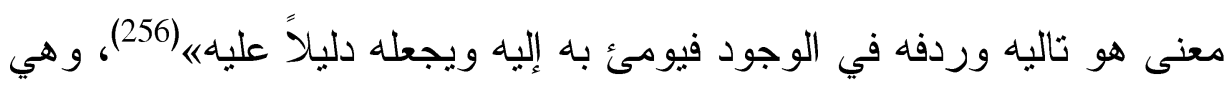

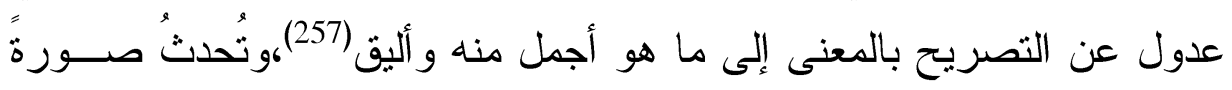

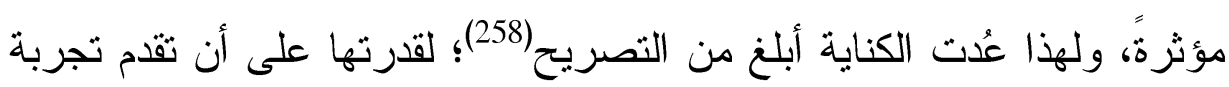
الثاعر في غير مباشرة، وبشكل مؤثر (259).

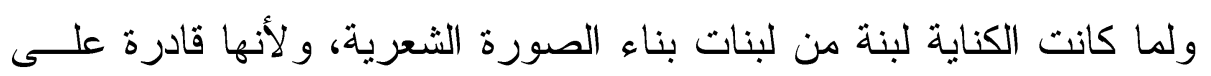

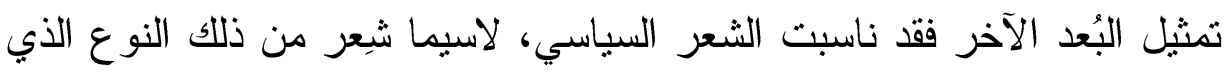

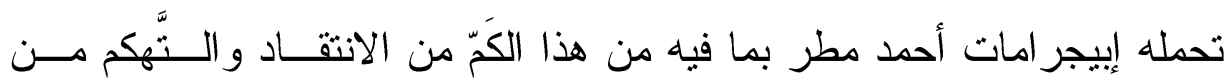
السلطات و الحكومات، وحتى يتفادى الرُّقباء، يقول: ترك اللص لنا ملحوظة فوق الحصير جاء فيها لعن الله الأمير لم يدع شيئًا لنا نسرقه الميز ....

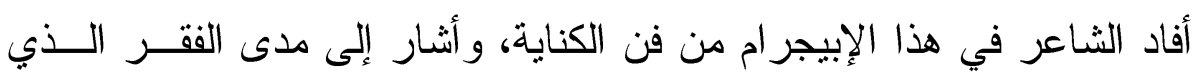

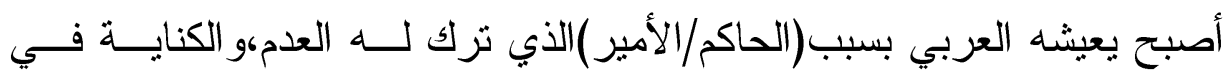

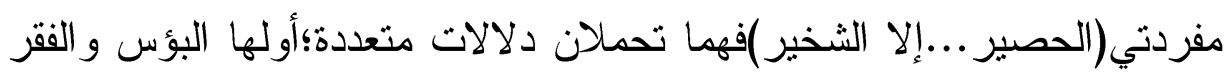

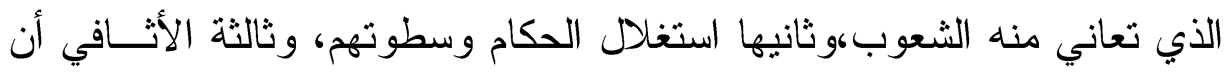

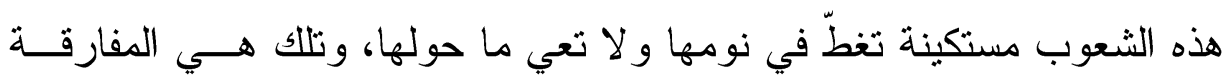

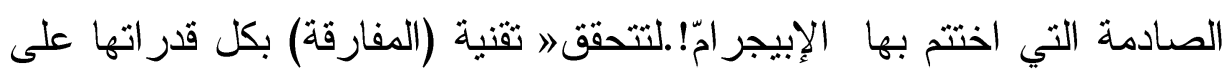

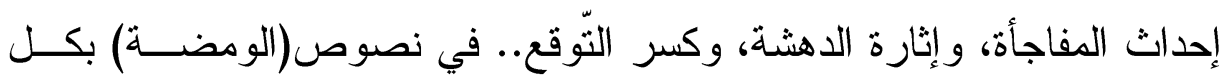

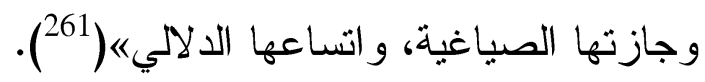


وفي إبيجر ام آخر يصور حجم المعاناة والفقر الثديدين اللـــين يتجرعهــــا الشعب، وذلك من خلال اعتماده على كنايتين؛ الأولى:حاول الثاعر من خلالها رسم صورة لمعالم الفقر ؛ فلا مأوى، و لا شبابيك تحجز البرد الثديد، وما من ونائن

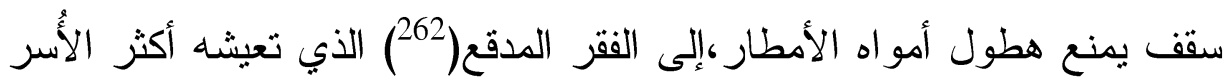

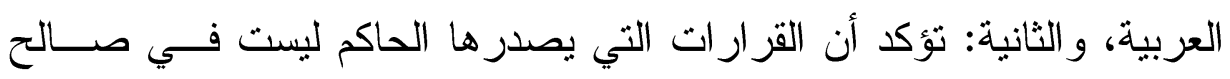

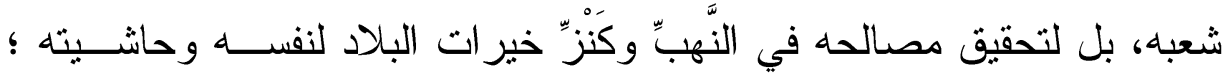

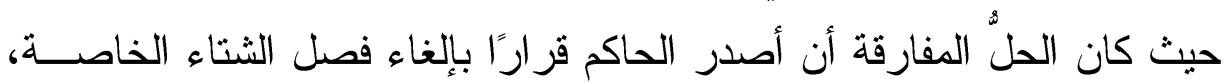
يقول:

بيتتا كان عر اء و الثبابيك هو اء قارس و السقف ماء فشكونا أمرنا عند ولي الأمر فاغتَّم و نادى الخبر اء و جميع الوزراء

$$
\text { ثم بعد الأخذ و الرّد }
$$
صباحًا ومساءً

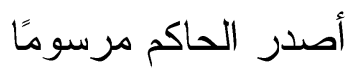
بإلغاء الثتاء! (263).

و أحيانًا تستشف الكناية من خلاءل التشبيهات البليغة المتتالية التـي تصـــِّرّ

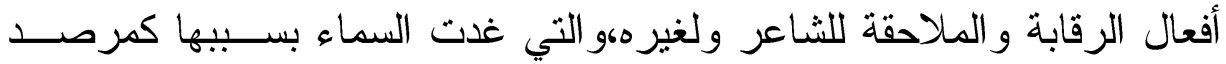

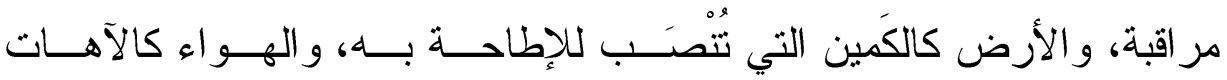
و الضغائن، ومن ثم يتساءل الثاعر مستتكرًا هل وطن هذا؟ ـ لاحظ أنه يجعل لأل 
اسم الإشارة بعد الاسم المُشار إليه، وفي هذا كله كناية عن شعوره بالغربــة و

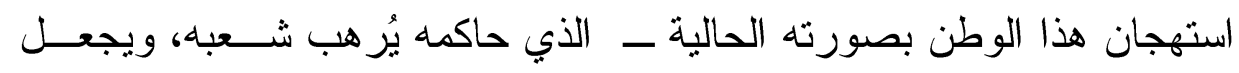

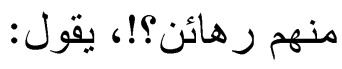
هل وطن هذا الذي من رهن حاكمه مُر اهِن و أهله رهن رهائن؟ هل وطن هذا الذي سماؤه مر اصد و أرضن كمائن? هذا الذي هو اؤه الآهات و الضغائن. (264) الضي ويلح كثيرًا على فكرة الموت المحيط نتيجة المُلاحقة للشعب، و اليــأس مــن

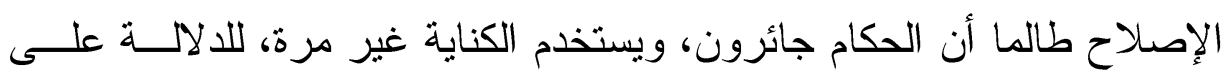

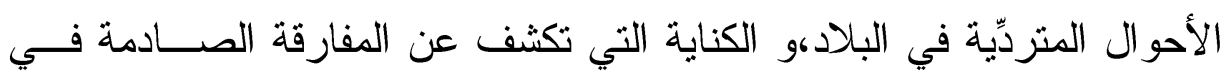

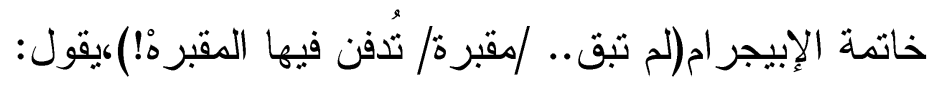
لم تبق في أوطانتا المطهَّرَه

$$
\begin{aligned}
& \text { مقبره } \\
& \text { تُفن فيها المقبرهٌ!(265). }
\end{aligned}
$$

ويرفض استشلام الثُعوب العربية لحكامها و استبدادهم، وكذا تبعيــة الحكــام

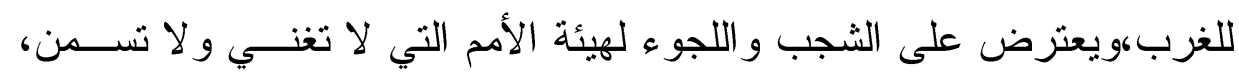
يقول في كناية معبِّرة وطريفة لما تحمله من مفارقة:

$$
\begin{aligned}
& \text { أسرتتا مؤمنةٌ } \\
& \text { تطيل من ركو عها } \\
& \text { تطيل من سجودها } \\
& \text { وتطلب النصر على عدوها } \\
& \text { من هيئة الأمم!(266) }
\end{aligned}
$$


ويشير في الإبيجرام الآتي الموجز لفظًا، والمكثَّف معنىً، إلى فَقِّّْ الحريات

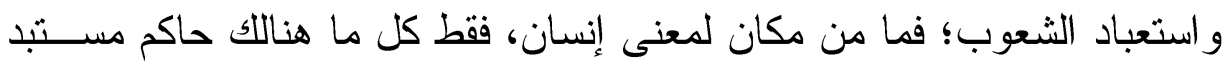

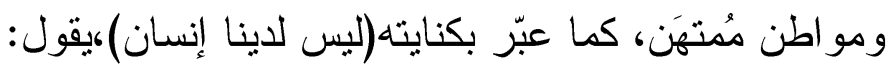

$$
\begin{aligned}
& \text { الفرد في بلادنا }
\end{aligned}
$$

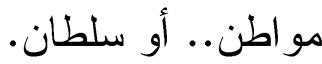

$$
\begin{aligned}
& \text { ليس لدينا إنسان(267). }
\end{aligned}
$$

و الكناية في الإبيجر ام الآتي(لا يعرف الموتُ شعرًا/لا يعرف الموتَ شاعر) توضح أنه يعلم ما يتوجب عليه حيال رسالته ومو هبته، يقول:

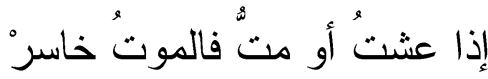

$$
\begin{aligned}
& \text { فلا يعرف الموت شعرًا }
\end{aligned}
$$

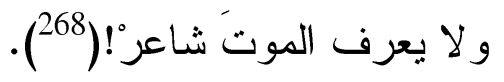

$$
\begin{aligned}
& \text { ويقول الثاعر: } \\
& \text { "قال أبي: } \\
& \text { في أي قطر عربي أبي } \\
& \text { إن أعلن الذكي عن ذكائه } \\
& \text { فهو غبي!" (269). }
\end{aligned}
$$

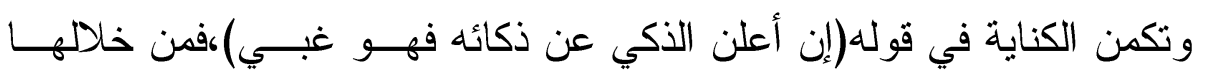
يوضح أنه في الوطن العربي لا يُقَّر النابغين ؛ فإذا أعلن الذكي عن ذكائه فهو

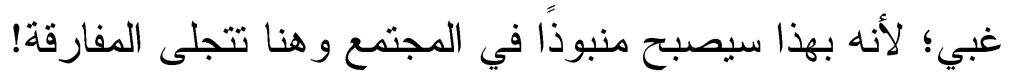
ويقول في إبيجرام موجز ومعبر كما الرشقة:

$$
\begin{aligned}
& \text { "صباح هذا اليوم } \\
& \text { أيقظني مننبه الساعة }
\end{aligned}
$$

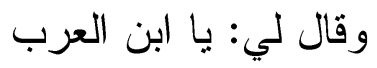

$$
\begin{aligned}
& \text { قد حان وقت النوم!" (270). }
\end{aligned}
$$


يتبدَّي في الإبيجرام السابق دور الكناية(وقال:..قد حان النوم!)التي لم تكــن

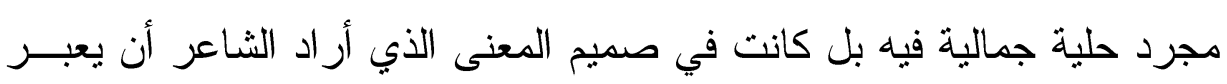

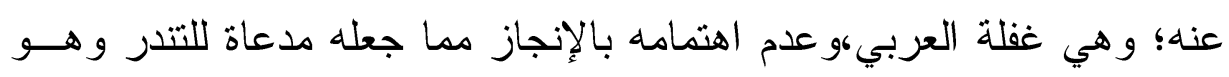
يصحو ليخفو !، وهذا من قبيل الصدمة الإدر اكية(271).

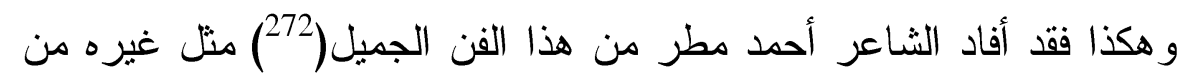

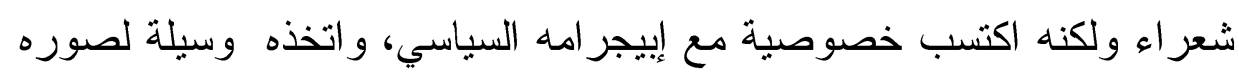

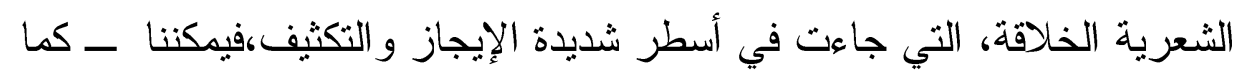

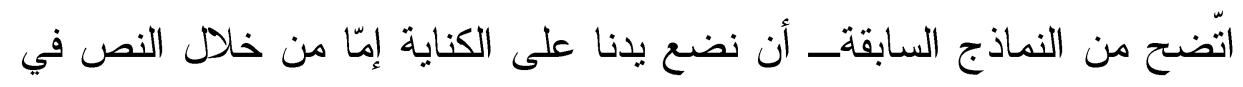

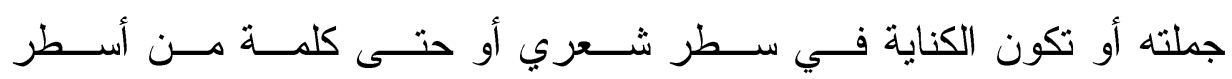

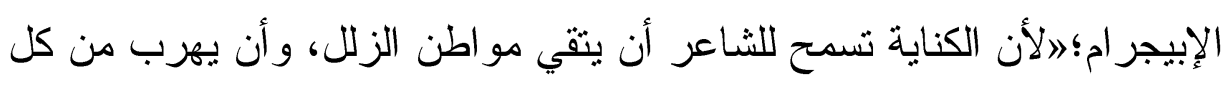

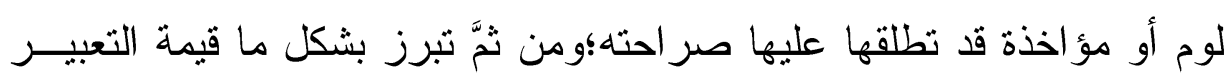

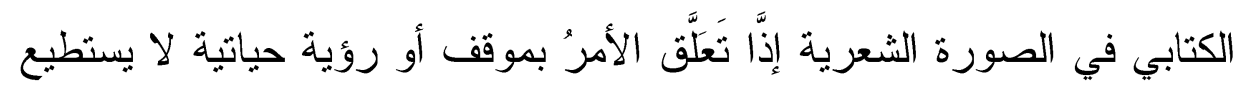

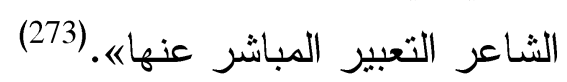

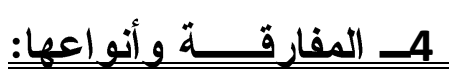

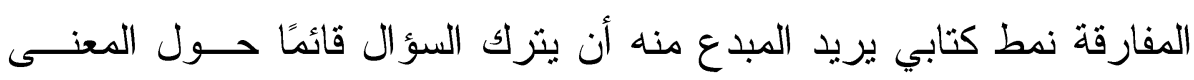

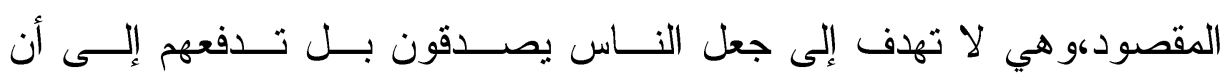

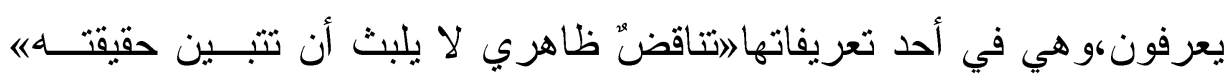

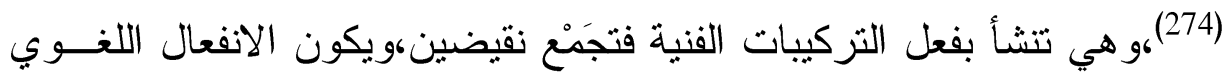

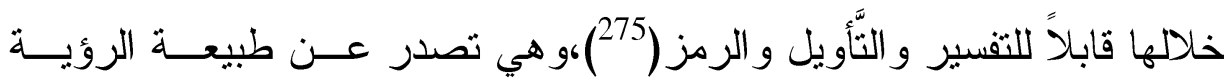

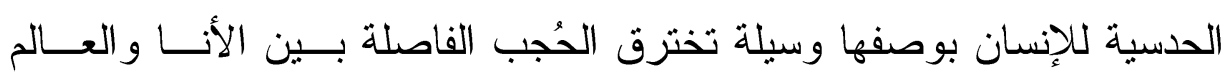

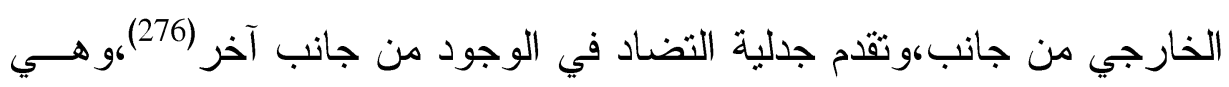
مزيج من الألم و التسلية (277).

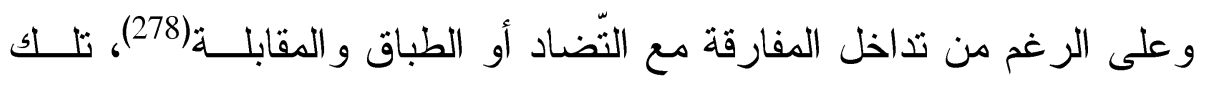

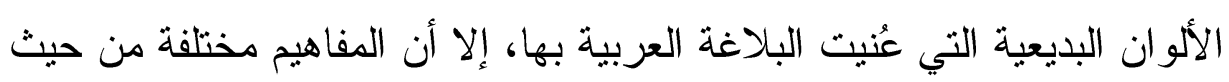


البناء الفني و الوظيفة الدلالية(279،هالمفارقة لغة شــعرية لا مجــرد مُحسِِّنـن

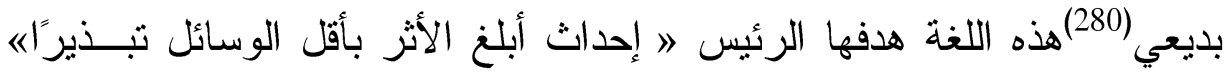

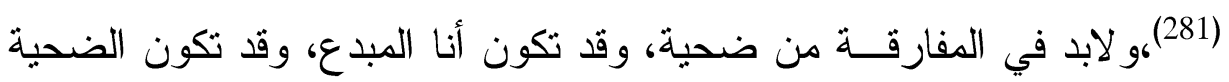

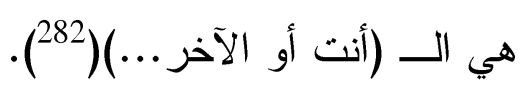
و أحمد مطر من أكثر الثعر اء المعاصرين إفادة من هذا النسق المفارقي في

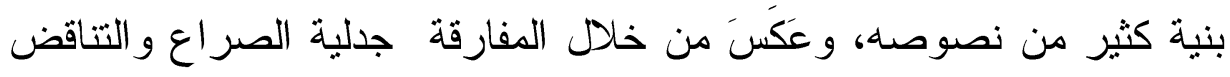

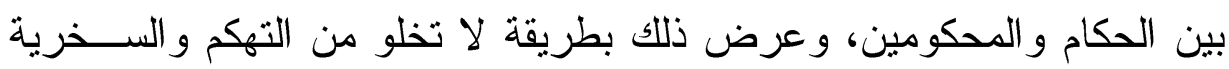

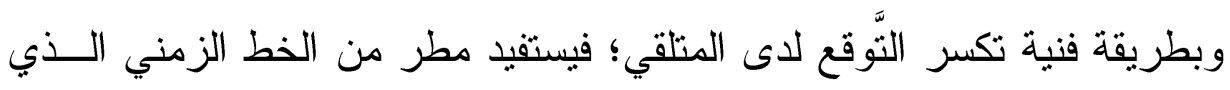
تستغرقه قر اءة الإبيجر ام ليأتي في نهاية هذا الخط بمفردة تكون مَركز المعنى

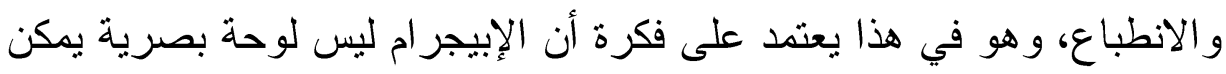

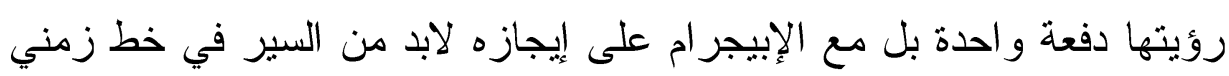
متتابع باتجاه النهاية،ومثال ذلك قوله:

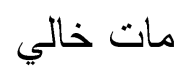

$$
\begin{aligned}
& \text { هكذ!!! } \\
& \text { دون اغتيال } \\
& \text { دون أن يُشنق سهوًا! } \\
& \text { دون أن يَسقط بالصدفة، مسمومًا } \\
& \text { خلال الاعتقال! } \\
& \text { مات خالي } \\
& \text { مينة أغرب مما في الخيال! } \\
& \text { أسلم الروح لعزر ائيل سرًا }
\end{aligned}
$$

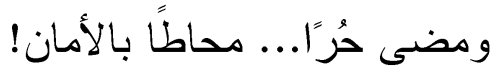

$$
\begin{aligned}
& \text { فدفنّاه } \\
& \text { وعدنا نتلقّى فيه من أصحابنا }
\end{aligned}
$$




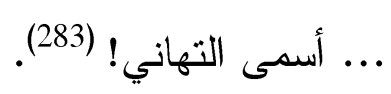

فنجد المفارقة قد بُنبت اعتمادًا على اتجاه السرد الزمني، فجاءت تصاعدية في ذكر الأحداث، ولكن القفلة الأخيرة في النص أدت إلى إنى تحقيق فهر جديد للحكاية

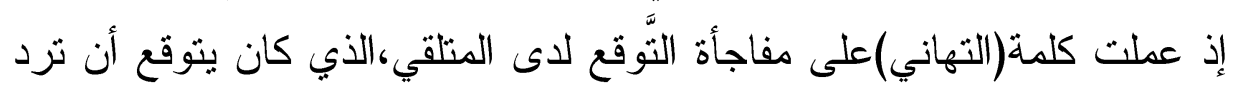

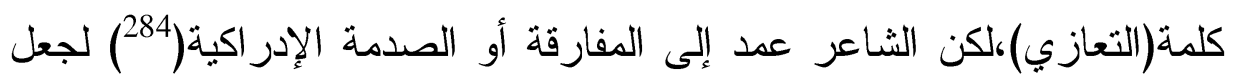

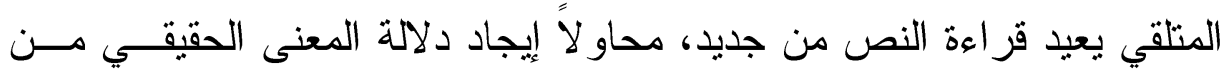
وراء ذلك،ولعل المفارقة نشأت من أن جعل الثاعر الموت حتف الأنف أصبح

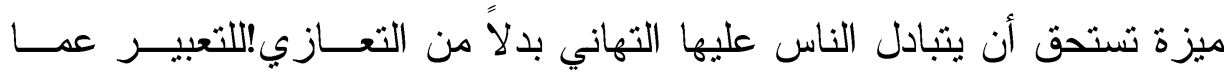
أعطاها الله من نعمة الفوت من استبداد الحُكام وتتكيلهم بهر.

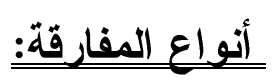

تعددت المفارقة من حيث ورودها في إبيجر امات الثاعر(285)؛ وأشير إلــى

$$
\text { الأكثر شيوعًا منها: }
$$

\section{[4 - 4 1 المفارقة النلاشخصية:}

و لا يلتقت هذا النوع من المفارقة للشخصية التي يقدمها صـــاحب المفارقـــة وتكون سمة المتكلم التّعقل وينطلق على سجيته دون تعاطف (286)،ومن أمثلة هذا النوع إبيجر ام أحمد مطر التالي، يقول:

$$
\text { إبليس فكّر مره }
$$$$
\text { في أن يطور شغله }
$$$$
\text { ليصير أكثر مُجرما }
$$$$
\text { ويصير أكثر آثما ليصنير }
$$$$
\text { ويصير أكثر مُرهًِا }
$$

ومنافقًا ومُكذبًا 


$$
\begin{aligned}
& \text { ولَدَى تَصَلُْب جَذرِِ } \\
& \text { ولدى تفتح زهر هِ } \\
& \text { دفن اسمه في صدره } \\
& \text { وغدا يسمى حاكما!(287) }
\end{aligned}
$$

في هذا النص استحضر الثاعر صورة الحاكم المستبد غاية الاســتبداد فـي الو اقع، فاستلهم أسو أ مَتل للشر في الدنيا والآخرة؛وهو إبليس، ويجعل إبليس -

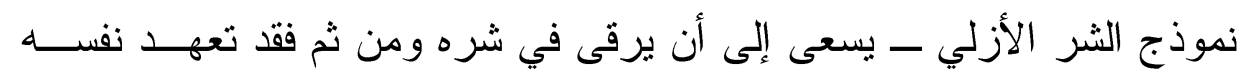
بالاستز ادة من الشر، ولما تقدّم غيّر رتبته ولقّب نفسه لدرجة الشر التي تطور

$$
\text { إليها؛و هي هنا المفارقة الصارخة فالحاكم أرقى من إبليس شرًا! }
$$

\section{[4- 2] مفارقة الاستخفاف بالأت:}

وتقوم على فكرة صاحب المفارقة المَقَّعَ، ولكنه قناع تأثيره إيجابي،و غالبًا ما يلجأ صاحب شخصية المفارقة إلى الاستخفاف بذاته، ويحطٌ من قدر ها،ويصير ما يوحيه عن نفسه جزءًا من وسيلة المفارقة لديه(288)،ومن أمثلة هذا النوع من ونه

$$
\begin{aligned}
& \text { المفار قة،قوله: } \\
& \text { أنا في الواقع } \\
& \text { رجل.... كلا } \\
& \text { امر أة.... كلا }
\end{aligned}
$$$$
\text { أنثى مسترجله؟... كلا }
$$$$
\text { رجل مائع؟ }
$$$$
\text { كلע... }
$$$$
\text { كل الأجناس لها رأي }
$$$$
\text { ولها هدف كولها دافع }
$$$$
\text { وأنا طول حياتي خانع }
$$

$$
\text { أنا في الواقع }
$$




$$
\text { جنس رابع(289) }
$$

فيقام الثاعر نفسه في صورة شخص ساذج ومُهَشَش، يسير من دون رؤية أو

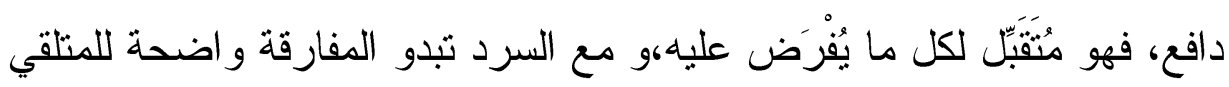

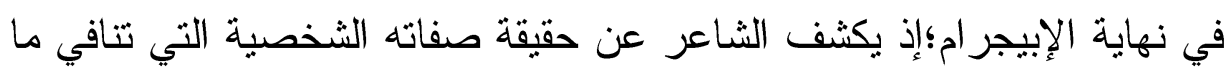

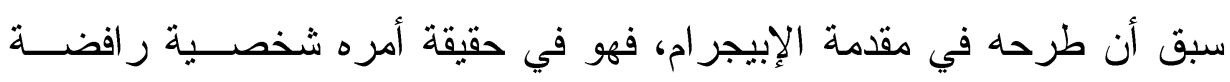

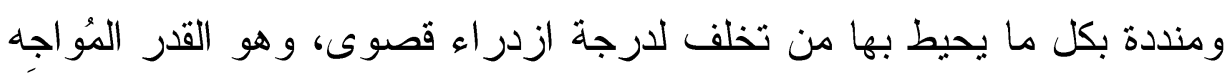

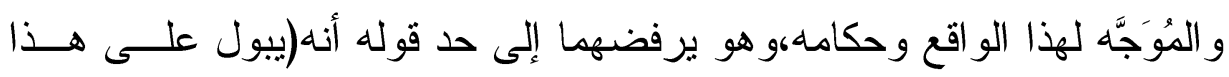

$$
\begin{aligned}
& \text { الو اقع و....)،يقول: } \\
& \text { أنا في الو اقع ون } \\
& \text { من سبع سماو ات و اقع لقع } \\
& \text { أرجو أن تبتعدوا عني سني } \\
& \text { لأبول على هذا الو اقع! تبأعدوا عن } \\
& \text {...9 } \\
& \text { ماذا أخشى؟ } \\
& \text { موتي مات لشدة موتي } \\
& \text { وحياتي... في الوقت الضائع! (290) } \\
& \text { [4- 3] مفارقة (الفحاجة: }
\end{aligned}
$$

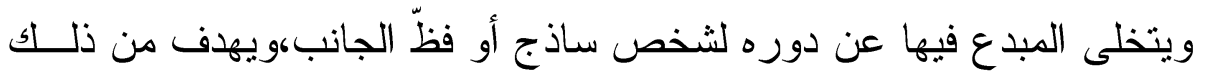

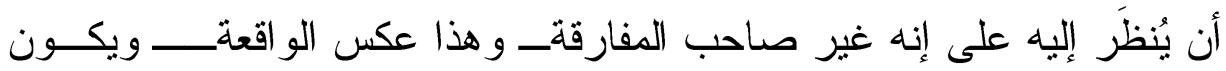

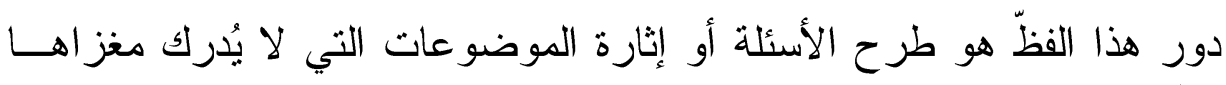

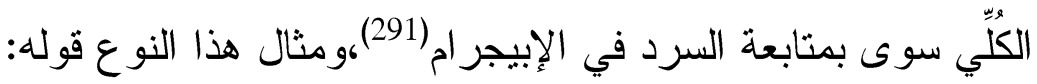

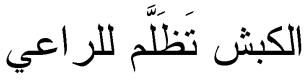

$$
\begin{aligned}
& \text { مادمت تفكر في بيعي لفي لفري } \\
& \text { فلماذا ترفض إثباعي؟ }
\end{aligned}
$$




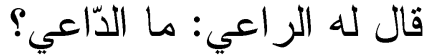
كل رعاة بلادي مثلي وأنا لا أشكو و وأداعي بالحدي مني احسب نفسك ضدن قطيع

$$
\text { و أنا الإقطاعي!(292). }
$$

وصاحب المفارقة في هذا الإبيجر ام تَخلّى عن مكانه، وتــرك الأمــر (لكبش

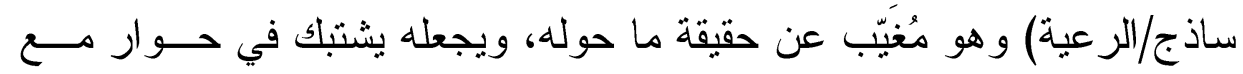
(أحد الرعاة/الإقطاعي/الحاكم)،عن سبب عدم إثباعه مادام(يريد بيعه/العِمَالــــة للغرب)، وخلال هذا الحوار يكثف صاحب المفارقة عن الصفقات الدنيئة التي لئي

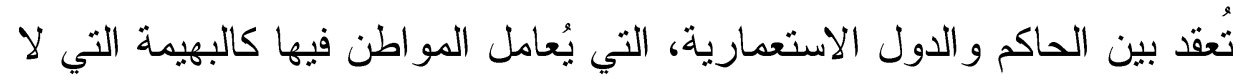
حول لها ولا قوة، وما يتلقاه المواطن هو جر ائر الصفعات لا فو ائد الصفقات!. [4- 4] المفارقة الار امية:

و هذه المفارقة أبلغ أثرًا من الأنواع الأخرى، وهي تتبدّى عندما يجد الجمهور

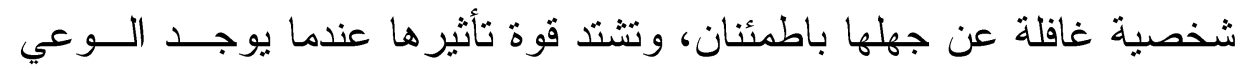

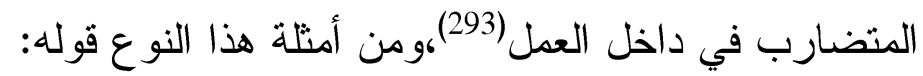

$$
\begin{aligned}
& \text { ألقيتَ خطابًا في النادي } \\
& \text { وتلوت قصائد في المقهى } \\
& \text { ونقدت السُّطة في المطعم } \\
& \text { هل تحسب أنَّا لا نعلم؟! في المطع } \\
& \text { !.....- } \\
& \text { في يوم كذا... } \\
& \text { حاورت مذيعًا غربيًا } \\
& \text { وعرضت بتصريح مبهر }
\end{aligned}
$$




$$
\begin{aligned}
& \text { لغباوة قائدنا المُلهَمَ } \\
& \text { هل تحسب أنَّاّ لا نعلم؟! } \\
& \text { !.....- } \\
& \text { إن مكلكك هذا مُتخَمَ! } \\
& \text { هل عندك أقو ال أخرى؟ } \\
& \text { !.......- } \\
& \text { !........- }
\end{aligned}
$$

في هذا النص يظهر المتّهم/الضحية الذي لا يدري ما السبب وراء اعتقاله،

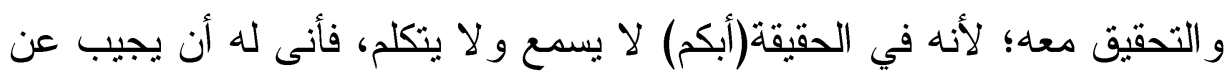

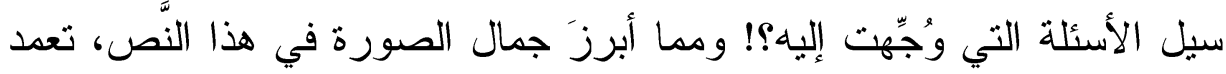
الثاعر ترك الحقبقة خفيةً إلى أن قام بكثفها في آخر سطر من الإبيجر ام وهذه التها

$$
\text { الحقيقة أن صاحب المفارقة/أبكم! }
$$

و هكذا اسنطاع أحمد مطر بثقنية استخر اج المتلقي أن يُوظّف عنصر التنامي

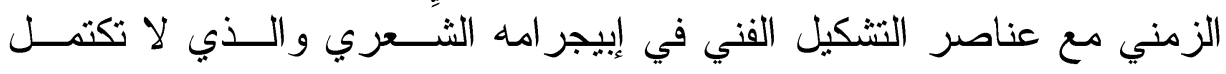

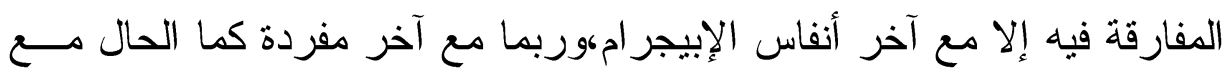

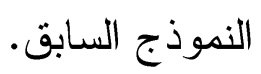

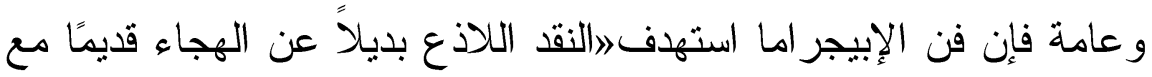

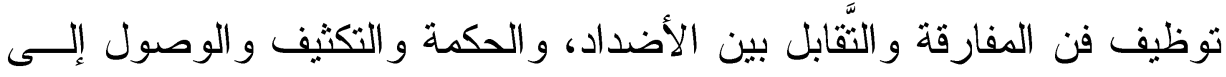

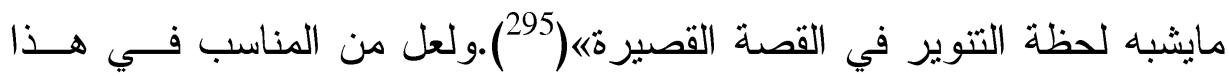


المقام أن نستحضر قولة عز الدين المناصرة عن ارتباط التوقيعـة بالمفارقــة

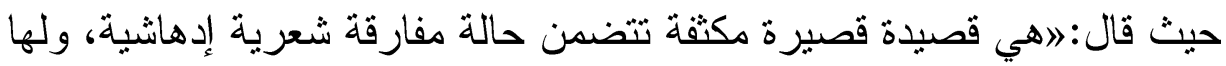

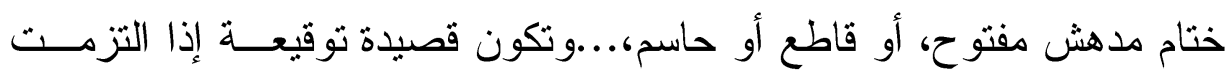

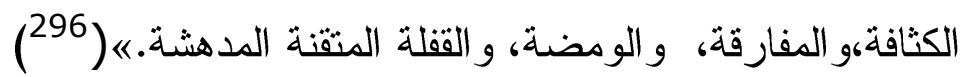

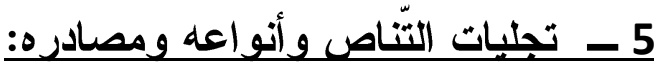

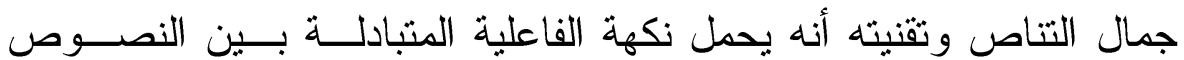

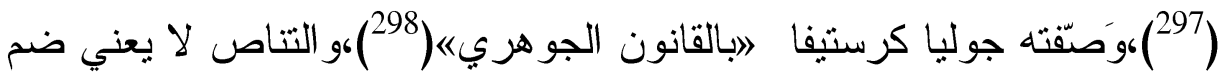

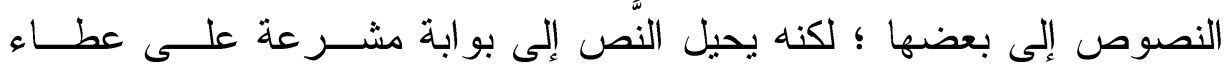

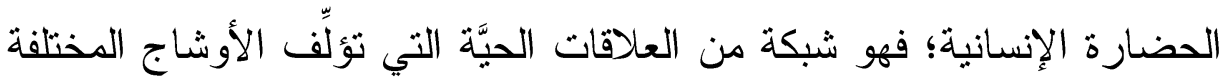

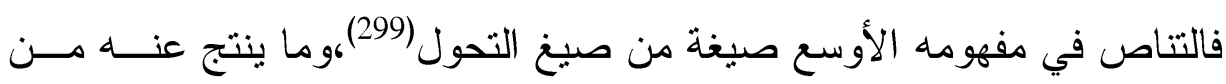

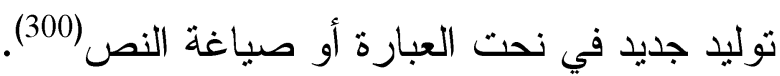

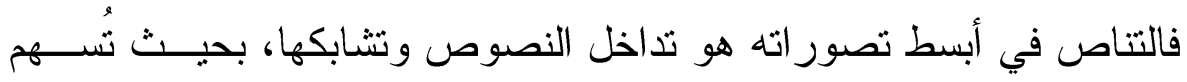

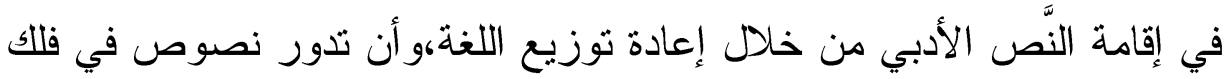

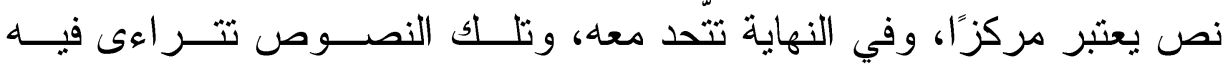

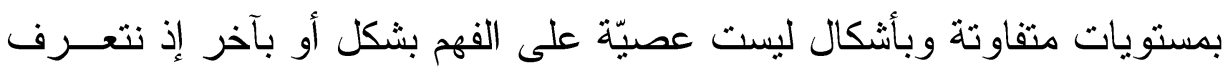

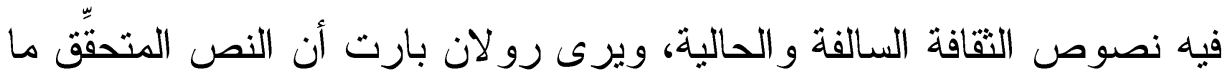

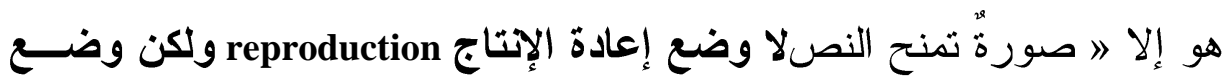

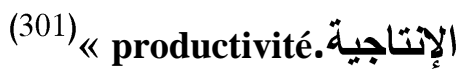

وللتناص دوره الفاعل في إثراء النص دلاليًا ومعرفيًا بما يســـاعي مــن مقو لات السابقين أو اللاحقين بصورة ضمنية(302)،إضافة للقيمة الجمالية. ومع هذا فالتتاص ظاهرة لغوية تتأبَّى على الضبط و التقنين،لأن هذه الظاهرة

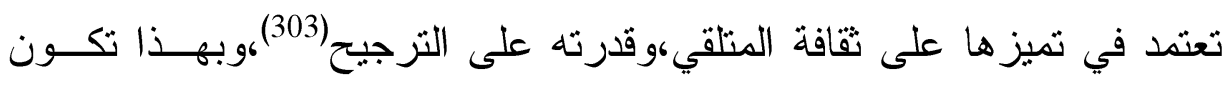

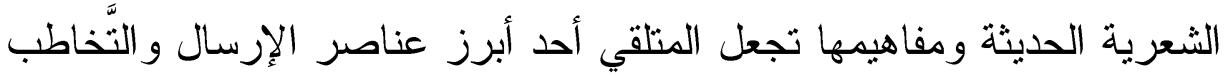


الأدبي، فهو أصبح قارئًا للنص ومنتجًا له،ومن ثم فالتتاص يحضــر بوسـاطة التأويل الخاص بـ(304). و عامة إن مصطلح التَّاص متعدد المفاهيم و الرؤى ـ ولن تسعه هذه الدر اسة

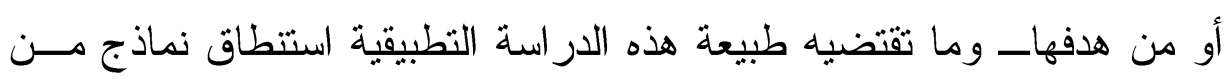

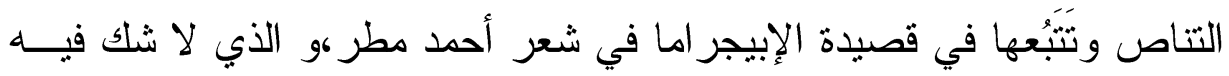

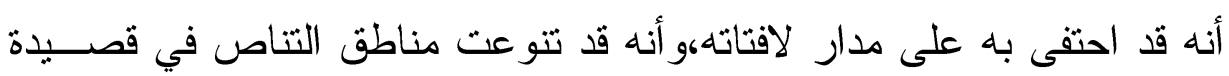

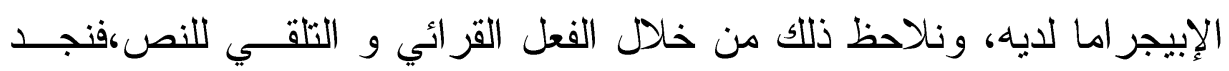

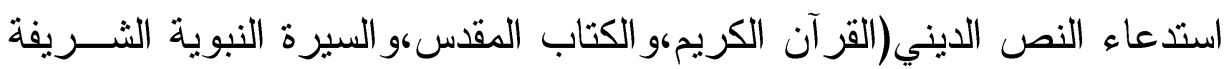

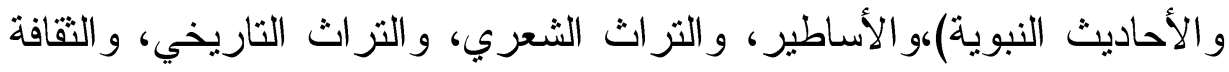

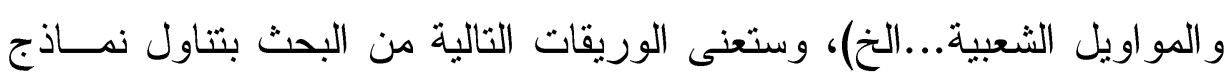
من التناص في إبيجر ام مطر ومصادره المختلفة. ومن تجليات التناص في إيبحر امات أحمد مطر :

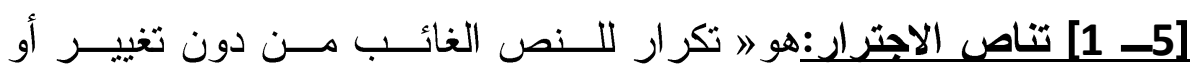
تحوير .ببسبب نظرة من التقديس و الاجتر ار لبعض النصــوص و المرجعيــات

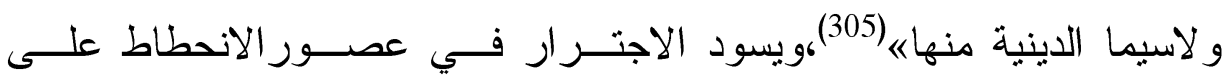
الأخص (306)ومن أمثلة تتاص الاجترار قول أحمد مطر : وصباحها يعلو الونان ألا أيها الليل الطويل بعل ألا انجل يأيها الليل الطويل و الليل في النزع الأخير هوى بقوته الو هن.... فعرشه يُلقى غدًا ليباع في سوق النهار بلا ثمن (307) 
فالثاعر اجترَّ أحد أشطر معلقة امرئ القيس الكندي،و هو:(308) ألا أيها الليل الطويل ألا انجل.... فالثاعر أتي به في إيبجر امه دون أن يُخخل عليه إضافة تُذكر ،وهذا النمط من

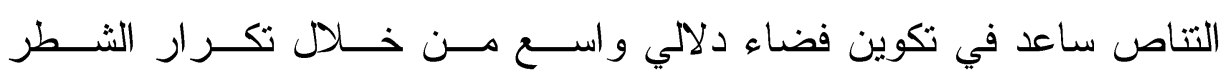

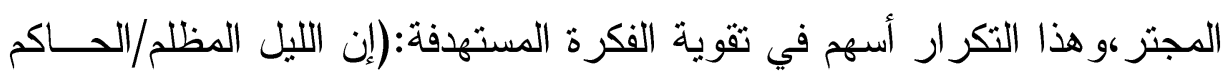

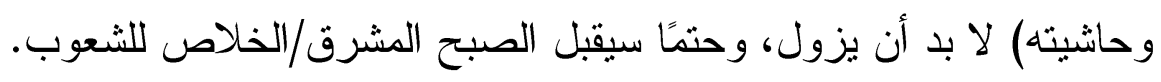

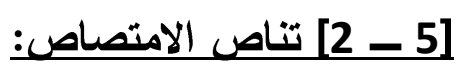

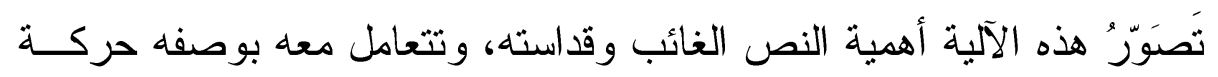

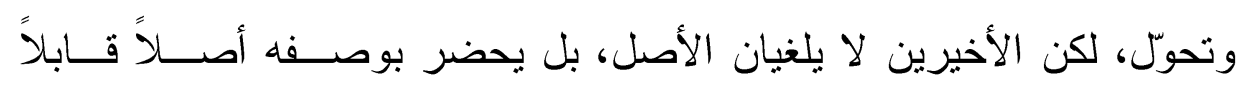

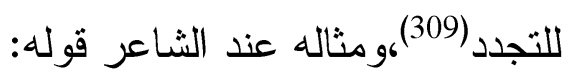

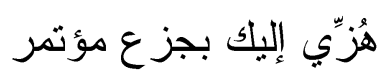

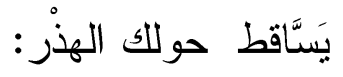

$$
\begin{aligned}
& \text { عاش اللهيب }
\end{aligned}
$$

(310) (...

إذ امتص الشاعر هذا المقطع من قوله عزَّ وجل:هوز هزي إليكك بجذع النخلــة

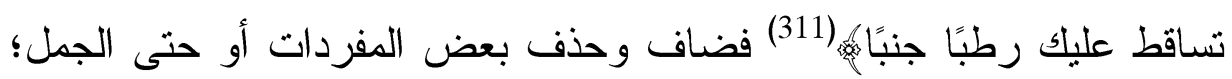

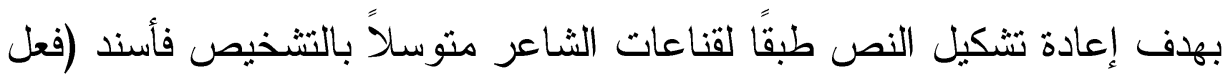

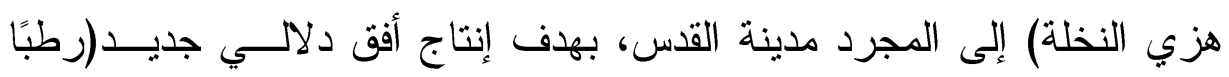

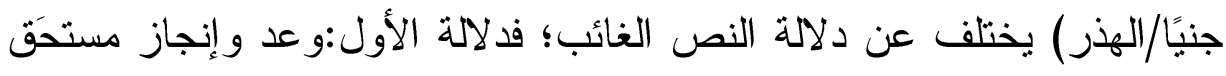

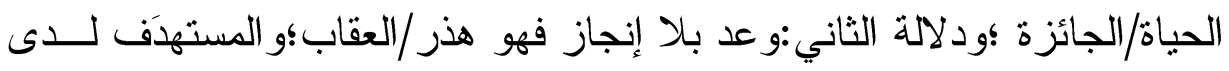

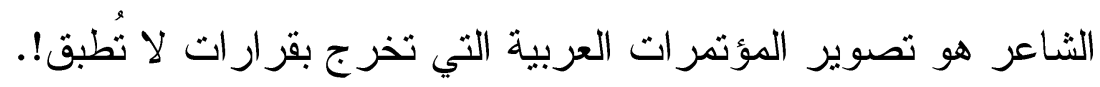

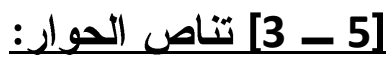

هو أكثر الأنماط احتو اءً لمفهوم قر اءة النص الغائب؛ لأن قو امه قناعة تحطم

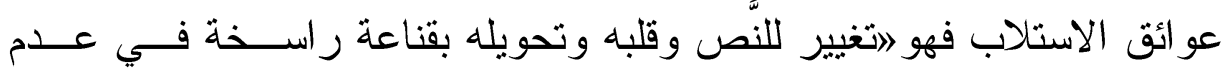




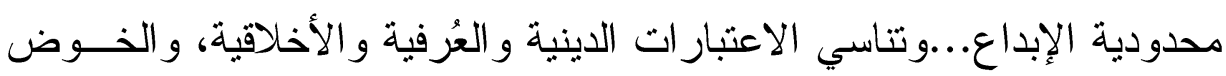

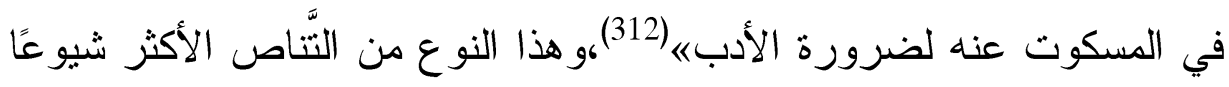

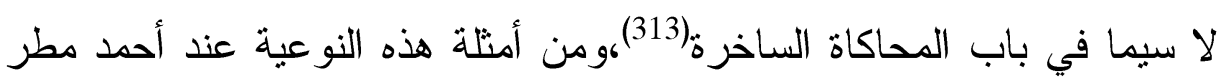

$$
\text { قوله: }
$$

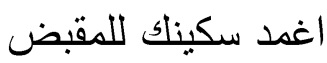

$$
\text { و اقبض أجرك من أصحاب الفيل }
$$

لا تأخذك الر أفة فيه

$$
\text { بدين البيت الأبيض! }
$$

نفذ رؤياك و لا تجنح للتأويل الابطن

لن ينزل كبش... لا تأمل بالتبديل

$$
\text { يا مو لانا }
$$

إن لم تذبحه نذبحه

$$
\begin{aligned}
& \text { فهذا زمن آخر } \\
& \text { يفدي فيه الكبش } \\
& \text { بإسماعيل! (314) }
\end{aligned}
$$

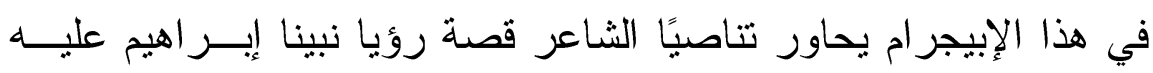

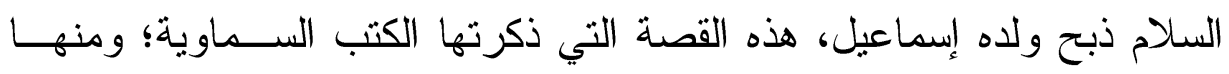

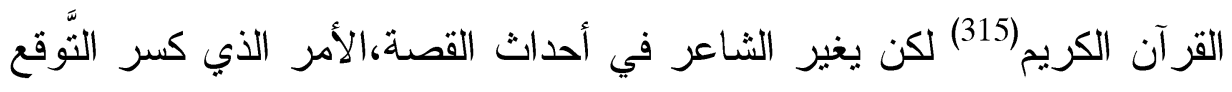
لاى المتلقي، مما أسهم في ظهور بُعد دلالي جديد،و ساعد الحوار على تبــديل

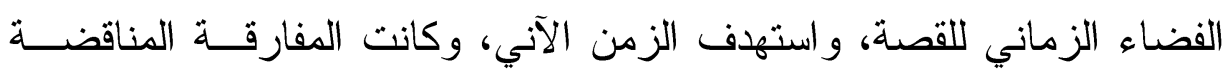
للنص الأول (فهذا زمن آخر/يُفَيَي فيه الكبش/بإسماعيل!). 
وهو من أكثر المصادر التي فاء الشاعر إليها فاستلهمه اقتباسًا وتتاصًا في

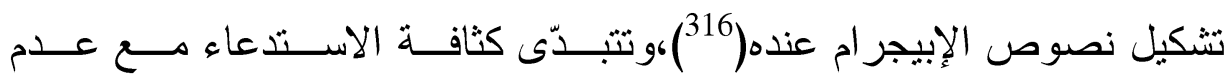
الاسترسال في وصف مشهد النص القر آني حتى لا بستغرق المتلقي في عو المه الهـ

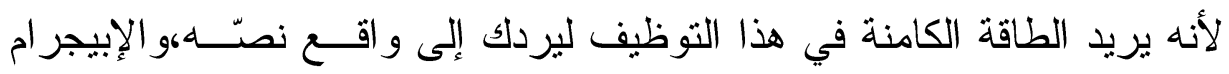
الآتي يمثّل لهذا النمط من الاقتباس يقول:

$$
\text { "ترأت في القرآن: }
$$

فأعلنت وسائل الإذعان:

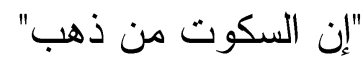

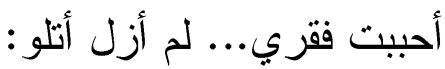$$
\text { وتب }
$$

"ما أغنى عنه ماله وما كسب"

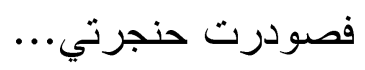$$
\text { وصودر القرآن }
$$

لأنه.... حرضني على الثغب! (317)

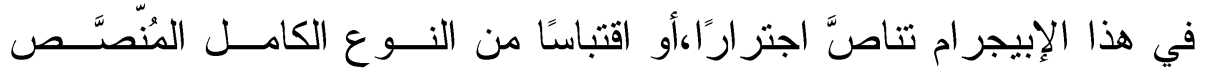

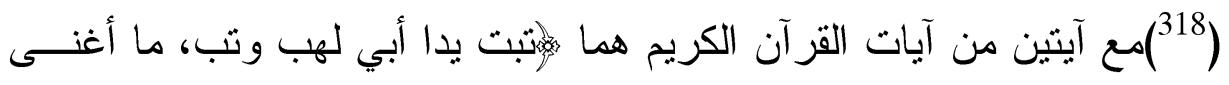

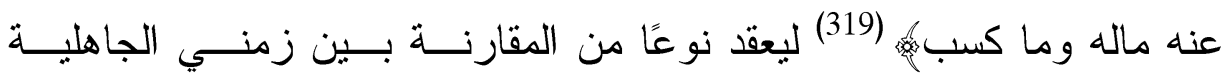
و الحاضر، فقد اثترك كلاهما في فكرة حيازة فئة قليلة من الناس الأموال وقمة لهن

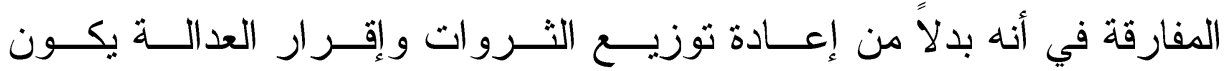
الحل:(صودر القرآن) دلالة على القمع الثديد، وتعكس المفارقة الإحباط الأشد الذي لدى الثاعر !. 


$$
\text { ومثاله أيضًا قوله: ولما أوى الفتية المؤمنون }
$$

$$
\text { إلى كهفه }
$$

كان في الكهف قبلهم مخبرون!(320) فيعيد الثاعر قراءة الآية الكريمة فئإذ أوى الفتية لكهفه فقالوا ربنا آتنا مــن

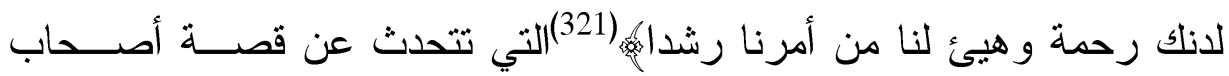

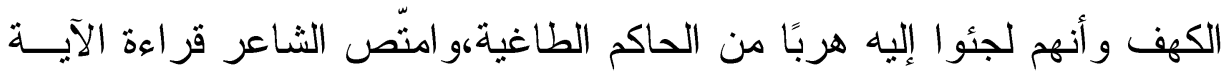

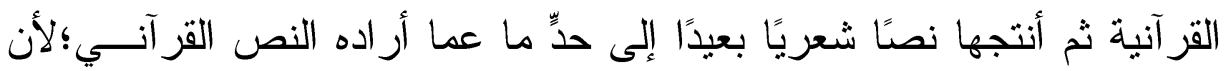

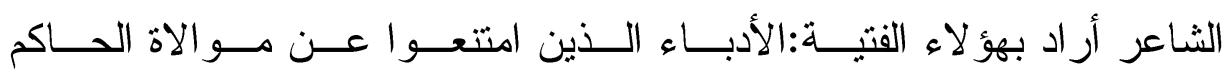
و السلطة،واختلف رمز المكان في الإبيجرام؛لأن الثاعر لم يقصد بالكهف مكانًا

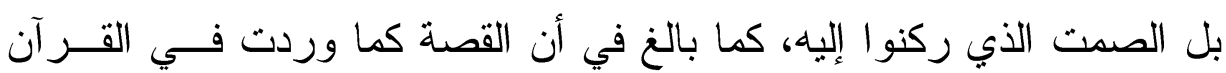

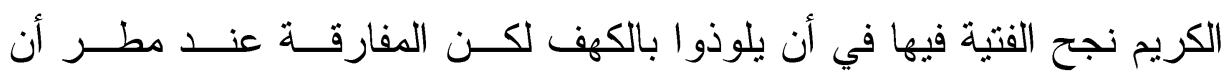
المخبرين سبقو الأدباء وحاصروهم(كان في الكهف قبلهم مخبرون!).

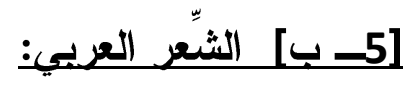
تتاص الثاعر في بعض إيجر اماته مع بعض المعاني المتفــردة و الأبيــات

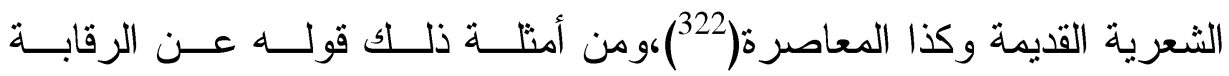

$$
\text { و الملاحقة: }
$$

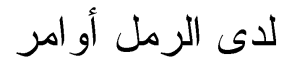
أن يماشيك لكي يرفع بصمات الحو افر خفف الوطء قليلاً فأديم الأرض من هذي العساكر 
فقد عبّر أحمد مطر من خلال تراث الأو ائل،واستمد من مظاهر البيئة العربية

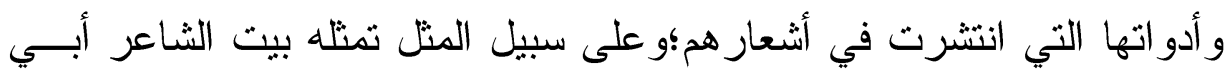
العلاء المعري،و هو البيث القائل:أنها: خفف الوطء ما أظن أديم الــأرض إلا من هذه الأجساد العـاد و هو لم يفعل لمجرد استرجاع مقو لات المعري الشعرية الفلسفية،بل للإفــادة

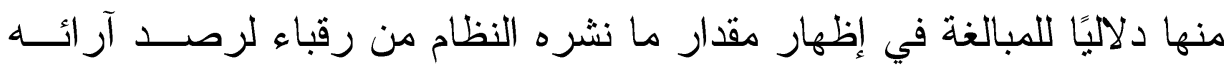
المناوئة للسلطة.

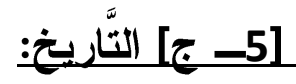
يستدعي الثاعر حدث أو قصة أو اسم دون التفاصيل،ويدرجه في الإبيجرام ويَّرك للقارئ حرية استحضار الحدث، ومثل ذلك قوله:

$$
\begin{aligned}
& \text { ها هو ذا(يزيد) } \\
& \text { صباح يوم عيد } \\
& \text { يخضِّب الكعبة بالدماء من جديد } \\
& \text { إني أرى مصفحات حولها } \\
& \text { تقذف بالنار و الحديد } \\
& \text { وطائر ات فوقها } \\
& \text { تقذف بالمزيد(325) }
\end{aligned}
$$

فالثاعر يستدعي إحدى الأحداث فــي التـاريخ الإســلامي،وهي هي الحادثــة

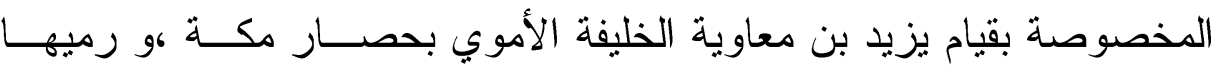

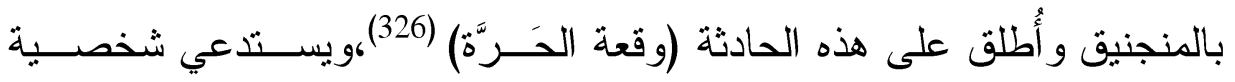

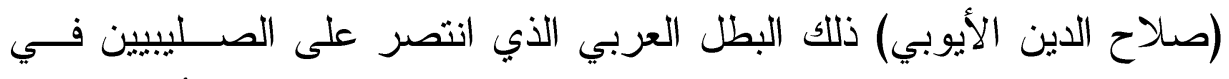

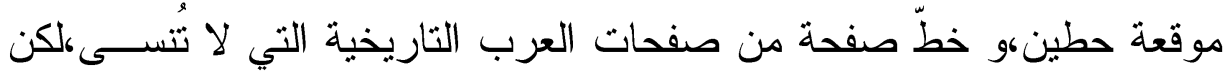

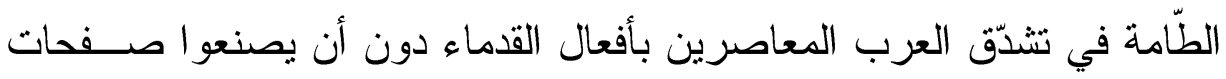

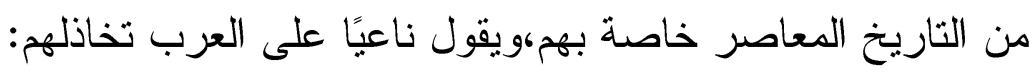




$$
\begin{aligned}
& \text { و غاية الخشونة، } \\
& \text { أن تندبو ا: } \\
& \text { " قم يا صلاح الدين،قم"، } \\
& \text { حتى اشتكى مرقده } \\
& \text { من حوله العفونه، } \\
& \text { كم مرة في العام توقظونهْ، } \\
& \text { كم مرة على جدار الجبن تجلدونهْ، } \\
& \text { أيطلب الأحياء من أمواتهم معونه(327) } \\
& 6
\end{aligned}
$$

مفادها أن يكون للكلمة معنيان؛ فيقصد الأديب إلى المعنى البعيد ويورِي عنه بالقريب(328)، و لا يتغيا التزيين، بل الانزياح بالقدر الذي يجعل النص حــافلاً بالإدهاش الجمالي والاقتصاد اللغوي. وطبحي أن الشعر السياسي يتطلب اللجوء لفن التورية حتى يقي المبدع نفسه من المساءلة، لكن مع شاعر مثل مطر الذي قصر شعره على الغرض السياسي

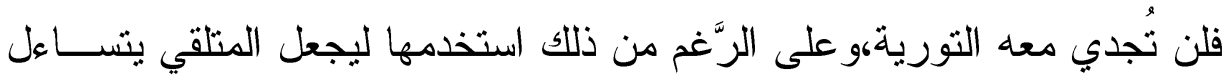

$$
\begin{aligned}
& \text { عن دلالتها مثل التورية في كلمة(نظام) في قوله: }
\end{aligned}
$$

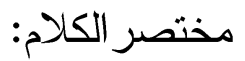

$$
\begin{aligned}
& \text { إني إذا ما نظر الحاكم لي } \\
& \text { لا أشتهي الطعام! } \\
& \text { هذا نظام معدتي } \\
& \text { ولن بعيد صحتي }
\end{aligned}
$$

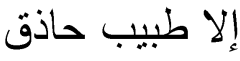

$$
\begin{aligned}
& \text { يفهم في نظامها } \\
& \text {... فيقلب النظام!(329) }
\end{aligned}
$$


فجاءت كلمة(نظامها) الثانية وما تلاها (النظام) في ترتيــب الســـاق، وكــأن

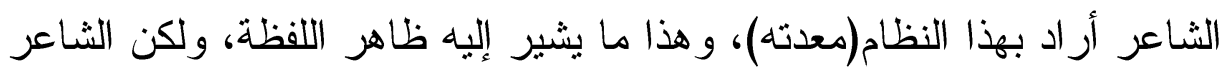

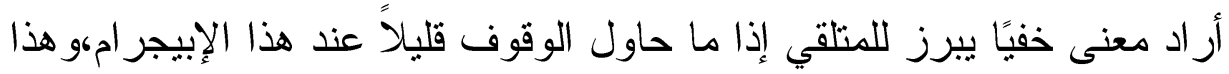

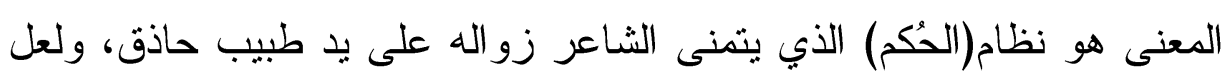

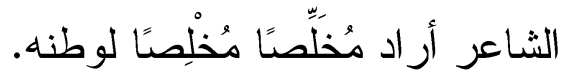
ومن الكلمات التي وردت في أحد الإبيجر امات وهي تحمل في سباقها تورية كلمة (القانون) الثانية في قول الثاعر: فأُخرجُ القانونَ من متحفه وأمسح الغبار عن جبينه أطلب بعض عطفه لكنه يهرب نحو قاتلي وينحني في صفه! يقول حبري ودمي: لا نتدهش لوش

من بملك (القانون) في أوطاننا

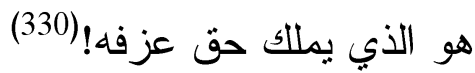
فلفظة (القانون) الثانية أر اد بها الثاعر آلة القانون المستعملة في العزف وأنى

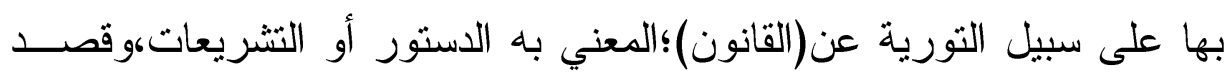

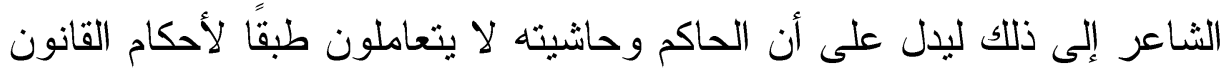

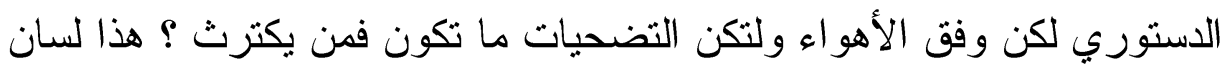

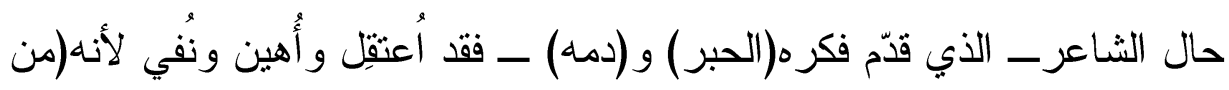
يملك "القانون" في أوطاننا/هو الذي يملك حق عزفه!). 


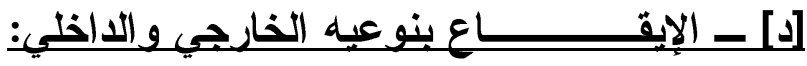

لم يتفق الباحثون حول مفهوم واحد للإيقاع(331) ويستخدم الإيقاع أساسًا في لئي

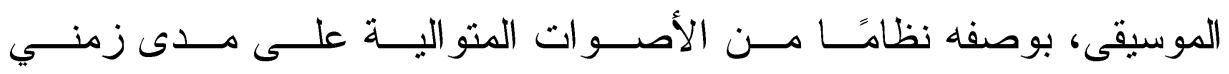

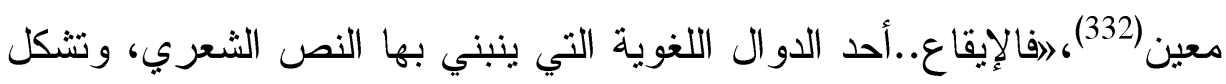

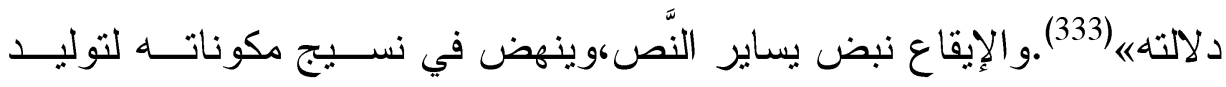
الدالة|(334) لقوته الإيحائية التي يبثها في السياق الذي يتكون من ألفاظ يختارها الثاعر لاعتقاده بتمكنها من إثارة المشاعر عند المتلقي. (335) و الإيقاع ميزة من ميراث الثعر العربي، وهو جوهر تعريف القدماء للشعر

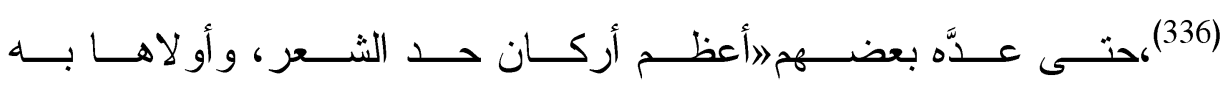

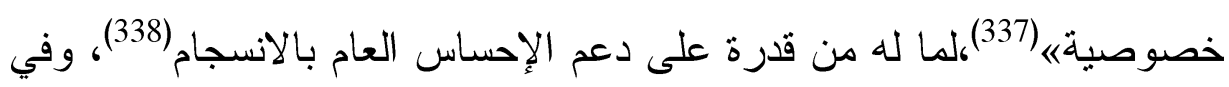
التعبير الفني عن العو اطف الإنسانية. (339) و الإيقاع بنو عيه؛الخارجي و الداخلي، يمثل البنية الرئيسة التي يتكئ الثاعر

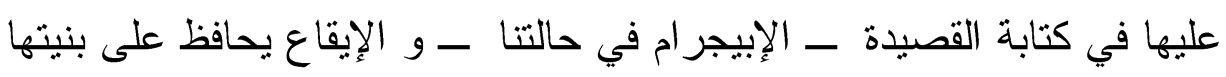

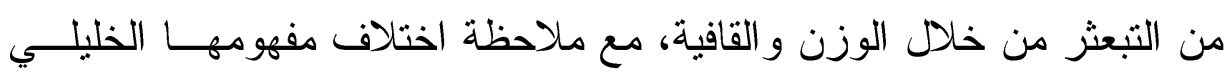

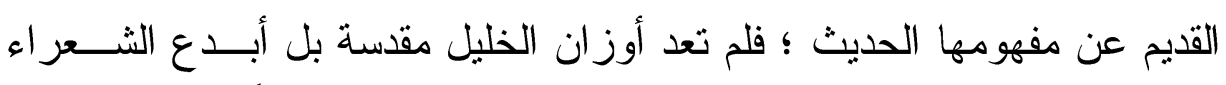

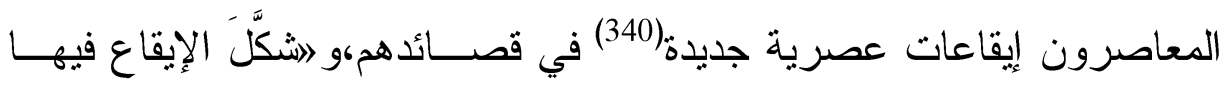

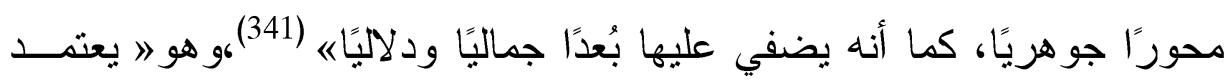

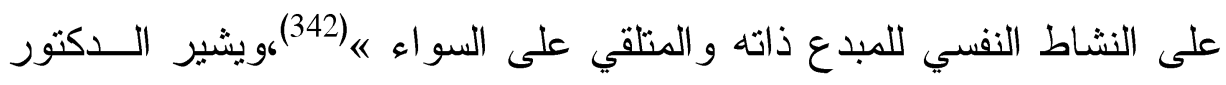

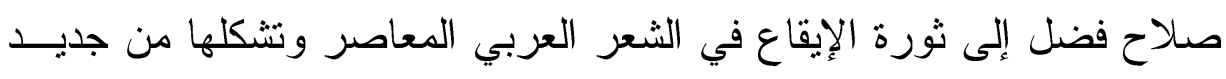

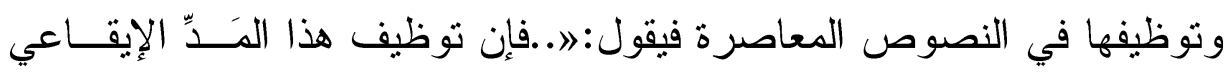

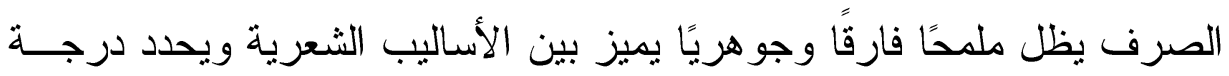
قربها أو بعدها من الغنائية التي تكاد تتمركز عن القطب الأول، كما يرتبط هذا

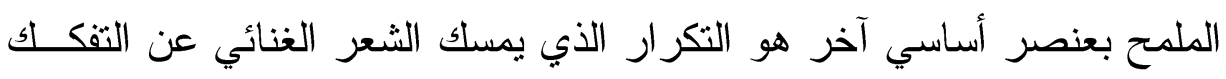
والانحلاله (343). 
وكما منتَّت بنية الإيقاع ركنًا مهمًا في الشعر العربي عمومًا، كذلك كانت في التها

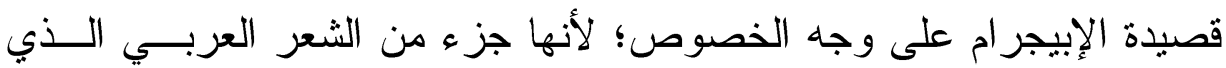

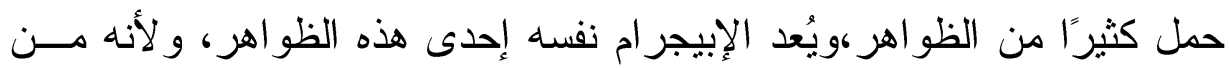

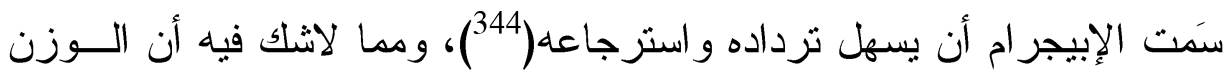
و الإيقاع من الأشياء التي قد تدعم هذا الجانب. وقد جاءت قصبدة الإبيجر ام محملة بالإيقاعات المختلفة، وقد اتَّكأت علــى الإنى تفعيلات بعينها؛ لذا تطرقت إلى تتاول بنية الإيقاع في قصيدة الإبيجــرام مــن الإنـ

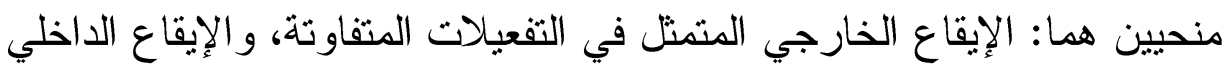

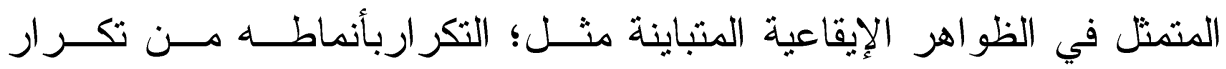
الحروف، و المفردات، و الجناس، و الطباق.

\section{لـ ــ أولاً: الموسيقى الخارحية}

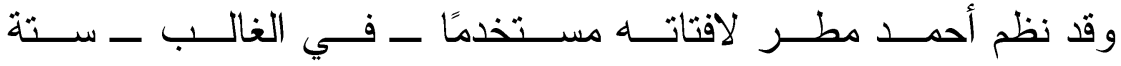

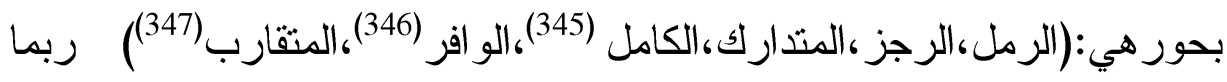

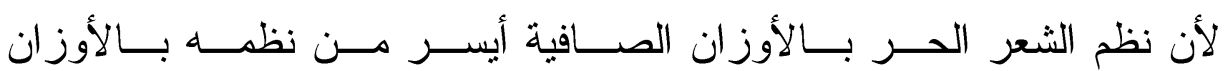

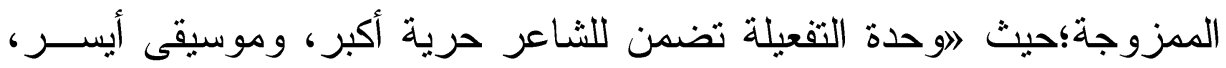

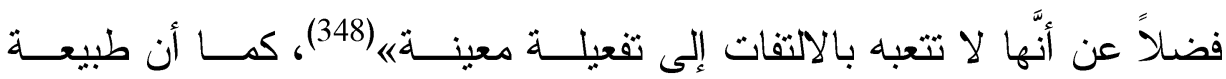
الإبيجز ام تتطلبها. و لن أتوقف طويلا مع نماذج البحور قناعة بأن جوهر الإبيجر ام الموســيقى

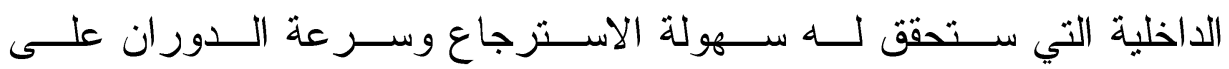
الألسنة،وسأثير فقط إلى نماذج من البحور الأكثر شيوعًا:

[أ] الرمل:

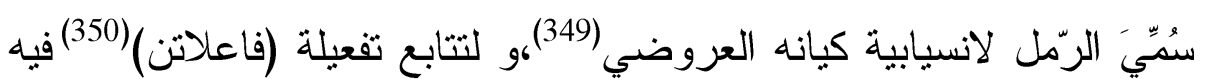

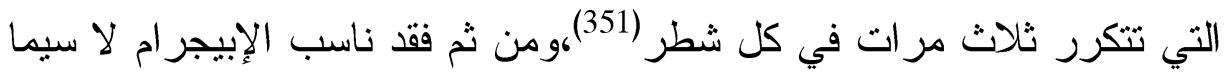

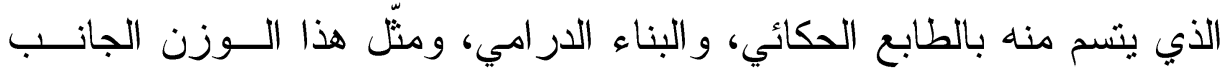


الأعظم من اللافتات، وظهر هذا الوزن بتشكيلتين إحداهما: تامـــة (فَــاعِلاتُنْ)

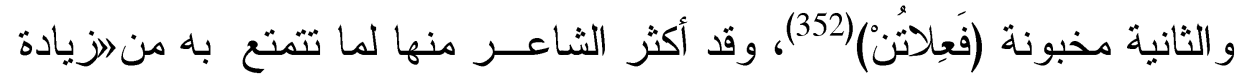

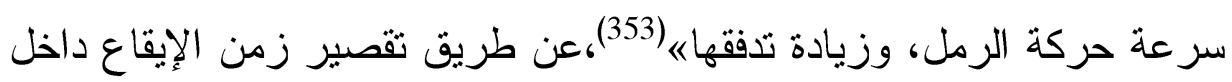

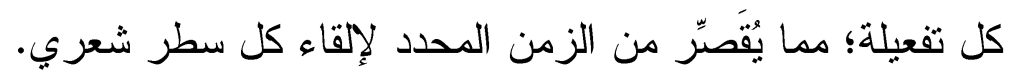

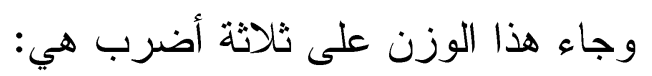

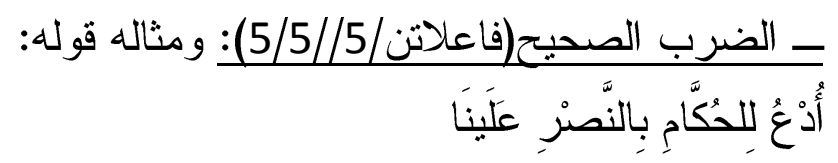
يَا مُوَاطِنْ

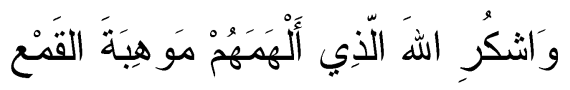
و إِبْدَاعَ الكَمَائنْن

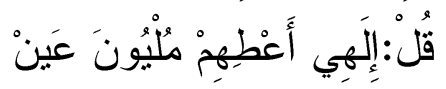

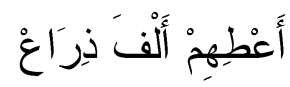

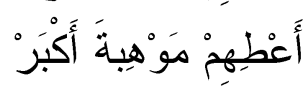

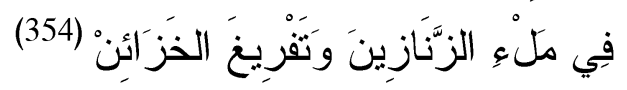

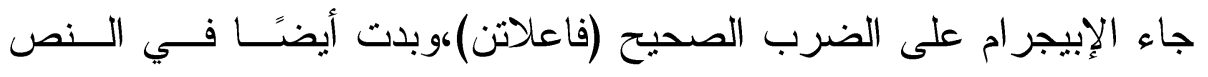

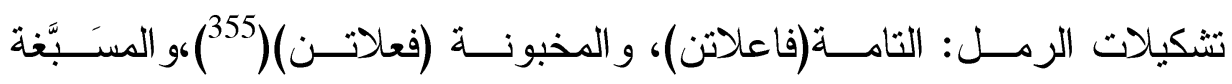

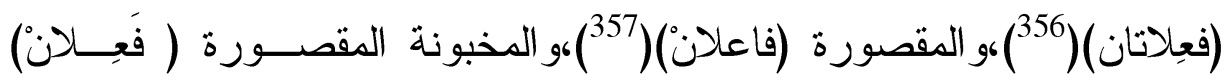

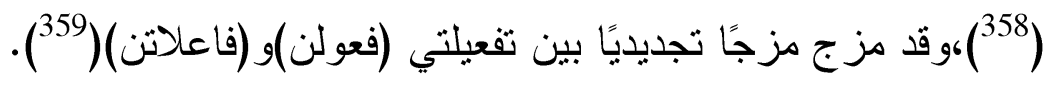

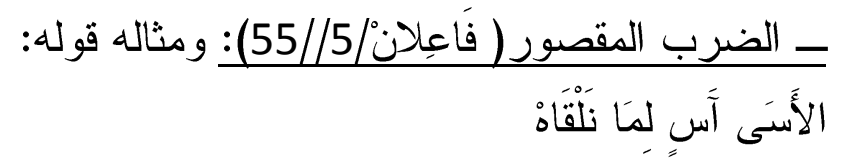

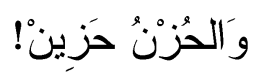

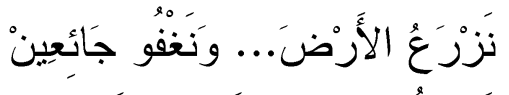

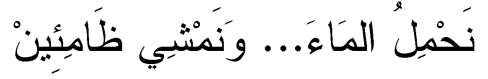
نُخْرِجُ النَّفْْ 


\section{وَلا دِفْءَ وَلَا ضَوْهَ لَنَا}

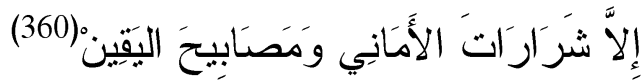

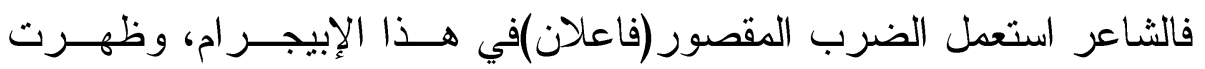

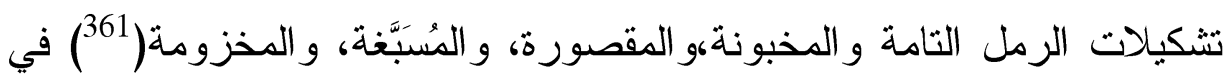

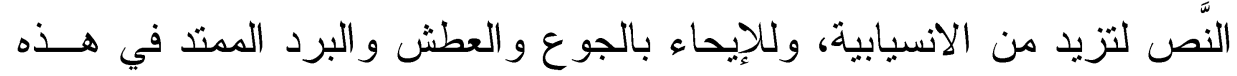
البقعة.

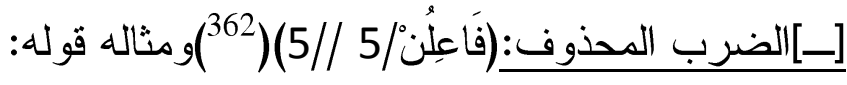

$$
\begin{aligned}
& \text { فِي مَطَارِ أَجْنَبي }
\end{aligned}
$$

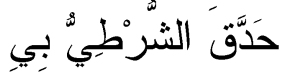

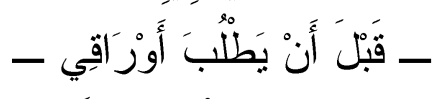

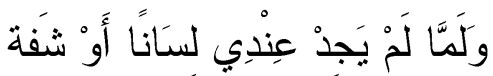

$$
\begin{aligned}
& \text { زم عينيه و أبدى أسفه }
\end{aligned}
$$

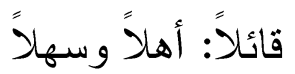

$$
\begin{aligned}
& \text {... يا صديقي العربي!) } \\
& \text { [ب] الرجز: }
\end{aligned}
$$

سُمى رجزًا لاضطر ابه، و لتقارب أجز ائه ولتعرضه للزحافات و العلــلـ(364)

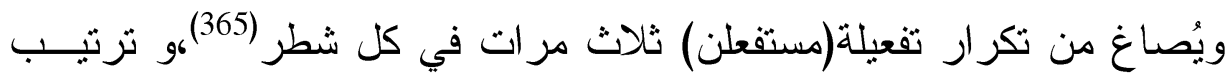

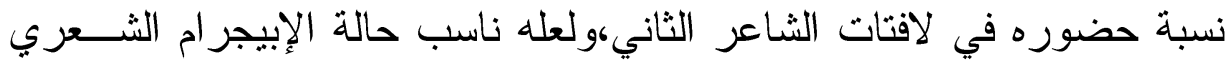

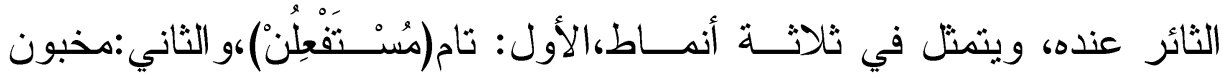

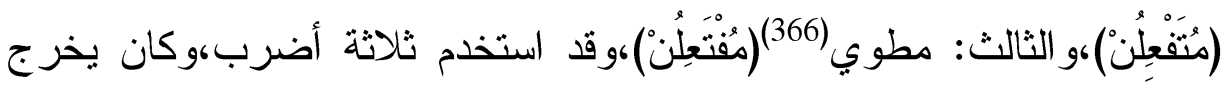
على هذا النظام عن طريق الإتيان بأنماط إيقاعية جديدة قد يُنظر إليها على أنها

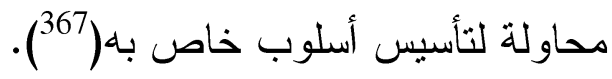




$$
\begin{aligned}
& \text { و عن نماذج للأضرب الثلاثة الأولى فهي: }
\end{aligned}
$$

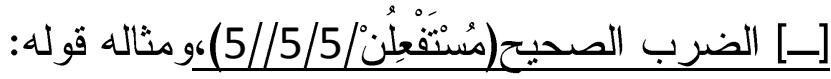

$$
\begin{aligned}
& \text { المرَْْءُ فِي أَوطَانِنَا }
\end{aligned}
$$

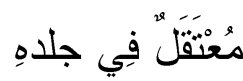

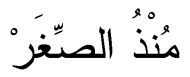

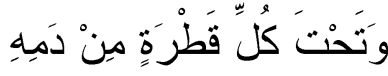

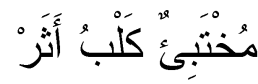

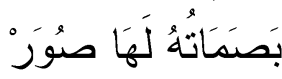

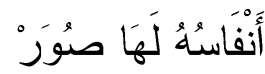

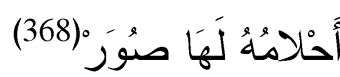

في هذا الإبيجر ام تمثلـــت تشــكيلات الرجز ؛التَّامة،و المقطوعة،ور المطويـــة،

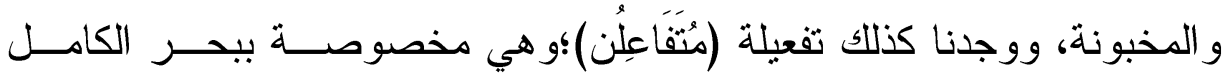

$$
\begin{aligned}
& \text { (369)،وتفعيلة (فَاعِلن)،و هي ليست من تفعيلات الرجز (370). }
\end{aligned}
$$

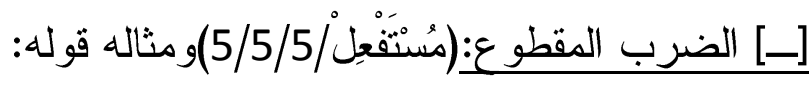

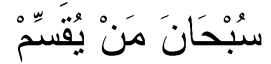

$$
\begin{aligned}
& \text { مَا بَيْنَ الوَرَى أَرْزَ ََقَهُهُ }
\end{aligned}
$$

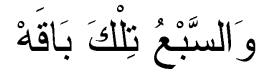

$$
\begin{aligned}
& \text { نَاريَّةُ سَبَّاقَهْ } \\
& \text { وَسَوفَ تَاَتِْي بَاقَهْهُ } \\
& \text { وَسَوفَ تَأْتِي بَاقَهُه. }
\end{aligned}
$$

ويقترب الثاعرفي هذا النَّص من الصياغة النثرية،من خلال جمعه لتشكيلات الرجز في النّص؛ التَّامةهو المقطو عة المخبونة و المقطو عة،و المخبونة بما طوّع لله التو اصل مع شر ائح مجتمعية مختلفة. 


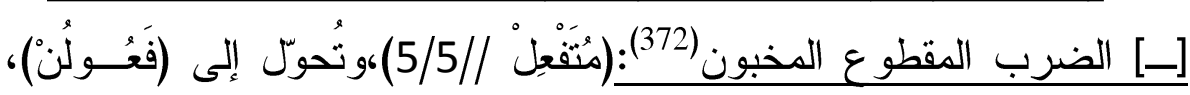
ومثاله قول الثاعر :

رَبَّ اشْفِنِي مِنْ مَرَضَ الكِتَابَهُ

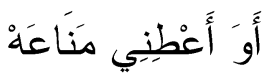

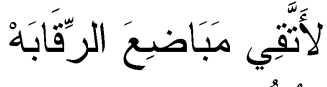

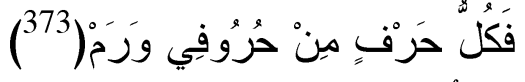

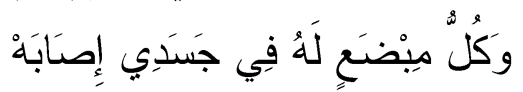

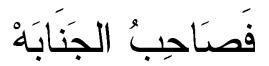

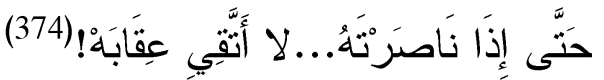

\section{[ج] المتـاريك:}

يتكون هذا الوزن من تكر ار تفعيلة (فَاعِلْن) أربع مرات في كـلـ شـــر كوله

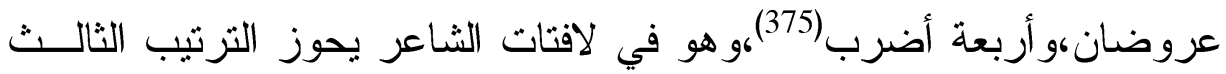
في نسبة الاستخدام، وَتَشَكَّت تفعيلاته في ثلاثة تشكيلات إلأولى التامة (فَاعِلُنْ)

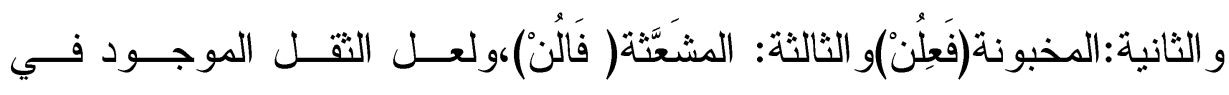
تفعيلة(فاعلن)التامة؛ لاعتمادها السبب الخفيف قبل الوتد المجموع' (376)ربما كان

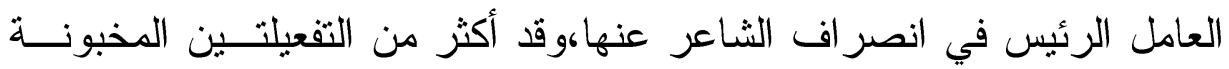

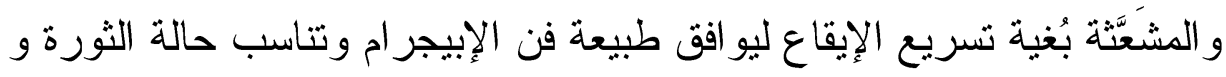
مشاعر ها الانفعالية.

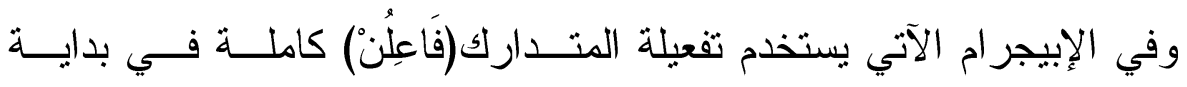

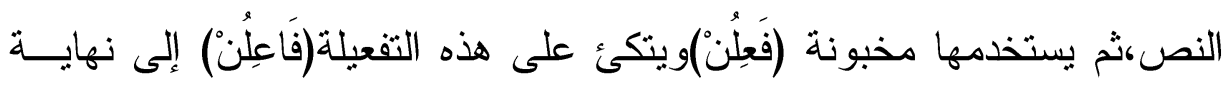

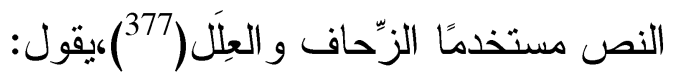

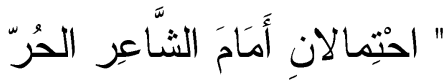

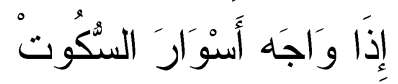
احَنْمَالان: 


$$
\begin{aligned}
& \text { فَإمَّا أَنْ بَمُوت }
\end{aligned}
$$

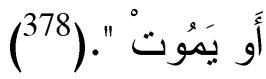

و أحيانًا قد يأتي الإبيجر ام على الوزن المقطوع المشعث (فَعِلْ) كقوله:

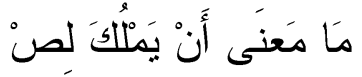

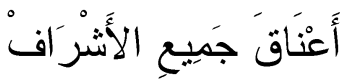

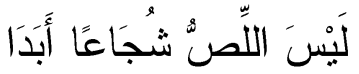

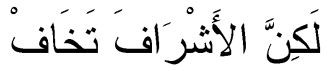

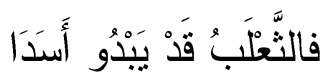

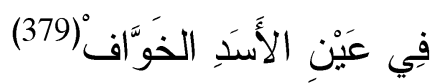

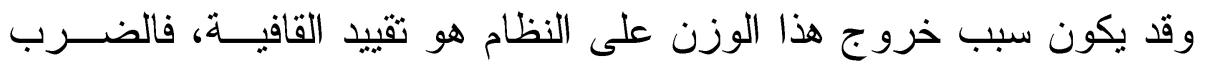

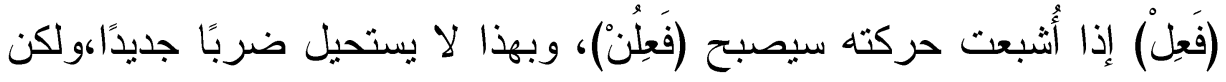
الثاعر سكَّن القافية ليتخلص من قيد الإعر اب ومساءلته.

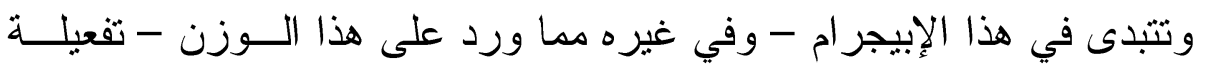

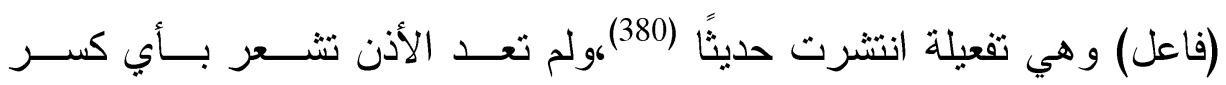

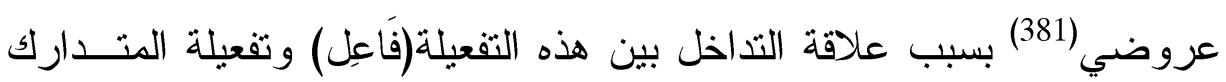
المخبونة (فَعَلُنْ) (382).

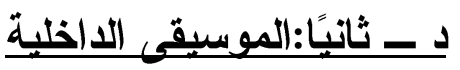

\section{[أ] [لقاقية:}

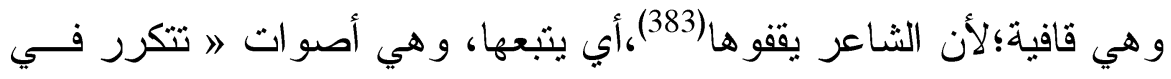

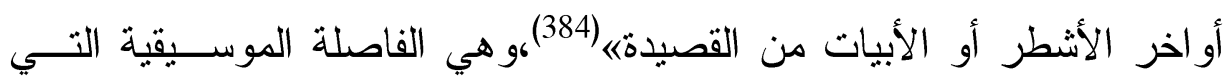
يتوقع السامع ترددها ويستمتع بهذا التردد (385)

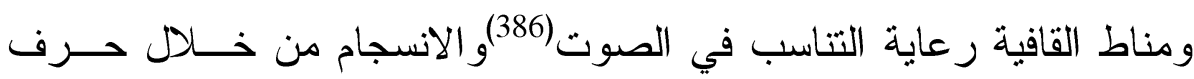

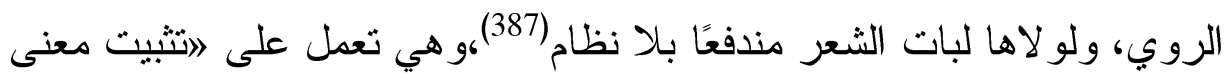
البيث، وتتشأ عنها أيضًا لذة موسيقية خاصةه (388). 
و دَعَتْ ثورةُ الشعر الحر العربي الحديث ثُلَةً من الشعر اء المحـدثين إلــى

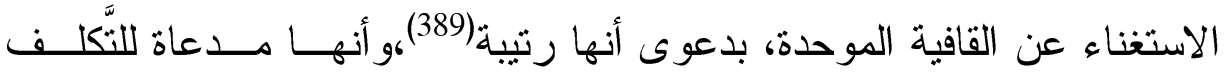

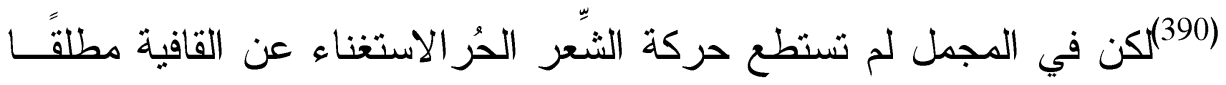

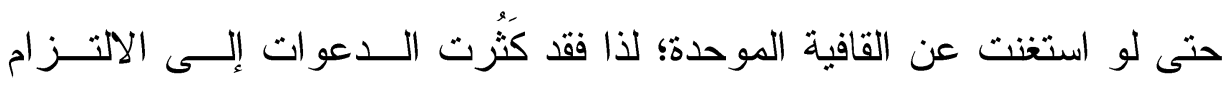

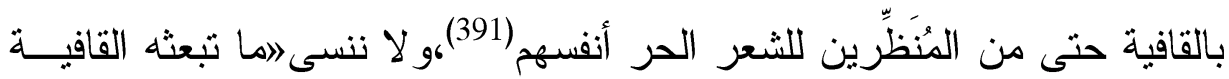

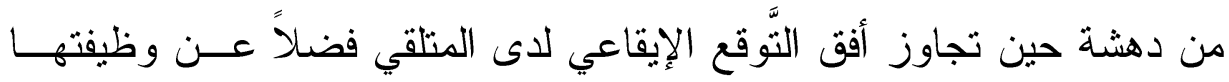

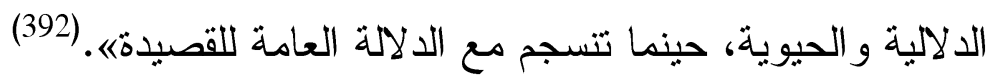

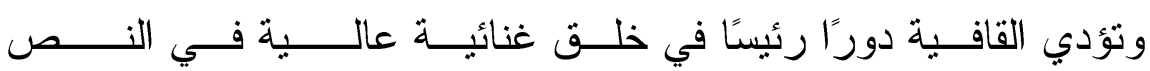

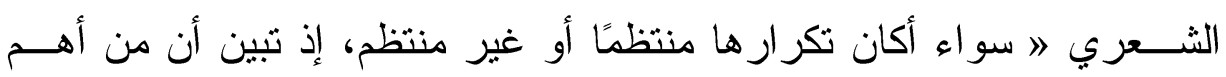

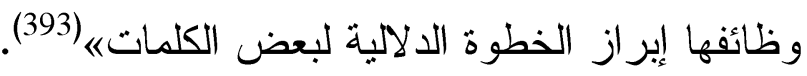

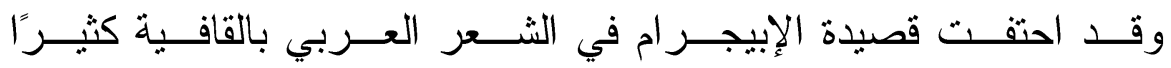

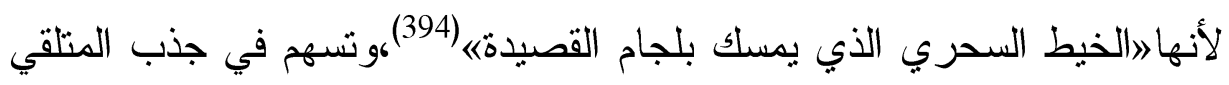
و التأثير فيه؛لأن الإبيجراما تعتدد على المفارقة الإدر اكية، بالإضافة إلى الحِدِّة

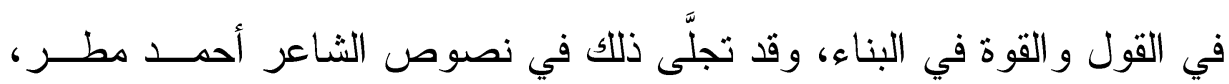

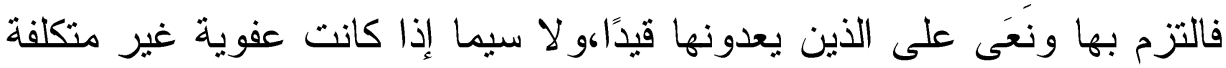

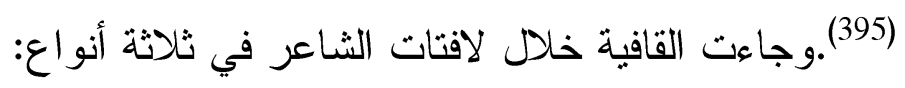

\section{[أ -1] القافية المتجاوبة:}

ويكرر الثاعر في هذا النوع القافية نفسها في نهاية أسطر الإبيجر امهوربما

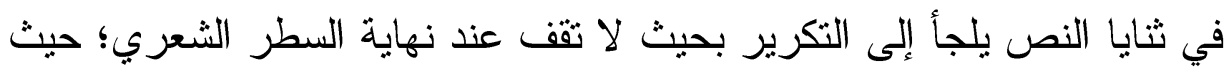

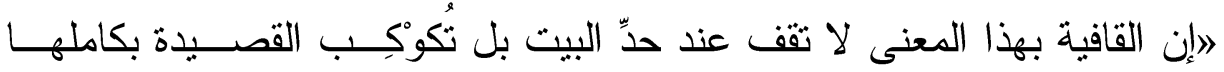

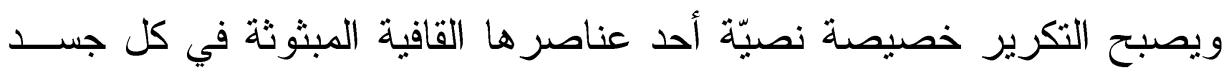
النّص《((396)و هذا مقطع يمتل لهذا النوع قوله:

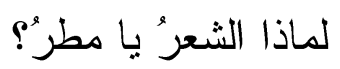

-

doi: 10.12816/0010463 


$$
\begin{aligned}
& \text { لماذا يبزغ القمرُ ؟ } \\
& \text { لماذا يهطل المطرُج }
\end{aligned}
$$

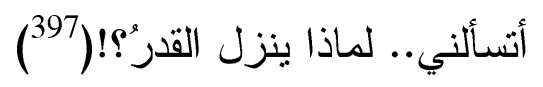

\section{[أ _-2] القافية المزدوجة:}

ويجمع الشاعر قافيتين في الإبيجر ام؛ ليمنح نفسه قدرًا من الحرية في النظم، أنهاء وفي إطالة نَسِّ القصيدة، ومن أمثلتها قوله: بيني وبين قاتلي حكاية طريفه فقبل أن يطعنني وبني حلّفني بالكعبة الشريفه

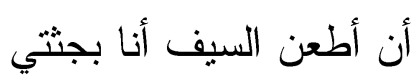
فهو عجوز طاعن وكفه ضعيفه(398) [أ_3] القافية المتعددة:

شاعت هذه النوعية في الإبيجر امات التي تُعَدُ مسترسلة نسبيًا، ويأتي الشاعر الثرأ

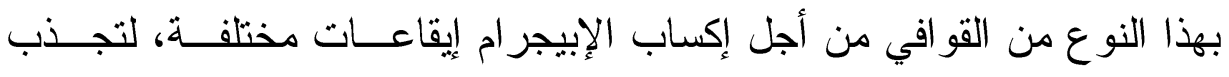

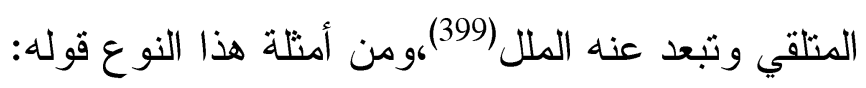

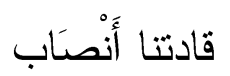

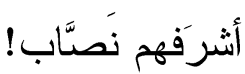

$$
\begin{aligned}
& \text { في حربهر نَصَّاب } \\
& \text { ومالنا نِصنَاب } \\
& \text { لو فرقوا الأسلاب و الرو اتب } \\
& \text { نموت و السلام } \\
& \text { وقادة السلام - عليهم السلام - } \\
& \text { وواجب الو اعظ قول الواجب علب البعام }
\end{aligned}
$$


وو اعظ المز اد يغلب شهرز اد فإن غير الز اد اد (400) بالكذب بيتز اد و الملاحظ على القافية في هذا الإبيجر ام أنها قد تعددت غير مــرة، وكــرر

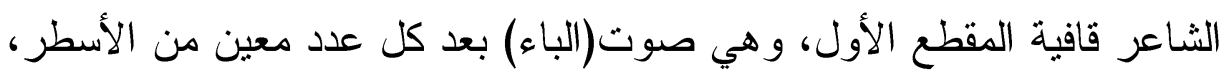

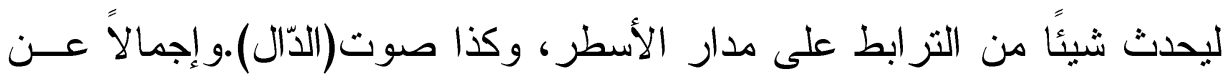
أصوات الرويّ، فقد حرص أحمد مطر على ذكر هذا الصوت في إبيجراماتــهـ كلها التي ضمتها اللافتات.

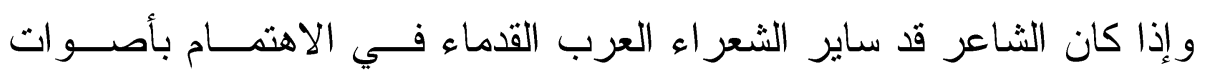

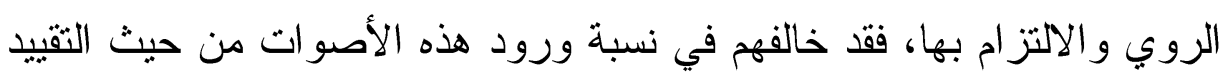

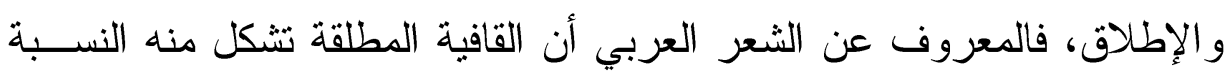

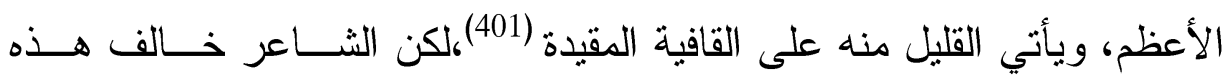

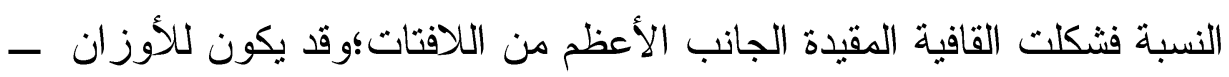

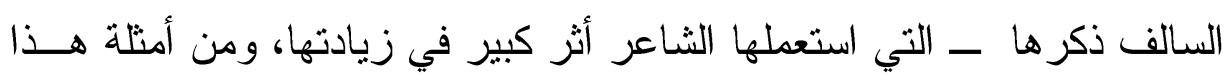

$$
\begin{aligned}
& \text { النوع قوله: } \\
& \text { ساعة الرمل بلاذّ } \\
& \text { لا تحب الاستلابْ } \\
& \text { كلما أفرغها الوقت من الروحْ } \\
& \text { استعادت روحها } \\
& \text {... بالانقلاب! (402) }
\end{aligned}
$$

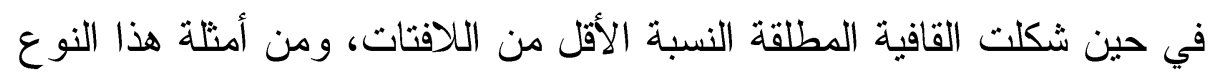
قوله:

و أقداح يعرش فوقها الخدرُ،

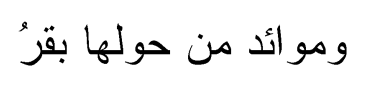

doi: 10.12816/0010463 


\section{ويكونُ مؤتمرُ؛}

هزّي إليك بجذع مؤتمرٍ

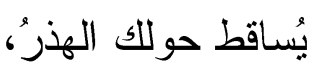

عاش اللهيبُ ويسقطُ المطر׳" (403)

ويتجلّى دور القافية بشكل ملحوظ في الإبيجراما الشعرية عند أحمد مطر

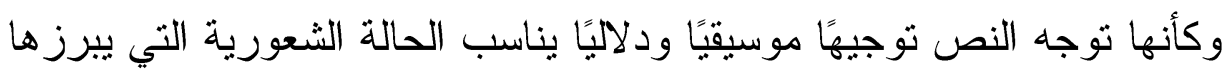

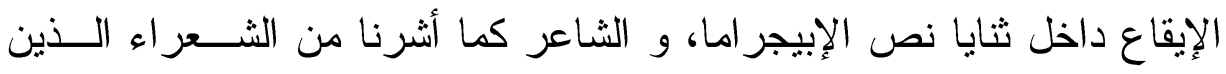
حرصوا على القافية في نصوصهم، فيقول في هذا الإبيجر ام: "حين أطالع اسمه... تنطفئ الأحداق

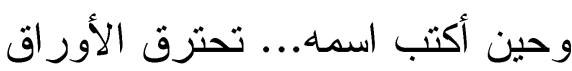

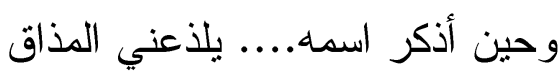
وحين أكتم اسمه... أحس باختناق الدهد

$$
\text { كم هو أمر شاق أن أحمل العراق". }
$$

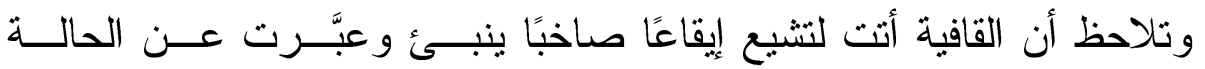

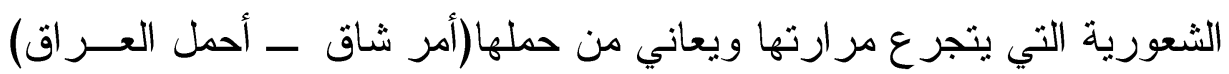

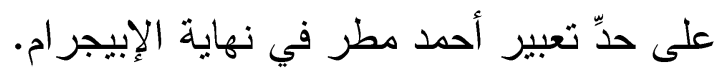

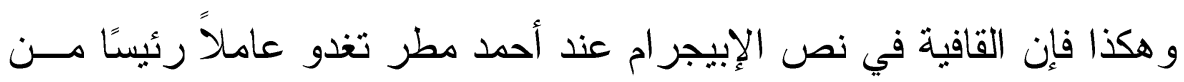

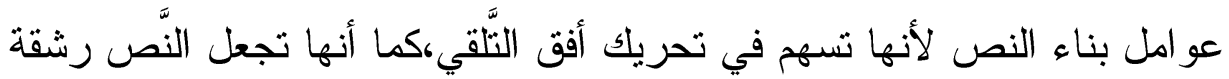
شعرية تنطلق فينتبه القارئ إليها، ومن ثم فإن القافيــة تـــؤدي دورًا موســــقيًا ودلاليًا. 


\section{[ب] التكرار:}

يعني:اتتاوب الألفاظ و إعادتها في سياق التعبير بحيث تشكل نغمًا موســيقيًا

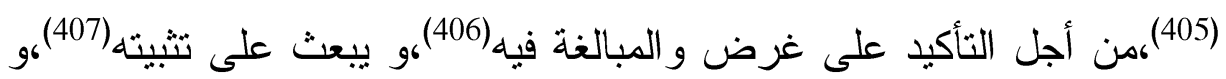

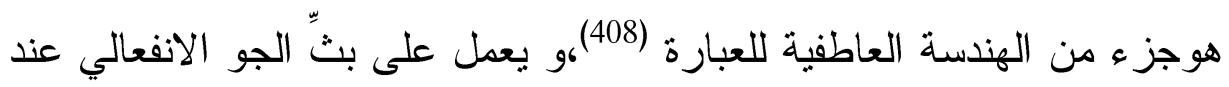
المتلقي. تُتتشر ظاهرة التكرار في النَّص الشعري الحديث فهي لامن أخطر البنَى التي

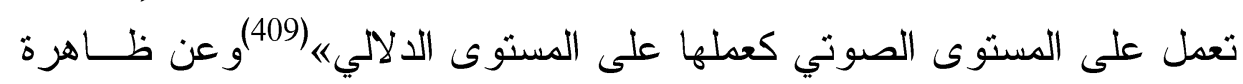
التكر ار في قصيدة الإبيجر ام فهي حاضرة بقوة

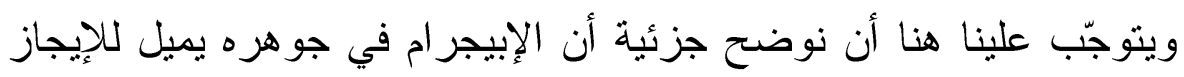

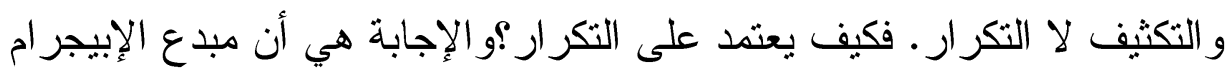

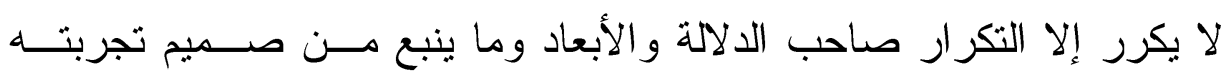

ويثريها، وتكون له القدرة على تحقيق التغيير .4(410) وقد عوّ أحمد مطر بشكل كبير على بنية التكرار في لافتاته نظرًا لما يتمتع

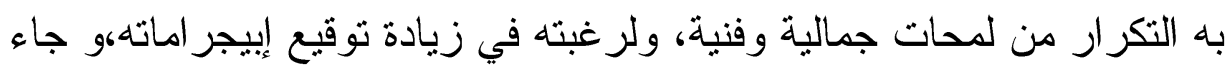
بأنو اع عدة منها:

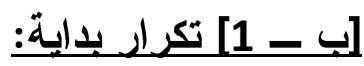

وهو أن يكرر الثاعر اسم أو فعل أو حرف في بداية غالبية أسطر الإبيجرام

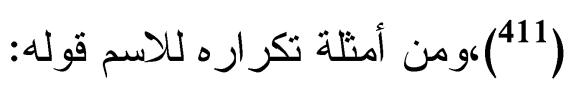
دولة من دولتين دولة مابين بين دولة دولين دولة مر هونة، و العرش دين دولة ليست سوى بئر ونخلة دولة أصغر من عورة نملة دولة تسقط في البحر 


$$
\begin{aligned}
& \text { إذا ما حرّك الحاكم رجله! } \\
& \text { دولة دون رئيس.. } \\
& \text { ورئيس دون دولة!(412) }
\end{aligned}
$$

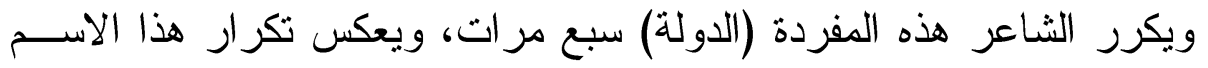

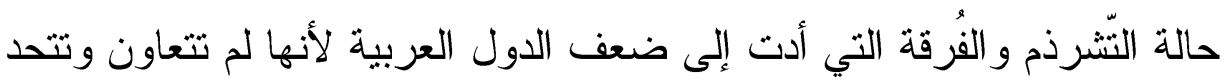

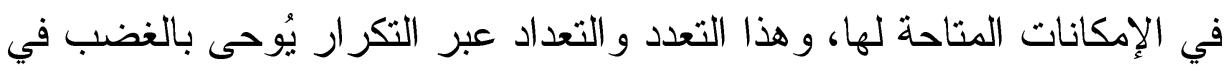
نفس الثاعر حبال هذه الفُرقة.

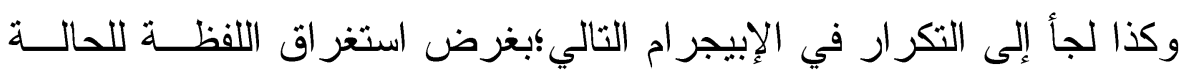

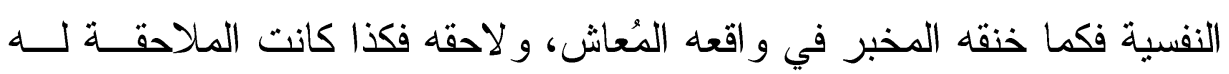

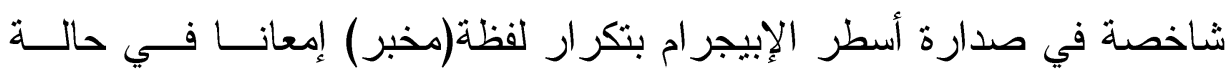
الاختناق و لتعبر عن استغراق المعنى و المبنى الشعري، و تعكس ظلإل اليأس الجاثم جثوم مفردة (مخبر)في مفتتح أسطر الإبيجرام، يقول:

$$
\begin{aligned}
& \text { مخبر يسكن جنبي } \\
& \text { مخبر يلهو بجيبي } \\
& \text { مخبر يفحص عقلي } \\
& \text { مخبر ينبش قلبي } \\
& \text { مخبر يدرس جلدي } \\
& \text { مخبر يقر أ ثوبي } \\
& \text { مخبر يزر ع خوفي }
\end{aligned}
$$

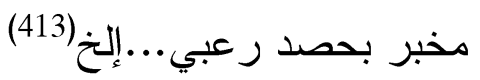

وقد يُكرر الثاعر الفعل في بداية الأسطر محاو لاً الإفادة من قابلية الأفعال في ري

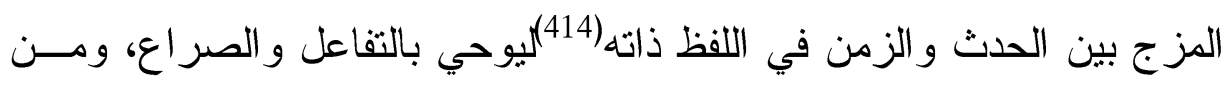
أمتلة تكرار الفعل في البداية، قوله: كبرت دائرة المأساة 


$$
\begin{aligned}
& \text { كبرت دائرة المأساة } \\
& \text { كبرت... } \\
& \text { كبرت... } \\
& \text { حتى ضاقت! } \\
& \text { كيف أحرر ذاتي (415). }
\end{aligned}
$$

فكرر الثاعر الفعل لتهويل الحدث(المأساة)والتي حذفها الثشاعر في الثطرين

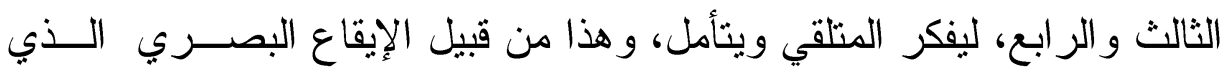

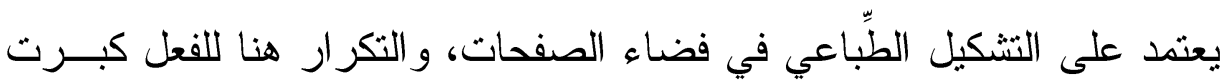

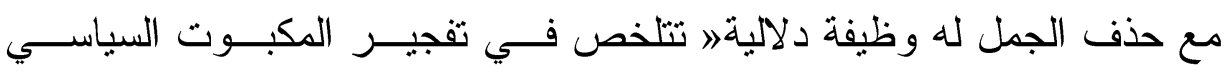

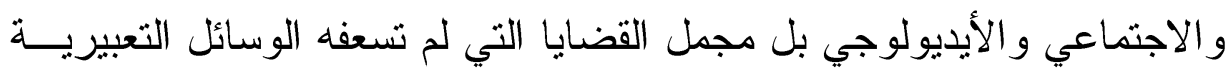

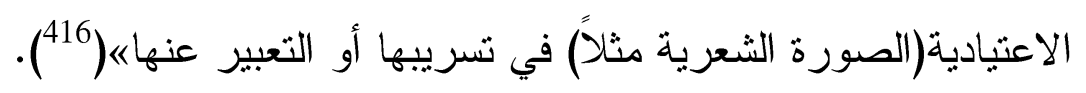

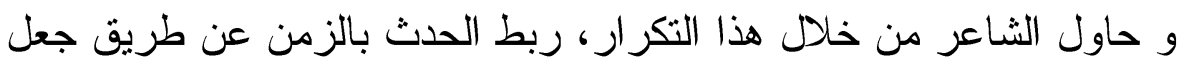

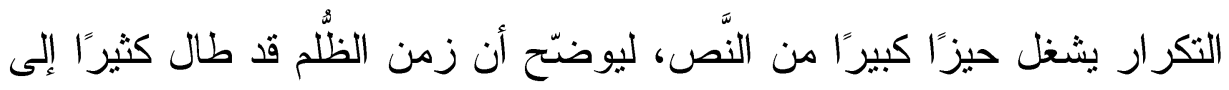

$$
\text { درجة أن الأرض العربية قد ضاقت على أهلها. }
$$

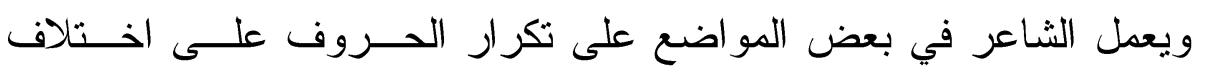

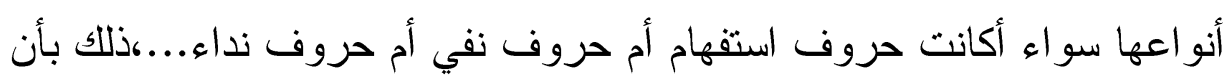

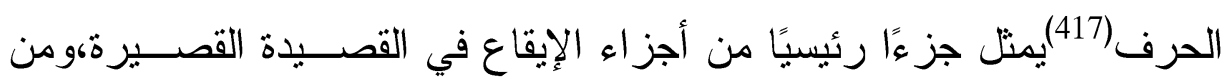

$$
\begin{aligned}
& \text { أمثلة هذا النوع قوله: } \\
& \text { وَصَفَو الي حاكمًا } \\
& \text { لم يقترف، منذ زمان } \\
& \text { فتنة أو مذبحة } \\
& \text { لم يكذب! } \\
& \text { لم يخن لم بحن } \\
& \text { لم يطلق النار على من ذمه! }
\end{aligned}
$$


لم ينشر المال على من مدحه! - إ

زرت مأو اه البسبط البارحة

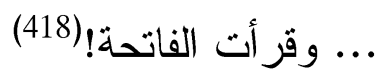

يكرر الثاعر حرف النفي والجزم (لم)عشرة مرات،لنفي الصفات السيئة عن

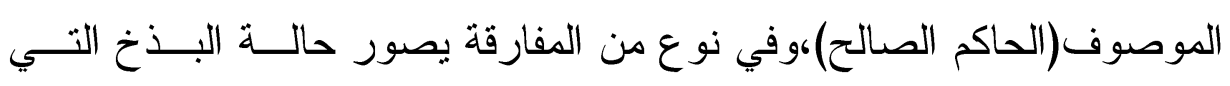

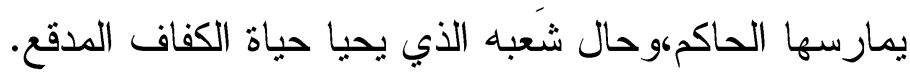

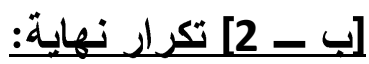

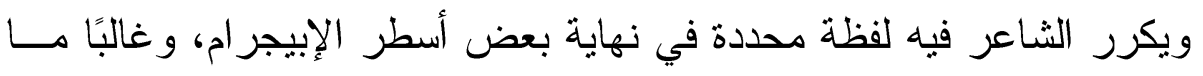

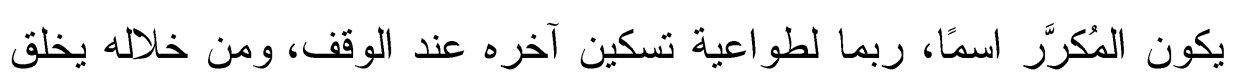

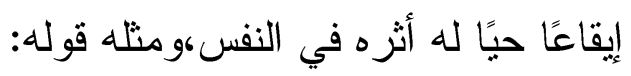

$$
\begin{aligned}
& \text { يا هاربًا من عدم } \\
& \text { ور اكضًا في عدم هن } \\
& \text { و ولاجئًا إلى عدم.. (419) }
\end{aligned}
$$

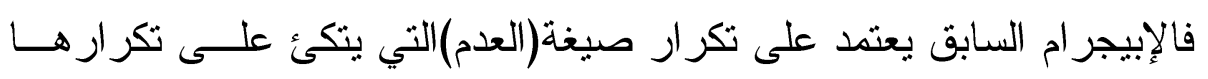

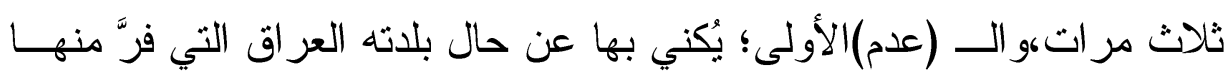

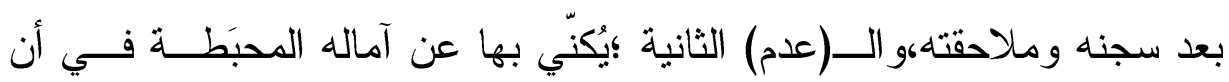

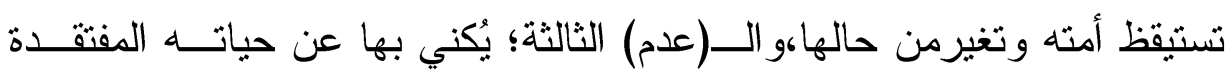

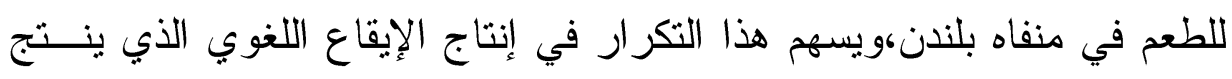
عنه إيقاع داخلي مألوف يلفت النظر و الانتباه إلى مضمون فكرنه الثناه الثعرية.

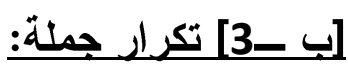

وفي هذا النمط يكرر الثاعر جملة محددة داخل النصهبهدف توجيه القصيدة

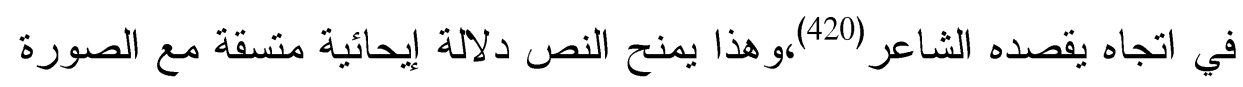

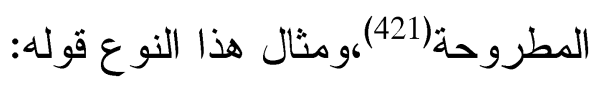




$$
\begin{aligned}
& \text { لا.. لن تموت أمتي } \\
& \text { مهما اكتوت بالنار و الحديد } \\
& \text { لا.. لن تموت أمتي } \\
& \text { مهما ادّعى المخدو ع و البليد } \\
& \text { لا.. لن تموت أمني } \\
& \text { كيف تموت؟ } \\
& \text { من رأى من قبل هذا ميتًا } \\
& \text { يموت من جديد ؟!(422) }
\end{aligned}
$$

فالثاعر في هذا النص يبث إلى المتلقي للوهلة الأولى فكرة تحمسه و إيمانـــه

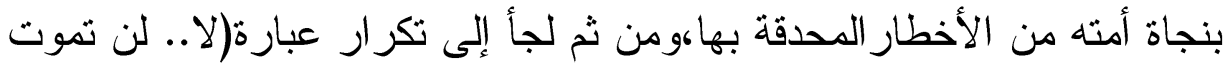

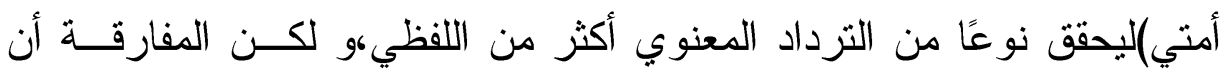

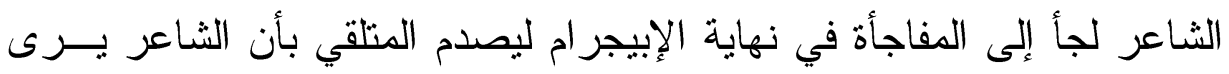

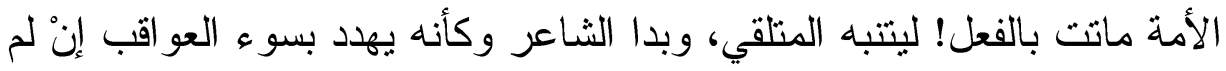
تتفض الأمة الاستسلام عن نفسها!. [ج] التَّجنبس: ويُدرج ضمن صنوف التكرار،و يفيد تقوية النغم وتتاسقه في البيث، ويعضد

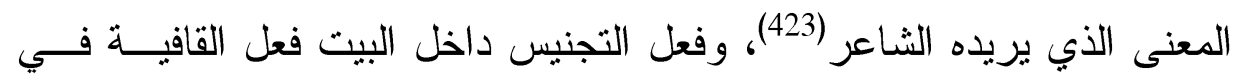

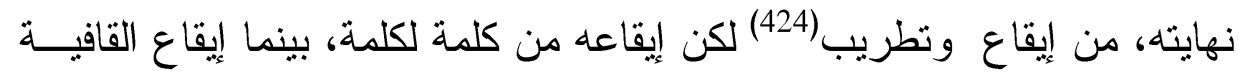

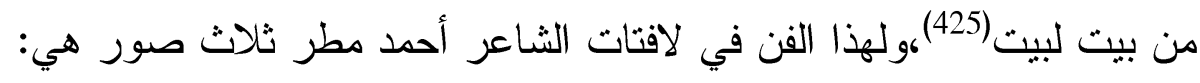

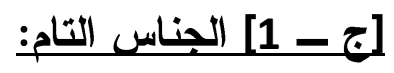

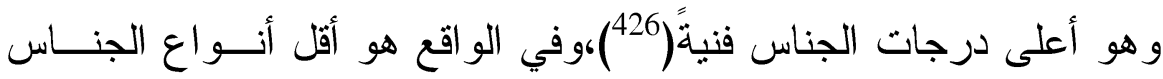
ورودًا لدى الشاعر بسبب صعوبة مر امه من جانب، ولكون الإكثار منه قد يسم

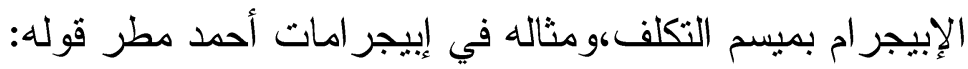

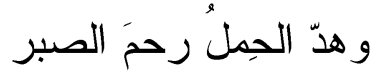




$$
\begin{aligned}
& \text { حتى لم يطق صبرا } \\
& \text { فأنجب صبرنا صبر !! } \\
& \text { وعبد الذات } \\
& \text { لم يرجع لنا من أرضنا شبر ا } \\
& \text { فسبحان الذي أسرى } \\
& \text { بعبد الذات }
\end{aligned}
$$

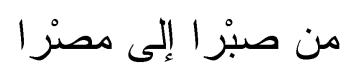

وما أسرى به للضفة الأخرى(427).

فنجد الثاعر قد جانس بين لفظة صبرا الأولى:التي قصد بها"حبس النفس عن

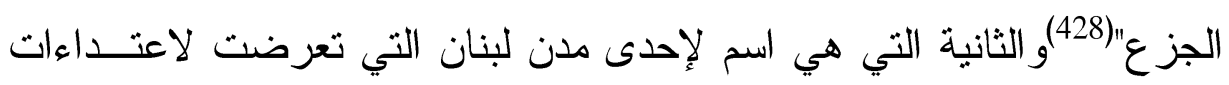
إسر ائيل.

\section{[ج - 2] الجناس الناقص:}

و هذا النوع من الجناس يحقق للثاعر إنجازًا إيقاعيًا يمتع المتلقي ومثاله

$$
\begin{aligned}
& \text { عند الثاعر أحمد مطر قوله: } \\
& \text { أبلادي هكذا؟ } \\
& \text { كلا.. فر اعيها مُريع. } \\
& \text { ومر اعيها نجيع. (429) }
\end{aligned}
$$

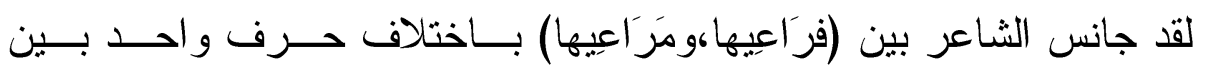

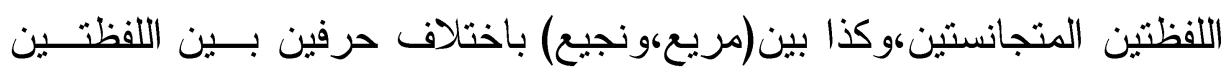

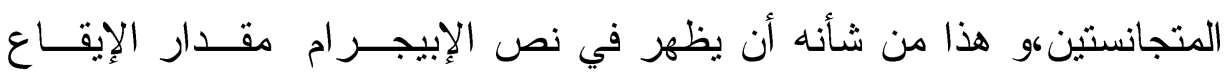

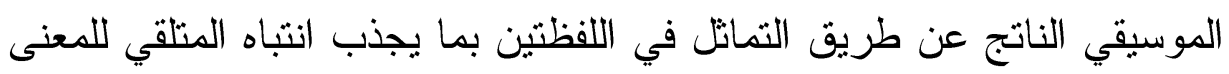
الذي يبتغيه الثاعر. 


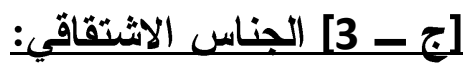

و تتلاقى اللفظتان فيه في بعض حروفهما الأصلية، وفي أصل المعنى الــذي الــي نشأنا عنه(430)وه هذا من أكثر الأنواع شيوعًا في اللافتات، ويمنح إيقاعًا شعريًا

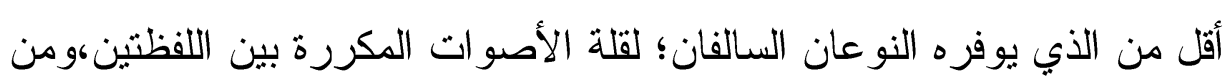
أمثلته قوله:

$$
\text { فر اشة هامت بضو هُ شمعة }
$$$$
\text { فحلقت تغازل الضرام }
$$$$
\text { قالت لها الأنسام }
$$

(قبلك كم هائمة.... أودى بها مالهام الهيام!

$$
\text { خذي بدي }
$$

لن تجدي سوى الردى في دورة الختام)

$$
\text { لم تسمع الكلام. }
$$

ثم هوت (431).

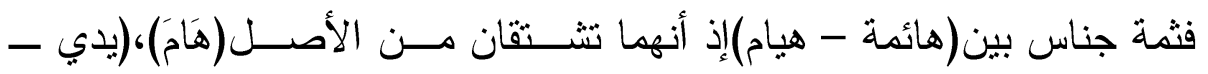

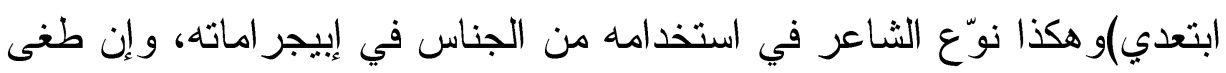

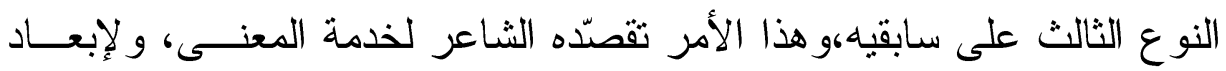
أشعاره عن سَتَ التَّنَع.

[ـ] التوازي ودوره في تثثكيل نص الإبيجر ام:

التوازي من المفاهيم التي برزت في العصر الحديثهو ذللك على الرَّفم مــن

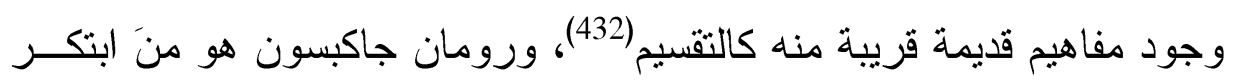
هذا المفهوم - في الدراسات الحديثة - وجعله المبدأ المؤسس للوظيفة الشعرية للغة(433). 


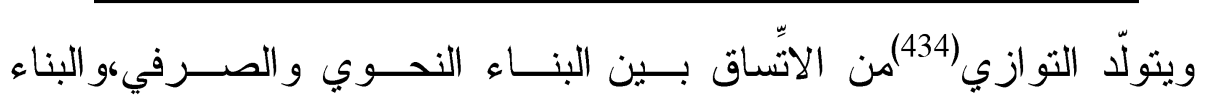

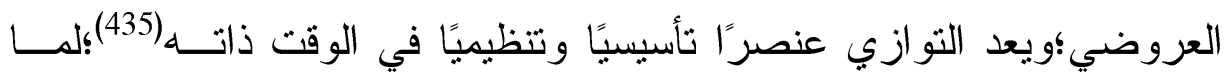

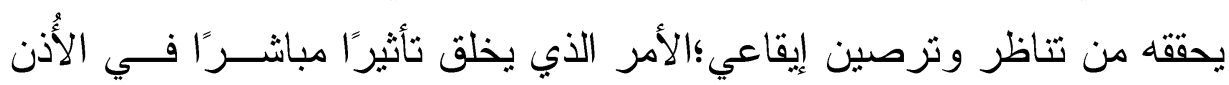

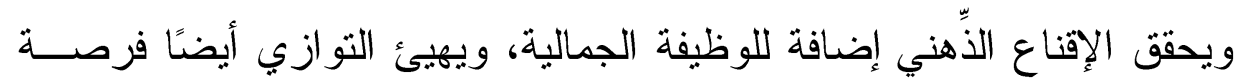

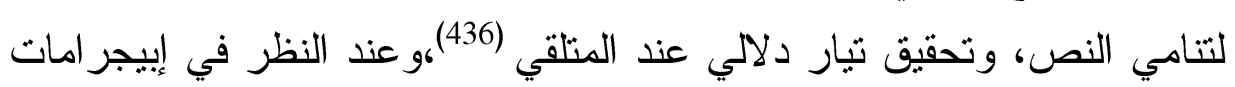

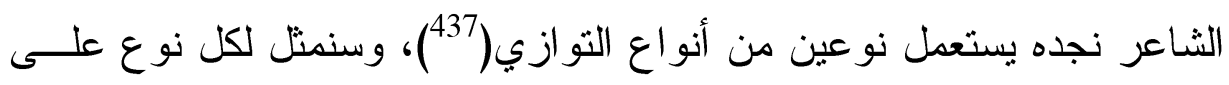

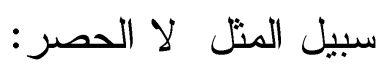

\section{[دـ د ـ1] التوازي النحوي و الصرفي:}

وفيه تأتي الأسطر المتوالية، طبق صورة نحوية وصرفية موحدة،ومن أمثلة هذا النوع قوله: وخُطى الشرطة من خلف خطانا تركض! يُعدم المنتفِضُ وخُى

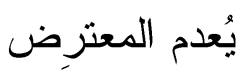

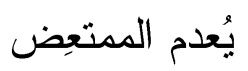
يُعدم الكاتب و القارئُ و الناطق و السامع

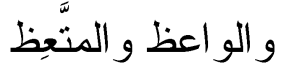
حسنًا يا أيها الحكام المنظف لا تمتعضو ا. حسناً. أنتم ضحايانا ونحن المجرم المفترض!(438)

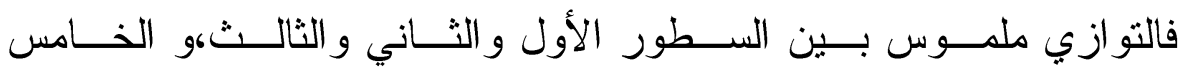

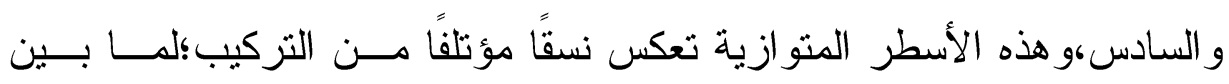

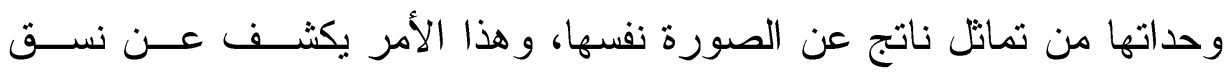


عروضي موحد بين المتو اليات المتوازية،و هذا من شأنه أن يؤطر الفكرة التي

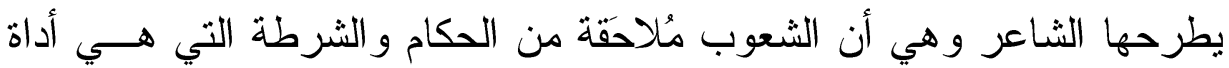

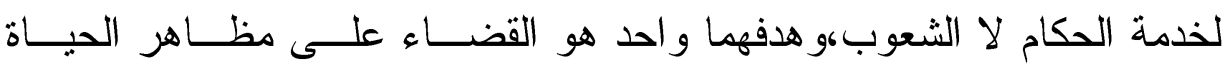

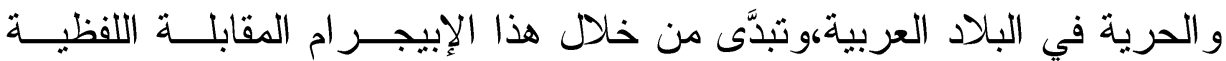
و الفكرية بين الجاني و المجني عليه بما يحدث المفارقة.

\section{[دـ د ـ 2] التوازي المتقابل:}

ويعتمد هذا النوع من التوازي على تحقيق تقابل دلالي بين عنصــرين فــي

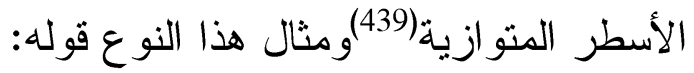

إن في النطق الندامه النه

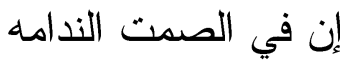

أنت في الحالتين مشبوه فتب من جنحة العيش كإنسان و عش مثل النعامه (440).

فنجد أمرين(النطق والصمت) يشغلان المرتبة نفسها في التركيب ويحقةــان

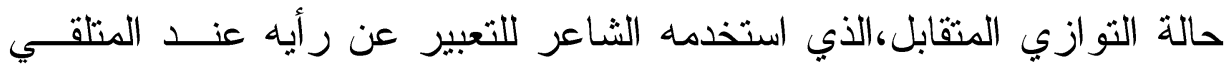

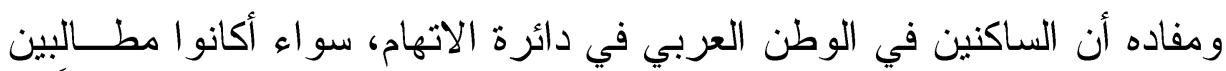

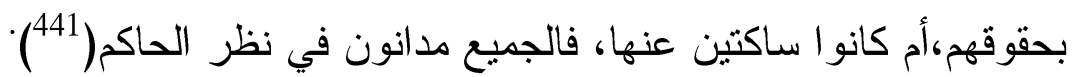

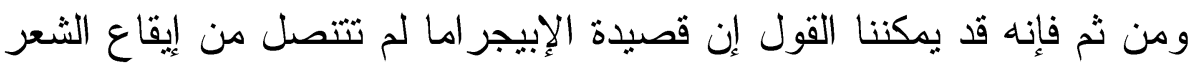

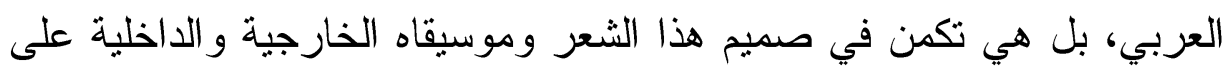

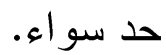




\section{نتائج الار اسة}

اهنمت هذه الدر اسة بعدة قضايا ؛ منها:

ـ الثاعر أحمد مطر عراقي الموطن عربي الهوى، وحيد الغرض؛ إذ قصر

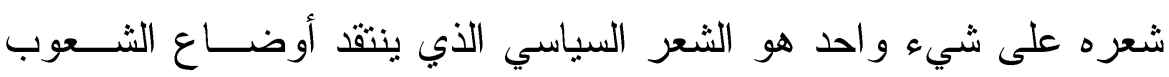
العربية بغرض استتهاض الأمة ـ في وجهة نظره ــ لترنشف أمته العربية وبلده العراق من فيض الحُريّة. ــ مارس فنّه الشعري من خلال قصيدة الإبيجر ام، ومن ثم تطرّت الدراســة

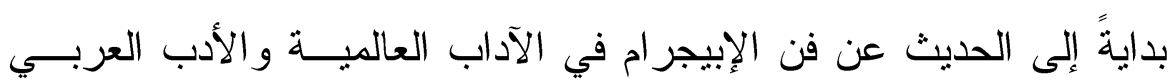
قديمها وحديثها بصفة عامة.

ــ اعتمدت موضوعات الإبيجر ام عنده على موضوعات الهجاء و الانتقــادات السياسية و التّهكم و السُخرية التي تموج بالمفارقة، وقصيدة الإبيجرام غالبًا.

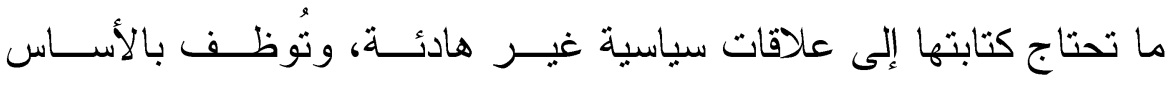
للخصومة مع المُعارضين.

ــ قو ام الفئات التي تتاولها هذا الفن لديه الأشخاص أو الفئـات الاجتماعيــة المحددَّة، وكذلك الموضوعات بطبيعة الحال، ومن ثم أصبح هذا الفن مُهمًا من حيث هو سلاح في الخصومة أو النّزاع السياسي ووظفه أيضًا للتسديد نحو شخصيات و هيئات بعينها في البلدان العربية. ـ لا يتعين أن يكون الإبيجر ام أبياتًا أو سطورًا شعرية مستقلة من البداية، بل

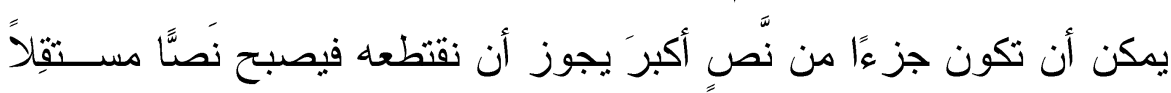
حينئذ.

- يتّم هذا الشَّكل الأدبي لديه بالقِصرَ ،ويحسب الاقتضاب فضيلةً ومطلبًا لهذا

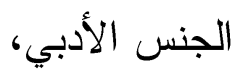
ولمّا كان هَدَفَ هذه الدراسة قصيدة الإبيجر ام عنده؛ فقد توسل البحث إلـىى ذللك بتتبع البنَى المختلفة، وخرجت بعدد من النتائج منها: 


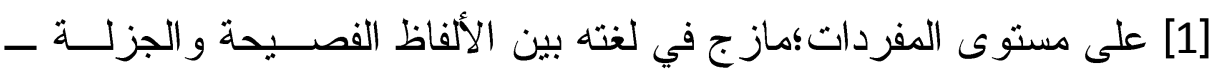

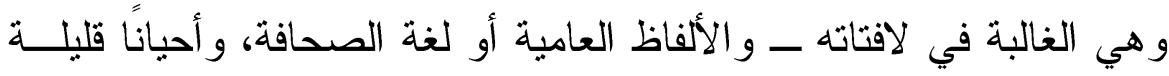

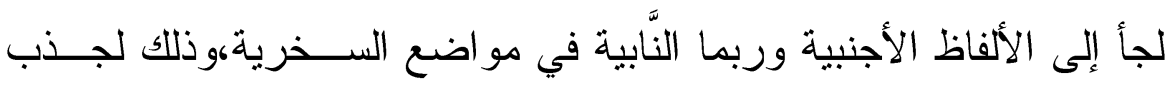

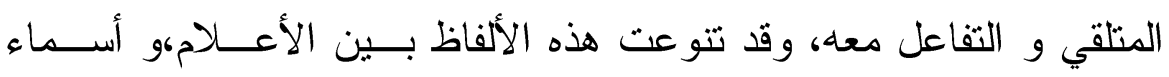

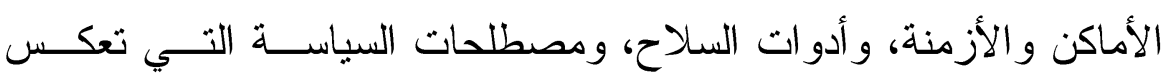

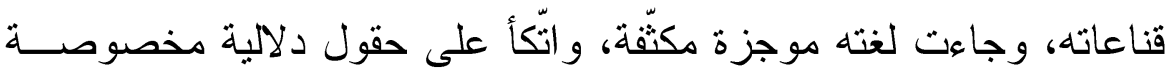
مثل (و الموت و الحزن و الزمن و المكان).

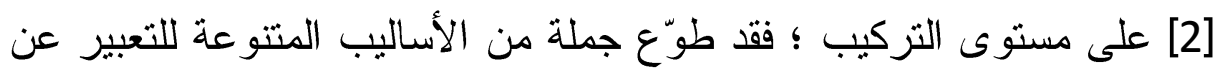

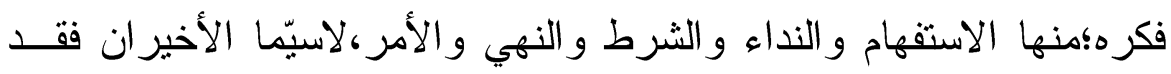

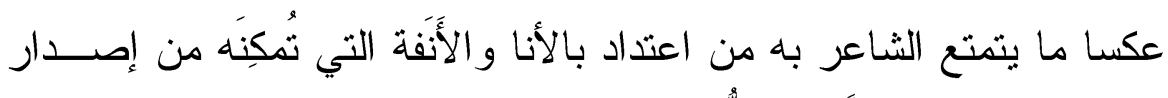

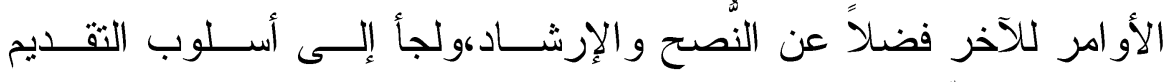

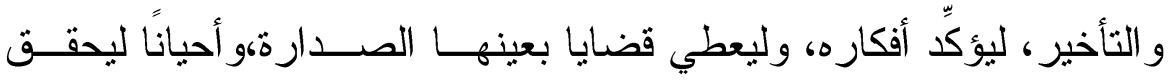

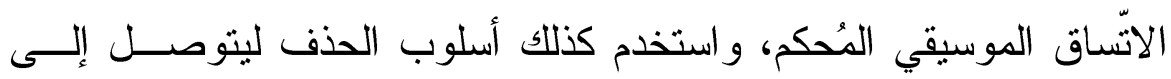
الإيجاز و التكثيف المنتظر في قصيدة الإبيجر ام، وليفتح مجــالاً للأبعـاد

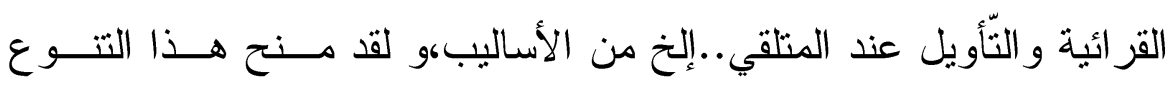

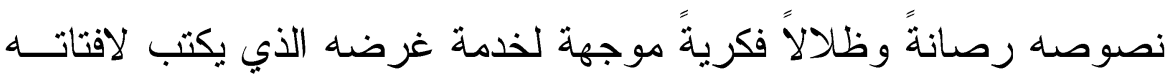
من أجله، وكان للإيجاز و التكثيف اللذين هما من سمت الإبيجرام أثرهما في

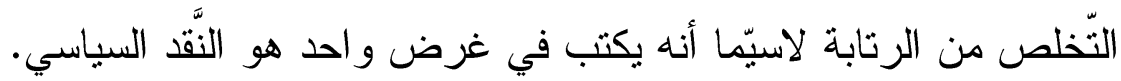
[3]على مستوى بنية الإيقاع الخارجي ؛ فقد استخدم ما يناسب قصيدة الإبيجرام

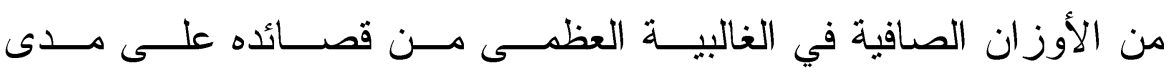

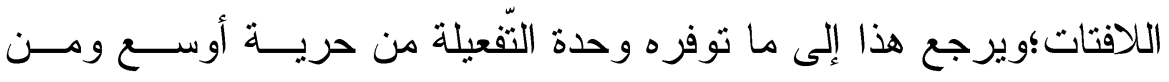

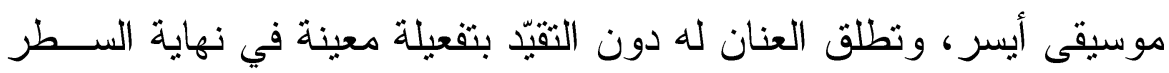

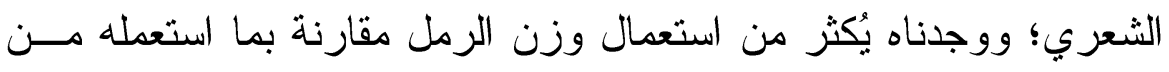

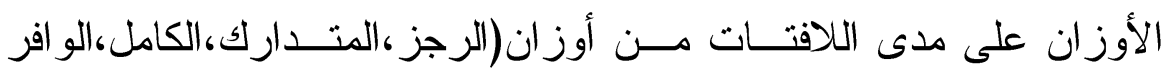
doi: $10.12816 / 0010463$ 
البسيط..)،وقد يُعزى هذا الاختيار إلى ما تحققه هذه الصياغة في هذا الوزن من انسيابية و استرسال في السرد.

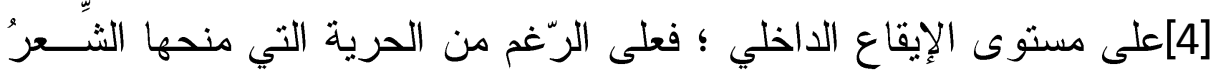

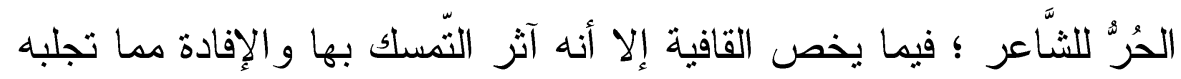

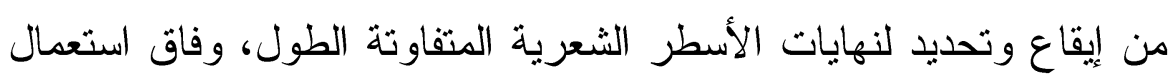
الثاعر للقافية المقيدة استعماله للقافية المطلقة وأتى عليها.

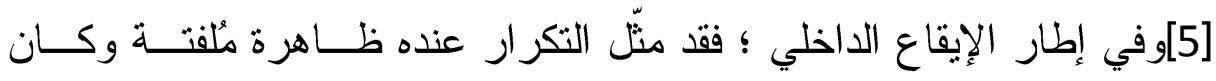

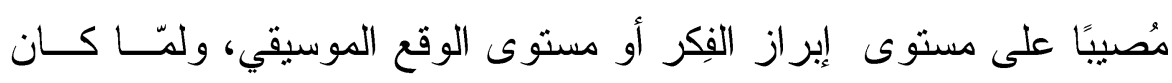

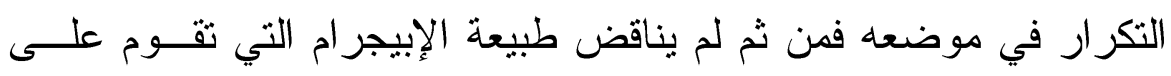

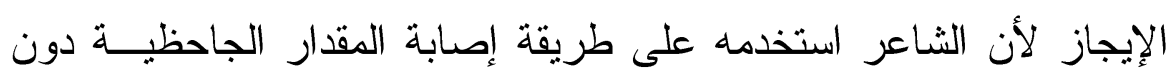
إفر اط في استخدامه أو تفريط فيما يحققه من جمالية.

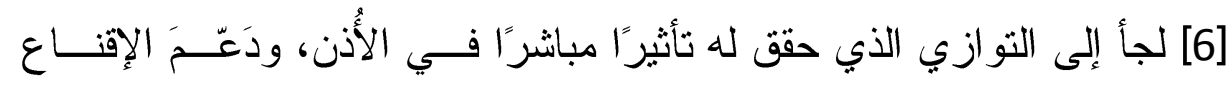

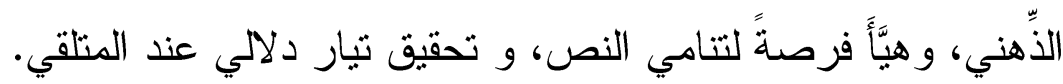

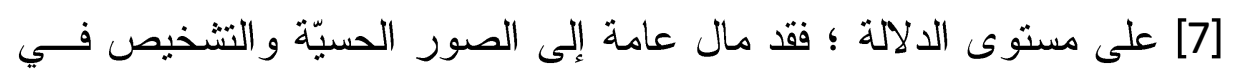

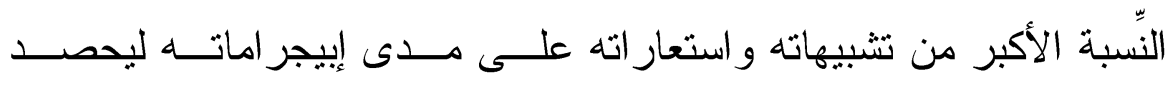

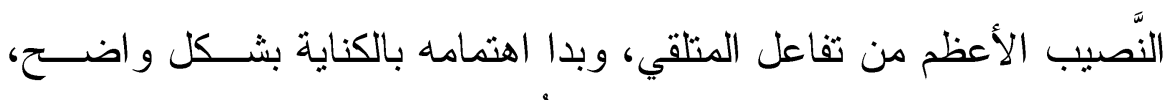

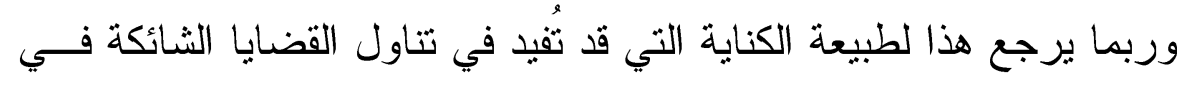
أمته دون أن نوقع به في قبضة السئلطات في أحيان كثيرة.

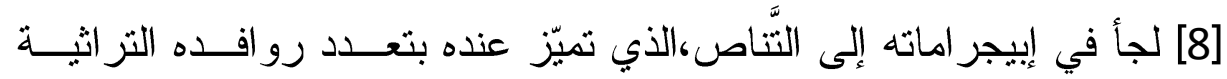

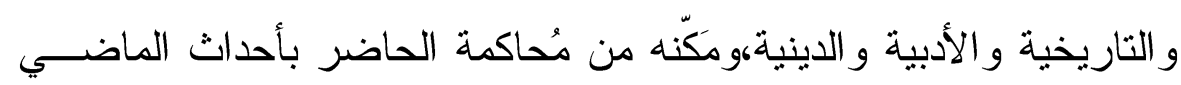

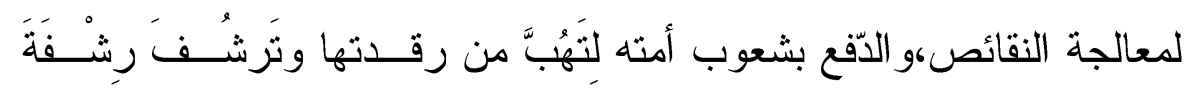

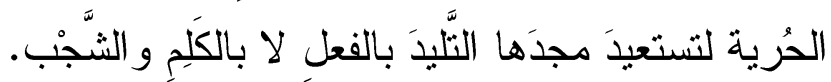

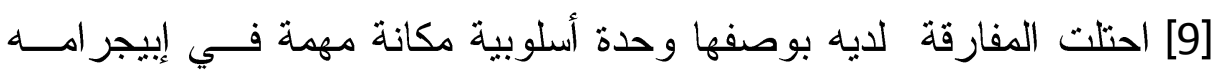

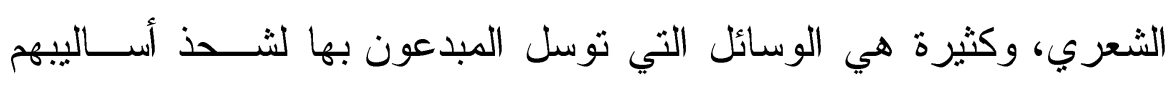


وحشد المعاني فيها، ومن بين تلك الوسائل الفنبة اعتماد المفارقـــة أســلوبًا

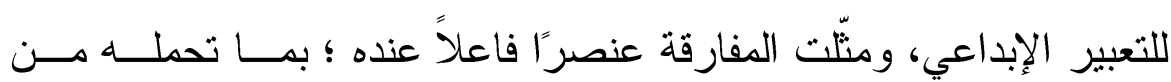

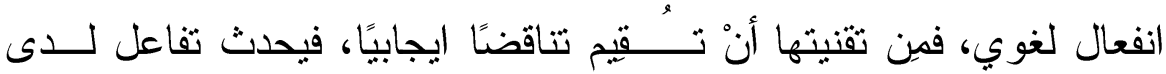

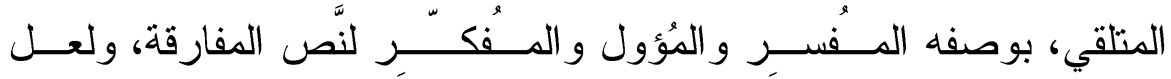

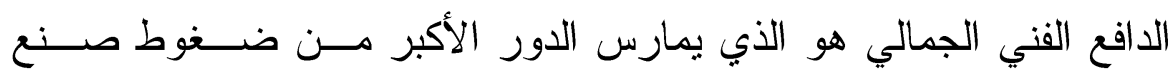

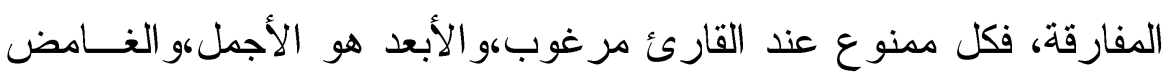

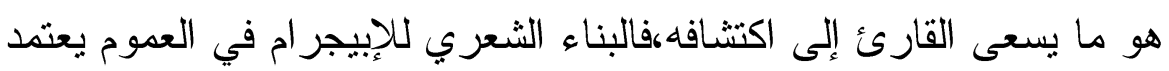
بشكل جوهري على بناء المفارقة.

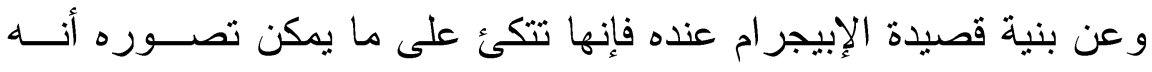

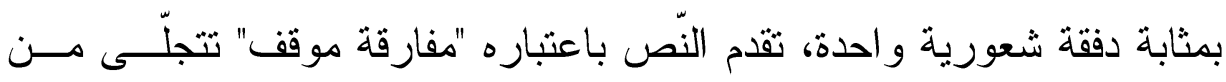

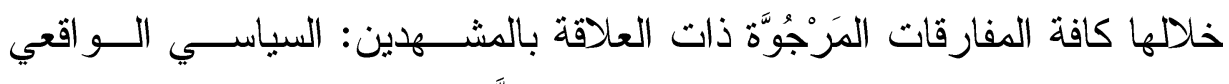
و التاريخي الممند، و إذا كانت القضية كذلك، فالنَّص يتحول عند مطر إلى كثف التف

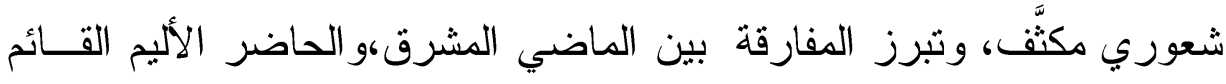

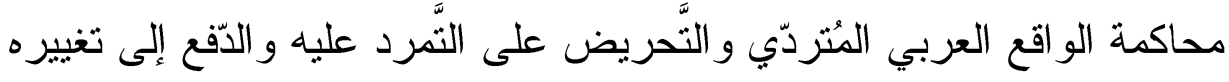

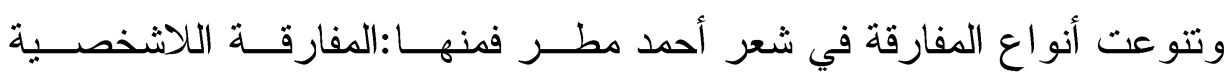
ومفارقة الاستخفاف بالذات،مفارقة الفجاجة، و المفارقة الدر امية.

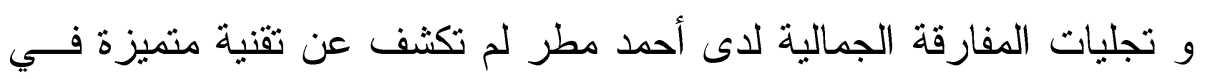
عرض رؤيته الشعرية الفنية فحسب بل كشفت- من خلال التكثيف الــدلالي -

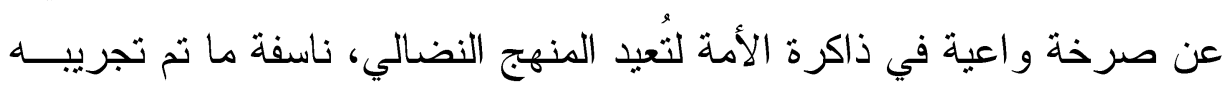

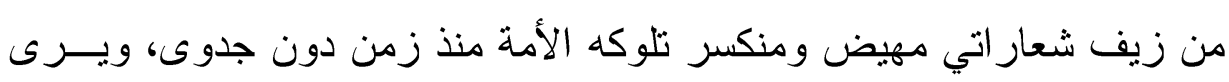

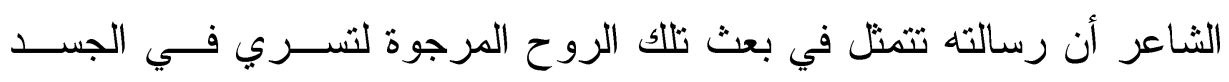
الظمآن، فيتحقق النصر ، وتتم العودة.

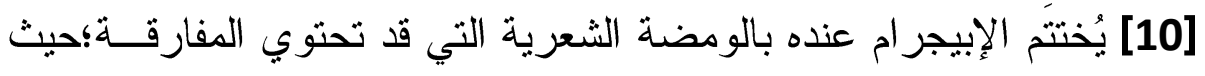

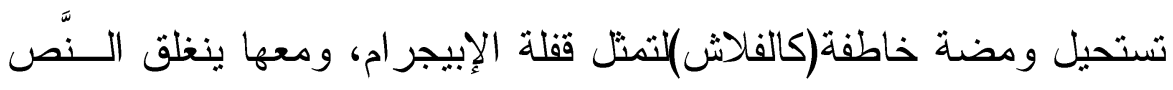
doi: $10.12816 / 0010463$ 
انغلاقًا رائعًا ومحققًا في الوقت نفسه انفتاحًا ثرًا للنقاش و التَّدر ،أو قل مُنبهًا

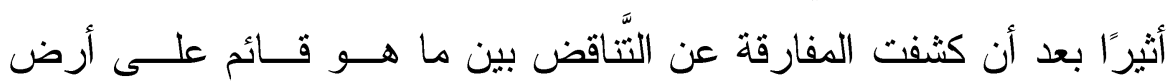

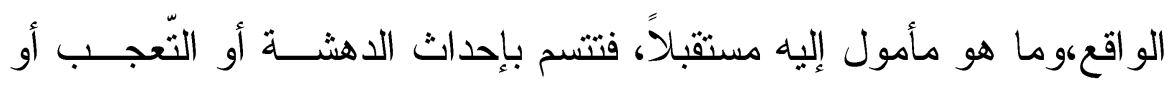
اللذّع لجذب الاهتمام بغرض التّكر و التغيير.

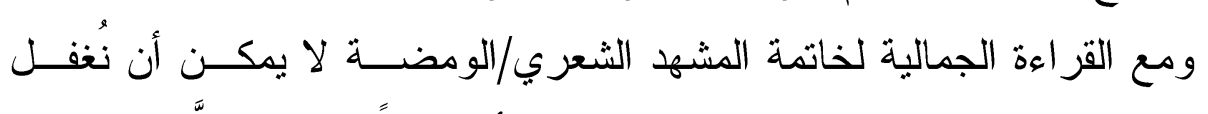

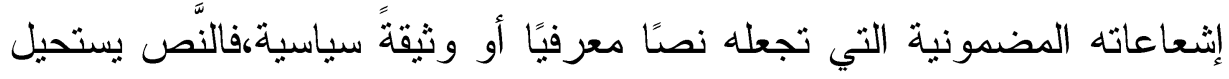

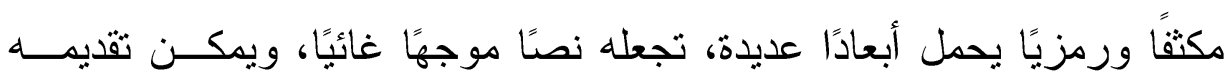

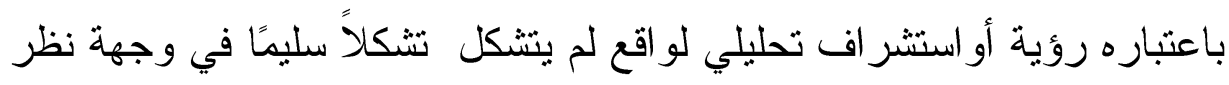
الثاعر .

فالققلة/المفارقة في الإبيجر ام هي بمثابة لحظة التتوير التي تتطلــبـ مقـدرة

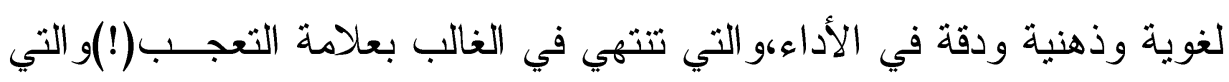

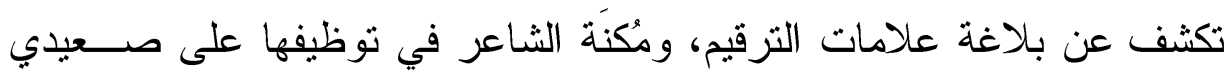
المضمون و الشكل في خاتمة الإبيجر ام.

[11] إن الإبيجرام قد يكون قصيدة قصيرة يحتوي في خاتمته على الومضة/

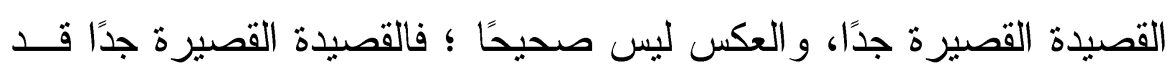

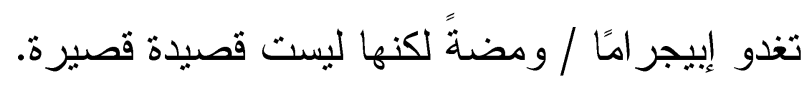

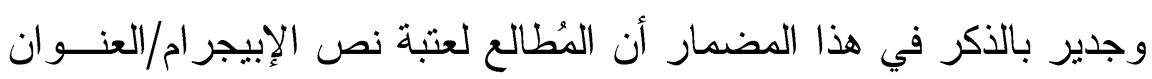

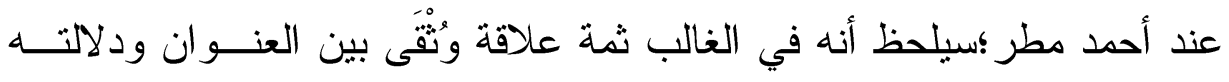

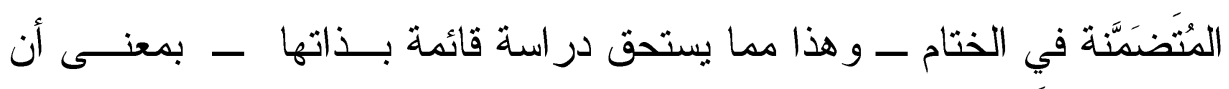

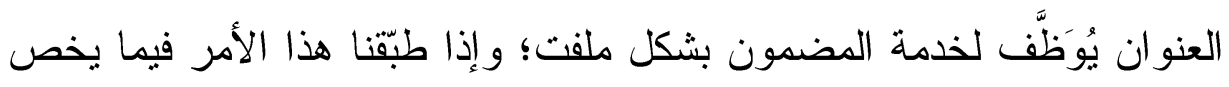

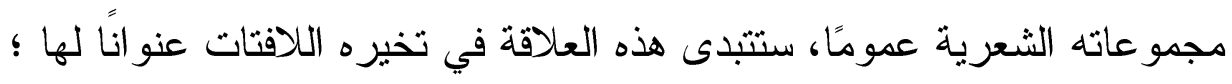

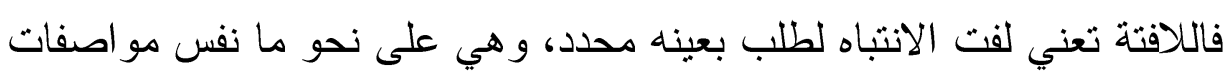
"اللافتة" التي يحملها المتظاهرون من حيث الإيجاز و السهولة و الموقف المُحدَّد

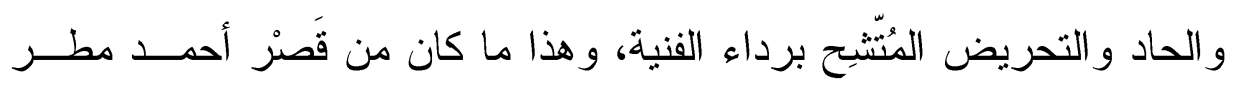




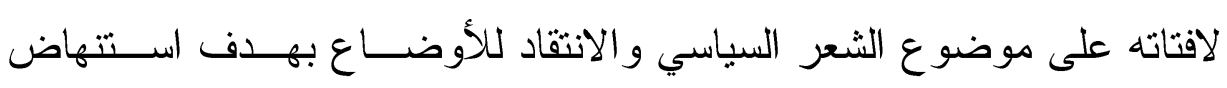

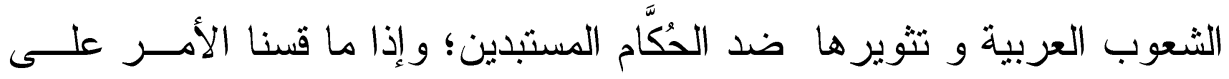
وجه التخصيص داخل اللافتات نفسها لوجدنا أن عنبة نص الإبيجر اج/ العنوان

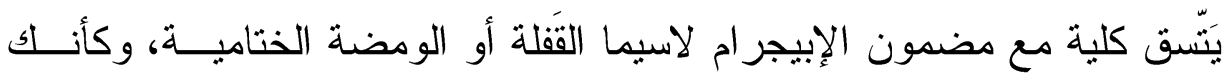

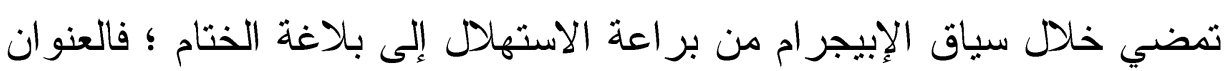
يمثل الإشارة الأولى التي يتلقاها المتلقي لتبدأ عملية القر اعة. [12] اعتد أحمد مطر بنفسه وبشعرهو الإولى اعتد في أنه صاحب رسالة ؛ فالثعر عنده لا يتوقف عند حد كونه إبداعًا جماليًا بل الشعر رسالة إنسانية.

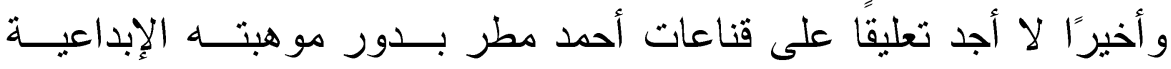

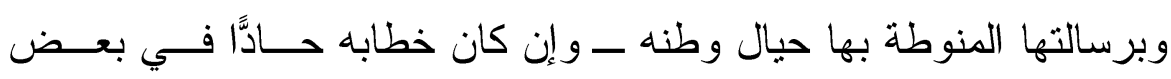
الأحبان - سوى هذه القولة التي تتفتح على عو الم الأدب الإنساني:

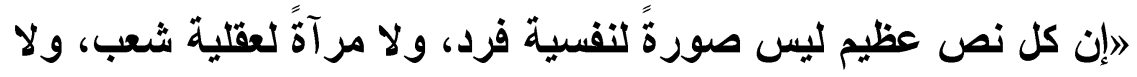

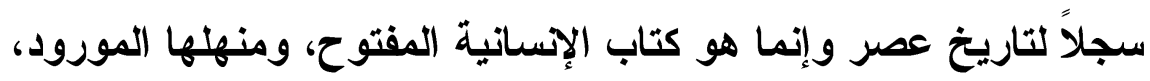
وبعبارة أخرى كل نص عظيم يتجافى عن المشارب والنزعات الاتعكاسية

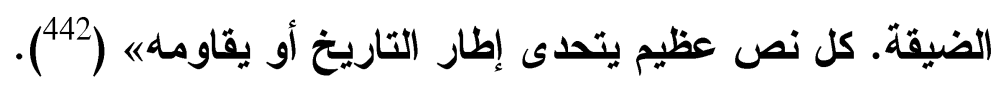

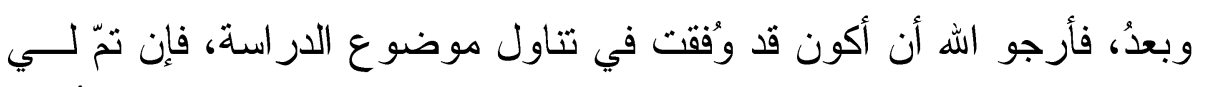

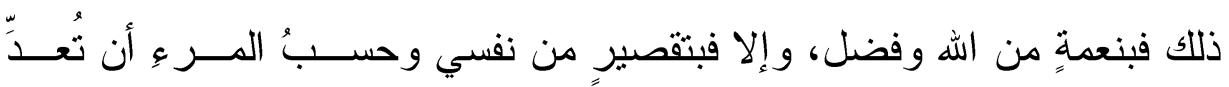
معايبه. و الحمد لله6،، 


\section{الأهو امش}

1 ) مها هلال محمد:قر اعة أسلوبية في قصيدة (أعرف العب ولكن ) لأحمد مطر ،( وهـي القصيدة الوحيدة في مجموع أعماله التي أثشار فيها إلى الرومانسية (ولكن ) حرّم على نفسه الكتابة في هذا الغرض حتى تتغير الأوضاع في أمته ـ على حلى تعبيره

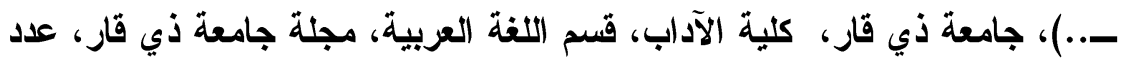

\section{خاص، مجلد5، 2010م، ص}

2) مقدمة الايوان: مجموع حوارات منتخبة لله، ص 11.

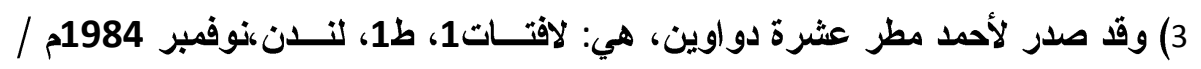

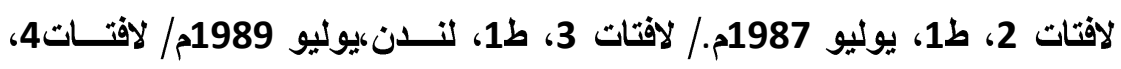

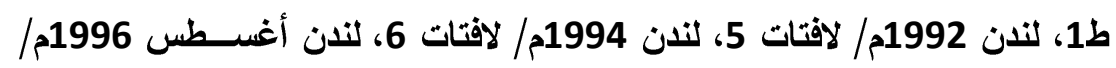

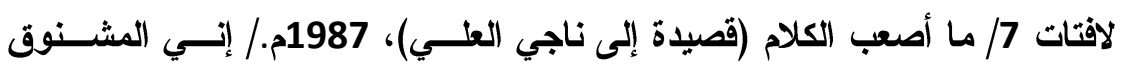

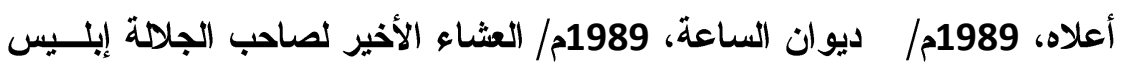

$$
\text { الأول، 1990م. دار العروبة، بيروت 2011م. }
$$

4 ) محمد فؤاد السلطان: دراسة الغضب والتمرد في شعر أحمد مطر،قسم اللغة العربية -

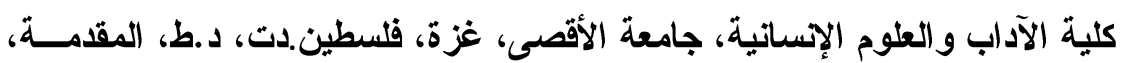

\section{1 ص 1}

5) لافتات أحمد مطر : لافتة رقم 4، ص 13.

6) لافتات أحمد مطر : لافتة رقم 1)، ص لو 154 7) راجع حواراته عبر مواقع إلكترونية،قام على جمعها وتحقيقها معد الأعمــال الكاملـــة

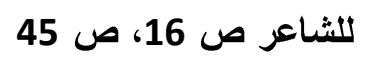

8) لافتات أحمد مطر : لافتة رقم 2، ص37. وقد صور لافتاته بالفأس الأي يقتلع الأوثان،

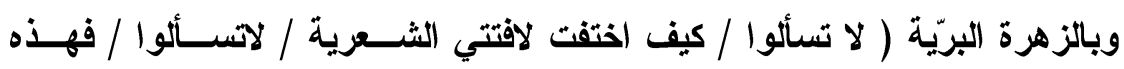

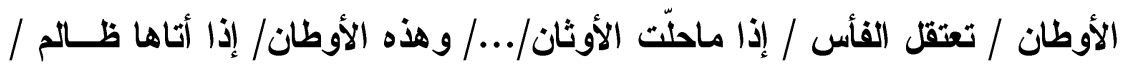

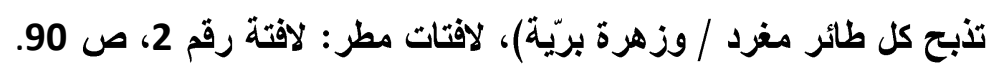
9) يوسف نوفل: طائر الشعر، ص345 


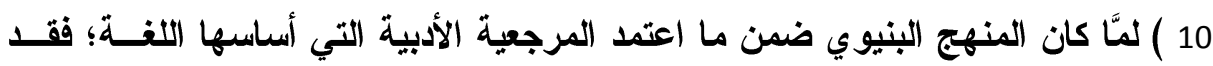

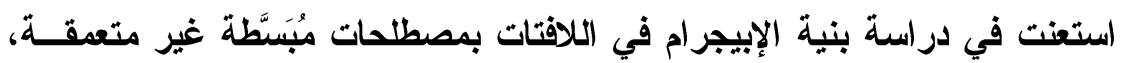
راجع: نظرية الأدب في القرن العشرين: ك.م. نيوتن، ترجمة عيسى العاكوب،عين الإبر

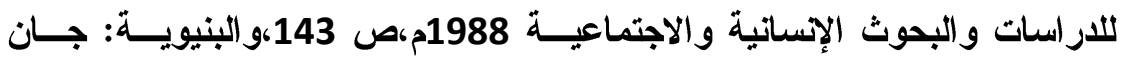

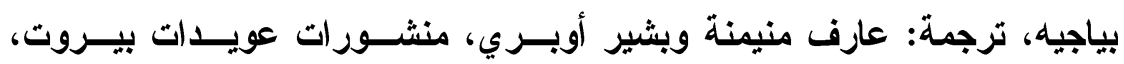
باريس،ط4،1985م،صه، عز الاين المناصرة، علم الثعريات قراعة مونتاجية في أدبية الأدب، دار مجلاوي، عمان، طارب، 2007م، ص 475، 476، وانظر : إبراهيم

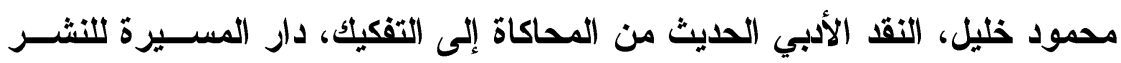
و التوزيع، ط1، 2003م، ص 95، و ديفيد بثنبدر، نظرية الأدب المعاصر وقر اء ة

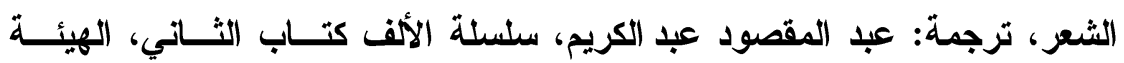

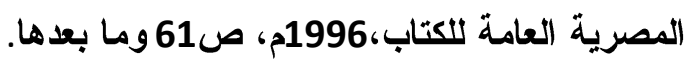

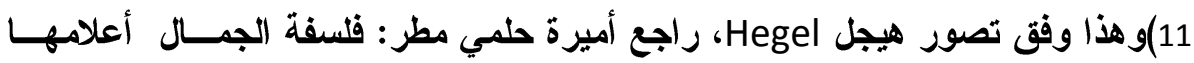

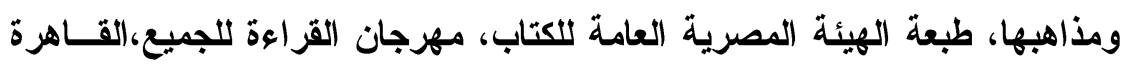
r. . . rم، ص 145: 170، وراجع لها: مقدمة في علم الجمال، طبعة دار النهضة

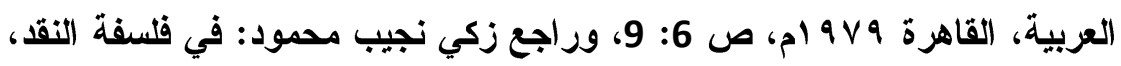

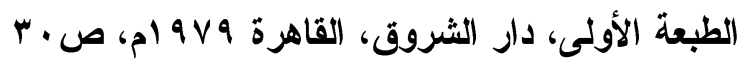

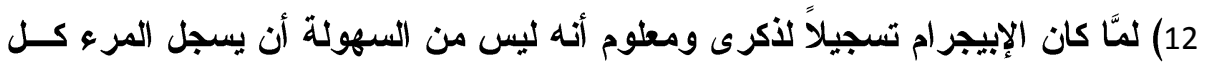

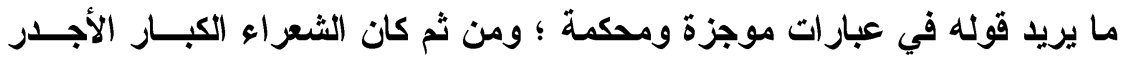

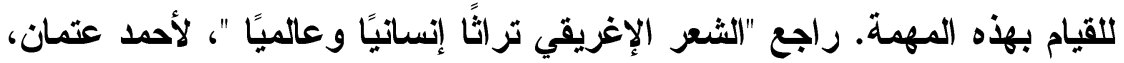

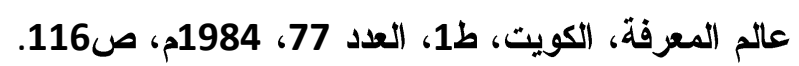
Studien Zum Ghechischen Epigramm, Neue jahrbu Fur das )13 Klassische Aiter tum,19,1917,p.22.

14) طه حسين: جنة الثولك، دار المعارف بمصر، صدرت الطبعة الأولى عـام 1945م، ط11، القاهرة،1986م، وحديثه عن مبدعي اليونان، ص 8. و وراجع محمد حدي

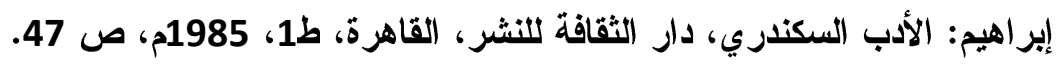

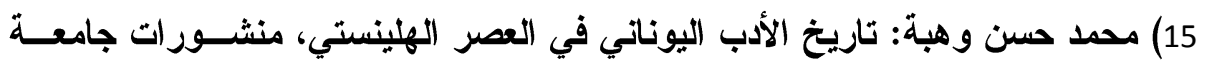

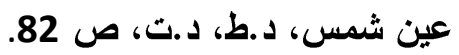
doi: $10.12816 / 0010463$ 
16) محمد حمدي إيراهيم: الأدب (السكندري، ص 8.

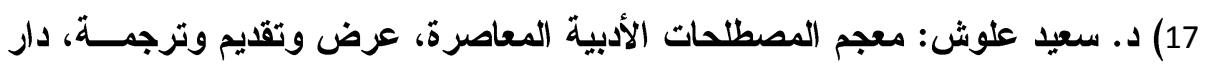

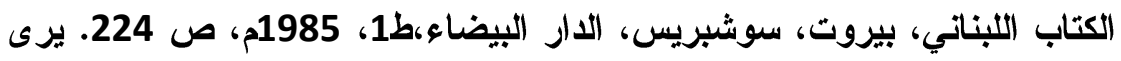
د. يوسف نوفل: طائر الثعر،عش الفيض.. فضاء التأويل،أن الثـاعر عــز الــــين المناصرة من الرواد الأين كتبوا قصيدة الإبيجرام،ويشير إلى أن المناصرة يصرح

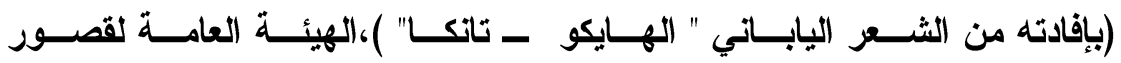
الثقافة،القاهرة، ط1، 2010م، صن مالبن 239.

The New Enseclopaedia Britannica, p,923.( 18

19) عبد الغفار مكاوي: قصيدة وصورة،الثعر والتصوير عبـر العصور،سلســلة عـالم

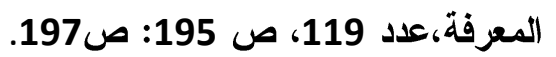

20) و الترج. أونج: كتاب الثفاهية والكتابية، ترجمة د. حسن البنا عز الاين، مراجعة د. د. محد عصفور، عالم المعرفة، الكويت، عدد 182، فبراير 1994م يقول: (.. مسن

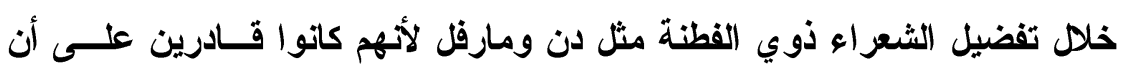
يجمعوا بين الفطنة والجدية،.. والحذق في القول كما في الإبيجرام. ذلك أن الفطنة

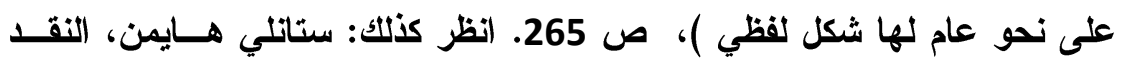
الأدبي، ومدارسه الحديثة،ترجمة إحسان عباس ومحمد يوسف نجــم، دار الفكـر العربي، القاهرة، د.ت، ج1؛حيث ترجم المترجمان المصطلح ب" قوة اللمح الساخر

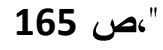

Udson,H.H, The Epigrama in The English Renaissance, (21 Princeton,University Press,New Jersey. U.S.A,1947,p.17.

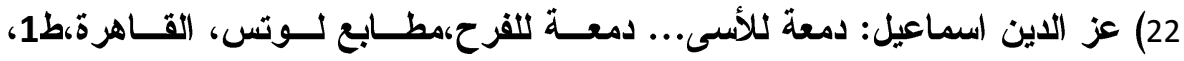
2000م، ص 13.

23)The New Enseclopaedia Britannica ,Micropedia Volum III 15th Edition, Helen Heming Way benton Publisher,1973-1974, p.924-

Herausge Ben Von Otto Kno"rrich:Former der Literatur in Einzel (24 Dar Stellungen, Epigram, Alfred Kro"ner Verlag( STUTTGART) , 1981,P.66. 
عنوان الكتاب: الأثكال الأدبية، عرض منفرد، وتضمّن الحديث عن المقال، والإبيجـرام،

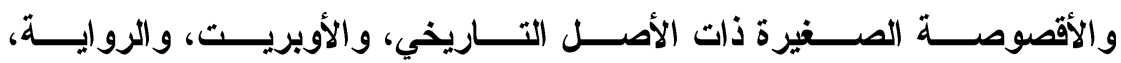

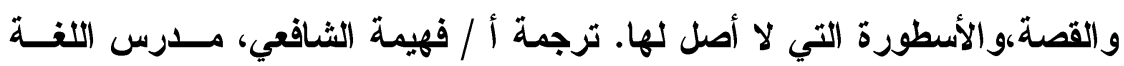

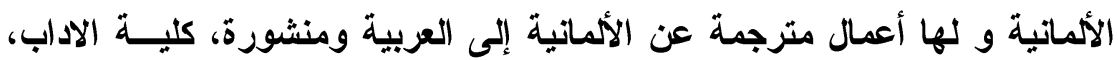
جامعة دمنهور.

Book title: Buch Von Der (Deutschen) Poeterey,Author; Martin )25 Opitz , Max Niemeyer Verlag, TUBINGEN, 1966,P.1- 57. عنوان الكتاب: كتاب الثعر الألماني: لمؤلفه مارتن أوبيتذ 1624م، وأعــادت نشــره دار ماكس نيماير عام 1966م، وتضمّن الكتاب الحديث عن فن الإبيجرام خصائصه من

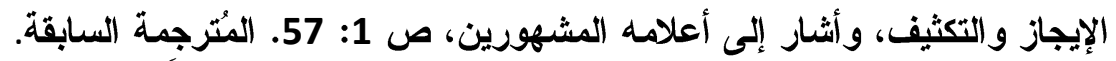

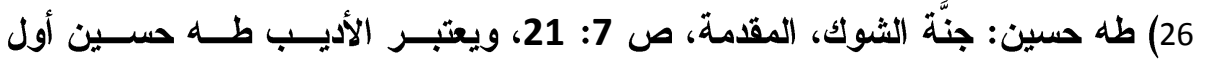

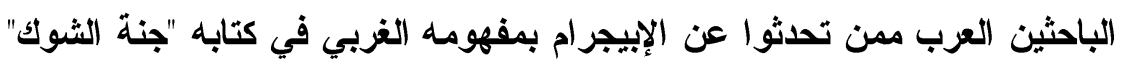

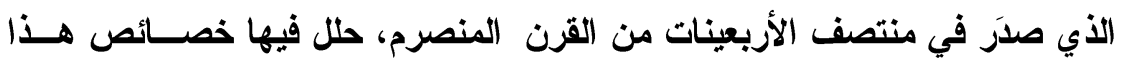
الفن وتحدث عن تاريخه في الآداب الأوروبية قديمًا وحديثًا.

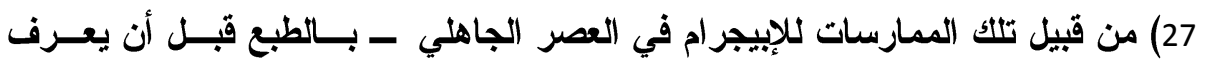

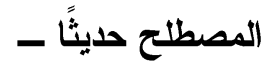
( ما نظمه الأعشى..، والحطيئة..، وما قال أبو فرعون الساسي..، وما قال ابن الرومي.. وأقوال بثار الثعرية..، وحتى نصل إلى العصر الحديث... وما قـ أوصى إبــر اهيم

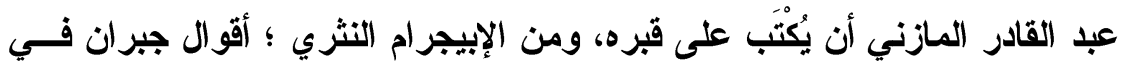

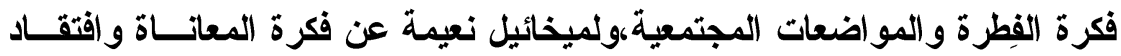
العدالة، ولأنيس منصور في المرأة )، نقلا عن إبراهيم عوض: كلام مثـل عدمـــهـ

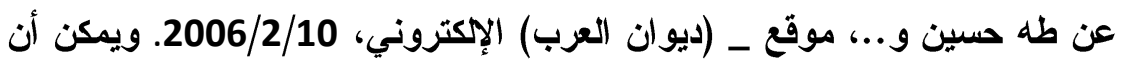

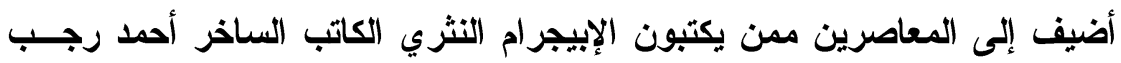
في جريدة الأخبار " نصف كلمة". ومن ثم نتفق ما قاله د. عز الدين إسماعيل من

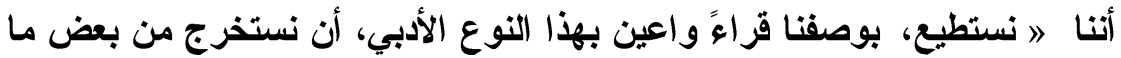

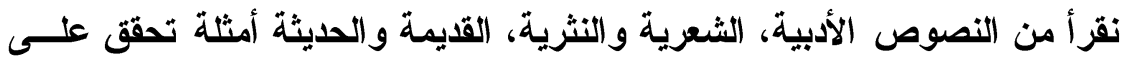

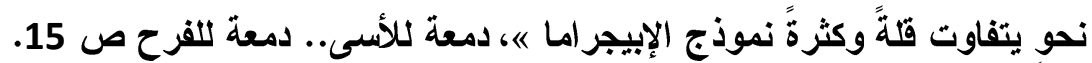
doi: $10.12816 / 0010463$ 
28)طه حسين: جنة الشوك، ص 9 29) نفسه: ص13.

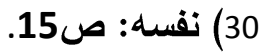

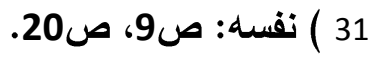

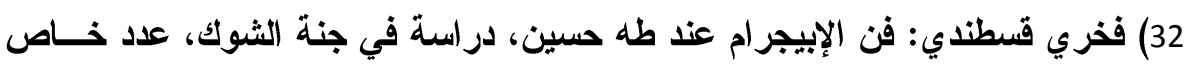

عن الأدب المقارن،عدد يوليو وأغسطس سبتمبر، 1983م، ج2، ص هـ 81: 102. 33) مجدي وهبة:معجم مصطلحات الأدب، مكتبة لبنان، 1991م.

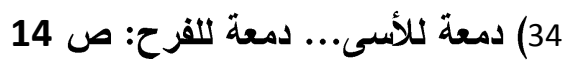

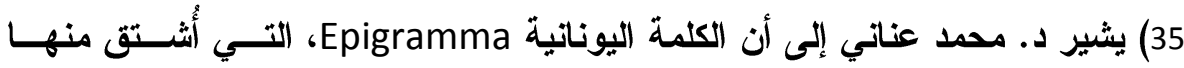
مصطلح Epigram ؛ تعني النقش Inscription، أما المصطلح Epigram فيعني " تركيز أو إيجاز أو قوة التأثير الالالي للعبارة "، راجع

Mohammad,H.Time in The Wilderness,trans,Andintro by M.Enani,Gener al Egyptian Book,Cairo,2000,P.8.

36) طه حسين: جنة الشوك، ص 11

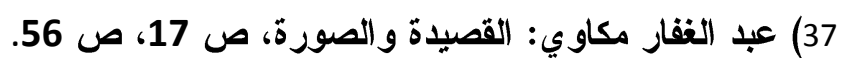

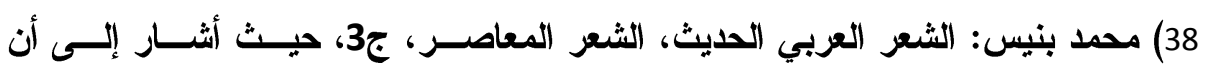
أدونيس يكتب (قصيدة الإشارة)، دار توبقال للنشر، الدار البيضاء، المغرب، ط25،

1996م، ص 95

39 ) د. يوسف نوفل: طائر الشعر، عث الفيض... فضاء التأويل، ص 299.

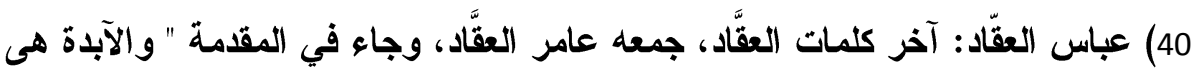

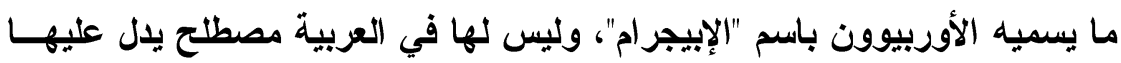

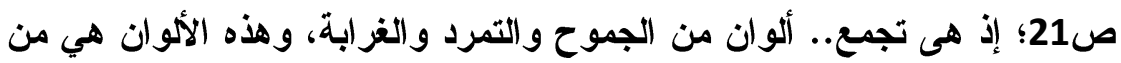

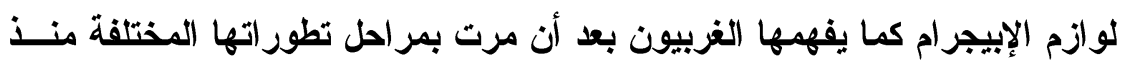

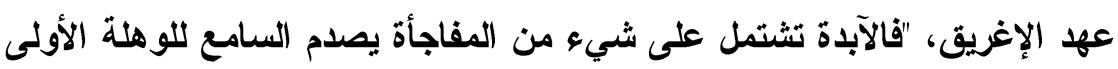

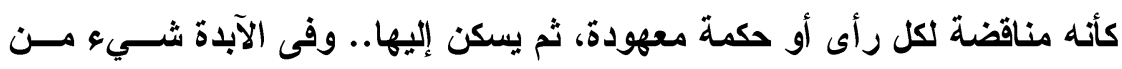

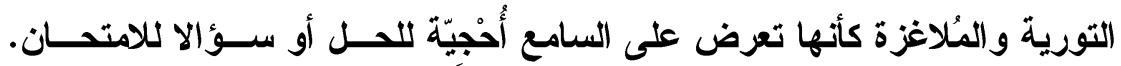

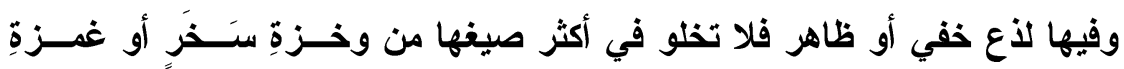


تبكيتٍٍ، وتتأخر فيها اللذعة إلى ختامها فتمرّ مأمونة سليمة إلى كلمتها الأخيرة، ثم

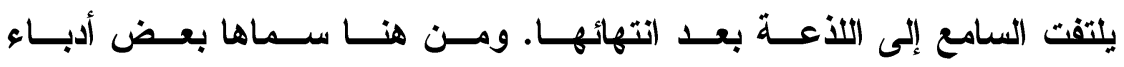

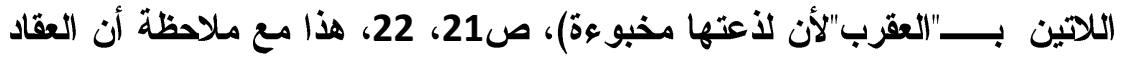
لم يقل قط إن ما كان يكتبه في مفكراته بين الحين والحين هو إبيجـرام. سلســـة

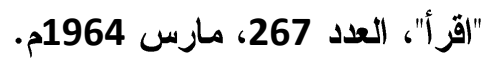

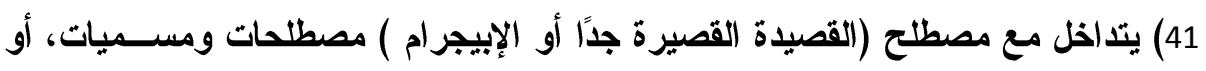
هي ربما صفات أخرى قـ تضيق فجوة الفَق بينها وبين المصطلح محل الــدرس، أو تتسع، والباحثة ترى أنها لا تزيل عن كونها مسميات مختلفة لمعان متقاربة إنْ

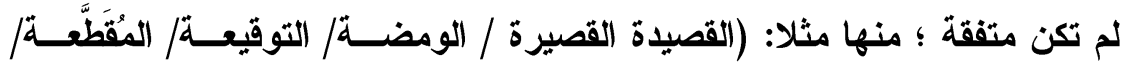

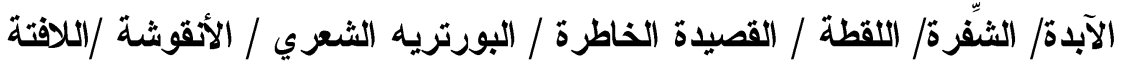

$$
\begin{aligned}
& \text { / الخبرية/ الهايكو/ السونيتة / البرقية/التكس ) . } \\
& \text { 42) جنة الشوك: ص } 12 . \\
& \text { 43) نفسه: ص } 13 \\
& 44 \text { ) نقسه: (الصفحة نفسها. } \\
& \text { 45) نفسة: ص } 8 \\
& \text { 46) نفسه: ص 4 (4) } 15 . \\
& 47 \text { ) نفسه: ص 15، وما بعدها. } \\
& 48 \text { ) نفسه: ص } 16
\end{aligned}
$$

49) عز الاين إسماعيل: ديوان "دمعة للأسسى.. دمعة للقرح"، المقدمة، ص 14، 15.

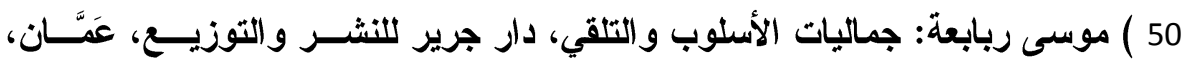

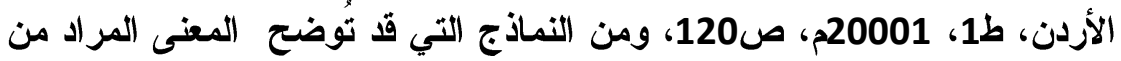
أن اللغة لم تعد أداة تعبير بل وعاء للإيحاء بظلال وأبعاد وعو الم مشعة حتى مسن

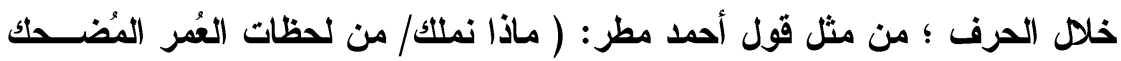

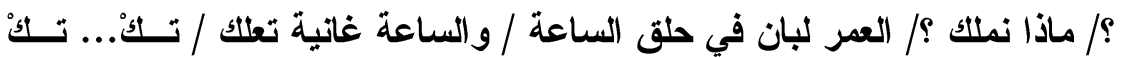

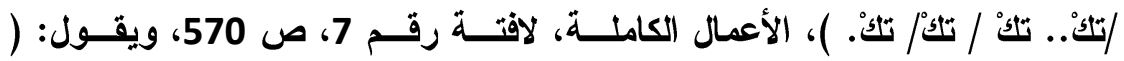




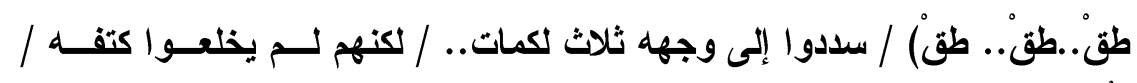

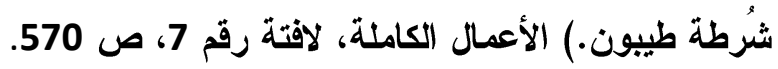

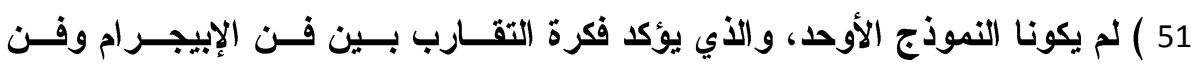

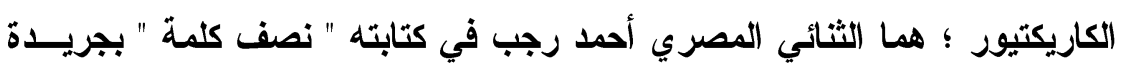

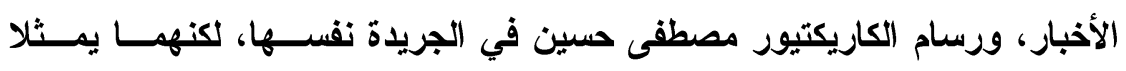
التلاقي النثري ؛ أي الإبيجرام النثري.

52) عمر عتيق: ثقافة الصورة، دراسة أسلوبية، مجلة جامعة القدس المفتوحة للأبحــاث

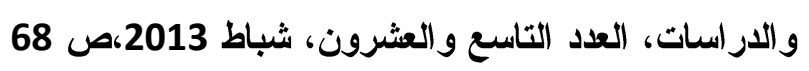

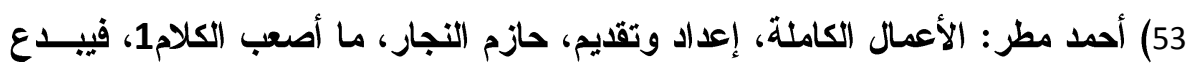

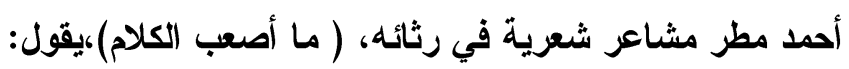

$$
\text { تفوًا ؛ فإني ميت با أيها }
$$

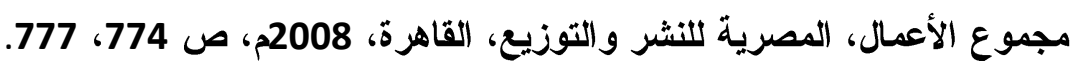

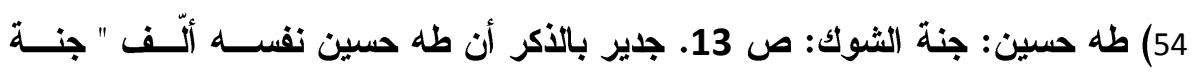

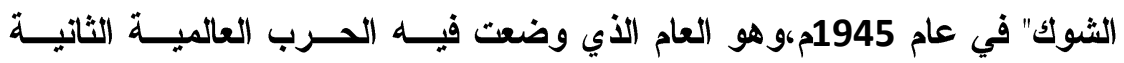

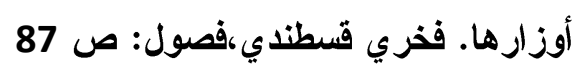

55) لقد كتبها غوتة حين كان وحيدًا ومُجبرًا على الإقامة في البندقية وبعيدًا عن ألمانيا،

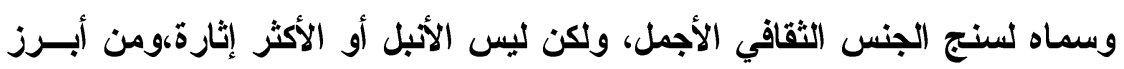

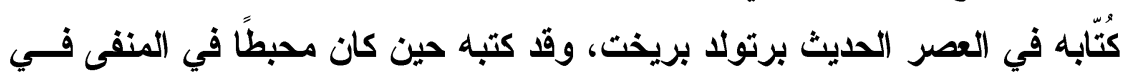

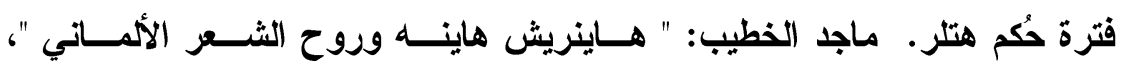

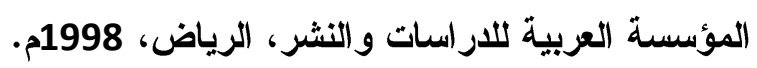

56) التوصيف مقتبس من حديث د. محمد عبد المطلب: " شعر اء السبعينيات وفوضــاهم

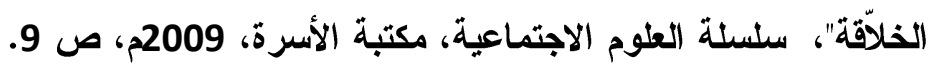

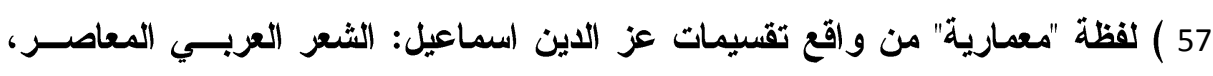

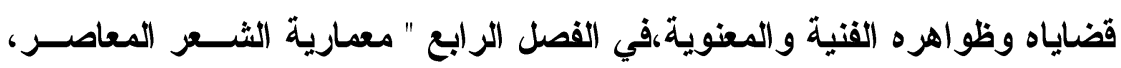

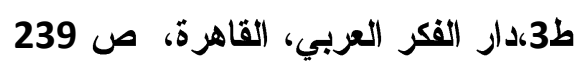


58 ) صلاح فضل: بلاغة الخطاب وعلم النّص،سلسلة عالم المعرفة،عدد 164، الكويـــ، 30 1992 192

59 ) نور الاين السد، الأسلوبية وتحليل الخطاب ( دراسة في النقا العربــي الحــديث )، تحليل الخطاب الثعري والسردي، دار هومة، الجزائر، 1998م، ج1، ص 16.

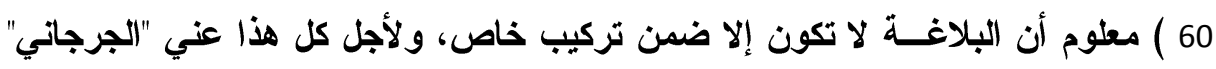

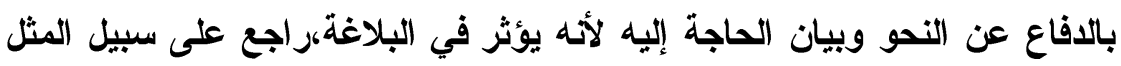
لا الحصر:صالح بلعيد:التراكيب النحوية وسياقاتها المختلفة عند الإمام عبد القاهر لإنه

الجرجاني، ديوان المطبوعات الجامعية،ط1،

61 ) صلاح فضل: بلاغة الخطاب، ص 22.

62 ) نفسه: بلاغة (الخطاب، ص 63 )

63 ) عز الادين اسماعيل: الشعر العربي المعاصر، صل صل 174.

64 ) محمد عبد المطلب: تقابلات الحداثة في شعر السبعينات، كتابات نقدية، العـدد 45، الهيئة العامة لقصور الثقافة، 1995م،ص158.. د. د. صلاح فضل " بلاغة الخطــاب

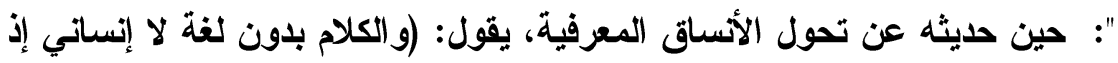

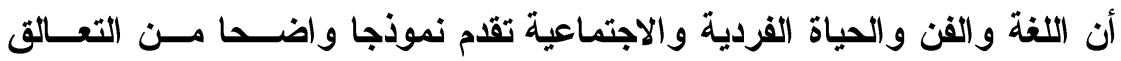

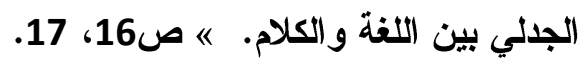

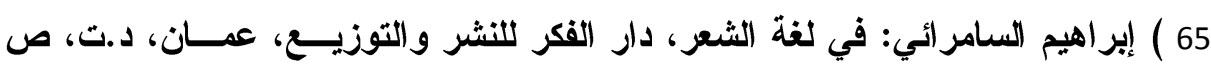

La critique, Collection, Contoure Littéraires, Sous La Direction de ( 66 . BRUNO VERCIER. Paris, 1994 ANNE MAUREL:

من جاتب الأثر الإبداعي،النقد البنيوي لآن مورال، ترجمة بريهمات عيسى،45. المقال

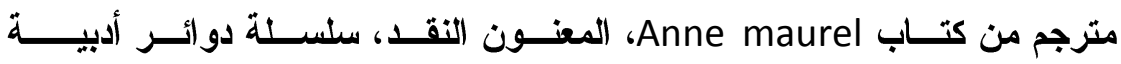
• 1994، Hachette جوزيف مشال شريم، دليل الار اسات الأسلوبية، المؤسسة الجامعيــة للار اســات و النشــر والتوزيع، لبنان، ط1، 1984، ص 85. 
67 ) جان كوهن: بنية اللغة الثعرية، ترجمة محمد الولي ومحمد العمـري، دار تويقـال

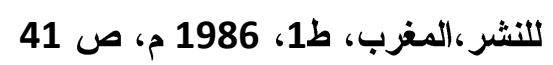

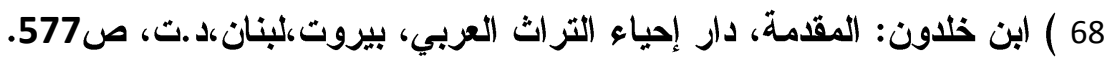

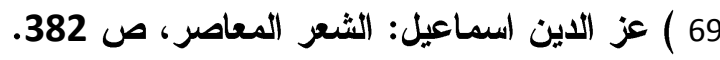

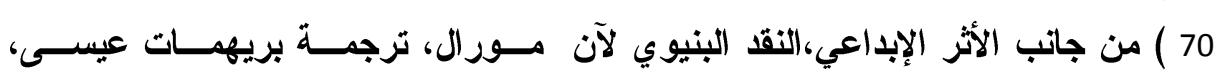

$$
\text { ص } 52 .
$$

71 ) حامد عبد القادر: دراسات في علم النفس الأدبي، القاهرة، 1949م، ص 135. 72 ) ماهر مهدي هلال: جرس الألفاظ ودلاتتها في البحث البلاغي والنقدي عند العرب،دار

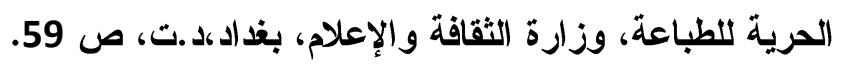

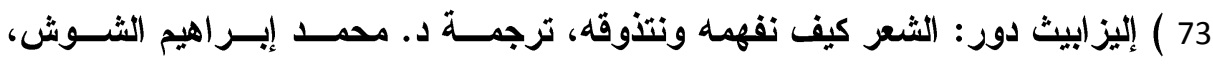

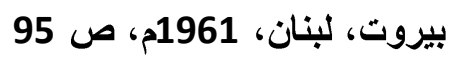

74 ) حازم القرطاجني: منهاج البلغاء وسراج الأدباء، تحقيق محمد الحبيب بن الخوجــة،

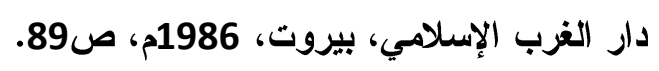

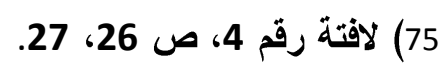

76 ) أرشا بالا مالكش: الثعر وفم والتجربة، ترجمة سلمى الخضــراء الجيوســي، مراجعـة

$$
\text { توفيق صايغ، بيروت، 1963م، صاندال } 22 .
$$

77 ) يقول صلاح فضل في بلاغة الخطاب: اذلك أن اختيار الكلمات و البنى المتمثــــة فــي

$$
\text { الجمل والمتتاليات }
$$

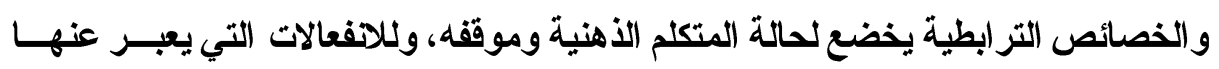
بهدف حث قارئه أو المستمع إليه على تفسير هذه المميزات الأسلوبية كإثار ات إلى

$$
\text { حالته (النفسية في وقت معين،،ص192 }
$$

78 ) مجموع الأعمال: لافتة رقم 7،ص 547. وله قريب من معنى هذا الإبيجرام ( أكــاد

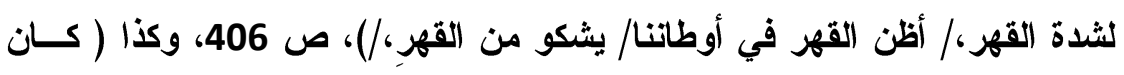

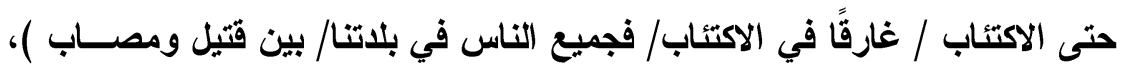
ص ص 81. 79 ) لافتات أحمد مطر : لافتة رقم2، ص140. 
80 ) الأعمال الكاملة: لافتة رقم 1، ص 207، 208. 81 ) الثاعر ممنوع من دخول الكثير من البلدان العربية، وهو يقيم بلندن، ثائر الأسدي:

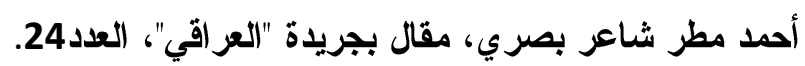

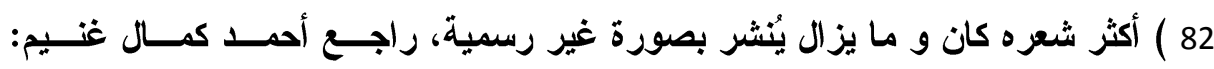

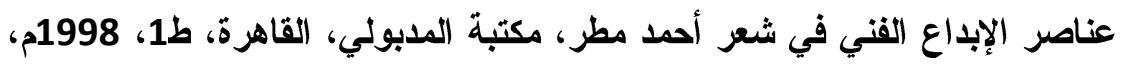

ص 43.

83 ) الأعمال الكاملة: لافتة رقم 1، ص ص 250

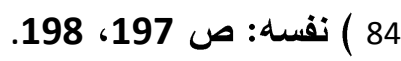
85) فوزي عيسى: تجليات الثعرية، قر اعة في الثعر العربي المعاصر،منشأة المعسارف،

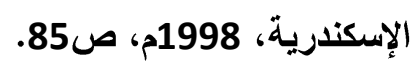

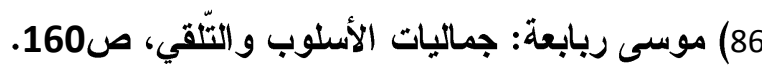
87 أضعها ضمن هلالين

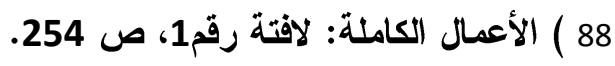

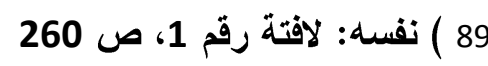

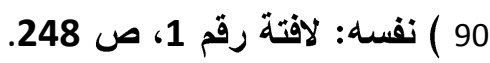

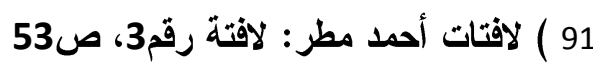

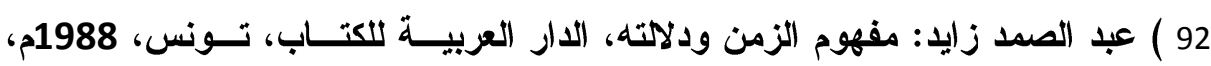
ص12. 93 ) هاتز ماير هوف: الزمن في الأبب، ترجمة أسعد مرزوق، مؤسسة فرانكلين للطباعة

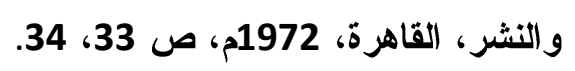

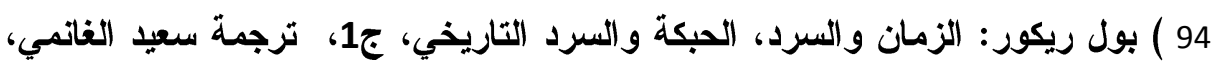

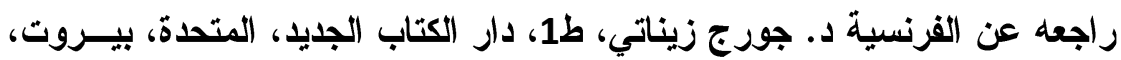

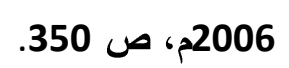

95 ) عزوز علي اسماعيل: شعرية الفضاء الروائي عند جمال الغيطاني، دار العين للنشر،

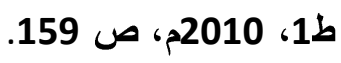


96 )محمد رضا مبارك: اللغة الثعرية في الخطــاب النقـــي العربــي ؛ تــلازم التـــــاث

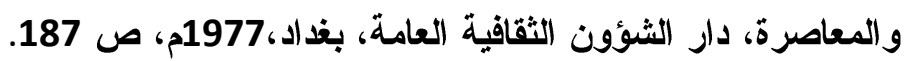

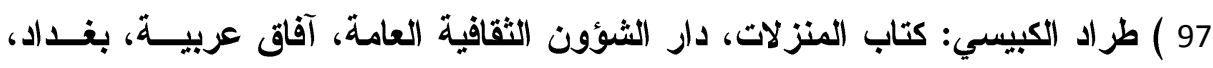

$$
\text { العراق، 1995م، ج2، ص28. }
$$

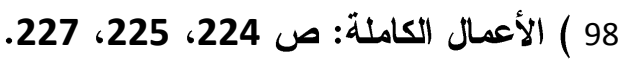

99 ) من الطريف أنه لاى أحمد مطر إبيجرام يعلق فيه على الألوان وما تمثل من صــور

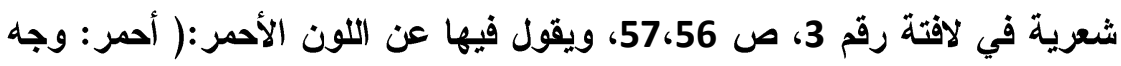

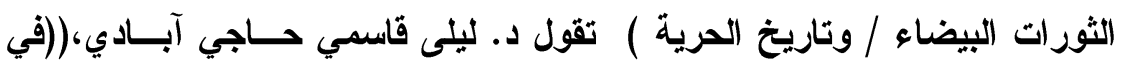

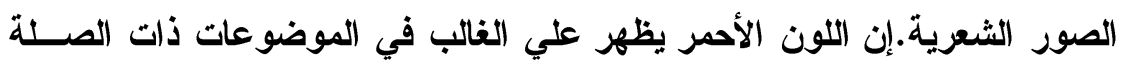

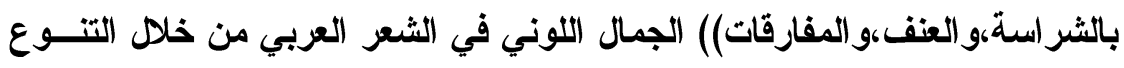

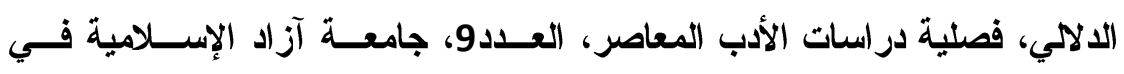
كرمسار،إيران، 1390 هـ، شفيق جبري:لغة الألوان، مجلة مجمع اللغة العربية،

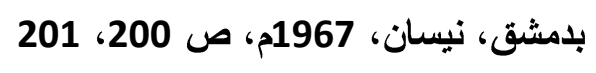

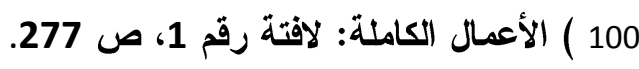

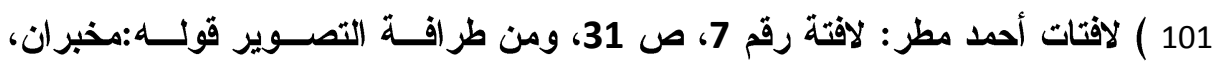
وظلال التحليل المتسعة لبراعة الابتكار في الصورة ؛ ققد بعني بالمخبرين عقربي

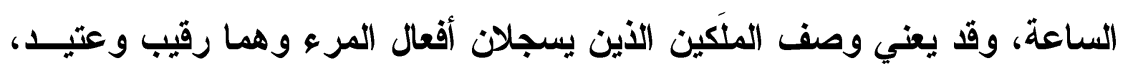

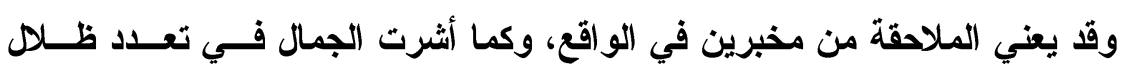
التأويل.

102 ) الأعمال (الكاملة: لافتة رقم 7، صالت 103

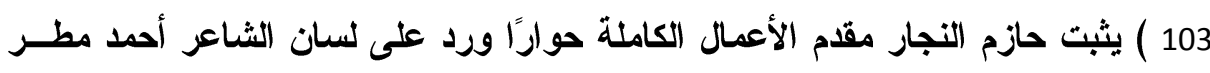
مختصره أنه يؤمن بمقولة إن عُمر الإنسان يُحسب بعدد الأعــوام التــي عاثـــــانها

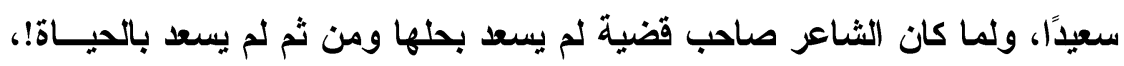
راجع مقدمة الأعمال الكاملة، ص 8، 9.

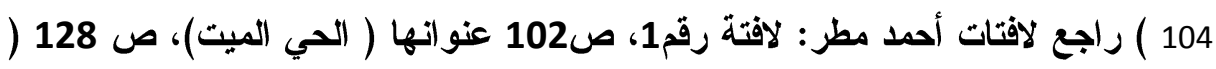

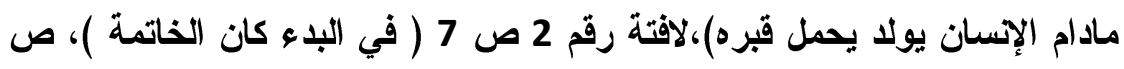




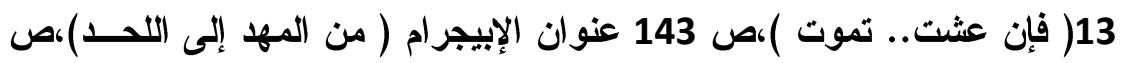

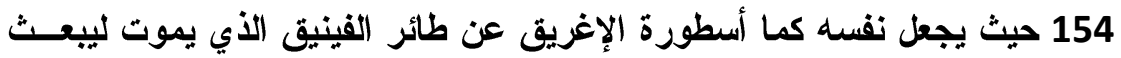

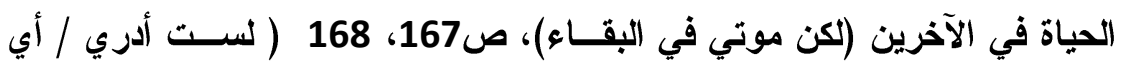
معنى للمسافات التي / مابين ميلادي وقبري)، لافتة رقم 3، ص 51 ( لايحيــا إلا

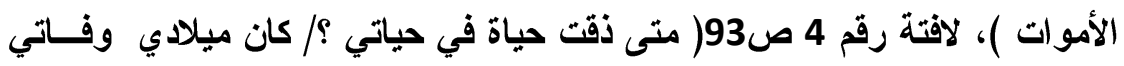

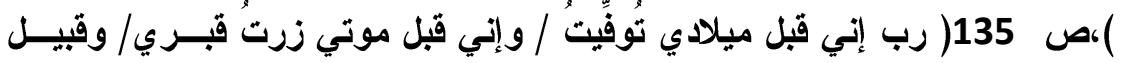

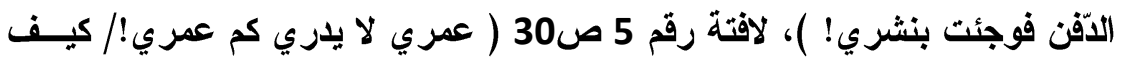

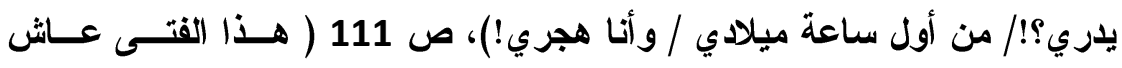

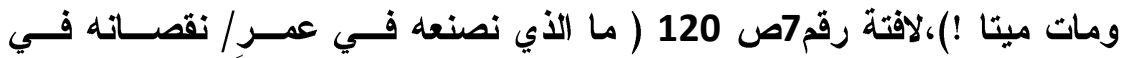

105 ) الأعمال الكاملة: لافتة رقم 7، ص الاد 1066.

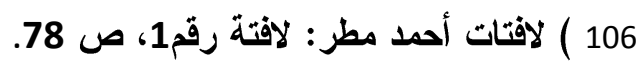
107 ) نفسه: لافتة رقم 2، ص 166. 108 ) نفسه: لافتة رقم 4، ص اله 22 109 ) جالك شورون: الموت في الفكر الغزبي، ترجمة كامل يوسف حسن، مطبعة الرسالة، (الكويت، 1984م، ص صدون 23.

110 ) نازك الملائكة: قضايا الثعر المعاصــر، مكتبــة النهضــة، بغــداد، ط2، 1965م، ص ص272. (1)

111 ) الأعمال الكاملة: إني المشنوق أعلاه، ص 90.

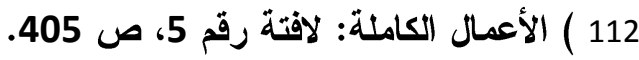
113 ) وكأن الثاعر يؤمن بأسطورة ( الفينيق ) الإغريقية ؛ حيث في الموت بعث وحيـاة

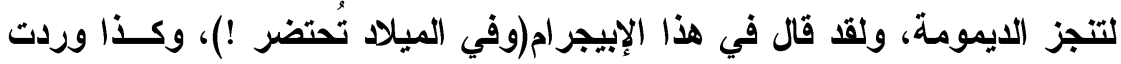
هذه الفكرة في إبيجرام آخر فقال: (والبرد باق / ثم لايبقى / إلا رماد الاحتراق )، الأعمال الكاملة: ص 85 114 ) لافتات أحمد مطر : لافتة رقم 2، ص 198،197.

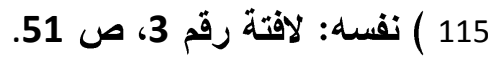


116 ) الأعمال الكاملة: لاقتة رقم7، ص637.

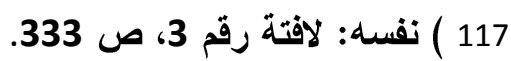
118 ) عبد القادر فيدوح: الاتجاه النفسي في نقد الشعر العربي،منشورات اتحـــاد الكتّــاب

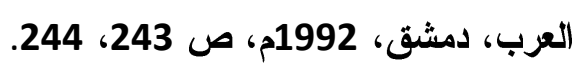

119 ) د. علي إبر اهيم: الزمان و المكان في روايات غائب طعمة، دراسة نظرية تطبيقيــة،

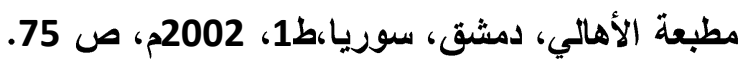

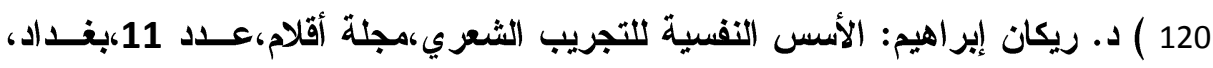

$$
\text { 1989م، ص } 46
$$

121 ) انظر الصفحات (لقادمة من الاراسة في مبحث بنية الالالة ؛ حيث ســيتم الإثـــارة لطبيعة الزمن عنده

122) هكذا (الصياغة بالنص الأصلي.

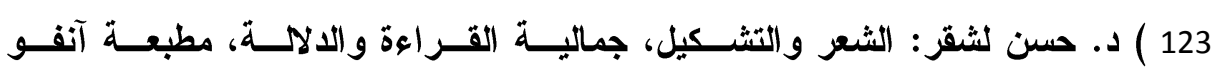

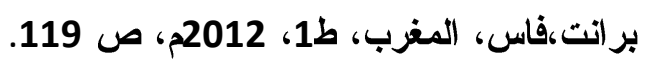

124 ) الأعمال الكاملة: لافتة رقم 1، ص 172 ( ومن وهران إلى الظهران: / عَدْلَ ملانكةِ

$$
\text { (الرحمن). }
$$

125 ) نفسه: لافتة رقم 7، ص 620 لافتة " عائد من المنتجع" جاء فيها ( فــالر أس فــي إنجلترا، والبطن في تانز انيا، والأيل في اليابان!).

126)على سبيل المثل لا الحصر لافتات مطر، لافتة رقم 7 " لامفر"، وحديث عـن أمريكــا

$$
\text { و إسر ائيل، ص }
$$

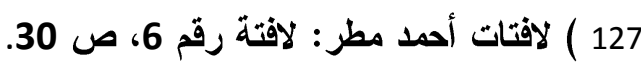

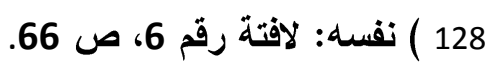

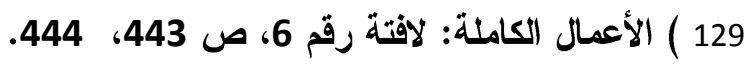

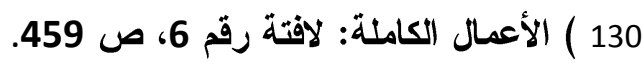

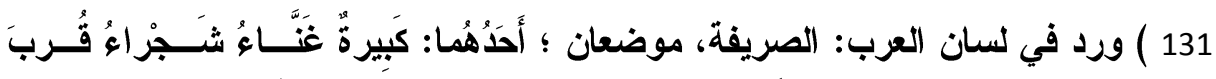

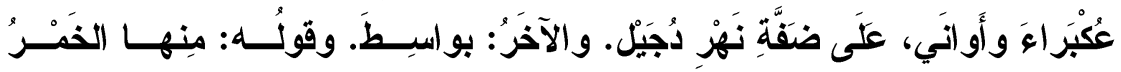


الصَّريفِيَّةُوحديثًا صارت الصريفة في العراق تعني البيوتات البسيطة المصــنوعة من السعف اليابس.

132 ) لافتات أحمد مطر: لافتة رقم 7، ص 133)الأعمال الكاملة: لافتة رقم 3، ص 343. 343. ويقول: " أنثأت من منفاي أوطانًا لأوطاني

$$
\text { الطريدة " ص } 229
$$

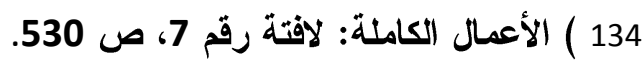

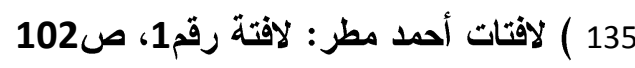

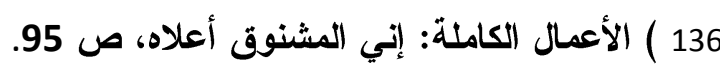

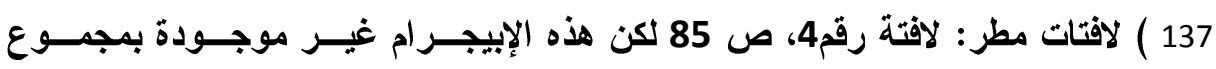
الأعمال.

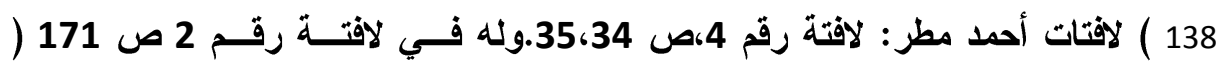
/ Me ? ) و (Made in USA

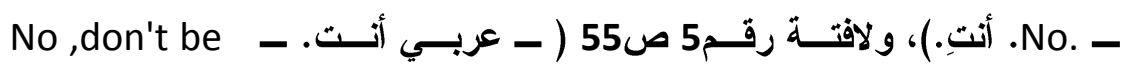
S.Silly,thay

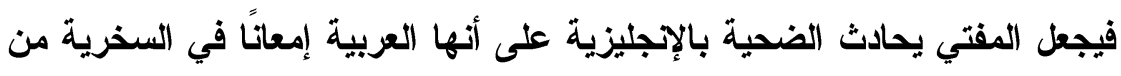

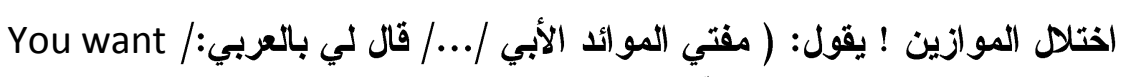
to be really happy? (139) رينيه ويليك، واستن وارين: نظرية الأدب، ترجمة محي الاين صبحي، المؤسسـة

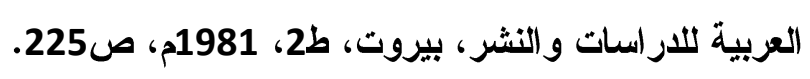

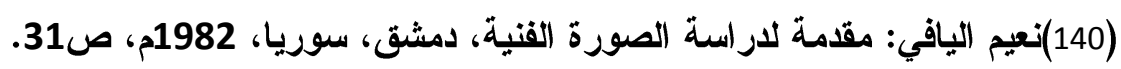
(141) عبد السلام المسدي:الأسلوب والأسلوبية؛ نحو بديل ألسني في النقد الأدبي، الــــار العربية للكتاب، تونس، ط3، د.تصوبلد (142) محمد غنيمي هلال: النقد الأدبي الحديث، نهضة مصـــر للطباعــة والنشــر،د.ت، ص 173. (143) جان كوهن: بنية اللغة الثعرية، ص95. (144)إبر اهيم أنيس: من أسرار اللغة، مكتبة الأنجلو المصرية، ط7، 1985م، ص219. doi: $10.12816 / 0010463$ 
(145)سناء حميد العبيدي: نحو منهج جديد في البلاغة والنقد الأدبي، منشورات جامعسة قاريونس، بني غازي، ط1، 1998م، صويساء 29.

(146)سناء حميد العبيدي:نحو منهج جديد في البلاغة والنقد الأدبي، ص31.

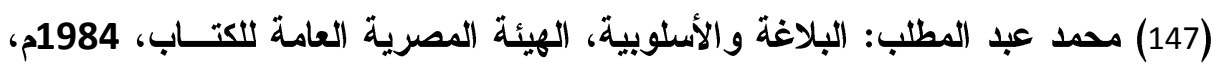
ص 198 148 ) أدونيس: زمن الثعر، دار العودة،بيروت، 1972م، ص20.

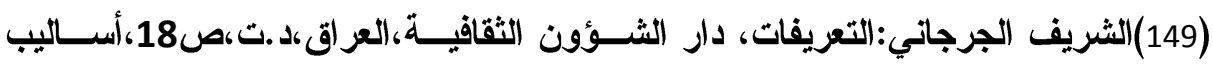
الطلب عند النحويين والبلاغيين، ص308. أحمد عبيس:لغة شعر الشريف الرضي،

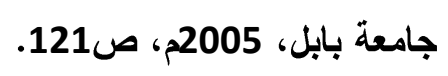

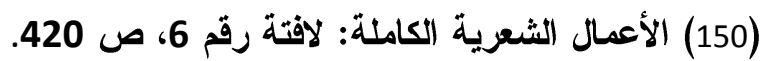

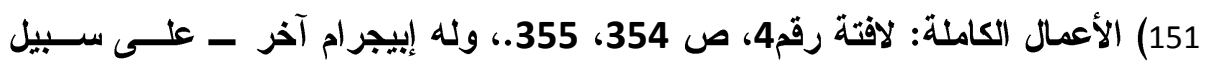

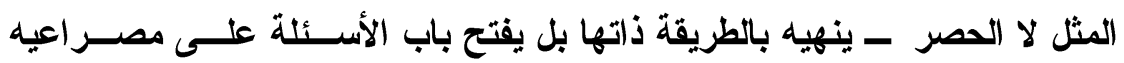

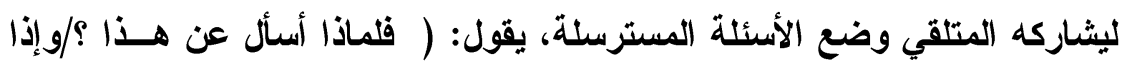

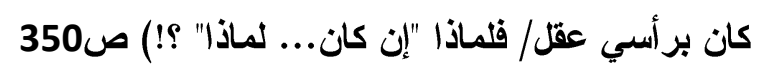

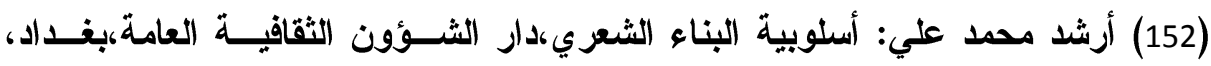

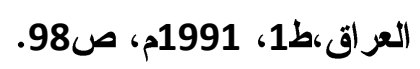

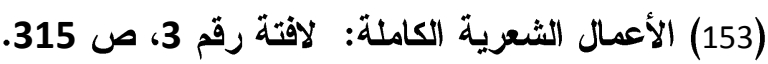
154) نفسه: لافتة رقم 6، ص 434. وله أيضًا على سبيل المثل لا الحصر هذا الاستفهام

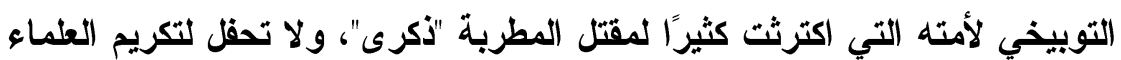

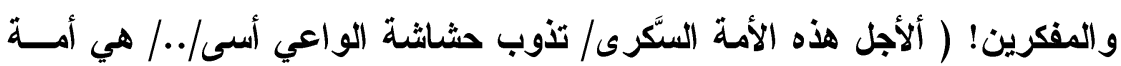

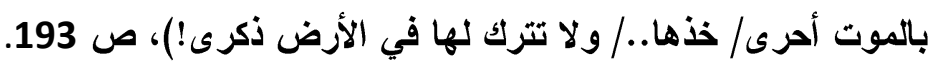
156) لافتات أحمد مطر: لافتة رقم 7) الأعمالة لافتة رقم 7، ص 1557 ص 516. (158) فتح الله أحمد سلمان:الأسلوبية؛ مدخل نظري ودر استة تطبيقية، الدار الفنية للنشـر والتوزيع، القاهرة، 1990م، ص64. 
(159)أبو الحسن أحمد بن فارس بن زكريا: الصاحبي في فقه اللغــة ومســائلها وســن العرب في كلامها، تحقيق أحمد حسن بسج، دار الكتب العلمية، بيروت، لبنان،طن،

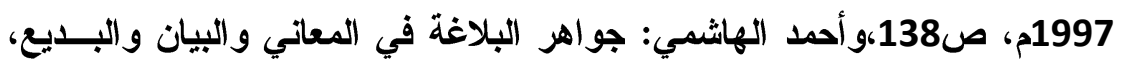

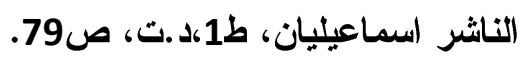

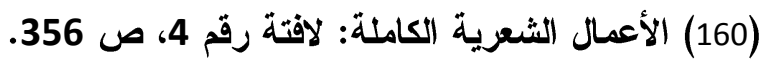

(161) نفسه: لافتة رقم 6، ص 6 (160) 421.

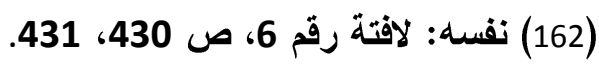

163 ) الصورة هنا على طريقة المتنبي لكنها معكوسة ــ أي إذا أتى مديحي من نـاقص

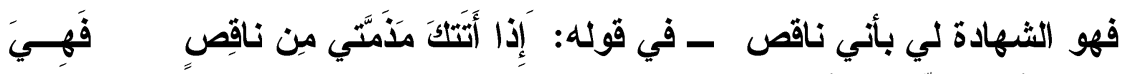

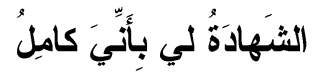

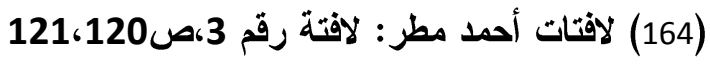

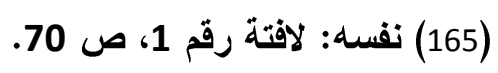

(166) قيس الأوسي:أساليب الطلب عند النحويين والبلاغيين،بيت الحكمة للنشر،1989م،

ص 163.

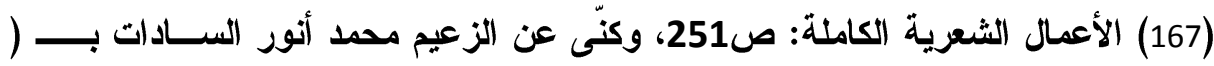

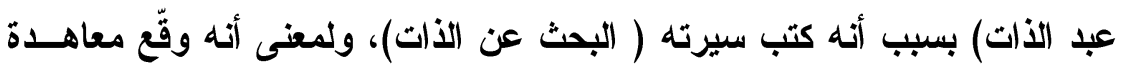
السلام ـ في وجهة نظر الثاعر - وهذه الفكرة تعاقب عليها الكثير من الشــعراء وقت معاهدة كامب ديفيد ؛ ومن أبرزهم أمل دنقل في " لا تصالح". (168)هي (لا الناهية الجازمة والفعل المضارع). راجع يحي بن حمزة بن علي بن إبر اهيم

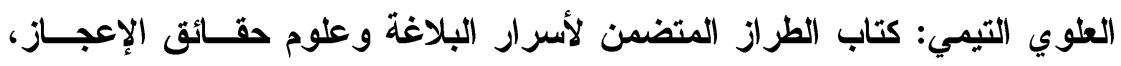

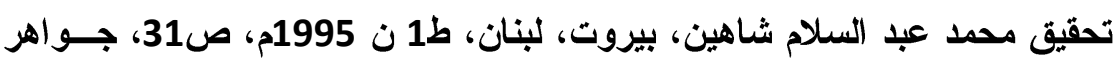

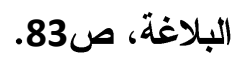
(169) لافتات أحمد مطر، لافتة رقم1، ص43، وانظر عـــ سـبيل المثــل ص451،50، $.64 ، 58$ (170) نفسه: لافتة رقم 1،ص155. 
(171)(بو القاسم محمود بن عمر الزمخشري"ت. 538هـ": المفصل في علم العربية، دار

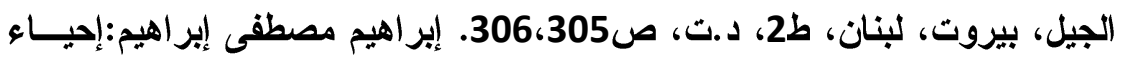
النحو، مطبعة لجنة التأليف والترجمة والنشر، القاهرة، 1951م، ص30. (172) لغة شعر الثريف الرضي، ص144)

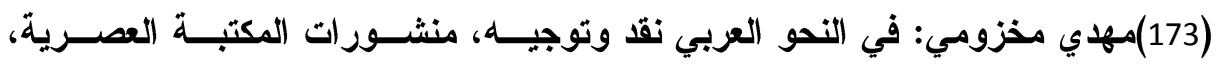

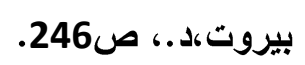

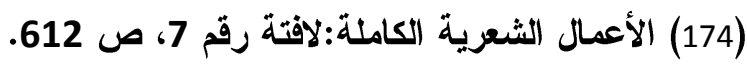

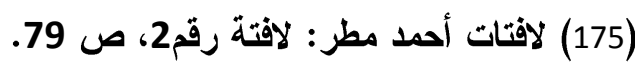

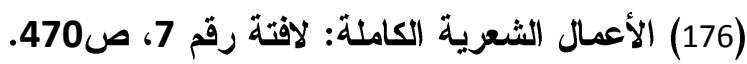

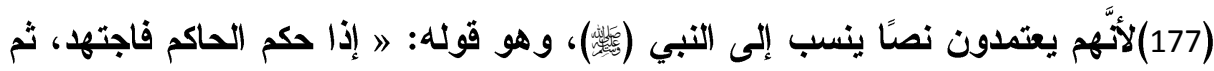

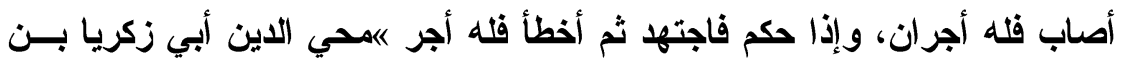

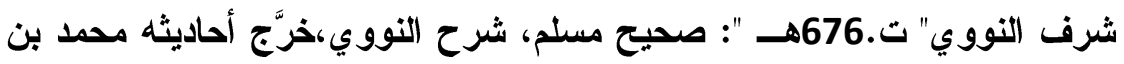

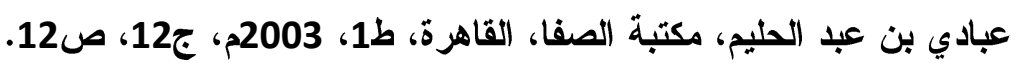

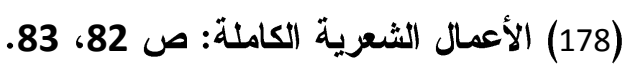

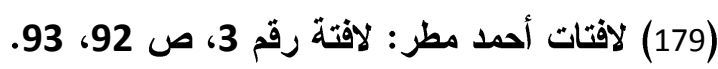

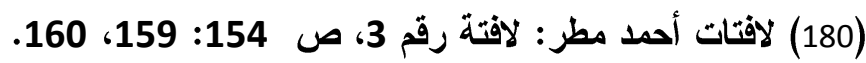

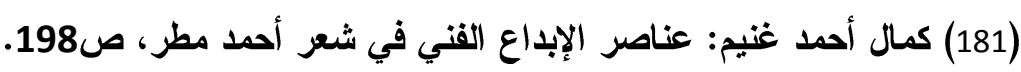

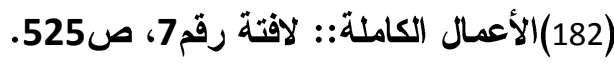

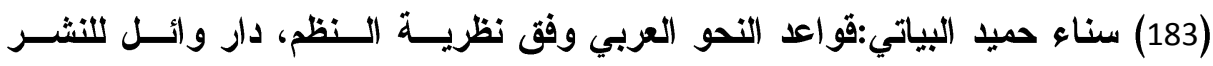

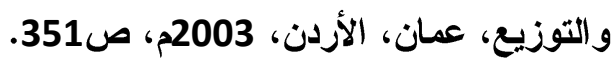

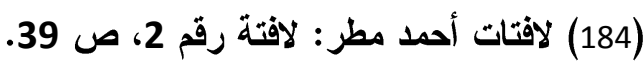

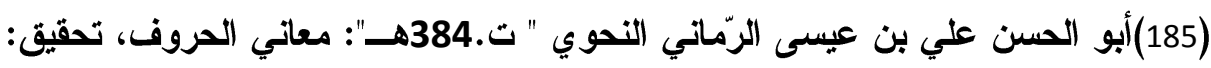

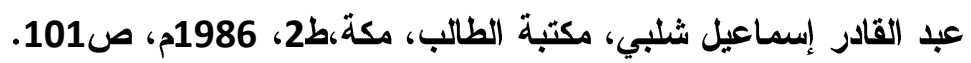

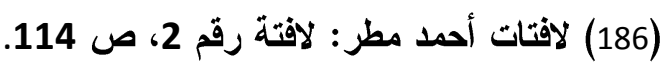

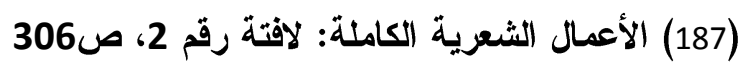

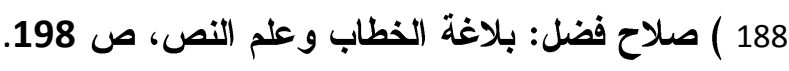


(189) بنية اللغة الثعرية، ص101، 102.

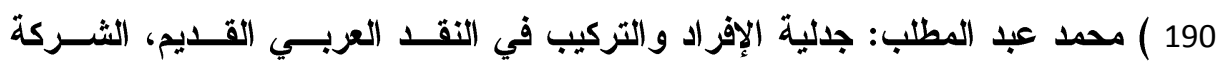

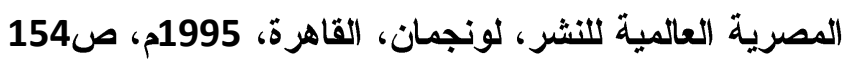

191 ) صلاح فضل: بلاغة الخطاب وعلم النص،ص 78. 192 ) محمد عبد المطلب: جلاية الإفراد والتركيب في النقد العربـي القـــيم، ص 161، .162

(193) عبد القاهر الجرجاني:دلائل الإعجاز، ص106، د. عبد الحكيم راضي: نظرية (للغة

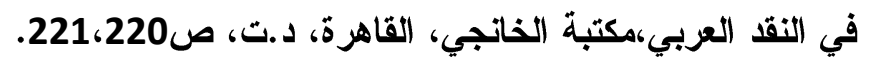
(194)أبو بشر بن عثمان " سيبويه": الكتاب، تحقيق عبد السلام محمد هـــارون، الهيئــة

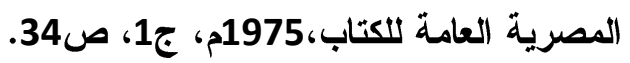

(195)د. صلاح فضل: علم الأسلوب، دار الشروق، بيروت، ط1، 1998م، ص218. فـــ الله أحمد سليمان: الأسلوبية، ص 10 10، 11.

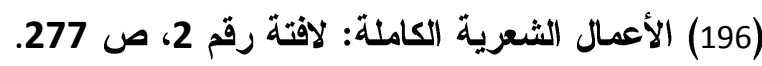
197 ) ينظر د. عبده الراجحي: التطبيق النحوي، مواضع التقديم والتأخير إذا كان الخبــر

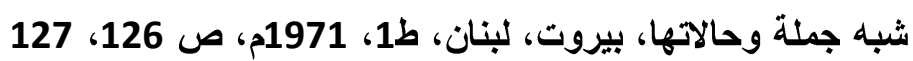

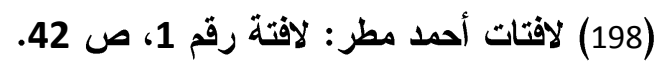

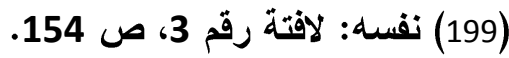
200 ) الأعمال (الكاملة: لافتة رقم 1، صل صل 255 201 )لافتات أحمد مطر: نفسه1، ص الاعب 55 (202) نفسه: ص47)

(203) الثريف المرتضي: الأمــالي،تحقيق محمـــ أبـــي الفضـل إبر اهيم،إيـران، ط1، 1384هــ، صن5.65.

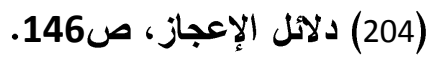
(205) ابن جني: الخصائص، تحقيق محمد علي النجار، الهيئة المصرية للكتاب،1999م، ص 362. (206)(الثريف الرضي: تلخيص البيان في مجازات القرآن، تحقيق محمد عبد الغني حسن، دار إحياء الكتب، 1955م، ص142.

doi: $10.12816 / 0010463$ 
(207) محمد عبد المطلب:قضايا الحداثة عند عبد القاهر الجرجاني، الثــركة المصــرية

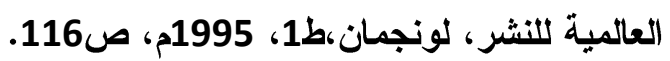

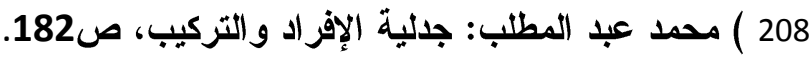

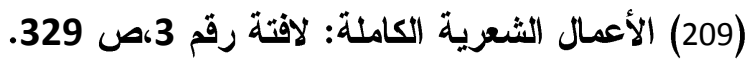

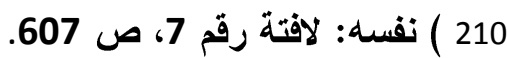

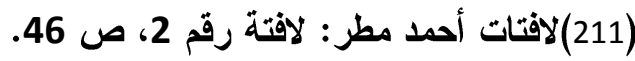

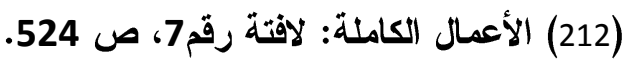

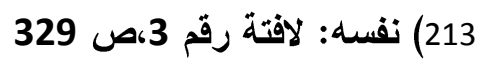

214 ) محمد بنيس: الثعر العربي الحديث، الثعر المعاصر؛ حيث أثثار إلى صيغ الحسـف

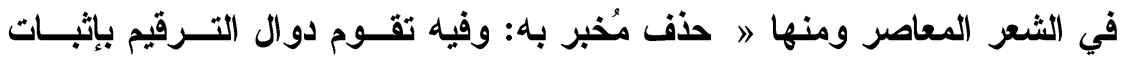
عنصر محذوف أو عناصر محذوفة. وبذلك تتلخل الدوال في بناء النص من خلا وفل

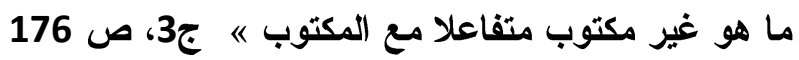

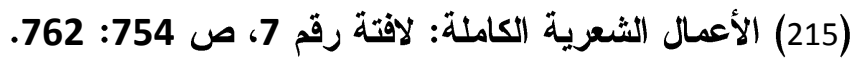

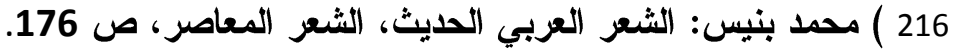

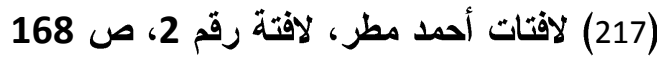

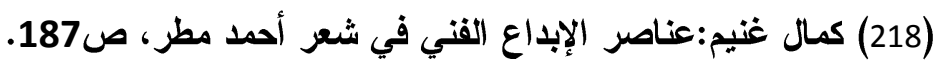

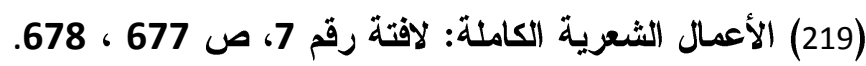

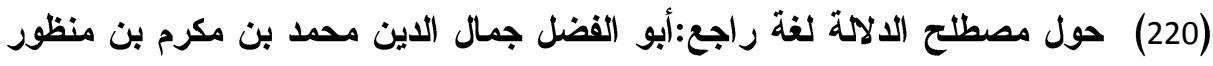

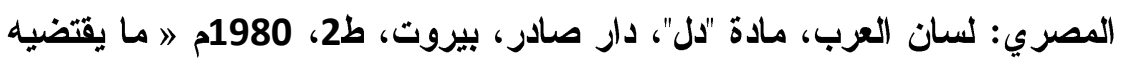

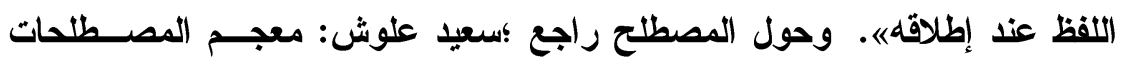
الأدبية المعاصرة، عرض وتفسبر ومقارنة،» مضمون الوحدات اللغوية المكونــة

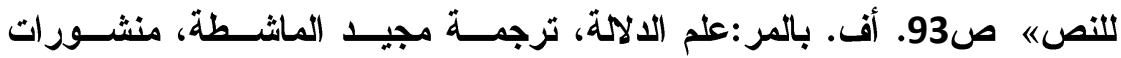

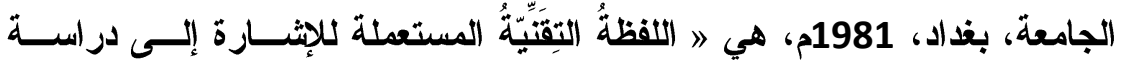

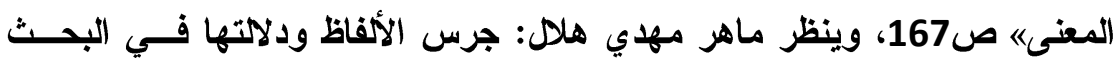
الدالاي والنقاي عند العرب، ص285. 
(221)نازك المـلانكة:سيكولوجية الثعر ومقالات أخرى، دار الثــؤون الثقافيـة، بغــداد، العراق، 1993م، ص17، ومحمد يونس:وصف اللغة العربية دلاليَّا، منشــورات جامعة الفاتح، ليبيا، 1973م، ص190،

(222) عمران الكبيسي:لغة الثعر العراقي المعاصر، وكالة المطبوعــات، الكويـــ، ط1،

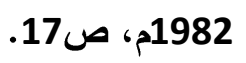

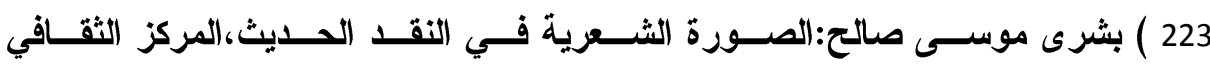

$$
\text { العربي،بيزوت، 1994م، ص } 12
$$

224 ) محمد حسن عبد الله: الصورة والبناء الثعري، دار المعارف، القــاهرة، 1981م،

$$
\text { ص19. }
$$

225 ) صلاح فضل: بلاغة الخطاب، وعلم النصا، راجع حديثه عن " سوسيير" و الصورة السمعية الأهنية، حديثه عن الصورة ومفاهيم الفكرة والإحساس والإرادة ص 14،

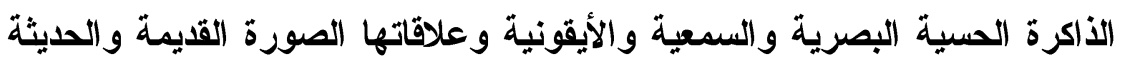

$$
\text { بالانطباعات ص 28، } 29
$$

226 )عبد الغفار مكاوي: قصيدة وصوره، يشير عبد الغقار مكاوي إلى أنه كان من نتـــاج

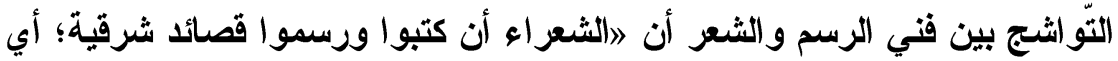

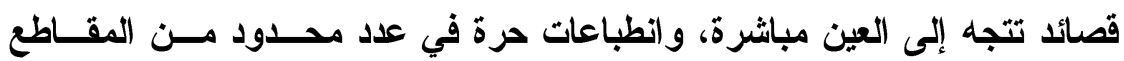
و السطور ،و إيحاءات مركزة عن طريق تمثل الطبيعة لا عن طريــق نســخها،و أبيات مقتصدة شديدة التركيز والإحكام من نوع الإبيجر ام.《، ص 13، 14. وكذا حـــيث

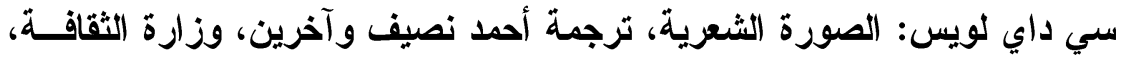

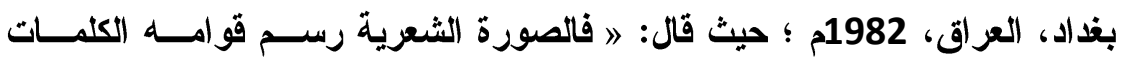

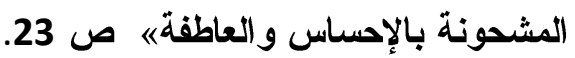
227 ) التعبير من واقع أحد إبيجرامات أحمد مطر بعنوان ( اصعد)، وجاء فيه ( حتى أنا/ وكل من حولي هنا/ في غربة (الغربة)، ص 207.

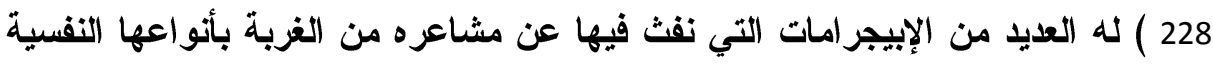
والمكانية؛ على سبيل المثل لا الحصر إبيجرام ( الغريب)، وجاء فيه ( غربة مسن غير حد/ غربة فيها الملايين/.غزبة موصولة / تبأ في المها / ولاعودة منهـا). 


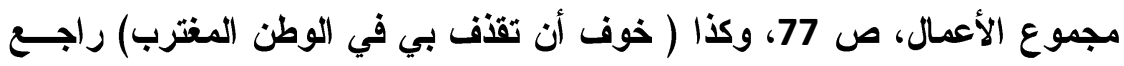

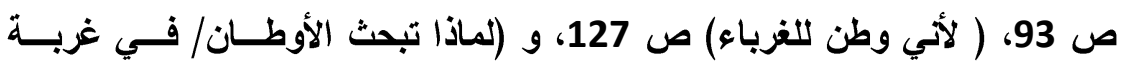
روحي عن وطن؟!) ص 342..إلخ.

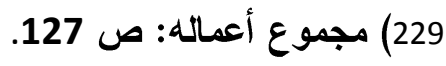

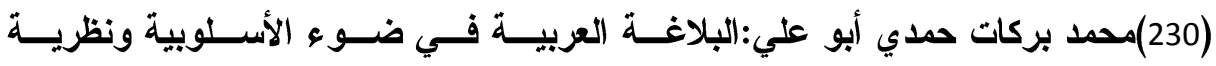

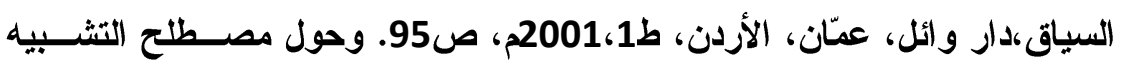

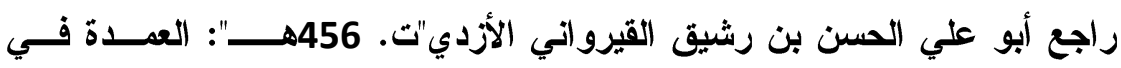

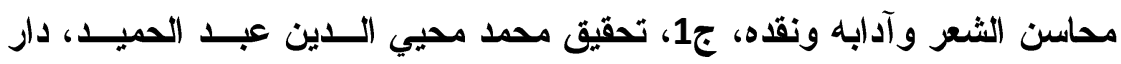

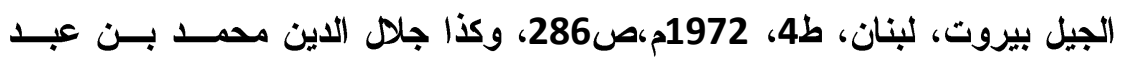

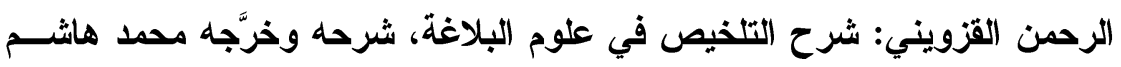

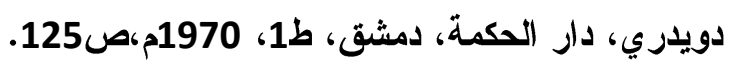

(231) جابر عصفور، الصورة الفنية في التراث النقاي والبلاغي، داري، دار المعارف، 1974م،

$$
\text { ص172. }
$$

(232) محد حسين علي الصغير:أصول البيان العربي،رؤية بلاغية معاصرة،دار الثؤون

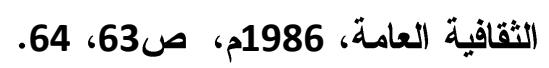

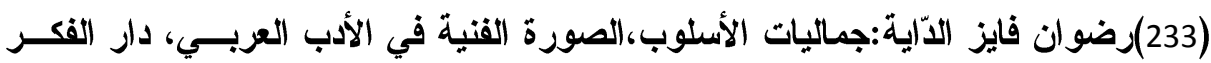

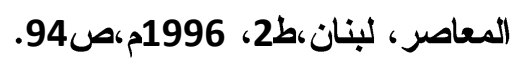

234 ) أحمد الصغير المراغي: بناء قصيدة الإبيجراما في الثعر العربي الحديث، الهيئــة

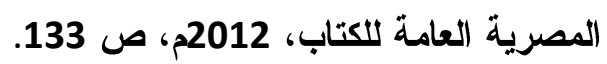

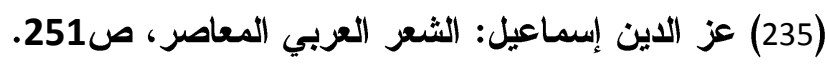

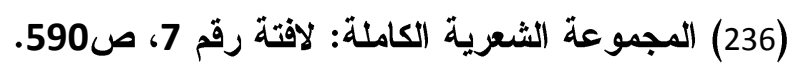

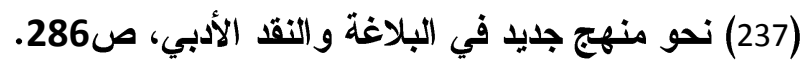

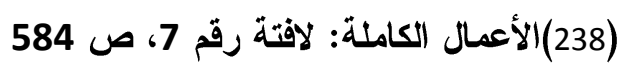

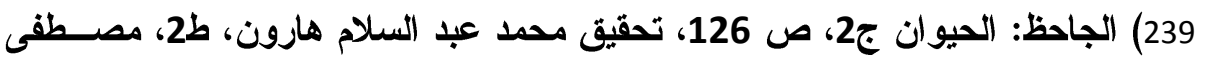
البابي الحلبي، 1950م. (240) نفسه: لاقتة رقم 1، ص272 البابي، 274 
(241) لافتات أحمد مطر : لافتة رقم 4، ص58. (242)د.علوش:معجم مصطلحات الأدب، ص3153، جاكوب كورك: اللغة في الأدب الحديث،

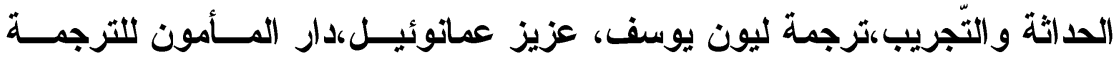

$$
\text { و النشر ،بغداد، 1989م، ص252. }
$$

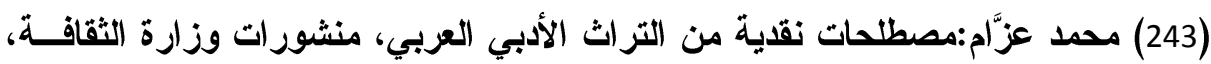
سوريا،ط1، 1995م، ص36، حسين خمري:الظاهرة الشعرية العربيــة الحضــور

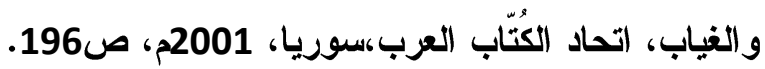

(244) جابر عصفور:الصورة الفنية في التراث النقدي والبلاغي، ص247، وعبد القـادر

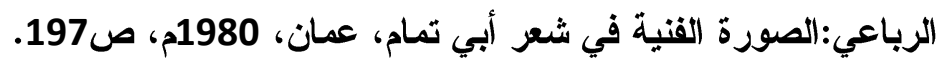

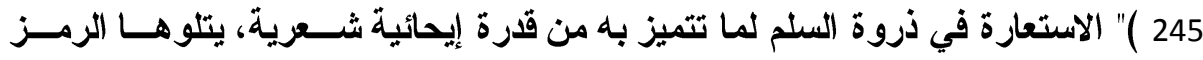
لاعتماده على الصورة الأهنية، ويأتي بعدهما التثــبيه " صــلاح فضــل بـل بلاغــة

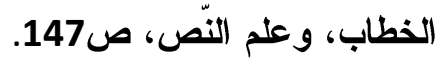
(246) سناء حميا العبيدي:نحو منهج جديد في البلاغة و النقد الأدبي، ص293. (247)مصطفى الشكعة: فنون الثعر في مجتمع الحمدانيين، عالم الكتب،بيروت، 1981م، ص ص

(248) إليز ابيث دور: الثعر كيف نفهمه ونتنوقه، ص61.

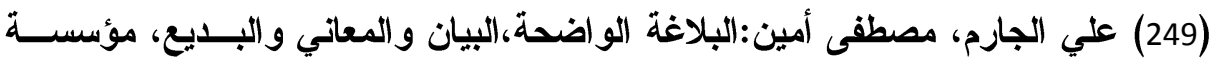

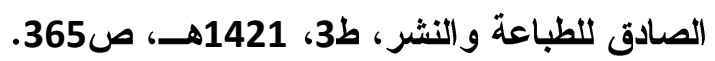

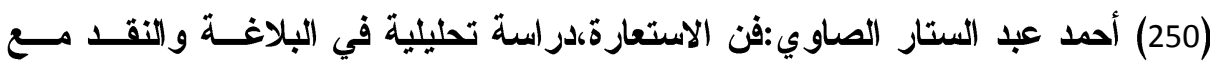

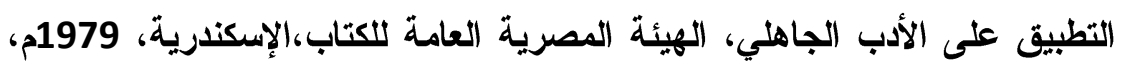

(251) المجموعة الشعرية الكاملة، ص201. 252 ) نفسه: لافتة رقم 75 (251) ص 571

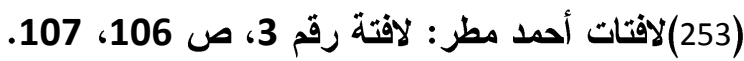
(254) نفسه: لافتة رقم 2، ص139.

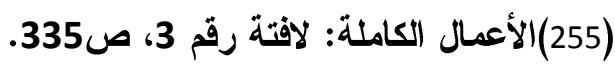




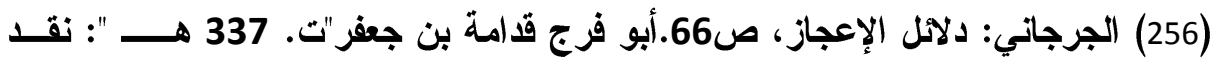

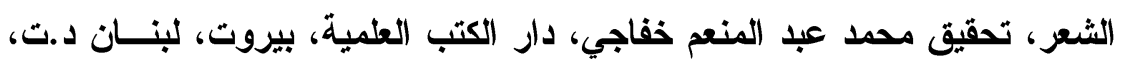

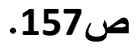

(257) عبد الحكيم راضي:نظرية اللغة في النقد العربي، ص236.

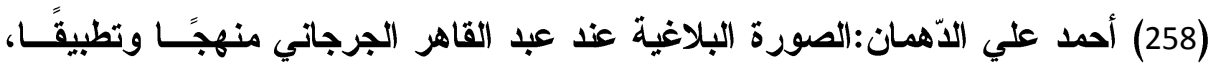

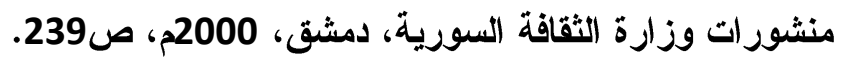

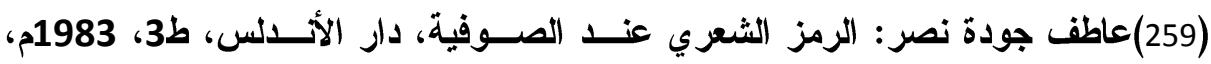
ص 504. (260) المجموعة الثعرية الكاملة: ص106.

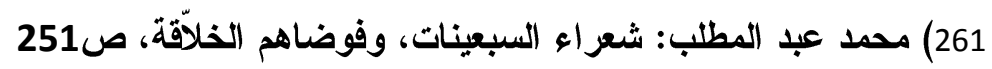
262 ) هذه المعالجة للفقر وحجمه في هذا الإبيجرام تتناص معنويًا وفنيًا على نحو كبيـر مع أبيات أبي الشمقمق تُوفي 200 هـ أحد الشعراء الذين يمثلون النزعة الشعبية

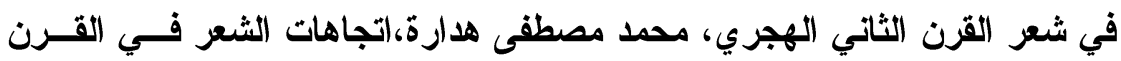

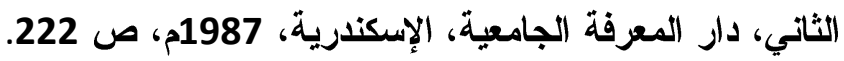
(263)الأعمال الكاملة: 101، 102. (264) نفسه: لافتة رقم 4، ص 80. 265 ) نفسه: لافتة رقم 3، ص 108. 266 )نفسه: لافتة رقم1، ص الص 113.

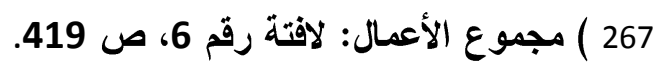
268 )نفسه: لافتة رقم 7، ص (269) نفسه: لافتة رقم7، ص670. (270)نفسه: لافتة رقم7، ص 630.

(271) Mohammadi, H., time in the wildeness, transAndintro, by ( 271 M. Enani, General Egyptian Book Organization Cairo, 2000, p. 8 272 ) أحمد الصغير: بناء قصيدة الإبيجرام في الثعر العربي الحديث اوانلافت للنظــر أن

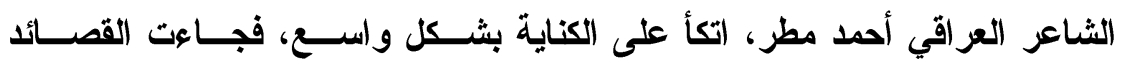
القصيرة (الإبيجر امات) مشحونة بالكنايات «، ص عل 145. 
(273)محمد سعد شحاته، العلاقات النحوية وتثكيل الصورية الثعرية عند محمد عفيفـي مطر، الويئة العامة لقصور الثقافة، 2003م، ص220.

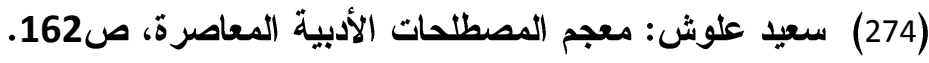

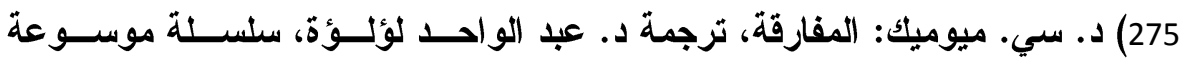
المصطلح النقدي، وزارة الثقافة و الاعلام،بغداد 1982م،صد 11 11، 12.

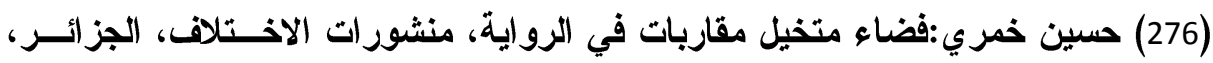
ط1، 2002م، ص156.

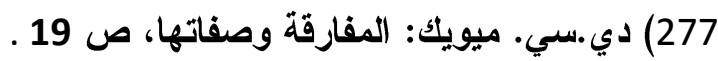
(278)عبد الله الطيب المجذوب:المرشد إلى فهم أشعار العرب وصــناعتها، ج2، مطبعـة

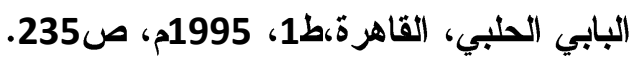

279) أبو العباس أحمد بن يحي ثعلب"ت.291هـــ قواعد الثعر، تحقيق رمضــــان عبــــ

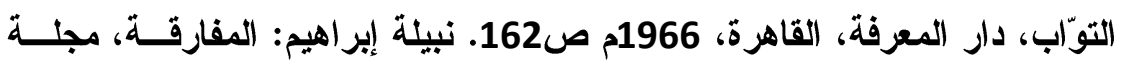

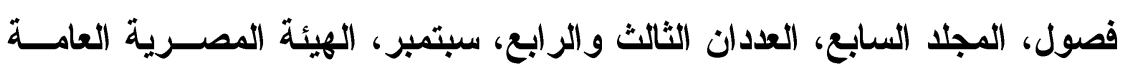
للاكتاب، 1987م، ص صدمان 133.

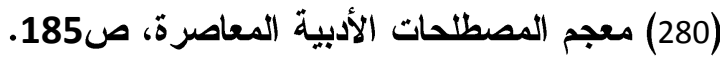
(281) دي. سي.ميونك: موسوعة المصطلح النقدي (المفارقة)، ص185. 282) نبيلة إبر اهيم:المفارقة،صئ133. (283) المجموعة الشعرية الكاملة: ص868 284 ) سبق أن نوهت عنها،و المصطلح للأستاذ محمد عناني: 8 أنها:

Time In The Wildeness, Transandintro p. 8 285) كمال غنيم:عناصر الإبداع الفني في شعر أحمد مطر،ص239.و للاكتور محمد عبـــ

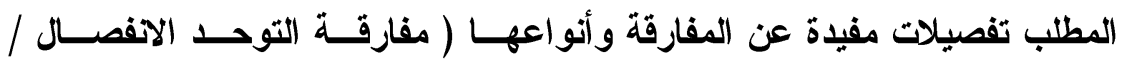

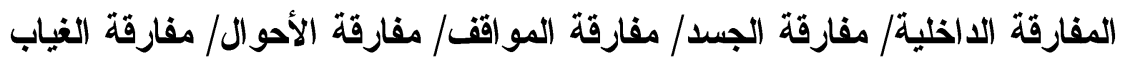
والحضور)،مبحث: قراءة المسكوت عنه في نص ميسون صــر (رجل مجنـون لا يحبني)، في كتابه شعراء السبعينيات وفوضاهم الخلاّةة، ص 252: 254

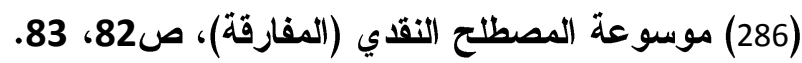
287 ) لافتتات أحمد مطر : لافتة رقم 7، ص صد 
(288) موسوعة المصطلح النقدي (المفارقة)، ص90. أحمد غنيـــــم، كمـال:عناصـر

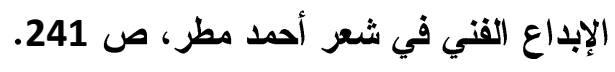
(289) لافتات أحمد مطر: لافتة رقم 5، ص 162.

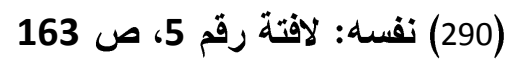

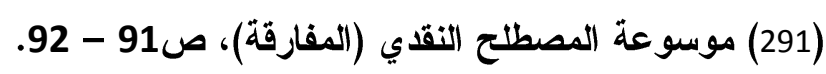

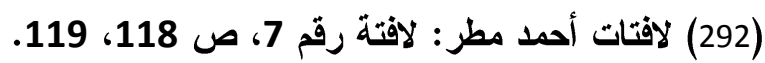

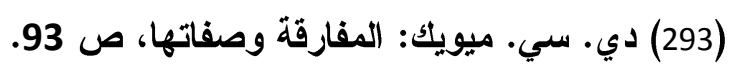

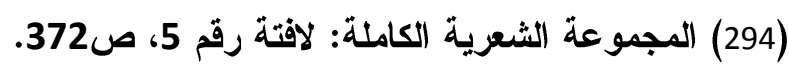
295 ) يوسف نوفل: طائر الثعر، عش الفيض.. فضاء التأويل، ص238.

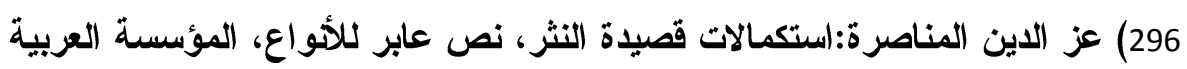
للار اسات و النشر، بيروت، لبنان، ط2، لانئ 2002م، ص 289. 297 ) أوين كرزويل: عصر البنيوية من ليفي شتراوس إلى فوكو، ترجمة جابر عصفور،

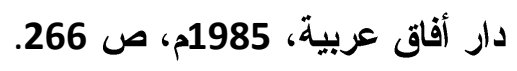

298 ) جوليا كرستيفا:علم النَّصه النصوص تتم صناعتها عبر (متصاص م - وفي الوقـت

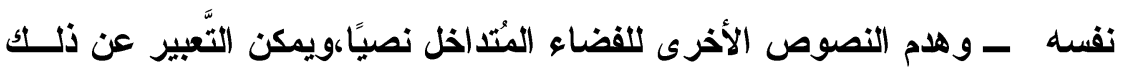
بأنها تر ابطات متتاظرة...ذات طابع خطابي «، ص 79.

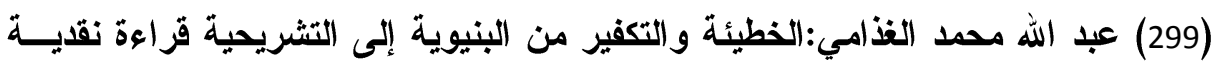

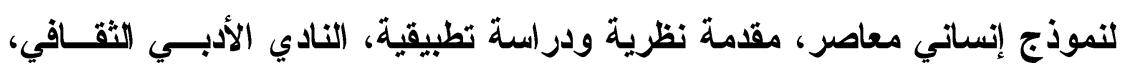

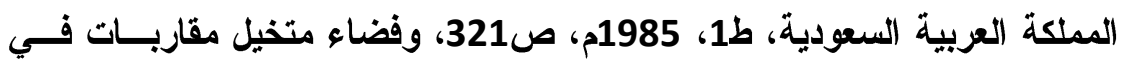

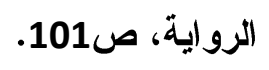

(300)نظرية النص، رولان بارت، ترجمة: د. محمد خير البقاعي، مجلة العــرب والفكـر

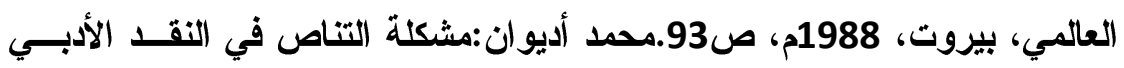

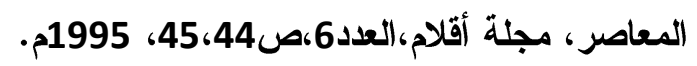
(301) السابق: ص93. (302) صبري حافظ:أفق الخطاب النقدي،در اسات نظرية وقراعات تطبيقية،دار شــرقيات،

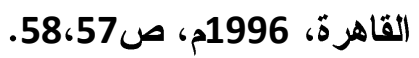


(303) محمد مفتاح:تحليل الخطــاب الثــعري (إســتراتيجية التـــاص)،المركز الثتــافي

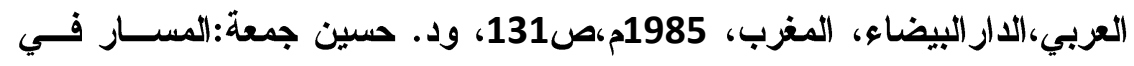

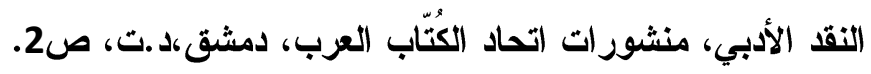

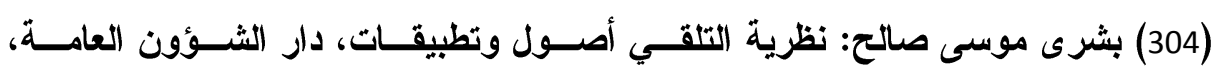

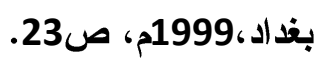

(305) أحمد نـاهم: التناص في شعر الرواد، دار الشؤون العامــة، بغــداد، ط1، 2004م،

$$
\text { ص }
$$

(306) محمد بنيس:ظاهرة الثعر المعاصر في المغرب مقاربة بنيوية تكوينيــة، ص253.

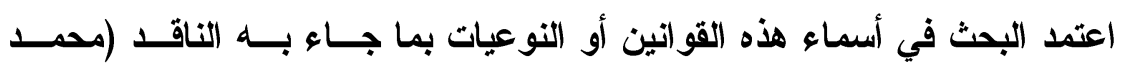

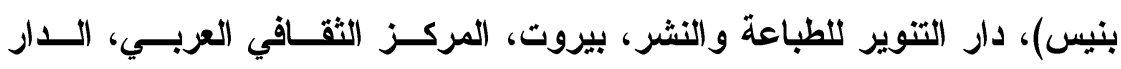

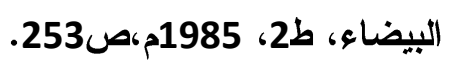

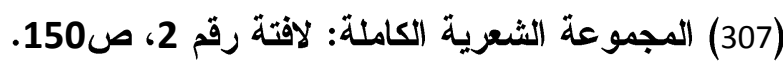

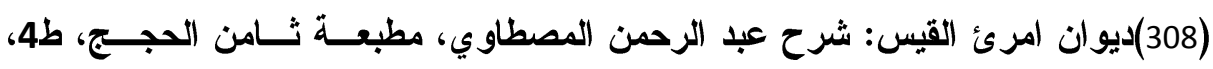

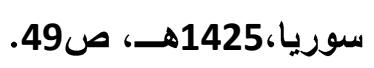

(309) ظاهرة الشعر المعاصر في المغرب مقاربة بنيوية تكوينية، ص253.

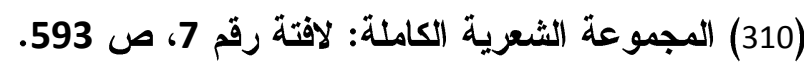
(311) سورة مريم، الآية (310) (25).

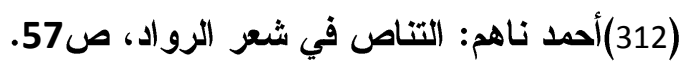

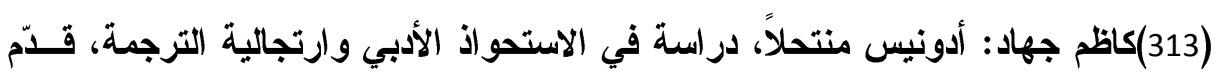

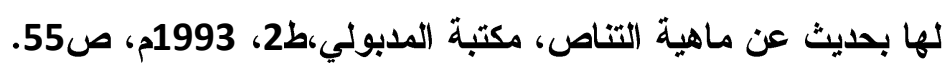

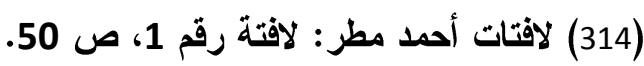

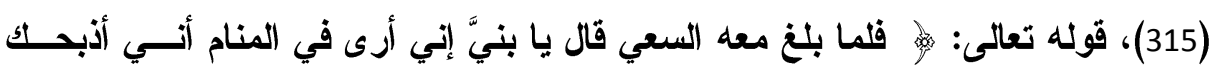

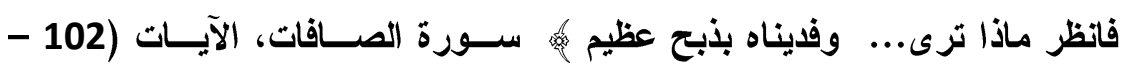


316 ) ثمة بحث ق قام على دراسة مظاهر التناص الايني في شعر أحمد مطـر، للباحـث

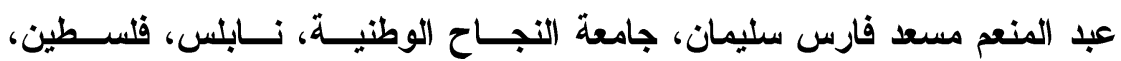
.2005

(317) المجموعة الثعرية الكاملة: لافتة رقم 1، ص صن 256.

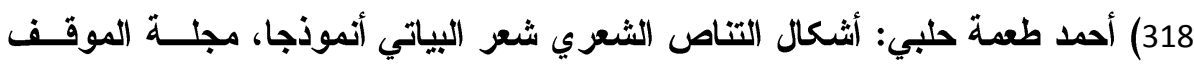

$$
\begin{aligned}
& \text { الأبي، اتحاد الكتاب العــرب، دمشث، العدد 430، فبراير } 2007 . \\
& \text { (319) سورة المسد، الآيات (1 - 2 2). }
\end{aligned}
$$

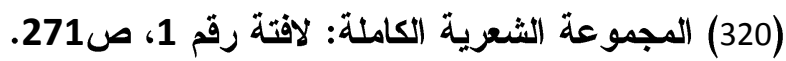
(321) سورة الكهف، الآية (320) (10).

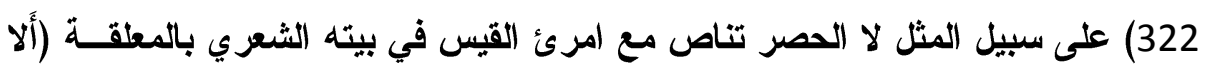

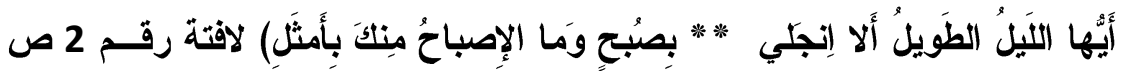
150، وتتاص مع سحيم الرياحي الثاعر المخضرم في بيته المشهور (أَنا إِنُ جَلا

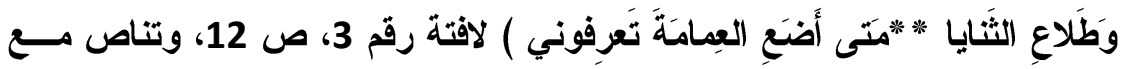

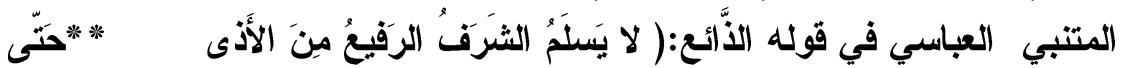

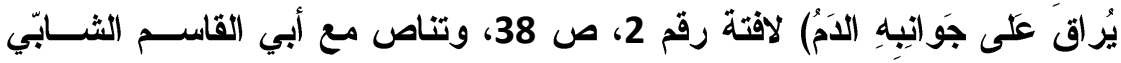

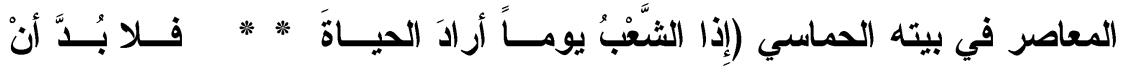

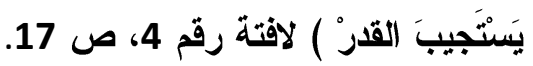

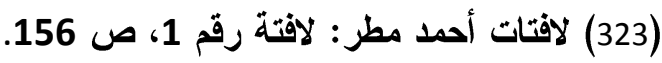

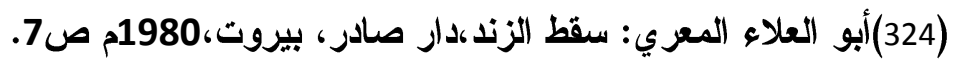

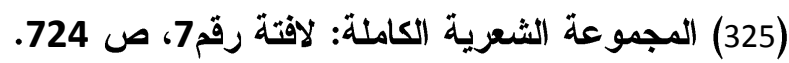
(326)أبو جعفر محمد بن جرير الطبري:تاريخ الرسل والملوك، ج2، تحقيق محمــــ أبــي الفضل إبر اهيم، دار المعارف، القاهرة، ط4، 1965م. ومفادها أنهـــاكانــت بــين أهل المدينة من طرف ويزيد بن معاوية والأمويين من طرف آخر ، واتتهت بمقتـلـل عــد

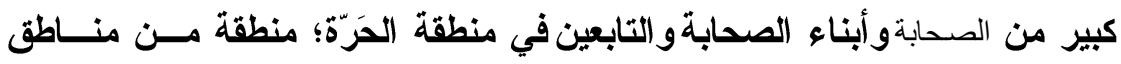

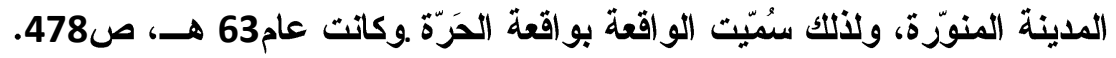




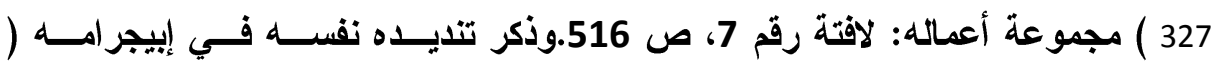

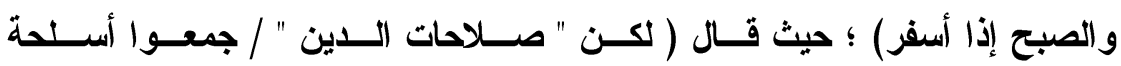

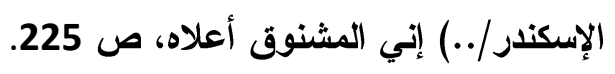

(328) القزويني: الإيضاح في علوم البلاغة، البيان والمعاني والبديع، مكتبـــة النهضـــة، بذاد، ص353.

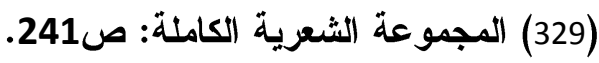

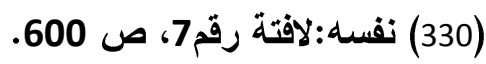

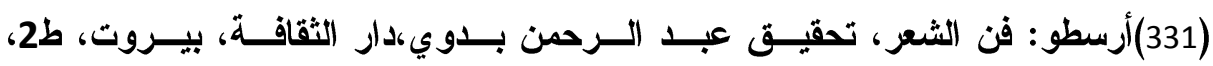

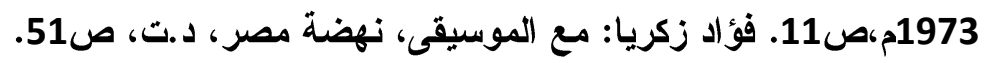

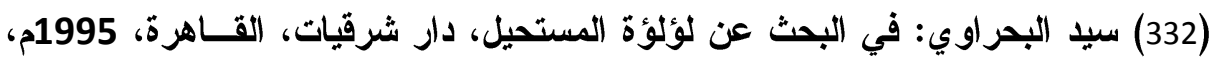
ص.57.

(333) شكري الطو انسي: مستوى البناء الثعري عند محمد إبراهيم أبــي ســنة، الهيئــة

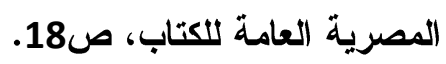

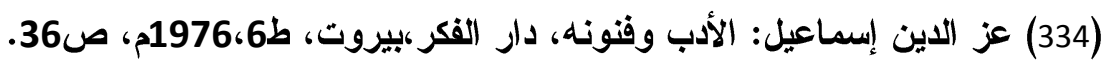

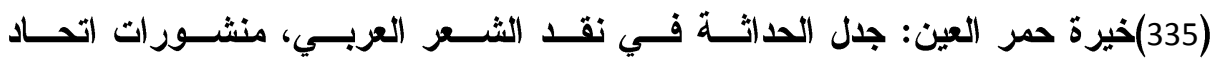

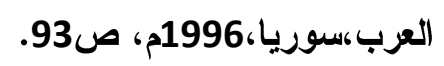

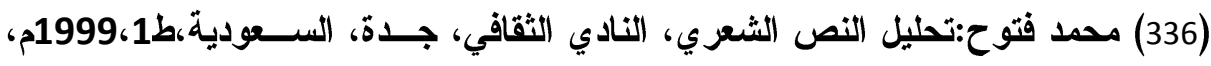

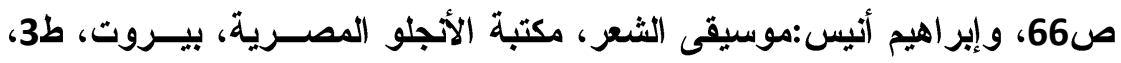

$$
\text { 1965م، ص13، وإير الميم }
$$

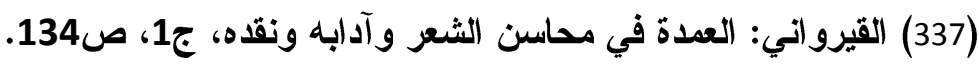

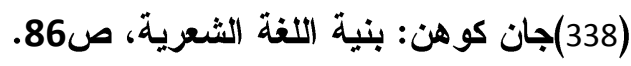

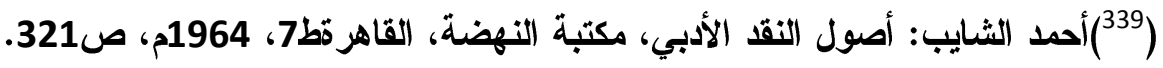
(340) جهاد فاضل، قضايا الثعر الحديث، دار الثروق، بيروت، ط1، بـ، بيروت، ط1، 1984، ص62.

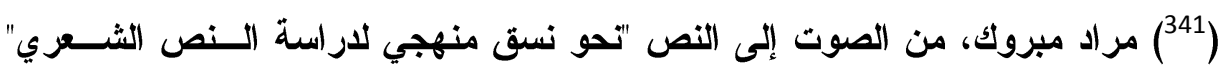

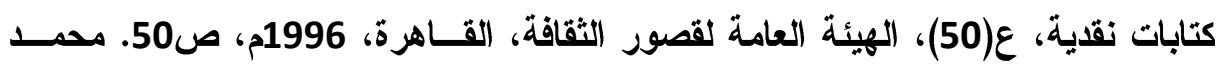


الهادي الطر ابلسي: في مفهوم الإيقاع، حوليات الجامعسة التونسـية، عـدد32، 1991م، ص 21. (342) محيي الاين اللاذقاني، القصيدة الحرة (معضلاتها القنية وشرعيتها التراثية) فصول،

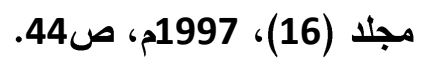
(133) صلاح فضل: أساليب الشعرية العربية المعاصرة، سلسلة كتابــات نقديـة، ع ع (54)،

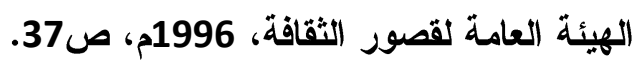

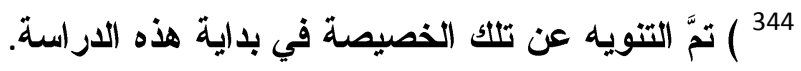

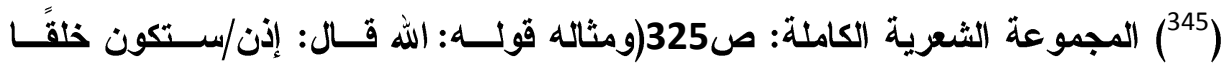

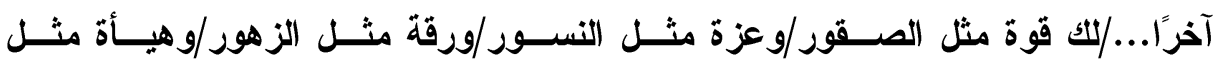

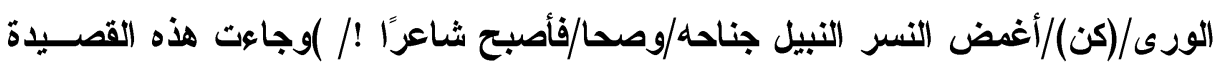
على الضرب الصحيح، وأتت كذلك بتشكيلتين ؛ التامة (متفاعلن) والمضمرة (متفــاعلن).

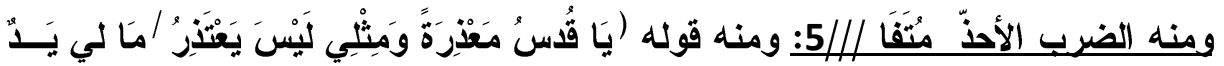

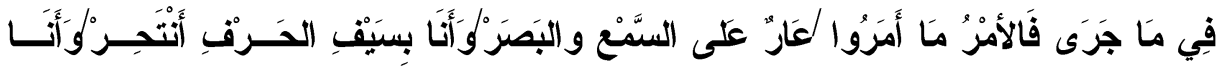

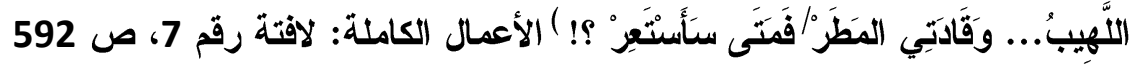

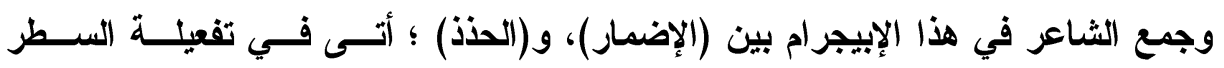

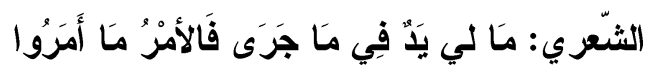
$5 / / /-5 / / 5 / 5 /-5 / / 5 / 5 /-5 / / 5 / 5 /$

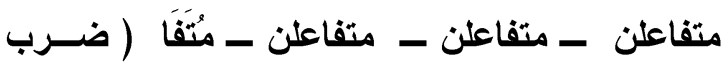

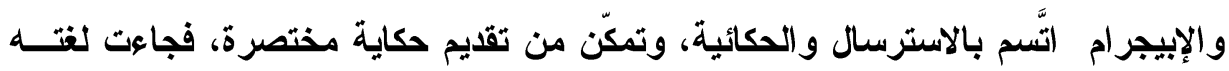

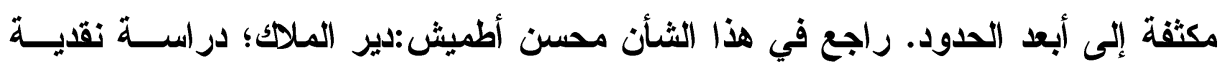

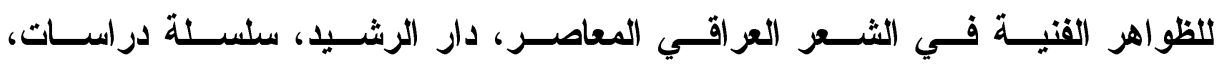
$.22 ، 21$ (1982 1982

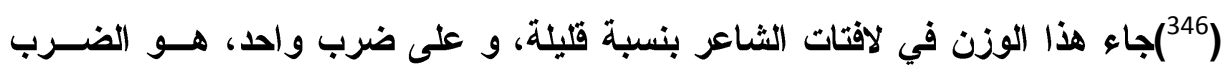

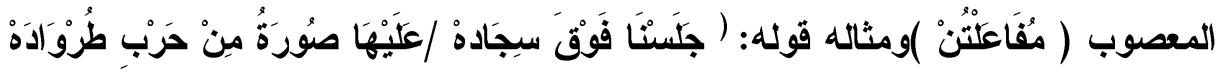

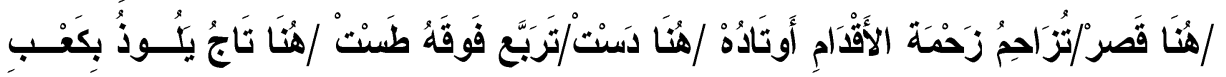




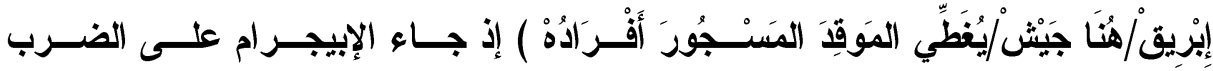

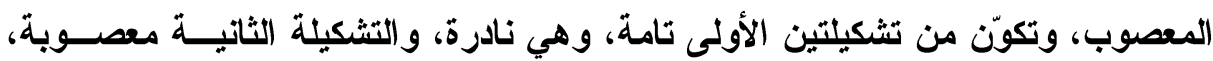

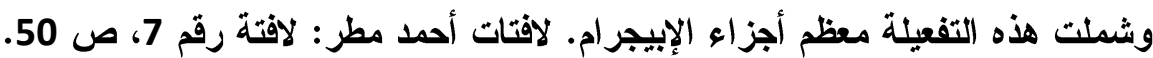

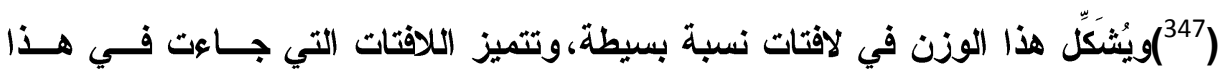

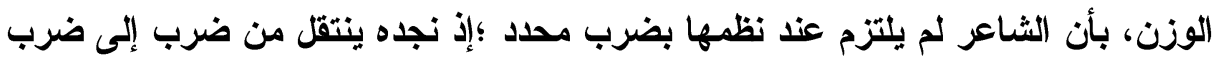

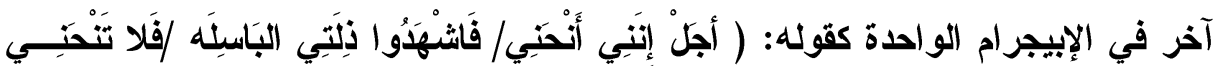

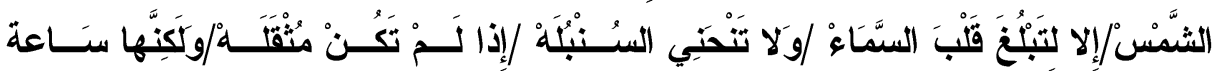

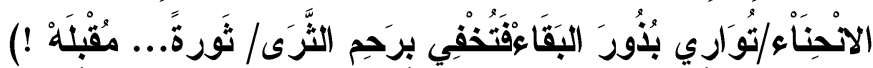

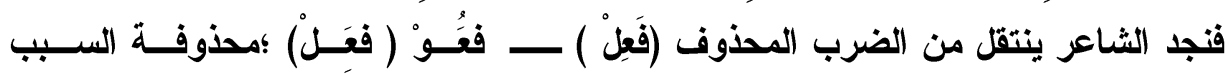
أَجَلْ إِنَنِي أَنْنَبِي الخفيف الأخير (لُنْ) كما في السطر الأول:

$$
\begin{aligned}
& \text {.5// - 5/5// - 5/5// } \\
& \text { فعولن - فعولن - فَعَوُ ( فَعِلْ) }
\end{aligned}
$$

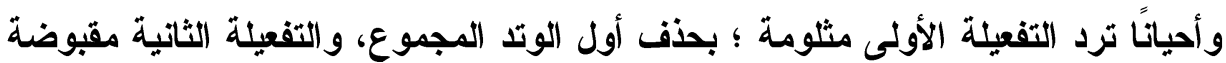

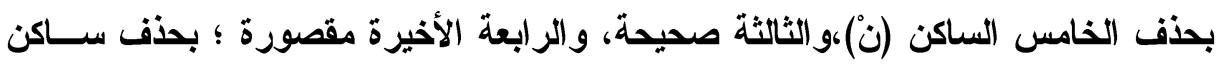

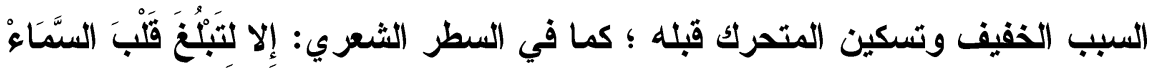

$$
\text { .55//-5/5//- /5// - 5/5/ }
$$

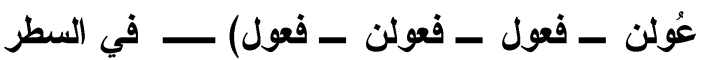

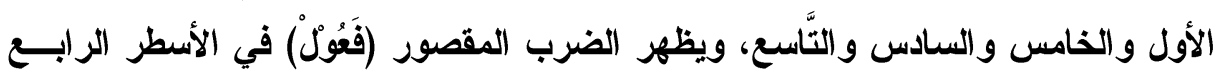

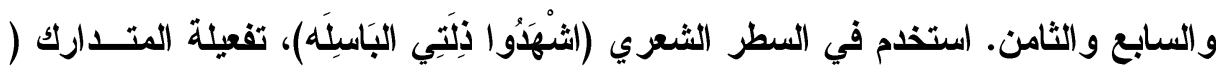

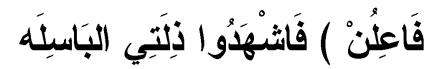

$$
\text { فاعلن - فاعلن - فاعلن - 5//5/5/ }
$$

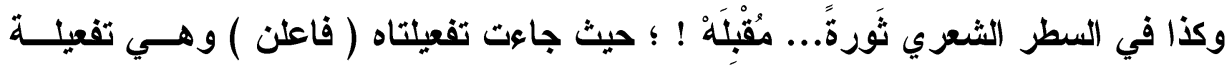

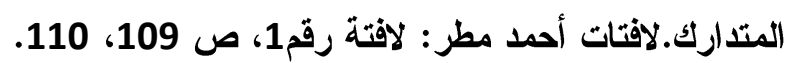

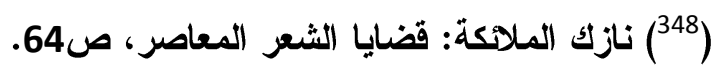

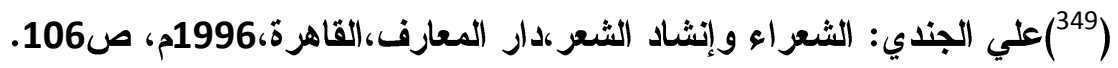


(150) (أبو الفتح عثمان بن جني: كتاب العروض، تحقيق أحمد فوزي الهيب، دار القلم للنشر و التوزيع، الكويت، ط1، 1987م،ص106، 107، وصفاء خلوصي:فن التقطيع الشــعري

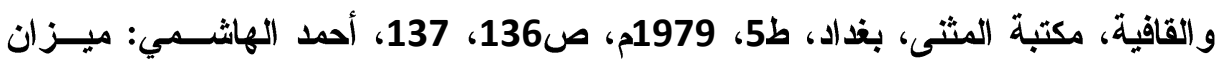

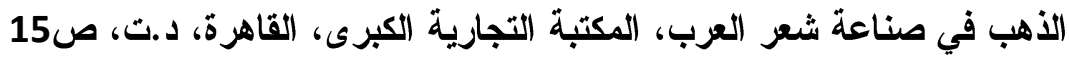
(351)د: صفاء خلوصي: فن التقطيع الشعري و القاقية، ص133.

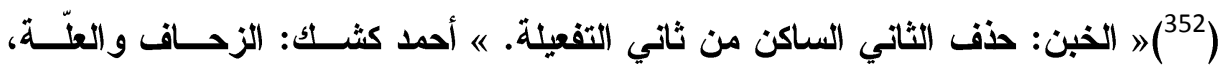
ص 29

(353)(النعمان القاضي: شعر التفعيلة والتراث، دار الثقافة، القاهرة،1977م، ص30.

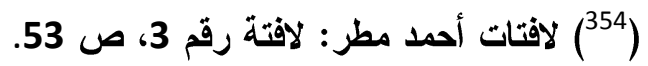

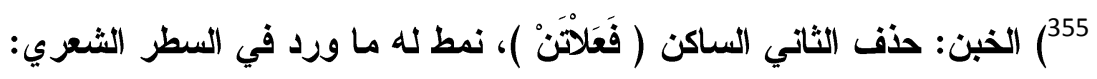
ادع للحكام بالنصر علينا

$$
\begin{aligned}
& \text {.5/5/// - 5/5//5/ - 5/5//5/ } \\
& \text { فاعلاتن - فاعلاتن - فَعلاتنْ }
\end{aligned}
$$

356) علة التَّبيغ: زيادة حرف ساكن على ما آخره سبب خفيف ( /5 ) ؛ نمط للخـبن "'"

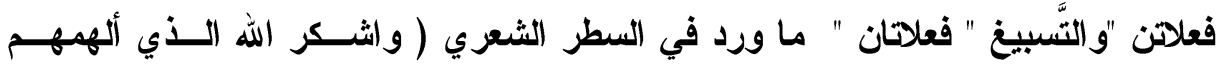

$$
\begin{aligned}
& \text {.55/5/// - 5/5/// - 5/5//5/ - 5/5//5/ } \\
& \text { فاعلاتن - فاعلاتن - فعلاتن - فعِلاتان. }
\end{aligned}
$$

موهبة (القمع )

357) الضرب المقصورة: حذف ساكن السبب الخفيف، وتسكين ما قبله ؛ نمط للمقصورة

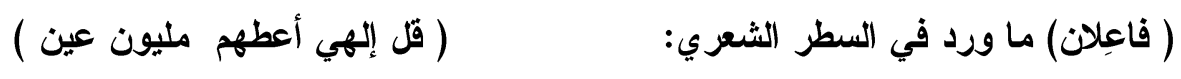

$$
\begin{aligned}
& \text {.55//5/ - 5/5//5/ - 5/5//5/ } \\
& \text { فاعلاتن - فاعلاتن - فَاعِلانْ. }
\end{aligned}
$$

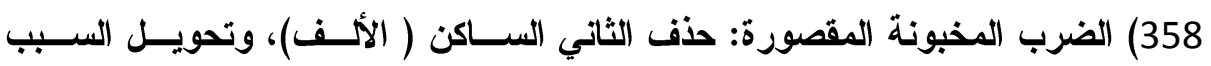
الخفيف الأخير إلى ساكن ( فَعِلانْ)، نمط لها ما ورد في السطر الشعري:

$$
\text { أعطهم ألف ذراع }
$$




$$
\text { فاعلاتن - فَ فَعِلانْ }
$$

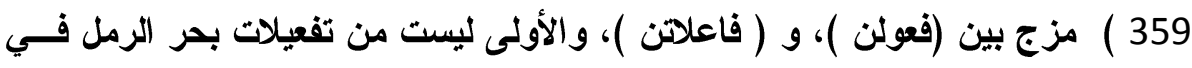

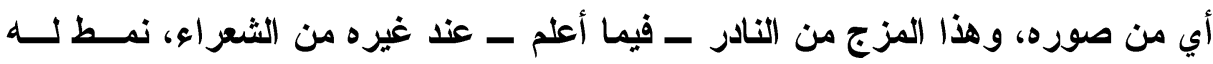
ماورد في السطر الثعري: و إبداع الكمائن

$$
\begin{aligned}
& \text {.5/5//5/ - 5/5// } \\
& \text { فعولن - فاعلانن. } \\
& \text { (360) لافتات أحمد مطر: لافتة رقم 4، ص } 84
\end{aligned}
$$

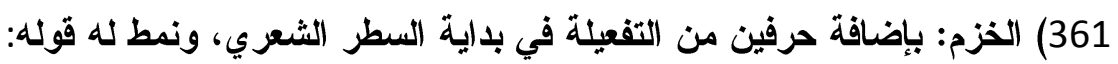

$$
\text { إلا شرارات الأماني ومصابيح اليقين }
$$

$$
\begin{aligned}
& \text {.55//5/ - 5/5/// - 5/5//5/ - 5/5//5/ - 5/ } \\
& \text { فا ـ فاعلاتن ـ فاعلاتن ـ فعلاهن - فاعلان. }
\end{aligned}
$$

362) ملحوظة قد يداخل هذا الضرب المدذوف الخبن ؛ مثل قوله: (زم عينيه وأبدى أسفه فُ فاعلن

$$
\begin{aligned}
& \text { 5/// - 5/5//5/ - 5/5//5/ } \\
& \text { فاعلاهن - فاعلاهن - فَعِلْن. } \\
& \text { وكذا في قوله: يا صديقي العربي. ( فاعلاتن - فَعَلُنْ ). }
\end{aligned}
$$

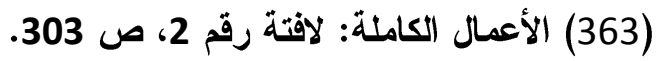

(364)ولهذا الوزن خمس أعاريض، وسبعة أضرب. صفاء خلوصي: فن التهب التقيع الثعري

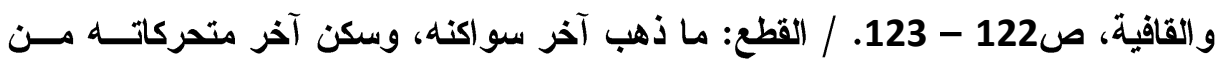

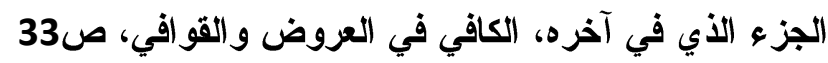

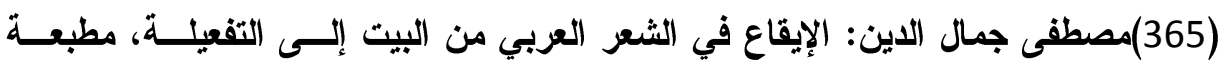

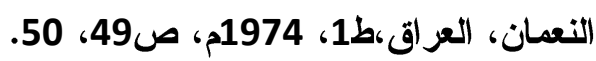

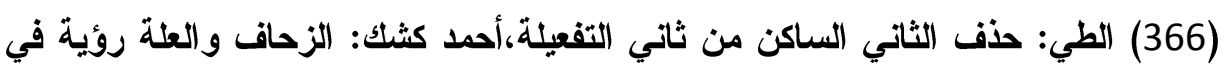

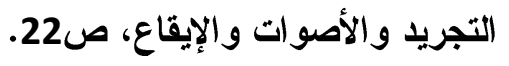


367) للوقوف على هذه الأنماط قا يتطلب الأمر دراسة مستقلة عن الإيقاع في شعر أحمد

مطر

(368)لافتات أحمد مطر : لافتة رقم 1، ص 131.

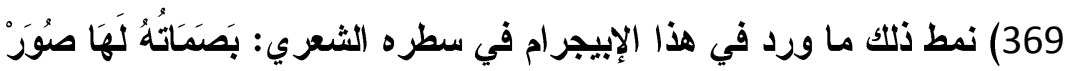

$5 / / 5 / /-5 / / 5 / / /$

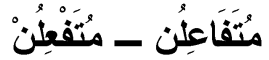

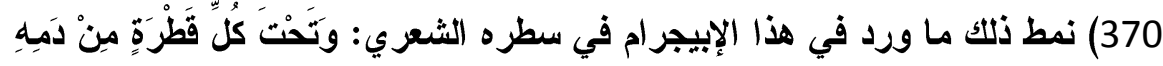

$5 / / 5 /-5 / / 5 / /-5 / / 5 / /$

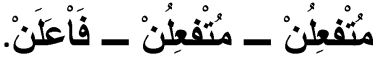

(371) لافتات أحمد مطر : لافتة رقم 6، ص 84.

(372) الخبن: علة غير لازمة، ولكن التزام الثاعر بها في أضرب القصيدة كافــة وفــي قصائد أخرى جعلت الباحثة تعدها إحدى الأضرب التي استعملها الشاعر.

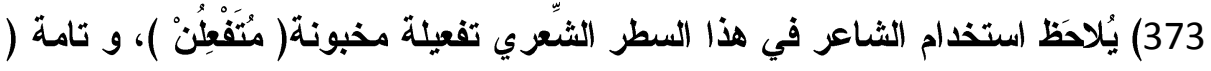

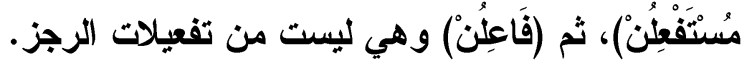

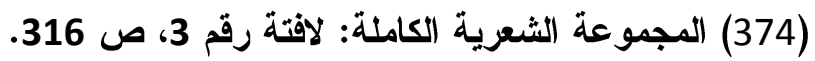

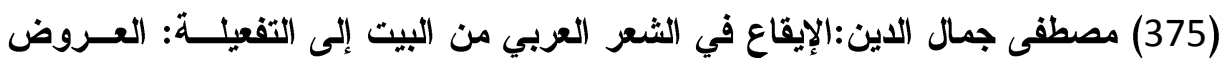

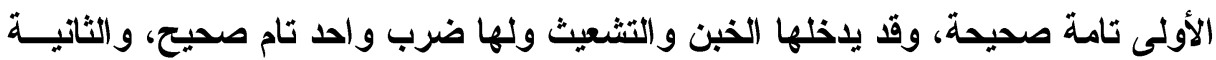

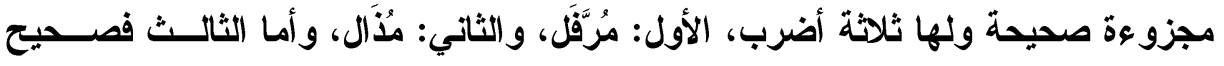

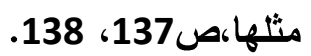

(376)محمد كنوني: اللغة الثعرية دراسة في شعر حميد ســعيد، دار الثــؤون العامــة، 1997م،ص262. 377) في هذا النَّص الإبيجر امي يتضح لنا أن بحر الرّمل يتداخل تداخلاً شديدًا مـــع بحـر

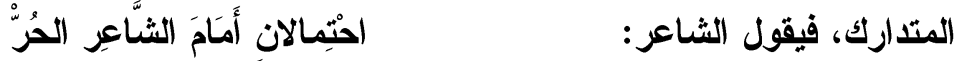

$$
\begin{aligned}
& 5 / 5 / / 5 /-5 / 5 / / /-5 / 5 / / 5 / \\
& \text { فاعلاتن - فعلاتن - فاعلاتن }
\end{aligned}
$$

(فاعلاتن) التفعيلة الأولى مُرَّلة بزيادة سبب خفيف ( /5) آخر التفعيلة 
بنية قصيدة الإبيجرام في لافتات أحمد مطرد. أسماء محمود شمس الدين

( فعلاهن) التفعيلة الثانية مخبونة مرُقفلَة بحذف الثاني الساكن وزيادة سبب خفيـف آخــر التفعيلة

( فاعلاتن) التفعيلة الثالثة مرُقَّةَة.

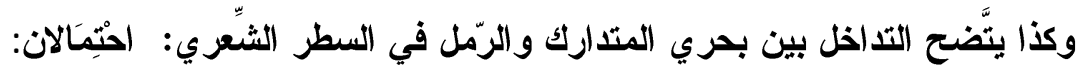
55/5//5/

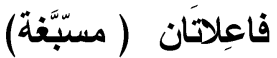

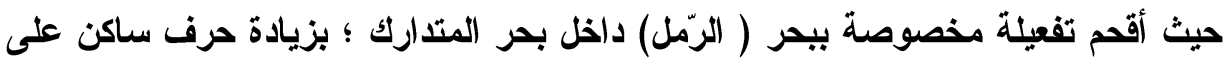

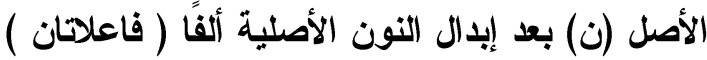

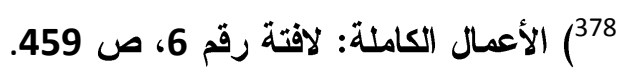

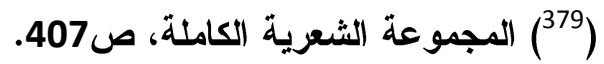

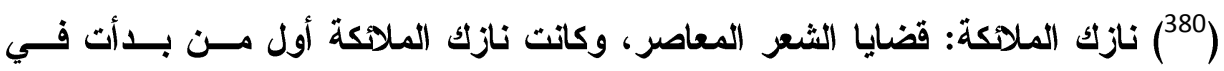

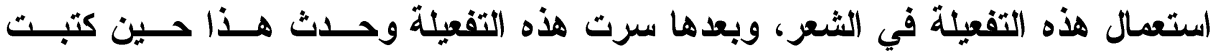
قصيدتها الكوليرا، صهائ134، 135. وانظرمحمد إحسان النص: روئية نازك الملانكة لقضايا

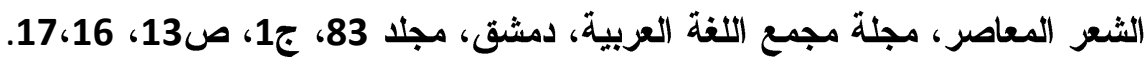

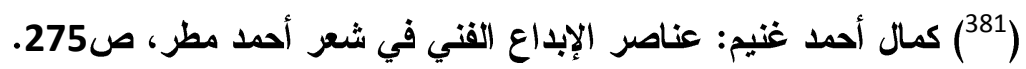

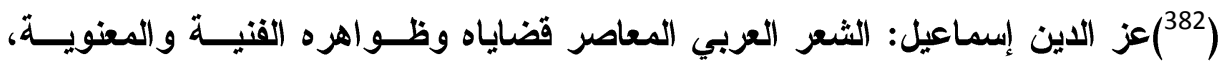
ص121. (121. n

(183) سي.موريه:حركات التجديد في موسيقى الثعر العربي، ترجمة سعيد مصلوح، عالم

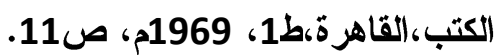

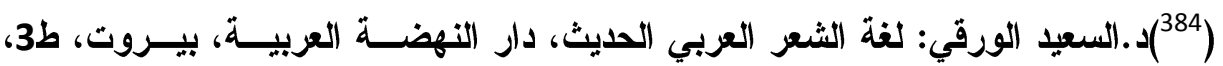

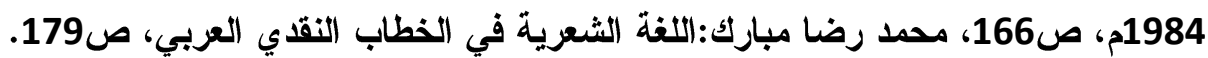

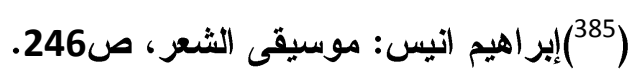

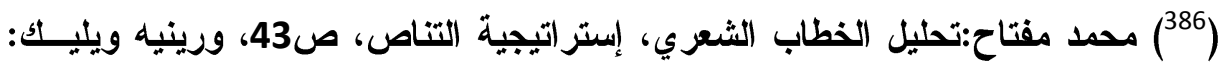

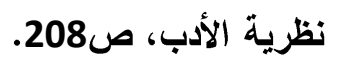

(387) إليز ابيث دور: الثعر كيف نفهمه ونتذوقه، ص45.

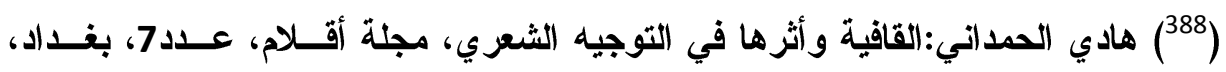
1968م، ص178. 
( ) محمد صابر عبيد: القصبدة العربية الحديثة بين البنية الالاية والبنيــة الإيقاعيــة،

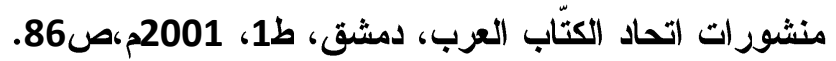

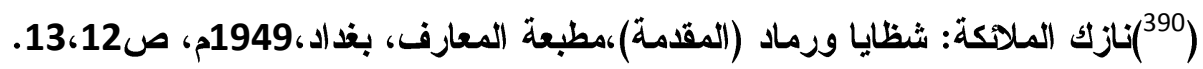
(191) نازك الملانكة: سيكولوجية الثعر ومقالات أخرى، التي دعت إلى الاكتزام بالقافيـة،

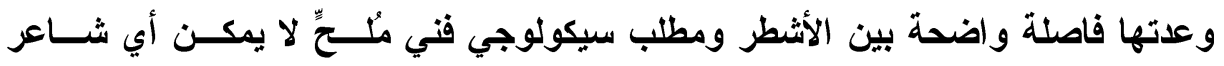

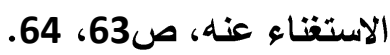

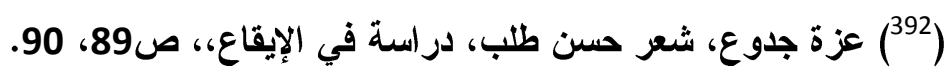

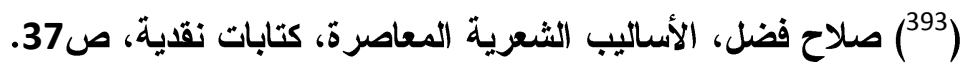
(194) يوسف نوفل، استثفاف الثعر، الشركة المصرية العالمية للنشر، لونجمان، القاهرة، 2000م، ص182. (195) إذ نجده يقول: 》إنـي أذهب إلى ضرورة الاستفادة من القافية كلما أمكـن ذلـــ؛ لأن

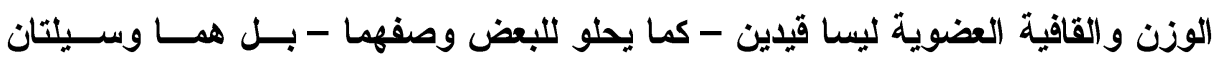
لمضاعفة زخم القصيدة، وإثراء الصلة بين الثاعر والمتلقيه نقلا عن: عناصر الإبــداع

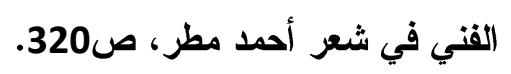

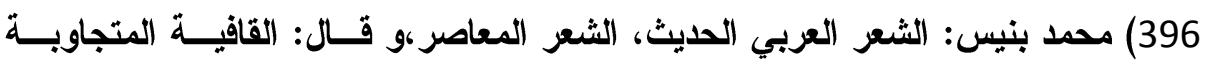
نقصد بها قانونا ثانيا أساسه تغيير مكان القافية، ج3، ص صل 144. 397) لافتات أحمد مطر: لافتة رقم 2، ص صالبال 194.

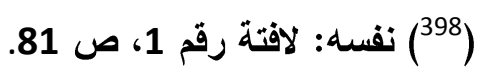

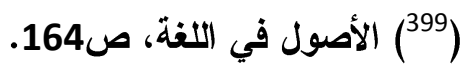

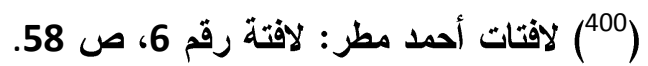

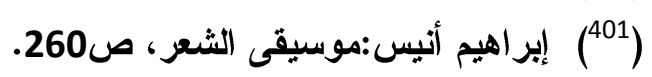

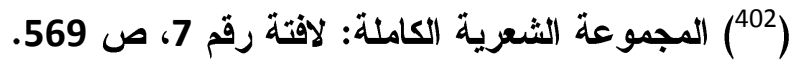

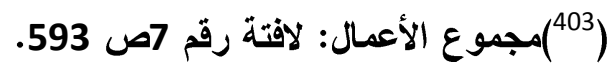

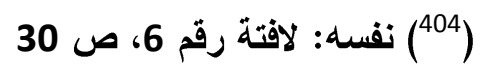
(405)ماهر هلال: جرس الألفاظ ودلاتها في البحث البلاغي والنقدي عند العرب، ص239.

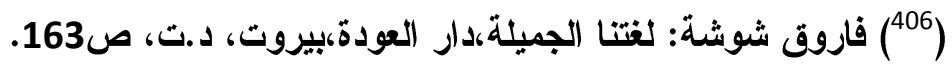


(407) علي الجارم ومصطفى أمين: البلاغة الو اضحة (البيان و المعاني و البديع)، ص249.

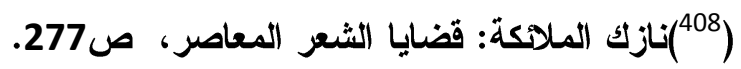

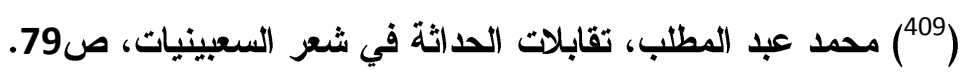

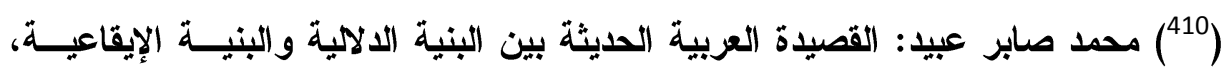
ص181، 182. 411 ) التقسيمات وأبواب التكرار اعتمدت فيها على تقسيمات موسى الربابعة: التكـــــار

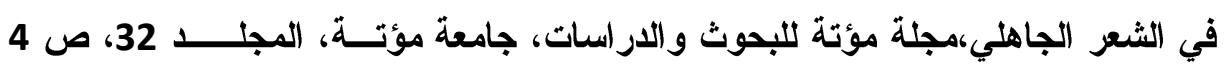
وما بعدها

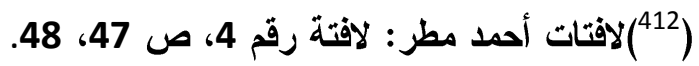

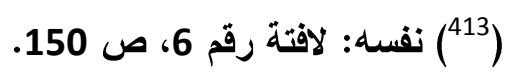

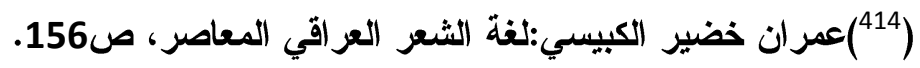

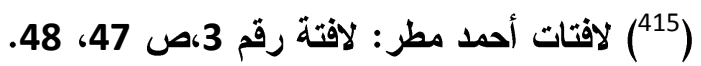

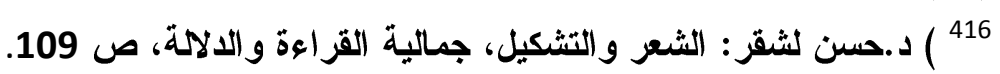

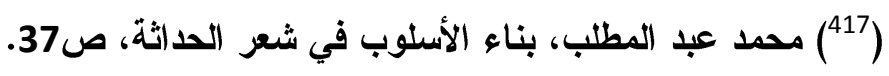
(418)

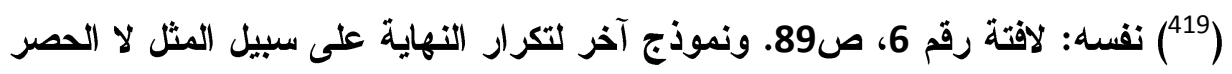

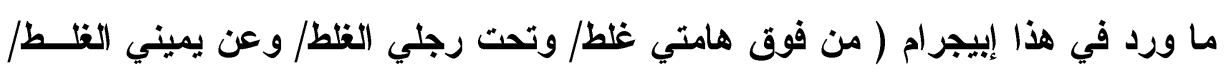

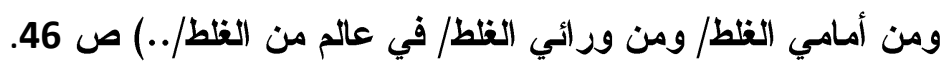

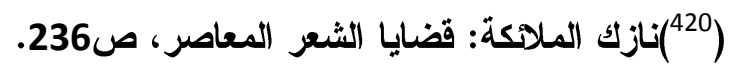

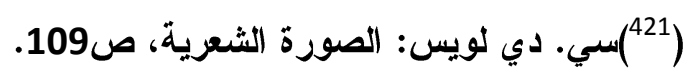

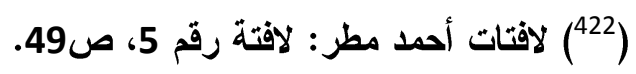

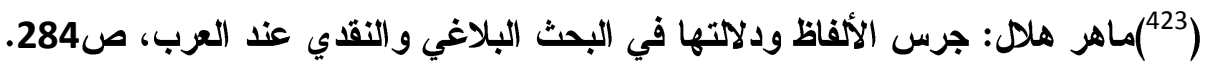

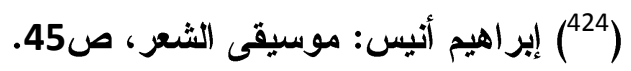

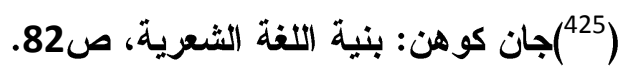

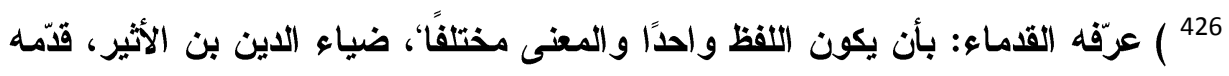

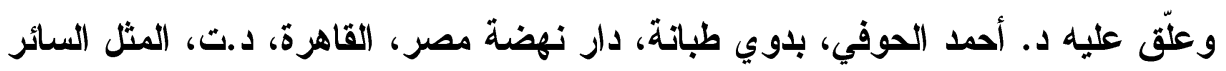


في أدب الكاتب الثاعر، ج1، ص342. 'أي أن اللفظة تصلح لمعنيين مختلفين، فــالمعنى

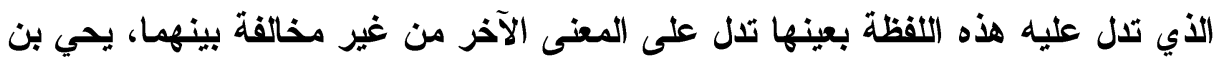

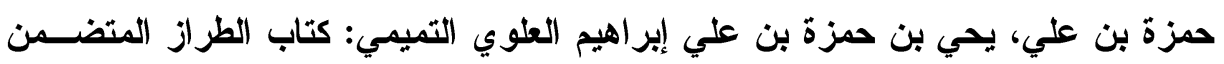

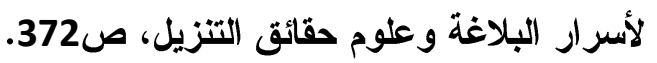

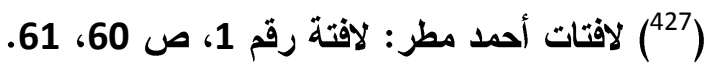

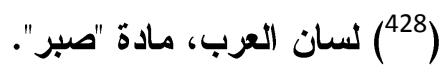

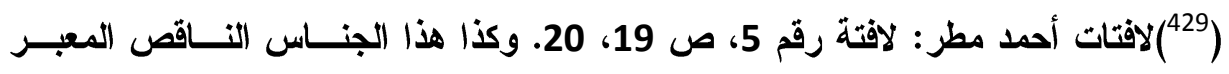

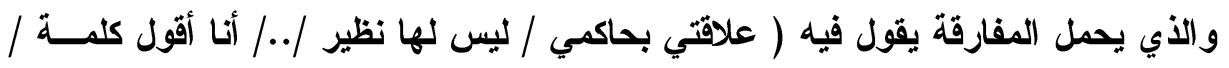

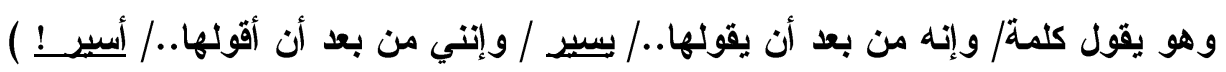

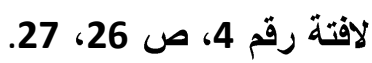

(430) القزويني: الإيضاح في علوم البلاغة (المعاني و البيان و البديع)، ص542.

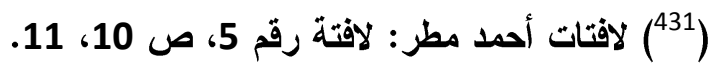

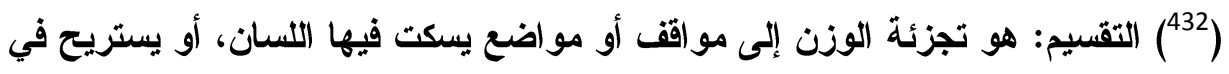
أثناء الأداء التلقائي،عبد الله الطيب المجذوب:المرشد إلى فهم أثعار العرب وصـــاعتها،

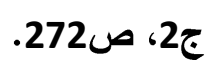

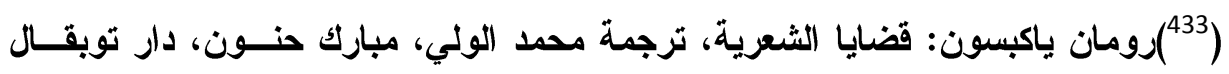

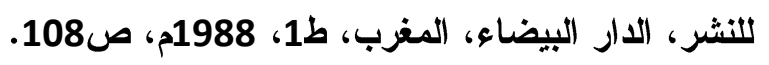

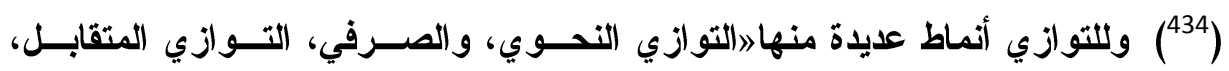

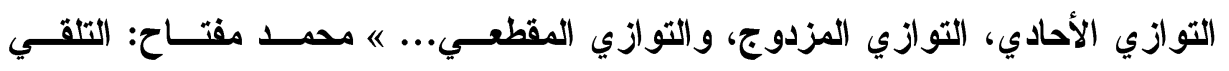

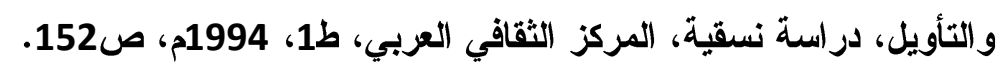

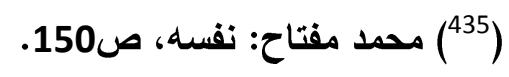

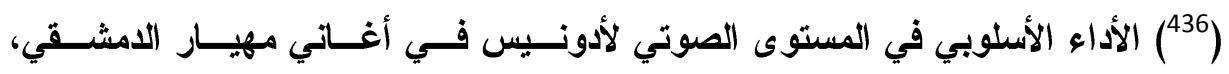
ص158.

437) اعتمدت في تقسيمات التوازي وأبوابه على ماذهب إليه د د.محمد مفتــاح: التلقــي

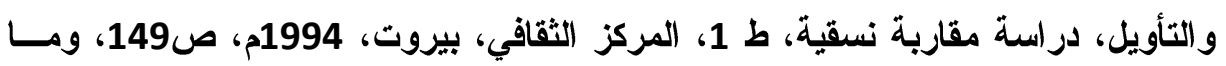




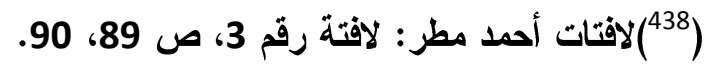

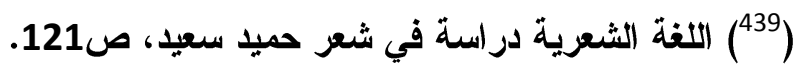

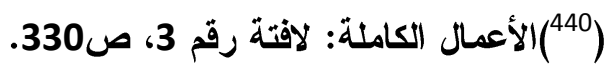

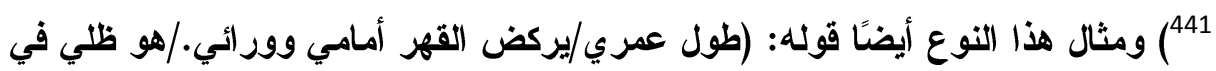

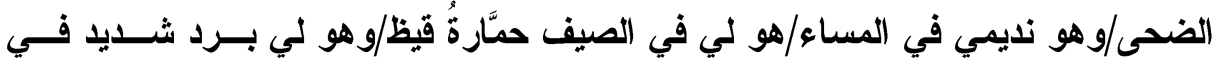

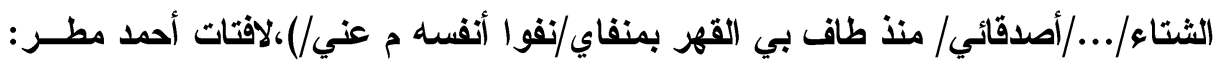

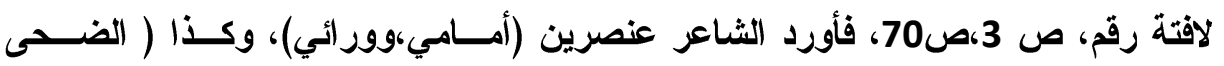

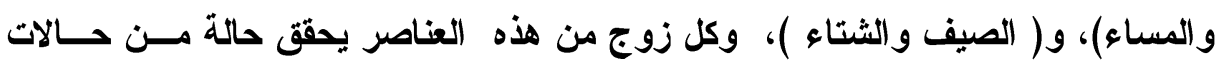

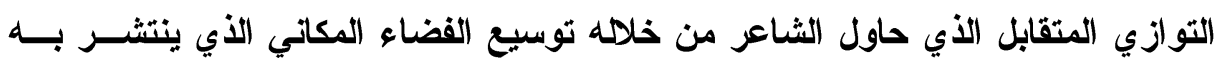

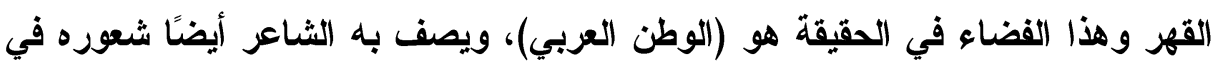
442 ) مصطفى ناصف:اللغة و التفــير والتواصـل،عالم المعرفـة،الكويت، عـدـ 193،

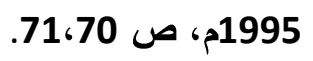




\section{المصادر و المراجع}

أو لا:المصادر

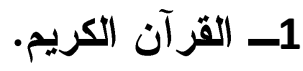

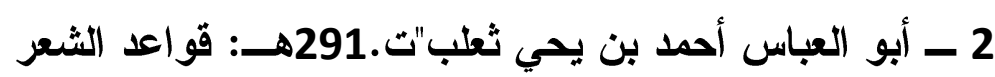

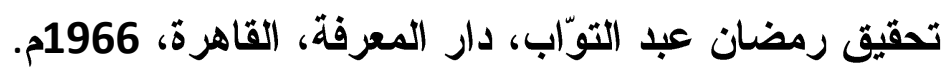

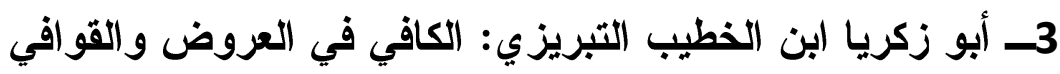
تحقيق حميد سعيد الخالصي، مطبعة شفيق،بغدي اد، 1982م

5،4 - جلال الدين محمد بن عبد الرحمن القزويني:

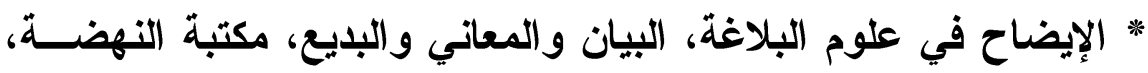

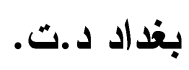

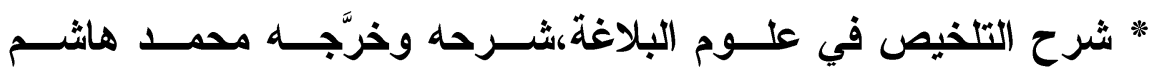

دوياري،دار الحكمة، دمثق، ط1، 1970

6ــ أبو علي الحسن بن رشيق القير اواني الأزدي "ت. 456هــ":

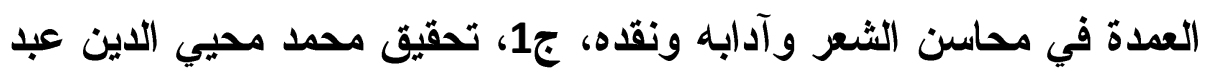

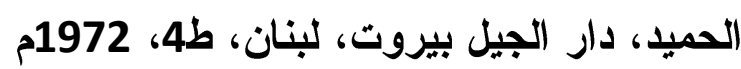

8، - 8ـ عبد القاهر الجرجاني:

* أسرار البلاغة، قرأه وعلق عليه أبو فهر محمود محمــد شــاكر ، دار المدني، القاهرة، 1993م.

* دلائل الإعجاز، تقديم محمد رشيد رضا، دار الكتاب، بيروت، لبنــان، ط1وف، 1988م 10،9- أبو الفتح عثمان بن جني: * الخصائص، تحقيق محمد علي النجار، الهيئة المصرية للكتاب، 1999م

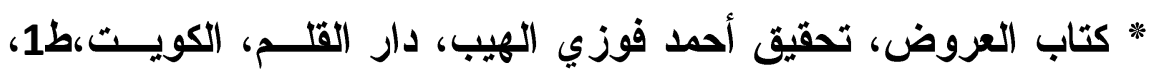




\section{7}

11ــ أبو هلال العكري: كتاب الصناعتين تحقيق:علي البيجاوي،ومحمد أبو الفضل إبراهيم،مكتبة الحلبي، القاهرة، 1952م. 12- أبو الحسن علي بن عيسى الرّماني النحـــوي " ث.384هـــــ": معــــي

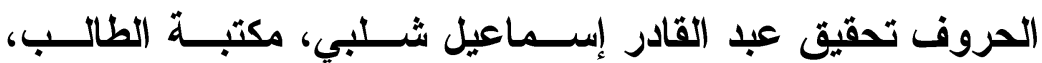

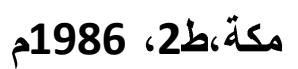

13ــ أبو فرج قدامة بن جعفر"ت. 337 هـ ": نقد الثعرتحقيق محمد عبد المنعم خفاجي، دار الكتب العلمية، بيروت، لبنان د.ت.

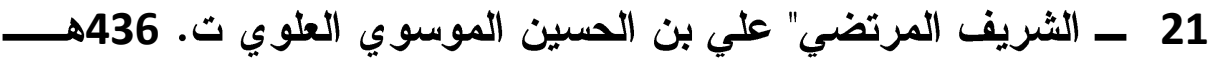

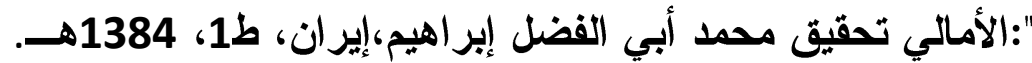
14 - يحي بن حمزة بن علي العلوي التيمي: كتــاب الطـــراز المتضـــن لأسرار البلاغة تحقيق محمد عبد السلام شاهين، بيروت، لبنــان،

$$
\text { ط1 ن 1995م }
$$

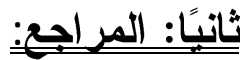

[1]: المراجع العريية: 16،15- إبر اهيم أنيس: *من أسرار اللغة، مكتبة الأنجلو المصرية، ط7، الهب، 1985م.

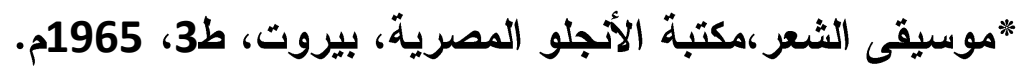

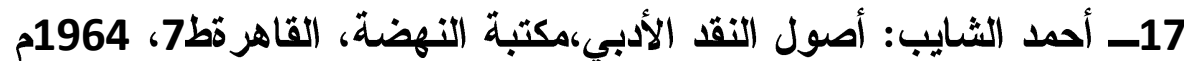
18ــ أحمد الصغير المراغي: بناء قصيدة الإبيجرامـا فــي الثــعر العربــي الحديث،الهيئة المصرية العامة للكتاب ن 2012م 


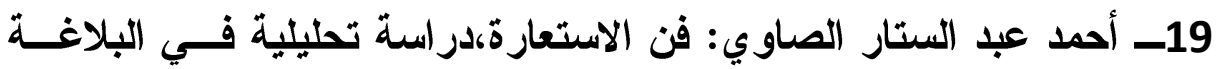

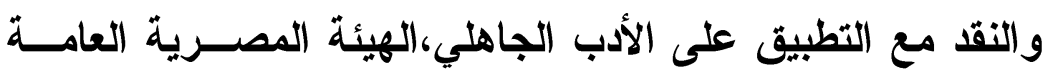

$$
\begin{aligned}
& \text { للكتاب،الإسكندرية، 1979م. } \\
& \text { 21،20- أحمد مطر : }
\end{aligned}
$$

الأعمال الكاملة، إعداد وتقديم حازم النجار، المصــرية للنشـر والتوزيــع،

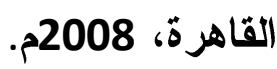

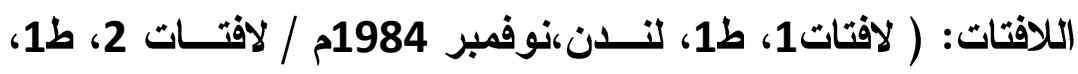

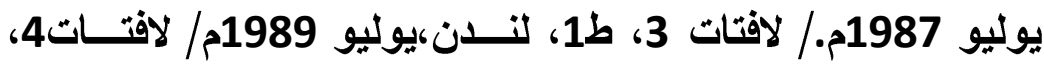

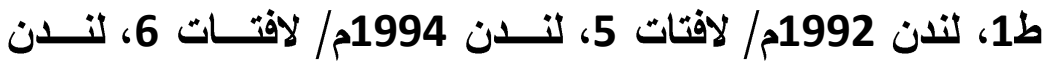

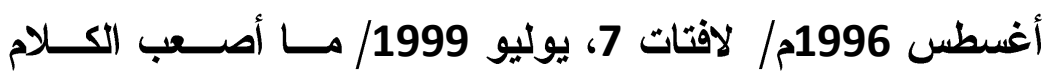
(قصيدة إلى ناجي العلي)، 1987م./ ديوان: إني المشنوق أعلاه،

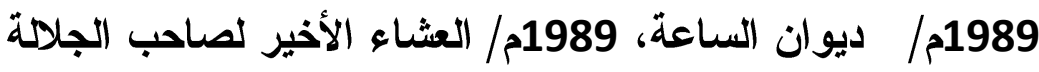

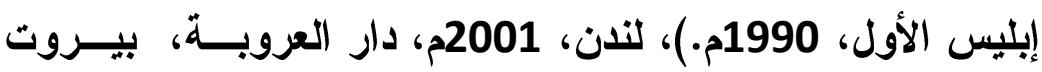
2011

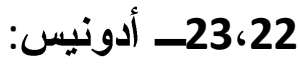
ــ الأعمال الثعرية الكاملة، الهيئة العامة لقصور الثقافــة، القــاهرة، 2006 - ـ زمن الثعر، دار العودة،بيروت، 1972م. 24،23- بشرى موسى صالح: * الصورة الثعرية في النقد الأدبي الحديث، المركز الثقافي العربي، بيروت، 1994م * نظرية التلقي أصول وتطبيقات، دار الثؤون العامة، بغداد،1999م. 
25ــ جابر عصفور: الصورة القنية فـــي التــراث النقـــي والبلاغـي، دار المعارف، القاهرة، 1974م.

26 ـ جهاد فاضل: قضايا الثــعر الحــديث، دار الثـــروق، بيـروت، ط1، 1984

27ـــ حسن لشقر : الثعر والتشكيل، جمالية القراعة و الالالة،مطبعـة آنفــو براتت،فاس، المغرب، ط1، 2012م. 29،28ـ حسين خمري: * الظاهرة الثعرية العربية الحضور والغياب، اتحاد الكُتاب العرب،ســوريا، .2001

30ـ رشيد يحياوي: مقدمات في نظرية الأنواع الأدبية،أفريقيا الثرق، الدار

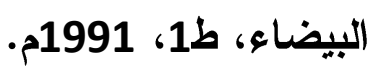

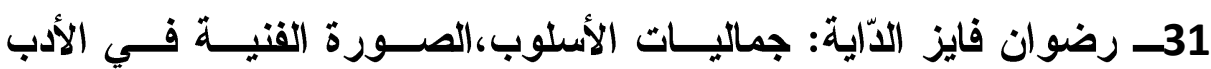

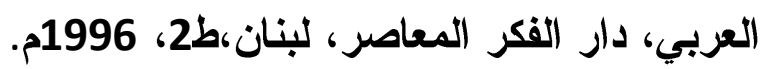

32- سعيد علوش: معجم المصطلحات الأدبية المعاصرة.تقديم وترجمــة،دار دار الكتاب اللبناني،بيروت، سوشبريس، الدار البيضاء،ط1، 1985م

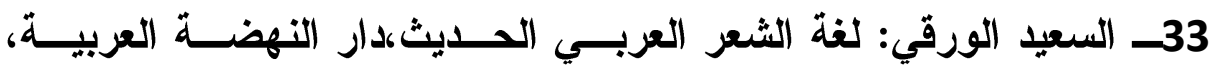
بيزوت، ط3، 1984م.

34 - شكري الطوانسي: مستوى البناء الثعري عند محمد إبراهيم أبي سنة ، الهيئة المصرية العامة للكتاب، 1999م.

35ـ صالح بلعيد:التراكيب النحوية وسياقاتها المختلفة عند الإمام عبد القاهر الجرجاني،ديوان المطبوعات الجامعية،ط1، 1994م. 
36ـ صفاء خلوصي: فن التقطيع الثعري والقافية،مكتبة المثنى، بغداد،5، 1977

37- صلاح فضل: علم الأسلوب ،دار الشروق، بيروت، ط1، 1998م.

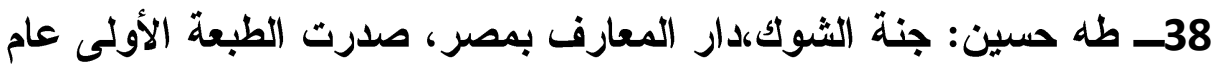

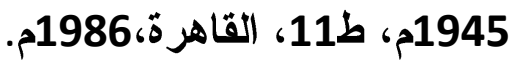

39- عبد الرّضاعلي:العروض والقافية،دراسة وتطبيق في شعر الثــطرين و الثعر الحر،دار الكتب للطباعة والنشر، الموصل، 1989م

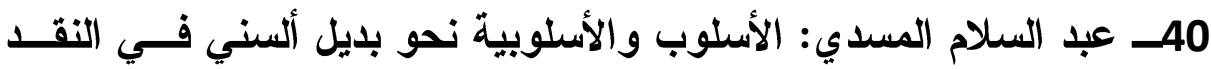

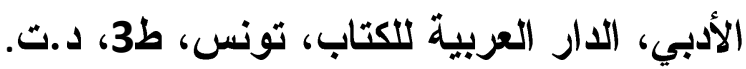

41 1988

42ـــــ عبد القادر فيدوح: الاتجاه النفسي في نقد الثُعر العربــي، منشــورات

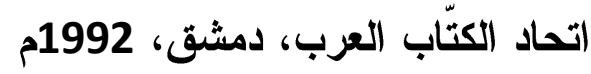
43، 44، 45 عـ عز الاين إسماعيل:

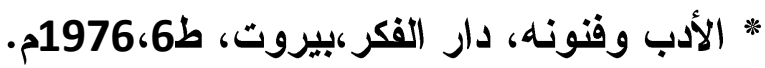

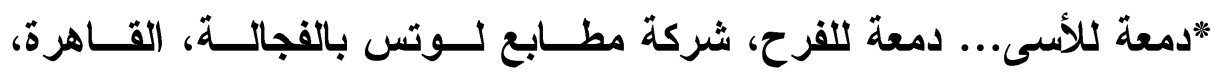
2000

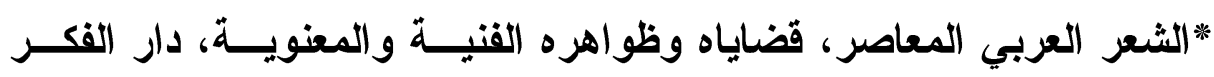

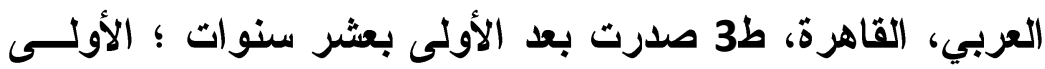
1966 م.

47،46ـ عز الدين المناصرة:

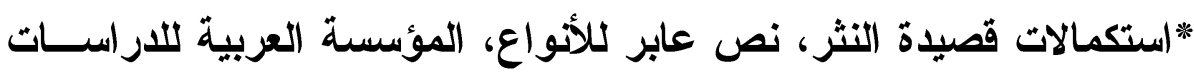
والنشر، بيروت، لبنان، ط2، 2002م. 
*علم الثعريات قراعة مونتاجية في أدبية الأدب، دار مجلاوي، عمان، ط1، 2007

48ـ عزوز علي اسماعيل: شعرية الفضاء الروائي عند جمال الغيطاني،دار

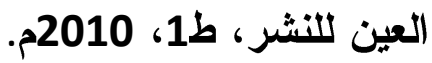

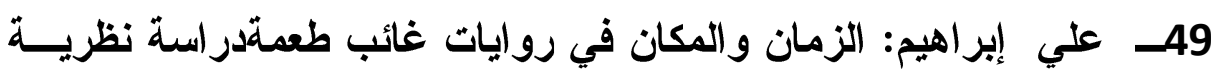

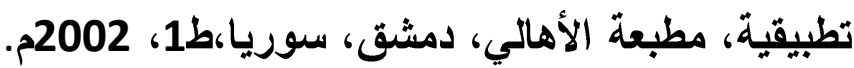

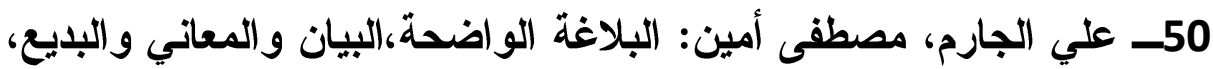

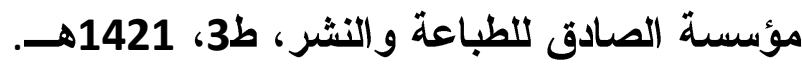

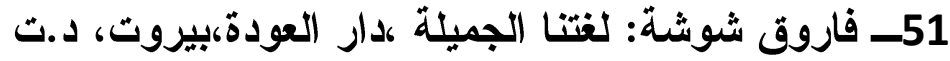

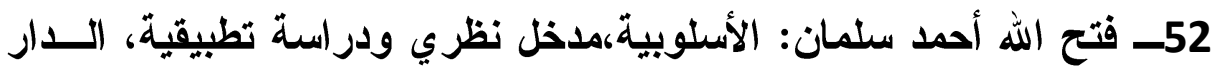

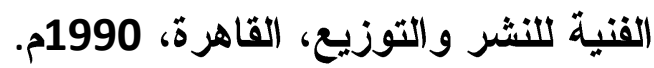

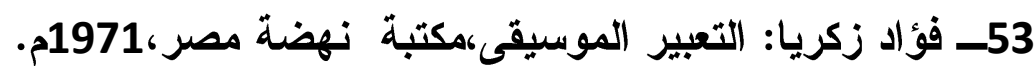

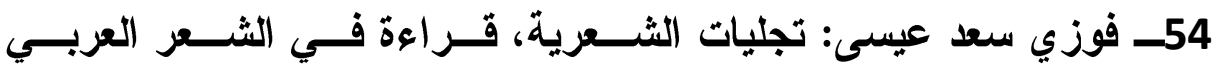

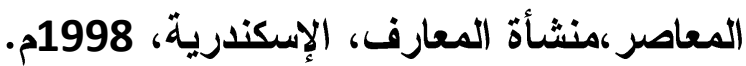

55ـ كاظم جهاد: أدونيس منتحلا، دراسة في الاستحواذ الأدبي وارتجاليــة

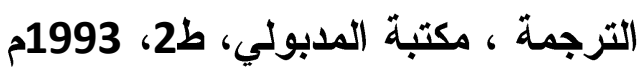

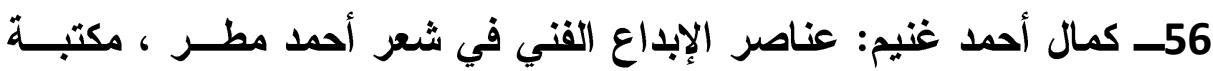

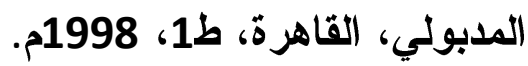

57ــ ماهر مهاي هلال: جرس الألفاظ ودلالتها في البحث البلاغي والنقدي

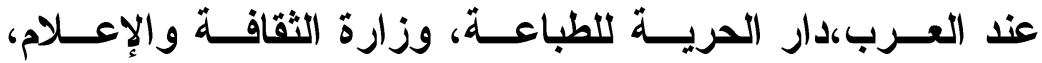
بغد (د،د .ت. 58 محمد بركات حمدي أبو علي:البلاغة العربية فـي ضــوء الأســلوبية 
ونظرية السياق،دار وائل، عمّان، الأردن، ط1،2001م

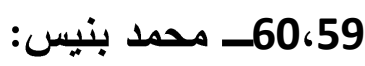

*الثعر العربي الحديث، الثعر المعاصر، ج3، دار توبقــال للنشــر، الـــار البيضاء، المغرب، ط2، 1996م

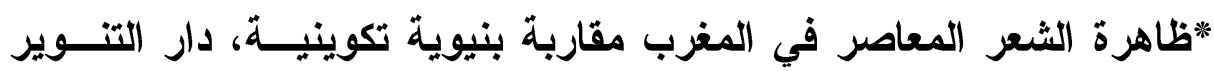

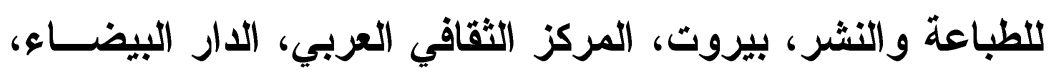
ط2، 1985م.

61ــ محمد حمدي إبراهيم: الأدب السكندري،دار الثقافة للنشر، القاهرة،ط1، 1985

62ــ محمد رضا مباركك: اللغة الثعرية في الخطاب النقدي العربي ؛ تـلازم

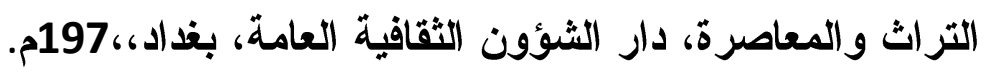

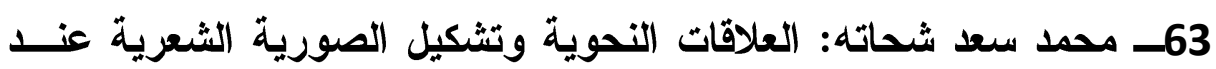
محمد عفيفي مطر، الهيئة العامة لقصور الثقافة، 2003م

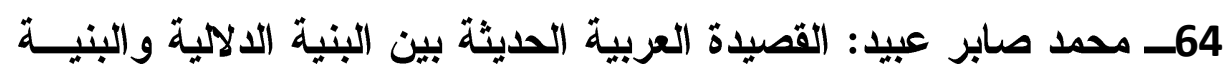

$$
\text { الإيقاعية }
$$

منشورات اتحاد الكتّاب العرب، دمشث، ط1، 1661، 2001م. 66،65، 68،67، 71،70،69، 72- محمد عبد المطلب: "البلاغة قراعة أخرى، الشركة المصرية العالمية للنشر، لونجمان، القاهرة، ط1، 1995م.

*بناء الأسلوب في شعر الحداثة، دار المعارف، ط1، القاهرة، 1988م.

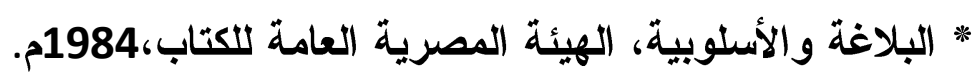

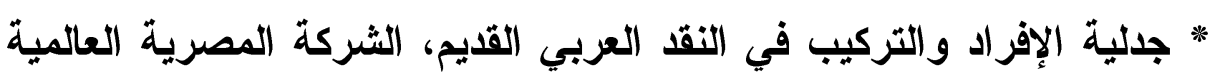
للنشر، لونجمان،ط1 القاهرة، 1995م. 
* " شعر اء السبعينيات وفوضاهم الخلاّقة، سلسلة العلوم الاجتماعية، مكتبــة

$$
\text { الأسرة، 2009م }
$$

*ضايا الحداثة عند عبد القاهر الجرجاني، الثركة المصرية العالمية للنشر،

$$
\text { لونجمان، القاهرة، 1995م. }
$$

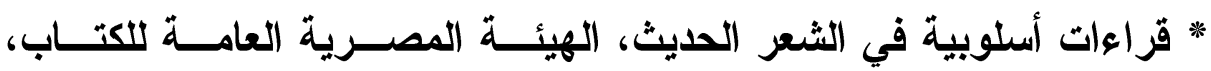
1995

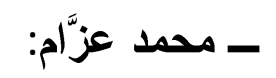

* مصطلحات نقدية من التراث الأدبي العربــي، منشــورات وزارة الثقافــة،

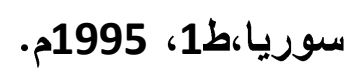

73ـ محمد فؤاد السلطان: دراسة الغضب والتمرد في شعر أحمد مطر ،مجلة

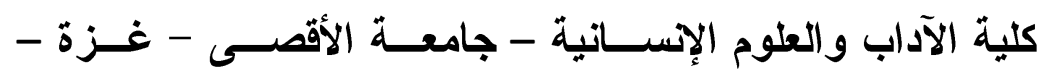

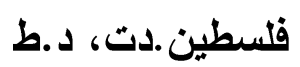

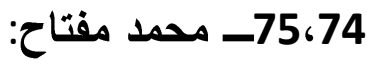

*التلقي والتأويل، دراسة نسقية، المركز الثقافي العربي، ط1، 1994م

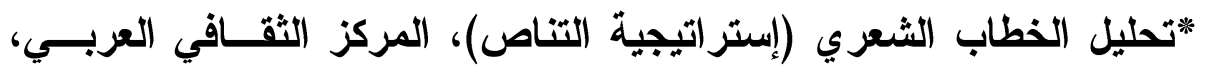

$$
\text { الارار البيضاء، المغرب، 1985م. }
$$

76- محمد مندور: الأدب وفنونه،مكتبة نهضة مصر، 1996م.

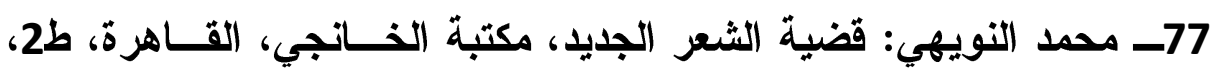
1971

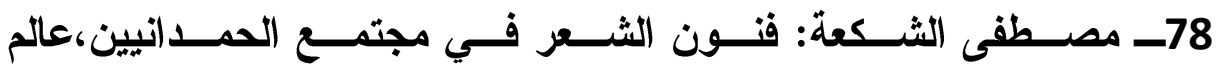

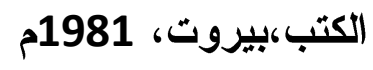

80،79ـ مصطفى ناصف: 
*الصورة الأدبية، دار مصر للطباعة، القاهرة، ط1، 1958م.

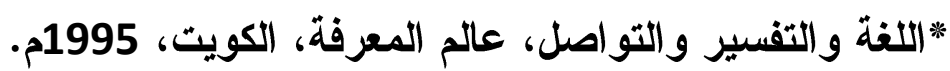

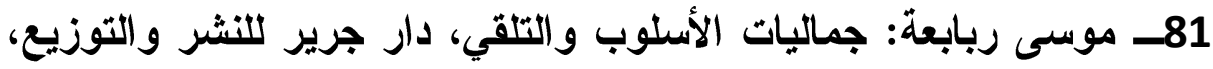

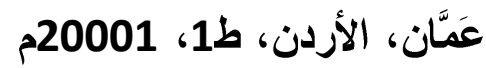

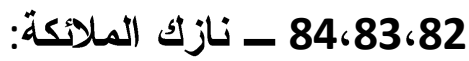
*سيكولوجية الثعر ومقالات أخرى، دار الثؤون الثقافية، بغداد، العراق، 1993

* شظايا ورماد (المقدمة)،مطبعة المعارف، بغداد، 1949م

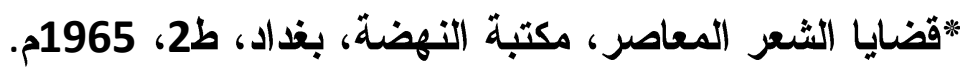
87،86،85 - يوسف نوفل:

*استثفاف الثعر، الثركة المصرية العالمية للنشر، لونجمان، 2000م.

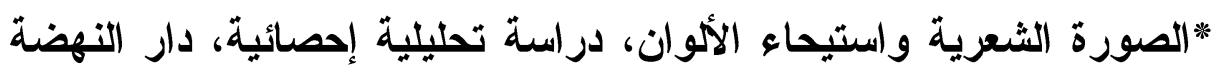
العربية للطباعة، 1985م.

*طائر الثعر، عش الفيض.. فضاء التأويل،، الهيئة العامة لقصور الثقافــة،

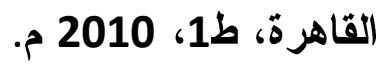
[2][المراجع الأجنبية المترجمة: 88ــــ آن مورال: من جاتب الأثر الإبداعي،النقد البنيوي. ترجمة بريهمــات

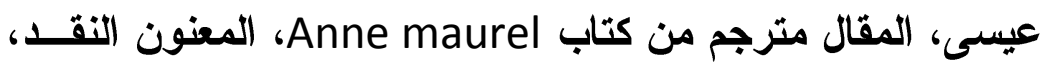

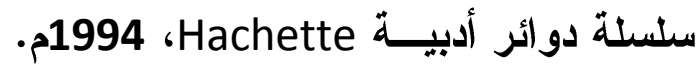
89ـــ أرشا بالد مالكش: الثعر والتجربة. ترجمة سلمى الخضر اءع الجيوسي،

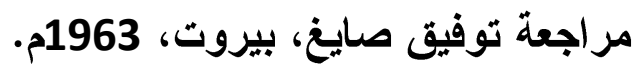

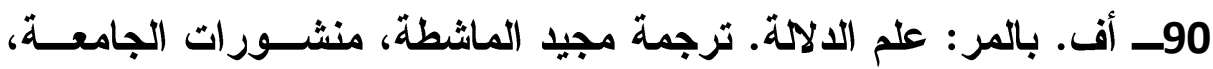
بغد اد، 1981م. 
91ـــأوين كرزويل: عصر البنيوية من ليفي شتراوس إلى فوكــو. ترجمــة

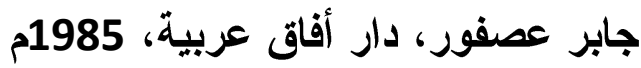

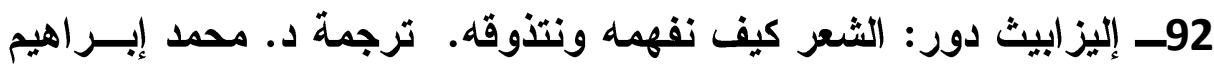
الثوش، بيروت، لبنان، 1961م.

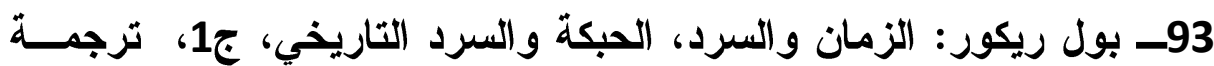

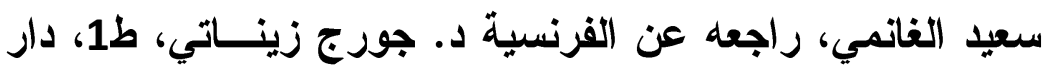

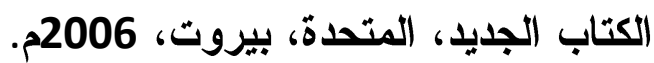

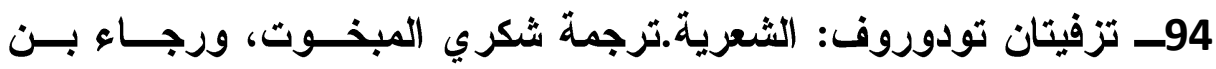
سلامة،، دار توبقال للنشر، المغرب، 1987م.

95ـ جاكك شورون: الموت في الفكر الغربي ترجمة كامل يوسـف حســن، مطبعة الرسالة، الكويت، 1984م

96ـ جاكوب كورك: اللفة في الأدب الحديث، الحداثة والتّريب ترجمة ليون

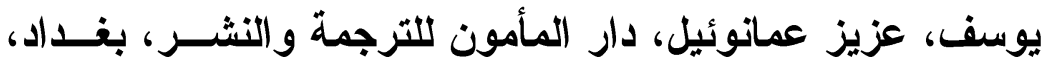
1989م.

97ـ جوليا كريستيفا: علم النص ترجمة فريد الزاهي، دار توبقــال للنشـر، الارار البيضاء، المغرب، ط1، 1982م.

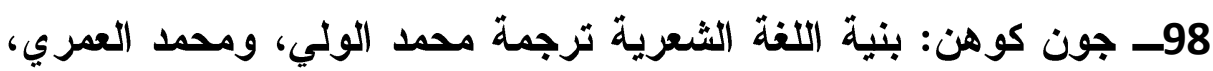

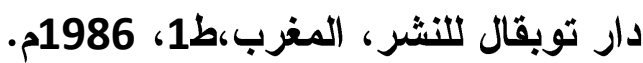

99ــ دي. سي.ميونك: موسوعة المصطلح النقدي (المفارقة) ترجمة عبـــ

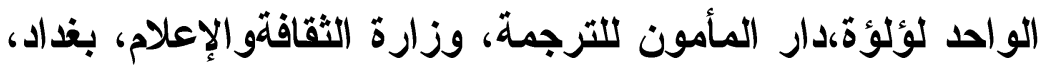
1982 
100ــ ديفيد بثنبدر: نظرية الأدب المعاصر وقراء ة الثــعرترجمة، عبـــ

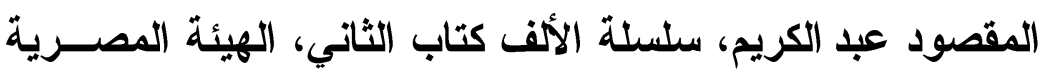

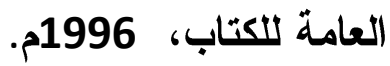

101- رومان ياكبسون: قضايا الثعرية ترجمة محمد الولي،مبارك حنـــون، دار توبقال، الدار البيضاء، المغرب، ط1، بهن، 1988م

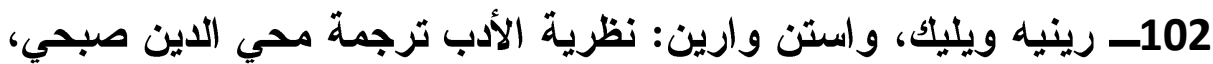

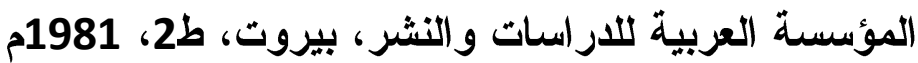

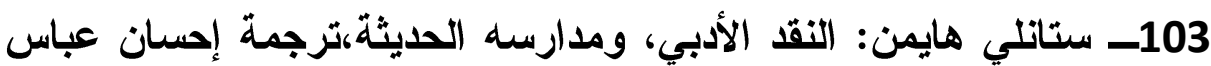
ومحمد يوسف نجم، دار الفكر العربي، القاهرة، د.ت، ج.

104 - سي دي لويس: الصورة الشعرية،ترجمة أحمد نصــيف وآخـرين،

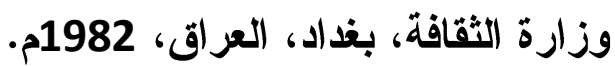

105- سي.موريه: حركات التجديد في موسيقى الشعر العربي، ترجمة سعيد

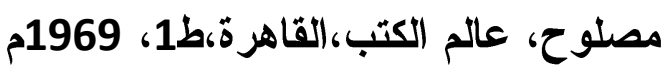

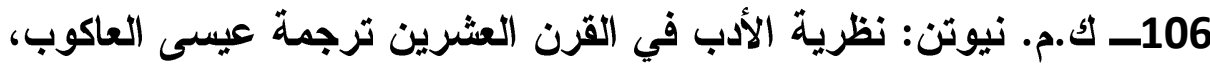

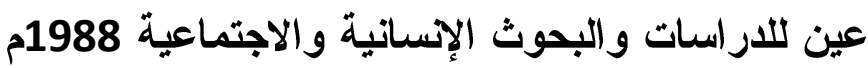

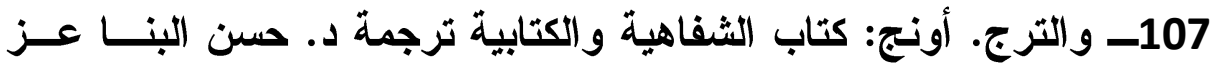

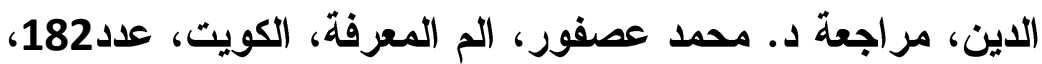

$$
\text { فبر اير 1994م }
$$

108- هانز ميرهوف: الزمن في الأدب .ترجـــة أســـد رزوق، مؤسســـة فر انكلين للطباعة والنشر، القاهرة، نيويوريك، 1972م.

[3] [المراجع الأجنيبة غير المترجمة:

109- The new Enseclopaedia Britorinca, Micropedia volume 11115 th Edition, Helen Hemingway Benton Publisher, 1973.

110-Hudson, H.H. The Epigram in the English Renaissance Princton, University Press, New Jersy, 1947. 
بنية قصيدة الإبيجرام في لافتات أحمد مطرد. أسماء محمود شمس الدين

111-Mohammadi, H. time in the widerness, trams Adintro, by M. Enani, General Egyption Book Organization Cairo.

112- Studien zum Griecluischen Epigramm, Neue Fur das klassische Alter tum, 1917.

113-Roman selden: The theory of Criticism From, Plato the Present, press, 19. 114-Ralph Cohen, Hosory and Genre, New Literary,N: Winter 1983.

(115-Udson,H.H,The Epigrama in The English Renaissan, Princeton,University Press,New Jersey. U.S.A,1947

116-Herausge ge Ben Von Otto Kno"rrich:Former der Literatur in Einzel Dar Stellungen, Epigram, Alfred Kro"ner Verlag( STUTTGART), 1981

117-Book Litle: Buch Von Der (Deutschen) Poeterey,Author; Martin Opitz , Max Niemeyer Verlag, TUBINGEN, 1966

ثنالثًا: الدوريات الثقافية

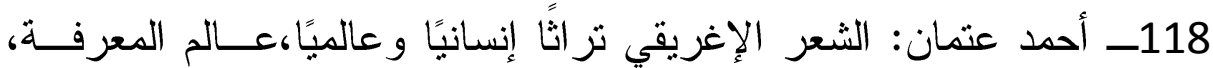
الكويت، ط1، العدد 1984، 1987م.

119-ـ د. ريكان إبر اهيم: الأسس النفسية للتجريب الشعري، مجلة أقلام، عدد 11، بغداد، 1989م.

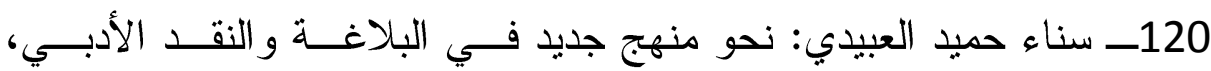
منشور ات جامعة قاريونس، بني غازي، ط1، 1998م. 121، 122- صلاح فضل:

*أساليب الشعرية العربية المعاصرة،سلسلة كتابــات نقديــة، ع (54)،الهيئـة العامة لقصور الثقافة، 1996م.

*بلاغة الخطاب و علم النّص، سلسلة عالم المعرفــة، عــدد 164، الكويــــ، •1992

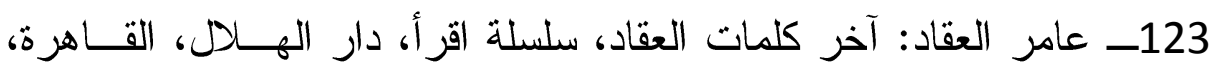
•1966

124- عبد الغفــار مكــاوي: قصــيدة وصورةالثــعر و التصـــوير عبــر العصور ،سلسلة عالم المعرفة،عدد 119، 1987م. 
125ــخري قسطندي: مجلة فصول عدد خاص عـن الأدب المقارن،عـدد

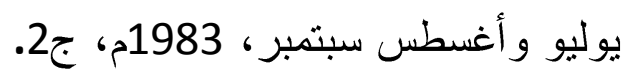

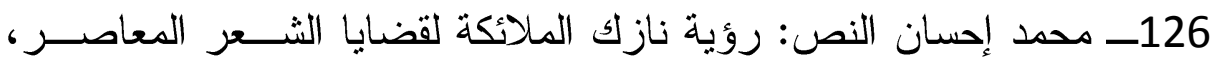

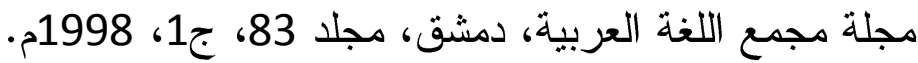

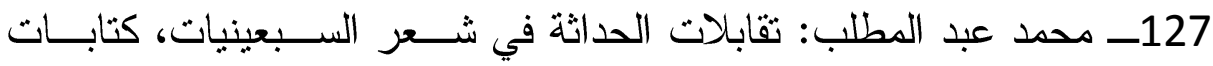
نقدية، ع(45)، الهيئة العامة لقصور الثقافة، القاهرة، 1995م.

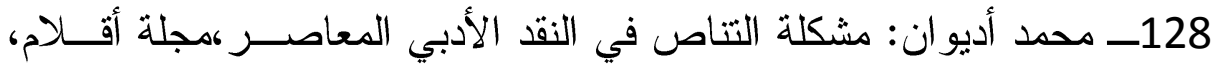
العدد 6.

129- محمد الهادي الطر ابلسي: في مفهوم الإيقاع،حوليات الجامعة التونسية

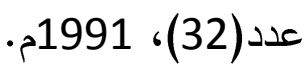

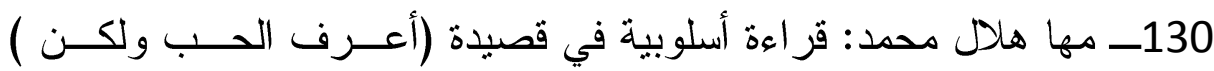

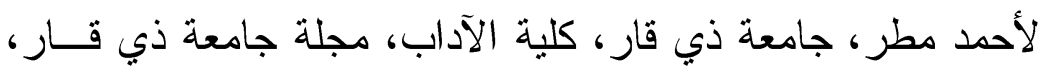
عدد خاص، مجلد5، 2010م. 131- يوسف نوفل: *النص الكلي، سلسلة كتابات نقدية(124)، الهيئة العامــة لقصــور الثقافــة،

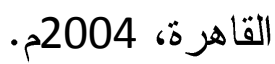




\section{محتوى البحث}

ملخص البحث باللغة العربية

ملخص البحث باللغة الإنجليزية

مقدمة:

تمهيد:الثاعر أحمد مطر:

أو لاً: إطلالة على فن الإبيجر امثد في الآداب العالمية قديمها وحديثها:

ثانيًا: بنية قصيدة الإبيجر ام في اللافتات:

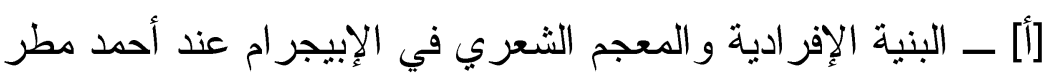

1 ـ مفردات السياسة، و الرَّفض، و الثجن:

2

3 ـ مفردة الموت ومر ادفاتها:

4- مفردات المكان:

5 ــ المفردات العامية و الأجنبية:

[ب] بلاغة التر اكيب في الإبيجر ام عند أحمد مطر:

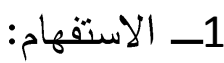

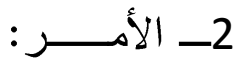

3

4

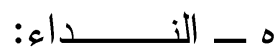

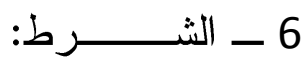

7 - التقديم و التأخير :

8 - 8 
[ج] الدلالة وأدوات الصورة الشعرية:

1 التشبي.

2 - الاستعارة:

3

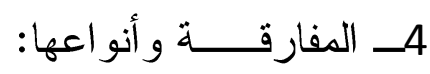

أنو اع المفارقة: - مارة

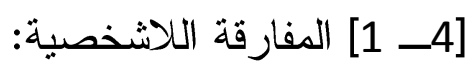

[4- 2] مفارقة الاستخفاف بالذات:

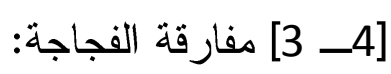

[4- 4 4 المفارقة الدر امية:

5 - تجليات التّاص و أنو اعه ومصسادره:

ومن تجليات التتاص في إبيجر امات أحمد مطر :

[-5 1 1 ] تناص الاجترار:

[5- 2 2] تناص الامتصاص:

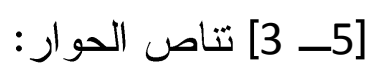

أميز المصادر التي تتاص الثاعر معها:

[ 5 - 5 أ] القرآن الكريم:

[5 - [ ب] الثَّعر العربي:

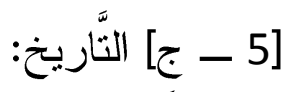

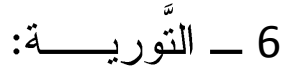

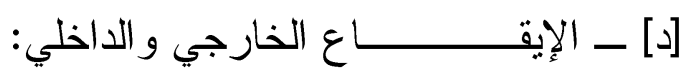

د - أو لاً: الموسيقى الخارجية

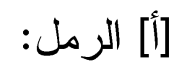




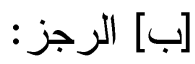

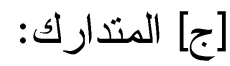

$$
\begin{aligned}
& \text { د ــ ثانيًا:الموسيقى الداخلية } \\
& \text { [أ ] القافية: } \\
& \text { [أ - 1 1 ] القافية المتجاوبة: } \\
& \text { [أ ـ 2 2] القافية المزدوجة: } \\
& \text { [أ ـ 3 3] القافية المتعددة: } \\
& \text { [ب] التكر ار: }
\end{aligned}
$$

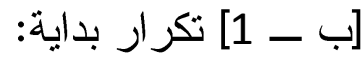

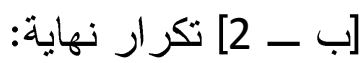

$$
\begin{aligned}
& \text { [ب -3] تكرار جملة: } \\
& \text { [ج ] التَّنيس: } \\
& \text { [ج - 1 1 ] الجناس التام: } \\
& \text { [ج - 2 ] الجناس الناقص: } \\
& \text { [ج -3] الجناس الاشتقاقي: }
\end{aligned}
$$

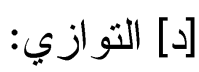

$$
\begin{aligned}
& \text { [د ـ د ـ 1 1 التوازي النحوي و الصرفي: } \\
& \text { [ـ ـ ـ ـ ـ 2 التو ازي المتقابل: } \\
& \text { ـ خاتمة البحث و النتائج } \\
& \text { ـ ثبت المصادر و المر اجع }
\end{aligned}
$$

